I. S. GHOLGHCLL ST RVEY OF THE TERRTTORIES

F. S. HA Y DES INCHARGE

VII

WTIIOGRAPHIY AND PIIILOLOGY () $F$

TIIE IIIDATSA INDIANS

MA T T HE W S

1877 

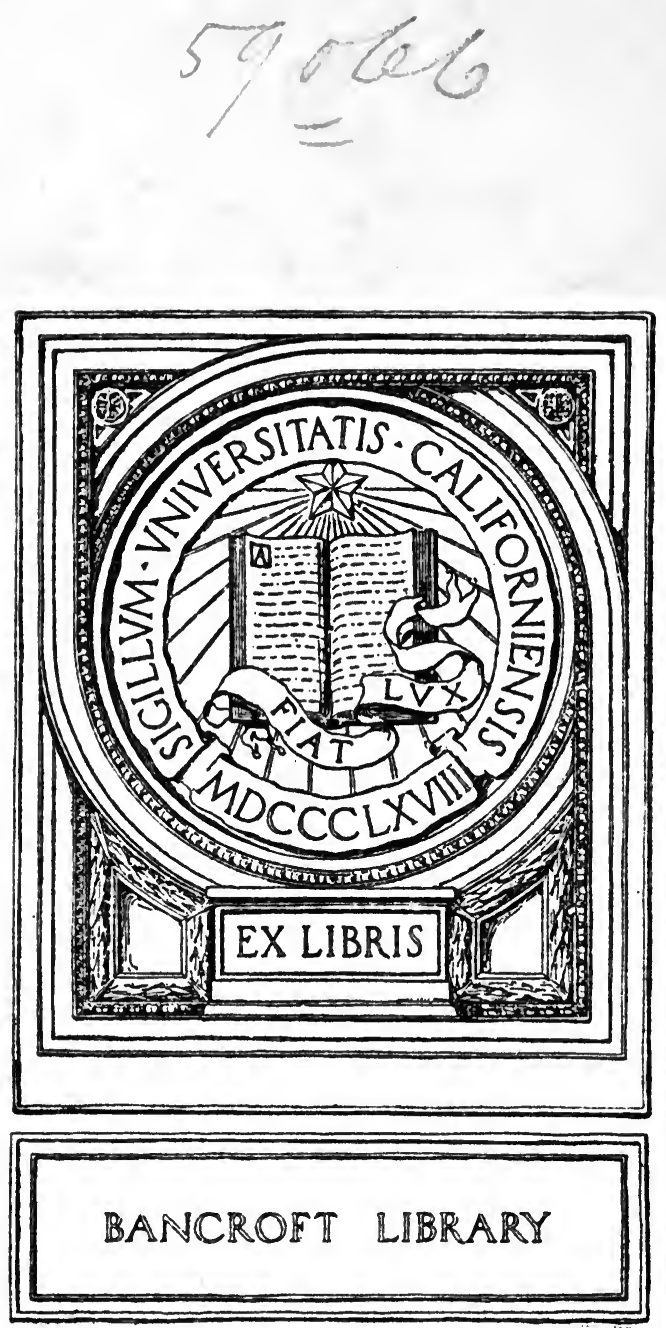



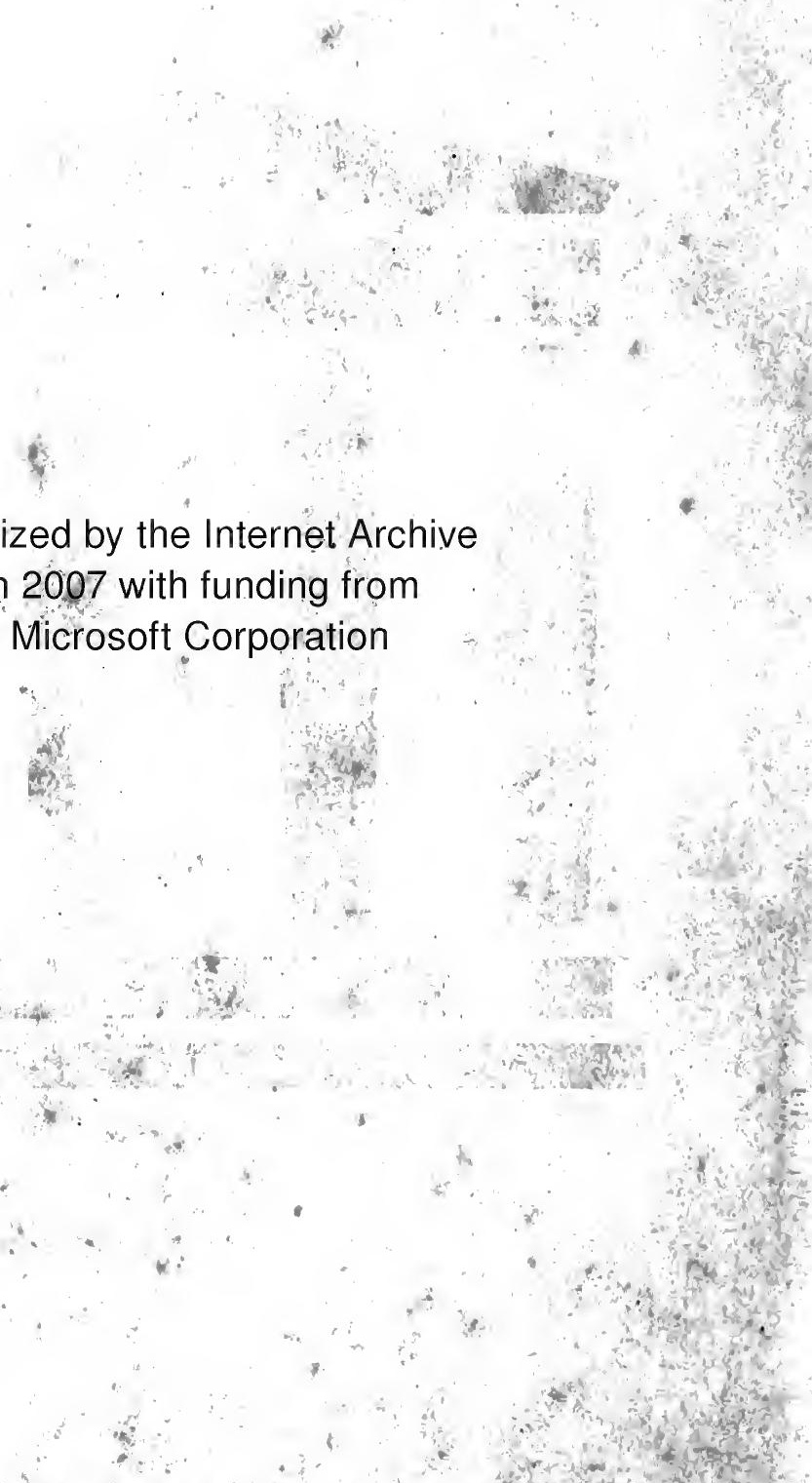

Digitized by the Internet Archive in 2007 with funding from 1. Microsoft Corporation 


DEPARTMENT OF THE INTERIOR. UNITED STATES GEOLOGICAL AND GEOGRAPHICAL SURVEY. •

F. V. HAYDEN, U. S. Geologist-IN-Charge.

MISCELLANEOUS PUBLICATIONS.-No. 7.

\section{ETHNOGRAPHY AND PHILOLOGY}

OF TIIE

\section{HIDATSA INDIANS.}

BY

WASHINGTON MATTHEWS,

ASSISTANT SURGEON UNITED STATES ARMY.

WASH I N G TON:

GOVERNMENT PRINTING OFFIOE.

1877 . 
E99 


\section{PREFATORY NOTE.}

\section{Unived States Geological and \\ Geographical Survey of the Territories, Washington, D. C., June 10, 1877.}

During the year 1854, while engaged in exploring the then almost unknown country along the Upper Missouri and its tributaries, the writer of this note commenced the work of collecting vocabularies of the languages and other ethnological data respecting the Indians of the Northwest. He continued this work at intervals during a period of about six years, and the materials thus accumulated were finally published in 1562 in the "Transactions" of the American Philosophical Society of Philadelphia, under the title of "Contributions to the Ethnography and Philology of the Indian Tribes of the Missouri Valley". A brief sketeh of the Hidatsa Indians, and an incomplete vocabulary of their language, was included in that work.

The author of the present volume, Dr. Washington Matthers, assistant surgeon United States Army, spent some years among these Indians while stationed at a military post in performance of his official duties as a medical officer of the Army. During this period he paid great attention to the same subject, observing the manners, customs, and other characteristics of these Indians, and making a close and careful study of their language. In this way were secured the materials upon which, elaborated with the utmost care and with conspicuous ability, the present important memoir is based.

Dr. Matthews's earlier studies of the subject resulted in a HirlatsaEnglish and Euglish.Hidatsa vocabulary, prefaced by an essay on the grammatical structure of the language. A small edition (100 copies) was printed by Mr. J. G. Shea as one of his series of American Linguistics. At the request of the writer, - who earnestly desired to push to completion the work he had long since undertaken, but was compelled by pressure of other engagements to suspend,-Dr. Matthers spent much time in entirely remodeling and greatly enlarging the scope of his paper, to include the ethnography as well as the philology of the tribe. His final result is herewith presented.

Besides revising and adding much new matter to the vocabularies, Dr. Matthews has here made those other important additions, without which the article could hardly have been considered monographic. The whole of the "ethnography" and "philology" are new. The manner in which the work has been accomplished reflects great credit upon the author and upon the Hedical corps of the Army, whose capacity for scientific work Dr. Matthews honorably illustrates in his own person. Of the ralue of the work as a contribution to American Ethnology, little need 
be said; I regard it as the most important memoir on our aboriginal Indian languages which has appeared since the Dakota grammar and dictionary, by Rev. S. R. Riggs, was published by the Smithsonian Institution.

It was originally intended to publish this treatise as a portion of a general work on Indian ethnography now in course of preparation by the undersigned. The delay in its appearance which such course would entail, and the great merit of the work here accomplished, render it desirable, in justice both to the author and to the subject, that it should appear as a separate publication.

As circumstances rendered it impossible for the author to attend per. sonally to the work during its. passage through the press, the duty of superintending its publication devolved upon Dr. Elliott Coues, U. S. A., to whom the thanks of the Survey are due for the careful manner in which he has accomplished the task.

F. V. HAYDEN, United States Geologist. 


\section{TABLE OF CONTENTS.}

\section{ETHNOGRAPHY.}

\section{Part I.}

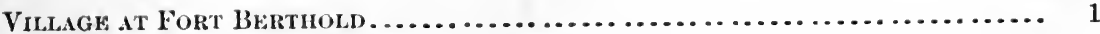

Location .............................................. 1

Dwellings ................................................ 1

. Drying frames .............................................. 8

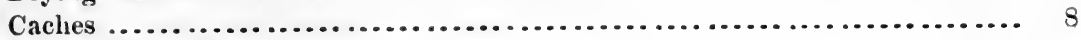

Cemetery ; burial ............................................ 9

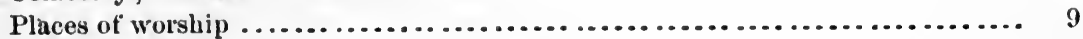

Fortifications ............................................... 10

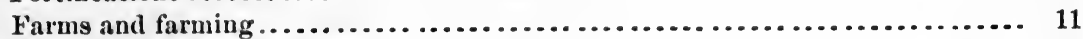

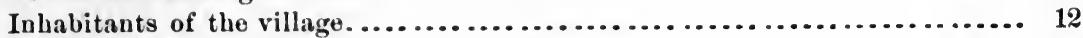

Amahami.................................................. 15

Population $\ldots \ldots \ldots \ldots \ldots \ldots \ldots \ldots \ldots \ldots \ldots \ldots \ldots \ldots \ldots \ldots \ldots \ldots \ldots \ldots \ldots \ldots \ldots \ldots \ldots \ldots \ldots . \ldots \ldots$

Conversation $. . \ldots \ldots \ldots \ldots \ldots \ldots \ldots \ldots \ldots \ldots \ldots \ldots \ldots \ldots \ldots \ldots \ldots \ldots \ldots \ldots \ldots \ldots \ldots \ldots \ldots \ldots . . \ldots 17$

Arts $\ldots \ldots \ldots \ldots \ldots \ldots \ldots \ldots \ldots \ldots \ldots \ldots \ldots \ldots \ldots \ldots \ldots \ldots \ldots \ldots \ldots \ldots \ldots \ldots \ldots \ldots \ldots \ldots \ldots \ldots \ldots \ldots . \ldots 18$

Food, etc $\ldots \ldots \ldots \ldots \ldots \ldots \ldots \ldots \ldots \ldots \ldots \ldots \ldots \ldots \ldots \ldots \ldots \ldots \ldots \ldots \ldots \ldots \ldots \ldots \ldots \ldots \ldots . \ldots 23$

Inter-tribal trade $\ldots \ldots \ldots \ldots \ldots \ldots \ldots \ldots \ldots \ldots \ldots \ldots \ldots \ldots \ldots \ldots \ldots \ldots \ldots \ldots \ldots \ldots \ldots \ldots \ldots \ldots . . . . \ldots 27$

Intercourse with whites $\ldots \ldots \ldots \ldots \ldots \ldots \ldots \ldots \ldots \ldots \ldots \ldots \ldots \ldots \ldots \ldots \ldots \ldots \ldots \ldots \ldots \ldots \ldots . . . . \ldots 8$

\section{Part II,}

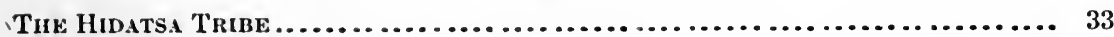

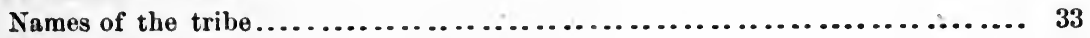

History ................................................ 36

Character................................................. 40

Appearance.... ................. ........................... 42

Ceremonies .............................................. 45

Mythology and superstitions.................................... 47

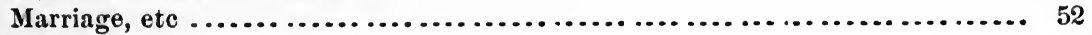

Names .................................................. 54

Relationship ................................................ 55

Hunting ................................................. 57

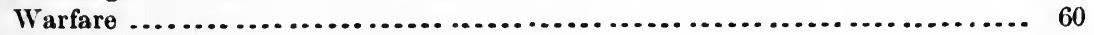

Stories......................................................... 62

Divisions of time $\ldots \ldots \ldots \ldots \ldots \ldots \ldots \ldots \ldots \ldots \ldots \ldots \ldots \ldots \ldots \ldots \ldots \ldots \ldots \ldots \ldots \ldots \ldots \ldots$

\section{PHILOLOGY.}

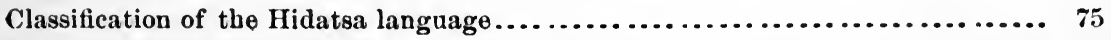

Relations of Dakota to Hidatsa ..................................... 75

Relations of Crow to Hidatsa ..................................... $7 \boldsymbol{7}$

Some difficulties in the study of the Hidatsa $\ldots \ldots \ldots \ldots \ldots \ldots \ldots \ldots \ldots \ldots \ldots \ldots \ldots \ldots \ldots . . . .60$

Sonant character ............................................. 84 
HIDATSA GRAMMAR:

Page.

LETTERS.................................................... 89

Essential letters................................................ 89

Non-essential letters............................................. 90

Remarks ...................................................... 90

SYLLABLES..................................................... 91

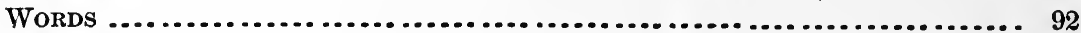

Nouns ..................................................... 92

Primitive nouns............................................... 92

Derivative nouns............................................... 93

Diminutives .................................................. 95

Compound nouns............................................. 95

Properties of nouns............................................ 95

Proper nouns................................................ 97

Syntax of nouns. ............................................. 98

Pronouns........................................................ 98

Personal pronouns ............................................. 98

Relative pronouns............................................ 101

Interrogative pronouns ....................................... 101

Demonstrative pronouns........................................ 101

Syntax of pronouns........................................... 100

Verbs ......................................................... 102

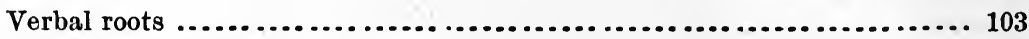

Prefixes and suffixes............................................ 103

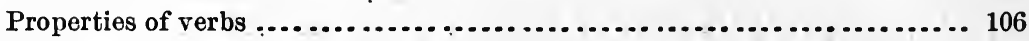

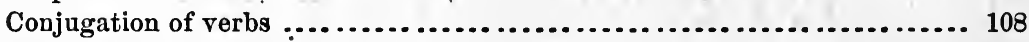

Unconjugated verbs .......................................... 115

Irregular and defective verbs.................................... 115

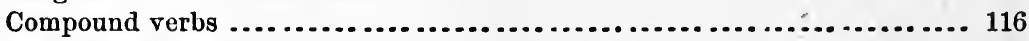

Syntax of verbs............................................. 116

Adjectives.................................................... 116

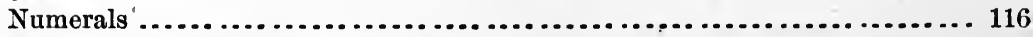

Syntax of adjectives........................................... 118

Adverbs ....................................................... 119

Prepositions ................................................. 120

Conjunctions.................................................... 121

Interjections ................................................. 121

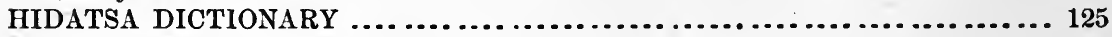

LOCAL NAMES .............................................. 210

ENGLISH-HIDATSA VOCABULARY............................ 215 
E'THNOGRAPHY. 



\section{ETHNOGRAPHY.}

\section{P A R T I.}

THE VILLAGE AT FOR'T BERTHOLD, AND ITS INHABITANTS.

\$1.-The Hillatsa, Minnetaree, or Grosventre Indians, are one of the three tribes which at present inhabit the permanent village at Fort Berthold, Dakota Territory, and hunt on the waters of the Upper Missouri and Yellowstone Rivers, in Northwestern Dakota and Eastem Montana.

The history of this tribe is so intimately connected with that of the politically-allied tribes of the Aricarees and Mandans that we camnot well give an account of one without making some mention of the others. In this first part of the Ethography, all the tribes are included.

\$2. Location.-An arid prairie-terrace, some four miles wide, stretehing southward to the Missouri from the base of bluff's which form the edge of a higher plain, becomes gradually narrower as it approaches the river, and terminates in a steep bluff of soft rock and lignite which overhangs the river. On the southern extremity of this terrace, near the brow of the bluff, stand the Indian village, and what remains, since a recent fire, of the old trading-post of Fort Berthold. This is on the left bank of the Missouri, in latitude $47^{\circ} 34^{\prime}$ north, and longitude $101^{\circ} 48^{\prime}$ west, nearly. About five years ago, a large reservation was declared for them in Dakota and Montana, along the Missouri and Yellowstone Rivers. Fort Berthold is in the northeast corner of this reservation.

$\S 3$. Dwellivgs.-The village consists of a number of 
houses* built very closely together, without any attempt at regularity of position. The doors face in every possible direction; and there is great uniformity in the appearance of the lodges; so it is a very difficult matter to find one's way among. them.

Old-style lodges.-Most of the houses of the village were in 1865 peculiar, large, earth-covered lodges, such as were built by various tribes of Indians of the plains, in the valley of the Missouri, and so often, with varying accuracy, described by travelers.t Each one of these lodges consists of a wooden frame, covered with willows, hay, and earth. A hole in the top, which lets in the light and lets out the smoke, and a doorway on one side, are the only apertures in the building. The door is made of raw-hide stretched on a frame, or of puncheons, and it is protected by a narrow shed or entry from six to ten feet long. Over the smoke-holes of many of the lodges are placed frames of wicker-work, on which skins are spread to the windward in stormy weather to keep the lodges from getting smoky. Sometimes bull-boats are used for this purpose. On the site of a proposed lodge, they often dig down a foot or more, in order to find earth compact enough to form a good floor; so, in some lodges, the floors are lower than the general surface of the ground on which the village stands. The floor is of earth,

"In the fall of 1872 , Dr. C. E. McChesney, then physician at the Berthold agency, connted, with great care, the buildings in the village, aud, in a letter, gave me the following resnlts :--

Old-style (round) lodges of Rees.......................... 43

Log-cabins of Rees .................................... 28

Total number of houses of Rees ..............................

Olil-style lodges of Grosventres and Mandans................... 35

Logr-cabins of Grosventres and Mandans...................... 69

Total number of bonses of Grosventres aud Mandans .............. 104

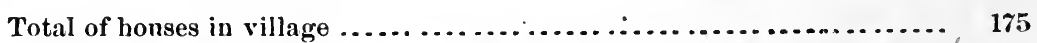

He remarks :- "I could not separate the Grosventres from the Mandans, owing to the stupidity of the interpreter. If anything, this number is uuder, certainly not over: bnt it does not vary more than ten."-Some five or six houses, occupied by white men with Indian families, were probably not included in this enumeration.

$\dagger$ Lewis and Clarke, pp. 73, 78.-Gass, pp. 72, 73.-Maximilian, p. 343.-De Smet, pp. 76-77, and others.-Compare with descriptions of Kanzas, Omaha, and Pawnee lodges in Long's expedition, pp. 120, 200, 436. 
and has in its center a circular depression, for a fire-place, about a foot deep, and three or four feet wide, with an edging of flat rocks. These dwellings, being from thirty to forty feet in diameter, from ten to fifteen feet high in the center, and from five to seven feet high at the eaves, are quite commodious. The labor of constructing them is performed mostly by the women; but, in lifting and setting the heavier beams, the men assist. If, with the aid of steel axes obtained from the whites, the task of building such a house is no easy one at this day, how difficult it must have been a century ago, when the stone ax was their best implement, and when the larger $\log s$ had to be burned through in order that pieces of suitable length might be.obtained!

The frame of a lodge is thus made:-A number of stout posts, from ten to fifteen, according to the size of the lodge, and rising to the height of about five feet above the surface of the earth, are set about ten feet apart in a circle. On the tops of these posts, solid bэams are laid, extending from one to another. 'Then, toward the center of the lodge, four more posts are erected, of much greater diameter than the outer posts, and rising to the height of ten or more feet above the ground. These four posts stand in the corners of a square of about fifteen feet, and their tops are comnected with four heavy logs or beams laid horizontally. From the four central beams to the smaller external beams, long poles, as rafters, are stretched at an angle of about $30^{\circ}$ with the horizon; and from the outer beams to the earth a number of shorter poles are laid at an angle of about $45^{\circ}$. Finally, a number of saplings or rails are laid horizontally to cover the space between the four central beams, leaving only a hole for the combined skylight and chimney. This frame is then covered with willows, hay, and earth, as before mentioned; the covering being of equal depth over all parts of the frame. Earlier writers speak of the supporting-posts of the lodge as being forked. Nowadays, they seldom take the trouble to obtain forked sticks for this purpose.

From the above description, it will be seen that the outline of a vertical section, or of the elevation of such a lodge, is necessarily an irregular hexagon, while that of its ground-plan is 
polygonal, the angles being equal in number to the shorter uprights. Prince Maximilian's artist usually sketches the lodge very correctly; but Mr. Catlin invariably gives an incorrect representation of its exterior. Wherever he depicts a Mandan, Arickaree, or Minnetaree lodge, he makes it appear as an almost exact hemisphere, and always omits the entry. It would seem that, in filling in his sketches, he adopted the hemisphere as a convenient symbol for a lodge. The authors referred to by name in the foot-note on page - speak of the entry or passage. $^{*}$

A partition of puncheons, poles, or hurdles is often raised between the fire-place and the door, particularly in cold weather, to shelter the group around the fire-place when the door is opened. Mats, hurdles, hair-pillows, and buffalo-robes laid on the ground constitute the seats. Curtained bedsteads are arranged around the circumference of the lodge, between the shorter uprights. Arms, implements, household-utensils, medicinebags, etc., are hung from pegs on the various supporting-posts of the lodge. A wooden mortar, wherein corn and meat are pounded, is set in the earthen floor. The space between the outer row of supporting-posts and the outer wall is called 'atuti', or bottom of the lodge, and in it stored bull-boats, skinlodges, and various other articles; here, too, we usually find the sudatory. Valuable horses are often housed at night in these lodges, in a pen near the door; but the residents of the loghouses, to be described hereafter, keep horses in separate sheds outside.

Log-houses.-Every winter, until 1866, the Indians left their permanent village, and, moving: some distance up the Missouri Valley, built temporary quarters, usually in the center of heary forests and in the neighborhood of buffalo. The chief objects of this movement were that they might have fuel convenient, and not exhaust the supply of wood in the neighborhood of the permanent village. It was also advisable that, during a portion of the year at least, they should not harass the game near home. The houses of the winter-villages resem-

* Perhaps it wonld be well to illustrate this with a copy of plate 47, vol. 1, of Catlin, and a copy of the figure on p. 343 of Maximilian. 
bled much the log-cabins of our own western pioneers. They were neatly built, very warm, had regular fire-places and chimneys built of sticks and mud, and square holes in the roofs for the admission of light. 'T'en years ago, there were some cabins of this description in the permanent village at Fort Berthold; every year since, they are becoming gradually more numerous and threaten to eventually supplant the original earthcovered lodges. By reference to the note on page 4, it will be seen that, in 187 ', the former outnumbered the latter by about nimeteen.

Skin-lodges.-The practice of building winter-quarters is now abandoned. As game has recently become very scarce in their country, they are obliged to travel immense distances, and almost constantly, when they go out on their winter-hunts. Requiring, therefore, movable habitations, they take with them, on their journeys, the ordinary skin-lodges, or "tepees", such as are used by the Dakotas, Assiniboines, and other nomadic tribes in this region. Such lodges, too, they have always used on their summer-hunts, and on all long journeys except with warparties. 'The skin-lodges of the prairie Indians have been so often described and depicted that any further reference to them in this paper would be umnecessary. It is enough to say that the tribes here considered, construct them in the same manner as do their neighbors, often ornamenting them with paintings, quill-embroideries, and other decorations.

Hunting-lodges.-In one of his "Solitary Rambles", Palliser" found, on the Turtle Mountain, four days journey from Fort Berthold, in the spring of 1858, a Minnetaree hunting-lodge of which he says:- "They had built a triangular lodge of long wooden poles, like hop-poles, piling them in the shape of a cone, and so closely as to render the hut bullet-proof, a necessary precaution, as they could never venture there save in fear of their lives, the position lying in the regular pass of the Sioux, when they go to war with either them or the Crows. We took possession of the hut, not sorry to feel ourselves in a bulletproof shelter, in a place where, I must admit, we ran some risk of being surprised by an Indian war-party."* 
In the winter of 1871 , while hunting with a party of Indians from the Berthold village, in the bad-lands of the Little Missouri, I spent three nights in a lodge of exactly the same kind, which was quite old, and had often served as the temporary shelter of Hidatsa hunting-parties. It stood in an excellent but dangerous game-region, some four or five days journey from Fort Berthold, and was built for the convenience of parties composed only of men who found it advisable to visit that neighborhood without tents or other incumbrances. There are probably other lodges of this kind in the country around Berthold, but I have seen only this orie.

\$ 4. Drying-Frames, corn-scaffolds, or, as some call them, "gridirons", stand in various parts of the village, and are quite numerous. They must resemble much the drying-frames of the agricultural tribes of the far east and south, if we are to judge by the descriptions given. They seem to differ in shape from those of the Omahas- of which the writer has seen photographs, but not the originals-by having the supporting-posts longer, and rising above the floor. They are made by setting in the ground some six or eight saplings, which rise to the height of twelve or fifteen feet. To these, at the height of seven or eight feet, cross-pieces are lashed; and on the latter a floor of poles or willow hurdles is laid; smaller poles are lashed to the tops of the upright supports. Corn and other vegetables, meat, robes, etc., are dried on these frames; and the labor of preparing and cleaning corn is done on the hurdlefloor, or on the ground underneath.

\$5. Caches.-The numerous caches, or pits, for storing grain, are noteworthy objects in the village. In summer, when they are not in use, they are often left open, or are carelessly covered, and may entrap the un wary stroller. When these Indians have harvested their crops, and before they start on their winterhunt, they dig their caches, or clear out those dug in previous years. A cache is a cellar, usually round, with a small opening above, barely large enough to allow a person to descend; when finished, it looks much like an ordinary round cistern. Reserving a small portion of corn, dried squash, etc., for winter use, they deposit the remainder in these subterranean store- 
houses, along with household-utensils and other articles of value which they wish to leave behind. They then fill up the orifices with earth, which they trample down and rake over; thus obliterating every trace of the excavation. Some caches are made under the floors of the houses, others outside; in various parts of the village-grounds; in each case, the distance and direction from some door, post, bedstead, fire-place, or other object is noted, so that the stores may be found on the return of the owners in the spring. Should an enemy enter the village while it is temporarily deserted, the goods are safe from fire and theft. This method of secreting property has long been in use among many tribes, has been adopted by whites living on the plains, and is referred to in the works of many travelers.

$\$ 6$. Cemetery.-Burials.-On the prairie, a short distance behind the village, are scattered around the scaffolds and the graves whereon and wherein are deposited the dead. Formerly, all who died in the village were placed on scaffolds, as is the custom with most of the Missouri Valley tribes; but the practice of burying in the ground, after the mamner of the Europeans and Arickarees, is gradually becoming more common; and every year the scaffolds decrease, and the graves increase in number. When at a distance from their village on their hunts, if encamped in the neighborhood of timber, they lay the corpses in the branches of the trees instead of building scaffolds.

\$7. Places of worship.-There are, in the village, two open spaces, which, although of irregular shape, may be called squares; one of these is in the Mandan, the other in the Arickaree quarter. Beside each square stands a large round "medicine-lodge", or temple, built as described in the second paragraph of $\$ 3$, which is used for purposes that, in a general way, are called religious.

In the center of the Mandan square is a small circular palisade, about six feet high and four feet in diameter, made of neatly-hewn puncheons set closely together. It has somewhat the appearance of a large barrel, and is emblematic of the ark in which, according to Mandan mythology, the sole survivor 
of the Deluge was saved. The square, the medicine-lodge, with its four poles in front, surmounted by sacrificial effigies, and the ark, as they may be seen at Fort Berthold to-day, seem to be the almost exact counterparts of those which were seen in the old Mandan village at Fort Clarke, in 1832 and 1833, by George Catlin and the Prince of New-Wied, if we are to judge by the drawings they have given us. Within the temple and around the ark, the Mandans still perform the ceremony of the Okeepa, which Catlin so accurately describes. The awful severities of the rite have, however, been somewhat mitigated since his day.

The medicine-lodge of the Arickarees is larger than that of the Mandans, and is used for a greater variety of ceremonies. Some of these performances, consisting of ingenious tricks of jugglery and dances, representative of various hunts, we might be inclined to call theatrical rather than religious. Probably these Indians consider them both worshipful and entertaining. It is often hard to tell how much of a religious ceremony is intended to propitiate the unknown powers, and how much to please the spectators.

The Grosventres, or Hidatsas, have no house especially devoted to their "medicine". Some of their minor rites are performed in ordinary dwellings, in temporary houses, or in the open air. Their most important ceremony is conducted in a structure of willows erected for the occasion around a tall forked log. After the ceremony (described in $\$ 22$ ), the log, or pole, is left standing until the forces of nature throw it down. Several of these logs, in various stages of decay, may be seen on the prairie between the village and the cemetery.

$\S 8$. Fortifications.-Many travelers have described their towns as being fortified,* sometimes with walls, but usually with ditches and stockades, or with stockades alone. The latter system of defense was in use at the village of Fort Berthold until the winter of 1865 , when. they cut down the palisades for fire-wood; and they have never since restored them. 'The presence of United States troops in their neigh-

* Lew is and Clarke, pp. 69, 70, 72, 73, 74, 8*, 84, etc.-Maximiliat1, p. 342._Catlin, N. A. Indians, pp. 73, 204. 
borhood, and the growing weakness of the Dakotas, were probably the causes which led them to discontinue their fortifications.

\$9. Farms and farming.-From the base of the prairieterrace described in $\{2$, the bottom lands of the Missouri extend to the east and to the west, up and down the river. In the neighborhood of the village, they are covered partly with forest-trees, willows, and low brush, but chiefly with the little fields or gardens of these tribes.

Five years ago, all the land cultivated around the village consisted of little patches, irregular in form and of various sizes, which were cleared out among the willows. The patches were sometimes separated from one another by trifling willowfences; but the boundaries were more commonly made by leaving the weeds and willows uncut, or small strips of ground uncultivated, between the fields. Every woman in the village capable of working had her own piece of ground, which she cultivated with a hoe; but some of the more enterprising paid the traders in buffalo-robes to plow their land. They raised the plants which nearly all the agricultural tribes of the temperate regions cultivated at the time of the discovery of America-com, squashes, beans, and tobacco. They also improved the growth of the wild sunflower, the seeds of which they eat. Their system of tillage was rude. They knew nothing of the value of manuring the soil, changing the seed, or alternating the crops. Perhaps they had little need of such knowledge; for when the soil was worn out, they abandoned it; and there was no stint of land in the wilderness. Sometimes, after a few year's of rest, they would resume the cultivation of a worn field that was quite near the village, for proximity lent some value to the land; but they had no regular system of fallowing. They often planted a dozen grains of corn or more to the hill, and did not hoe very thoroughly.

Within the last few years, there has been an improvement in their farming. The bottom to the west of the village is still divided up and cultivated in the old way; but the bottom to the east and a part of the upland have been broken up by the Indian agency, fenced, and converted into a large field. A 
portion of this field is cultivated (chiefly by hired Indians) for the benefit of the agency, and the rest has been divided into small tracts, each to be cultivated by a separate family for its own benefit. Potatoes, turnips, and other vegetables have been introduced. The men apply themselves willingly to the labors of the field; and the number of working men is constantly increasing.

The Arickarees and Mandans have doubtlessly tilled the soil for many centuries. Their accounts of the origin of corn are mingled with their earliest myths and traditions. There are some reasons for believing that the Arickarees represent an older race of farmers than the Mandans; for their religious ceremonies connected with planting are: the more numerous, and they honor the corn with a species of worship. In every Arickaree lodge, there is a large ear of corn, which has lasted for generations, sticking out of the mouth of a medicine-bag. At their feasts, they make offerings to the corn by rubbing a. piece of meat on it, while they pray to it for plentiful harvests, and address it by the name of "mother". The Hidatsas claim to have had no knowledge of corn until they first ate it from the trenchers of the Mandans; and they have no important ceremonies connected with the harvesting, yet they cultivated it long before the advent of the white man.

In favorable years, they had good harvests, and were able to sell corn to other Indians and to their traders, besides keeping all they wanted for their own use. But they are not always thus fortunate, for the soil of their country, even that on the Missouri bottoms, is not very rich; the summer season is short, with early and late frosts; the climate is dry; long droughts often prevail, to guard against which they have no system of irrigation; and, lastly, the grasshoppers - the plague of the Missouri Valley farmer-have often devoured the crops that had escaped all other enemies, and left the Indian with little more than seed enough for the coming spring.

$\S 10$. Inhabitants of the village.-When Lewis and Clarke ascended the Missouri, in 1804, they found four tribes of. agricultural Indians, numerous and prosperous, inhabiting the Upper Missouri Valley, west of the Dakota nation. They had 
eight permanently inhabited towns, others which they lived in only temporarily, and a number more which they had abandoned and allowed to go to ruin. They are spoken of in Lewis and Clarke's journal as the "Ricaras," "Mandans," "Minnetarees," and "Ahnahaways." All that are left of the four tribes are now gathered together in this one village, at Fort Berthold, which does not probably number 2,500 souls. The remains, now nearly obliterated, of their old towns, may be traced on nearly every prairie-terrace adjacent to the Missouri, along six hundred miles of its course, from the mouth of the Lower White-Earth to the mouth of the Little Missouri. The Indians at Fort Berthold are, however, now generally referred to as "the three tribes"; for one of the nations spoken of by Captain Lewis-that which he calls Ahnahaways-is no longer an organized tribe, but has been merged into the Minnetarees. (See $\$ 11$.

Arickarees.-The first-mentioned tribe is known by the various names of Arikaras, Ricaras, Arickarees, and Rees, all of which are from their Mandan name, Aríkara. They are related to the Pawnees of the Platte Valley, from whom they separated more than a century ago. In 1804 , they were found living farther down the Missouri than the Hidatsa and Mandan tribes, and were at war with the latter. 'They made peace in the course of time, and gradually followed the other tribes up the Missouri, building new villages and abandoning old ones as they went. In August, 1862, they moved to Fort Berthold, and began to erect houses there beside those of the Mandans and Minnetarees. These three tribes have ever since occupied the same permanent village. Descriptions of the Arickarees, as they were seen at different periods, may be found in the works of Lewis and Clarke, Catlin, Maximilian, and Hayden. Lewis and Clarke give accounts of many of their early migrations, and the lastnamed three authors furnish vocabularies of their language.

The Mandans, about a hundred years ago, lived in several villages near the mouth of Heart River. From this neighborhood, they moved up the Missouri, stopping and building villages at different localities.* In 1804 , they were found

* For an account of these movements, see Lewis aud Clarke, pp. 83-85. 
dwelling in two towns about four miles below the mouth of Knife River. One of these towns was named Métutahanke, Mitutahankish, or, as Maximilian writes it, "Mih-tutta-hangkusch," meaning Lower Village. The other was called Rùptari or Nuptadi. They were almost exterminated by the smallpox in 18:37, after which, for a time, they occupied only one village. In 1845 , when the Hidatsas moved away from Knife River, some of the Mandans went with them, and others followed at different times afterward. For a short time, it appears that a few Mandan families occupied the old Amahami village. We have an account of some moving up to the village at Fort Berthold as late as 1858 , and of others still remaining at the mouth of Knife River at the same time.*

The word Mandan seems to be a corruption of the Dakota name Matani or Mawatani. Previous to 1837 , they called themselves simply Numakaki, i. e., People, Men. They sometimes spoke of themselves and the Minnetarees together as Núweta, Ourselves. A large band of their tribe was called Siposka-numakaki, Prairie-hen People, or Grouse Men.† This name, Mr. Catlin, in his first work, renders "People of the pheasants", $\ddagger$ and, in his last work, presents in the shape of "Nu-mah-ká-kee (pheasants)", $§$ and then, from this translation, leaves us to draw the "important inference" that the Mandans once lived in the Ohio Valley. They now often call themselves Metutahanke, after their old village below Knife River.

Captains Lewis and Clarke, Mr. Catlin, the Prince of Neuwied, and Dr. Hayden have written very full accounts of this tribe, and all but the first-named explorers present vocabularies of their language. The work of Prince Maximilian contains the most accurate and extensive information regarding their customs and manners. Notwithstanding the great changes in the tribe since 1834, the majority of his notes might be used without alteration in describing the Mandans of

${ }^{*}$ Boller, pp. 35, 36.

† The Mandan name Siposka (Hidatsa, sitska or tsitska) is applied to the Tetrao phasianellus (Linn.) or Sharp-tailed Grouse, the prairie-hen of the Upper Missouri.

$\ddagger$ N. A. Indians, vol. i, pp. 80, 178; vol. ii, p. 260 .

§ O-kec-pa, pp. 5, 44. 
to-day. In a few cases, however, I believe that the deductions which he drew from his observations were incoirect.*

Minnetarees.-Since the other one of the three tribes, the Hidatsas or Minnetarees, forms the principal subject of this essay, it is spoken of at length; the description forming the second part of this sketch.

\$11. Amainami.-The people who, by Lewis and Clarke, are generally called Ahnahaways, and, in this dictionary, Amaami, were closely allied to the Hidatsa, and spoke a language differing but slightly from that of the latter; yet they occupied a separate village and long maintained a distinct tribal organization. Their village, in 1804 , was at the mouth of Knife River, and was one of three villages which for many years stood on the banks of that stream.' (See $\$ 19$.) In 1804, they were estimated as numbering about fifty warriors. In 18:33-34, their village was said to contain eighteen houses.f These estimates indicate that there was no material change in their numbers during the intervening thirty years. After the epidemic of 1837 , the whole or the greater part of the survivors joined the Hidatsa, and, as before stated, merged into the latter. In what year this fusion took place, I was unable to determine; it inay have been gradual. A few of the Amahamis perhaps identified themselves with the Mandans. In 1858, after the Hidatsa had left Knife River, Boller saw some persons occupying a few huts at the mouth of Knife River, probably the old Amahami village. He says, however, that the occupants were Mandans. $\$$

Lewis and Clarke evidently regarded these people as distinct from the dwellers in the other two villages on Knife River; \# but Catlin seemed to think that the Amahami village was merely one of the Minnetaree villages, for he says that the Minnetarees occupied the three villages on Knife River; I and the Prince of Neuwied seems to agree with Mr. Catlin.** Perhaps in the

" Thus, in speaking of the custom of carrying small bundles of sticks (p. 356), which then existed, and still to some extent exists, anong the young men of the Mandans and Minnetarees, he says, "They do not meet with many coy beauties." If such were the case, why should they display tokens of their success? Why boast of a deed which was no great achievement?

† Lewis and Clarke, p. 96.

@p.36.

|| p.p. $89,95,97$.

$\ddagger$ Maximilian, p. 178.

ๆ p. 185.

** p. 178. 
days of these latter travelers, the Amahamis may have submitted to the authority of the Minnetaree chief.

In one instance, Lewis and Clarke spell the name of this tribe "Arwacahwas".* In 1834, their village stood on the same ground that it occupied in 1804; at both of these dates it bore the same Indian names, $\uparrow$ and the people bore the same French name; $\ddagger$ yet Maximilian, aided by his interpreter, failed to recognize the resemblance between the name of the tribe as written by Lewis and Clarke and "Awachawi", as he, according to German orthography, so correctly spells it. Such, at least, is the impression produced by the perusal of the foot-note on page 335 of his work. In this note, too, Maximilian, in criticising Lewis and Clarke's spelling, does not make due allowance for the fact that the American travelers wrote in a language whose alphabet is less suited to express the Indian words than that of the language in which he wrote.

The descendants of the Amahamis, among the Hidatsa, are now known from the rest of this tribe by their preference for certain words and dialectic forms, which are not in common use among those of unmixed Hidatsa blood, and did not originally belong to the language of the latter.

$\$ 12$. Population.-The population of the village is not known. It is said that the inhabitants of some of the old villages allowed a census to be taken immediately before the epidemic which proved so fatal to them. They believed that their calamity resulted from the census, and have since resisted all efforts to ascertain their numbers. Many ingenious plans have been devised for counting them without their knowledge, but they have suspected and thwarted them all. In the Reports of the Commissioners of Indian Affairs, various estimates of their strength may be found, but they are all conjectural. In the Report of 1862 , it is stated $\S$ that the Grosventres and Mandans, in that year, numbered 1,120, and the Arickarees (then in a separate but neighboring village) 1,000 ,-total 2,120 . In

*p. 89.

†Lewis and Clarke, p. 89, "Mahawba".-Maximilian, p. 335, "Machacha".

$\ddagger$ Lewis and Clarke, p. 96, " called by the French Soulier Noir, or Shoe Indians.' -Maximilian, p. 178, "Le village des Souliers."

$\oint$ Pages 193 and 195, in Report of Agent S. N. Latta to the Commissioner. 
the Report of 1866 are the following "approximate numbers":* Arickarees, 1,500; Mandans, 400; Grosventres, 400 ;-total 2,300 . In the Report of 1871 , the population is thus given: $\dagger$ Arickarees, 1,650; Grosventres, 600; Mandans, 450;-total "about" 2,700. In these estimates, which vary greatly, the first gives the population of the Grosventres and Mandans together as more than the Rees; while, in the second and third estimates, the Rees are represented as about twice as numerous as the other two tribes together. In this respect, I believe the first quoted estimate to be nearest the truth; for the houses occupied by the Grosventres and Mandans number more than those occupied by the Rees. $\ddagger$ In the estimate of 1866 , it will be seen that the Grosventres and Mandans are represented as equal to one another. I have many reasons for believing this representation to be incorrect. The conjecture of the writer, based upon all ascertainable data, is that, within the past ten years, the proper population of the village has never been more than 2,500, and that, at present, it is much less. It is pretty certain, too, that of the three tribes the Arickarees stand first in numerical strength, the Hidatsa second, and the Mandans third.

However, if a perfect census of the village was taken any day, when no hunting-parties were out, it would not show the strength of these tribes; for the scouts who are enlisted at distant posts, their families, and the Minnetarees, who, of late years, have gone to live with the Crows, constituting in all a large proportion of this people, could not be included.

\$13. Conversation.-To the philologist, it is an interesting fact that this trio of savage clans, although now living in the same village, and having been next-door neighbors to each other for more than a hundred years, on terms of peace and intimacy, and to a great extent intermarried, speak, nevertheless, totally distinct languages, which show no perceptible inclination to coalesce. The Mandan and Grosventre (or Minnetaree) languages are somewhat alike, and probably of a very distant common origin; but no resemblance has yet been discovered between either of these and the Arickaree ("Ricara").

" Page 175, in Report of the Northwestern Treaty Commissioners.

+ Page 520, in Report of Agent J. E. Tappan.

$\ddagger$ See note on p. 4. 
Almost every member of each tribe understands the languages of the other tribes, yet he speaks his own most fluently; so it is not an uncommon thing to hear a dialogue carried on in two languages, one person, for instance, questioning in Mandan, and the other answering back in Grosventre, and vice versa. Many of them understand the Dakota tongue, and use it as a means of intercommunication, and all understand the sign-language. So, after all, they have no trouble in making themselves understood by one another. These Indians must have excellent memories and "good capacity for study"; for it is not uncommon to find persons among them, some even under twenty years of age, who can speak fluently four or five different languages.

\$14. Arts.-Besides their agriculture and architecture, which have been already alluded to, they had the knowledge of many other useful arts, still practiced by them, which were entirely of native origin. They manufactured pottery; built boats of buffalo-hide; made mats and baskets of various descriptions, and wooden bowls so durable that they last for many generations; and formed spoons and ladles out of the horns of the buffalo and Rocky Mountain sheep. Their hair-brushes they made sometimes out of porcupine-quills, but more commonly of grass - the long, tough awns of the Stipa juncea. They fashioned whistles of the bones of large birds, and fifes and other wind-instruments out of wood; some of these were for musical purposes; others were to imitate, for the hunter's benefit, the bleat of the antelope or the whistle of the elk. They garnished their clothing with porcupine-quills, which they colored brilliantly with dye-stuffs of Indian discovery. They had flint and horn arrow-heads, and horn wedges with which they split wood. They knew something of the manufacture of glass, and made rude beads and pendants out of it; they possessed various pigments, and with them recorded the events of their day in symbolic pictures; and, in the manufacture and use of the various appliances of war and the chase, they had no superiors on the plains. Their arms were the same as those of the Dakotas and other western tribes; and they have been so often described that I feel there is little left for me to say concerning them. 
For cleaning the village-grounds, they had rakes made of a few osiers tied together-the ends curved and spreading. Their most important agricultural implement was the hoe. Before they obtained iron utensils of the white traders, their only hoes were made of the shoulder-blades of elk or buffalo, attached to wooden handles of suitable length. Maximilian, in 1833,* considered the bone hoe as a thing of the past only; yet, as

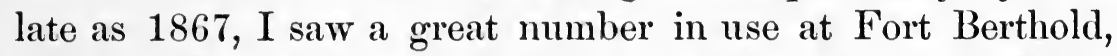
and purchased two or three, one of which was sent to Washington, and, I presume, is now on exhibition in the museum of the Smithsonian Institution. $\dagger$

They now make saddle-trees in somewhat the same way as we do, of wood or of part wood and part horn, covered with raw-hide. They also make neat pad-saddles of tanned elk-skin, stuffed with antelope-hair, and often handsomely embroidered, as well as other horse-equipments. They probably learned the art of making these articles some time during the last century, from the Indians of the south, of whom they first obtained horses.

For their children, they make toys, which, as with us, indicate for each sex the occupations of adult years. When the children are old enough, they make some of their own toys. They have pop-guns, the art of making which, as far as I could discover, was not learned from the whites. The boys make representations of hunts by fashioning out of mud, with much skill, little figures of the horse, the mounted hunter, and the flying buffalo.

Glass.-The articles of glass spoken of abeve are chiefly of two kinds : first, large, globular, or ellipsoidal beads; and, second, flat, irregularly triangular plates or pendants, which are glazed only on one side, and have a hole at the apex. The art of making these deserves more than a mere mention, since it is commonly believed that the aboriginal Americans, even the most civilized races, knew nothing of the manufacture of glass at the time of the Columbian discovery. The very earliest ethnographical account we have of the Arickarees and Man-

p. 347.

t See Smithsonian Report for 1869 , p. 36 , where the specimen is erroneously attributed to the Yanktonnais. 
dans shows that they knew how to make glass beads; and there is no doubt that the process employed in 1804 was essentially the same as that employed to-day. The following is the account of this given by Lewis and Clarke:- "A Mr. Garrow, a Frenchman, who has resided a long time among the Ricaras and Mandans, explained to us the mode in which they make their large beads, -an art which they are said to have derived from some prisoners of the Snake Indian nation, and the knowledge of which is a secret, even now confined to a few among the Mandans and Ricaras. The process is as follows: glass of different colors is first pounded fine, and washed, till each kind, which is kept separate, ceases to stain the water thrown over it; some well-seasoned clay, mixed with a sufficient quantity of sand to prevent it becoming very hard when exposed to the heat, and reduced by water to the consistency of dough, is then rolled on the palm of the hand till it becomes of the thickness wanted for the hole in the bead; these sticks of clay are placed upright, each on a little pedestal or ball of the same material, about an ounce in weight, and distributed over a small earthen platter, which is laid on the fire for a few minutes, when they are taken off to cool; with a little paddle or shovel, three or four inches long and sharpened at the end of the handle, the wet pounded glass is placed in the palm of the hand; the beads are made of an oblong form, wrapped in a cylindrical form round the stick of clay, which is laid crosswise over it, and gently rolled backward and forward until it becomes perfectly smooth. If it be desired to introduce any other color, the surface of the bead is perforated with the pointed end of the paddle, and the cavity filled with pounded glass of that color; the sticks, with the string of beads, are then placed on their pedestals, and the platter deposited on burning coals or hot embers; over the platter an earthen pot, containing about three gallons, with a mouth large enough to cover the platter, is reversed, being completely closed, except a small aperture in the top, through which are watched the beads; a quantity of old dried wood, formed into a sort of dough or paste, is placed round the pot so as almost to cover it, and afterward set on fire; the manufacturer then looks 
through the small hole in the pot till he sees the beads assume a deep-red color, to which succeeds a paler or whitish red, or they become pointed at the upper extremity, on which the fire is removed and the pot is suffered to cool gradually; at length it is removed, the beads taken out, the clay in the hollow of them picked out with an awl or needle, and it is then fit for use. The beads thus formed are in great demand among the Indians, and used as pendants to their ears and hair, and sometimes worn round the neck." * This art is now only occasionally practiced in the village, and is mostly confined to the making of the flat, triangular pendants. I have heard the process described in much the same way as in the above quotation. From this quotation, however, which is in part ambiguous, the inference might be drawn that the ornaments, when completed, consist entirely of glass. Such is not the case in those I have seen; on the contrary, they consist of a core of baked earth covered with a thin shell of glass; and they have the appearance of having been perforated before heat was applied. But, in the matter of making the holes, the process may have been changed, or there may have been two ways of doing it.

The existence of this art among the Indians evidently greatly astonished Catlin, who gives it as one of the reasons on which he founds his theory of the Cymric origin of the Mandans. He says, speaking of the Mandans:-"In addition to this art," [pottery,] "which I am sure belongs to no other tribe on the continent, these people have also, as a secret with themselves, the extraordinary art of manufacturing a very beautiful and lasting kind of blue glass beads, which they wear on their necks in great quantities, and decidedly value above all others that are brought among them by the fur-traders.' "This secret is not only one that the traders did not introduce among them, but one which they cannot learn from them; and at the same time, beyond a doubt, an art that has been introduced among them by some civilized people, as it is as yet unknown to other Indian tribes in that vicinity or elsewhere. Of this interesting fact, Lewis and Clarke gave

\footnotetext{
* pp. 125-126.
} 
an account thirty-three years ago, at a time when no traders or other white people had been among the Mandans to have taught them so curious an art." * It is surprising that Mr. Catlin, after reading the above-cited passages from Lewis and Clarke (and he leaves us to infer that he has read them), could state that the art of making these beads was confined to the Mandans; that it was unknown to the traders; that it was beyond doubt introduced by civilized people; and that no traders or other whites had been among these Indians before the time of Lewis and Clarke's visit.

The art of making these ornaments would appear to be old; yet the process as it existed in 1804 was evidently in part recent, since the Indians obtained the giass which they used from the whites. I have been informed by the Indians that in old days the art flourished among the Arickarees as well as among the Mandans; and certainly at the present day the Arickaree women understand it. I had two of the triangular pendants made to order in 1870 , by an Arickaree woman, to whom I furnished the blue glass necessary. When I gave instructions to have the articles made, I was invited to witness the process, but circumstances prevented me from doing so. One of these pendants was sent to the Smithsonian Institution. It is strange, if true, that these Indians should have obtained their knowledge of this art from the Snake Indians, a ruder and equally remote tribe. It is also strange, and undoubtedly true, that in 1804, as well as now, they did not make their glass, but obtained it ready-made, and merely fused it for their purposes, obtaining it, doubtlessly, from the whites. It is strange that within a few years after glass beads of European manufacture were first introduced among them, and when such beads must have commanded a high price, they should pulverize them and use the powder in making ruder and more unsightly articles after their own design. But it is not probable that they should have learned such an art from civilized people prior to 1804 , when they had as yet seen but few whites, and when the whites they had seen were mostly rude Canadian frontiersmen, among whom it is not reasonable to suppose

* North American Iudians, vol. ii, p. 201. 
there were any persons versed in glass-making. I have heard Indians say, with uncertainty, that in former times they found. glass in the hills, and pounded it for their beads; meaning perhaps that they used natural glass, which may be found where lignite beds have taken fire, and elsewhere on the Upper Missouri. In view of all these facts, I have conjectured that they had the art of making glazed earthen ornaments before the whites came among them; and that when they saw the brilliantly-colored beads of the traders, they conceived the idea of improving their art by using these beads. If they ever possessed the art of making glass de novo, there is no record, tradition, or other evidence of it that $I$ have been able to find.

One of many reasons, though perhaps an insufficient reason, for believing the art to be of no recent origin among them, is that they used the triangular pendants, not as ornaments only, but as evidences of betrothal, as long ago as the oldest men can remember. When a girl was promised in marriage in her infancy by her parents, as was not infrequently done, one of these pendants was tied to her forelock so as to hang down over her forehead. When the promise was fulfilled, the husband removed the pendant and threw it away.

$\$ 15$. Food, Erc.- Since the introduction of various articles of European food, their diet has been somewhat changed, yet they still largely adhere to their original dietary.

Their chief food, until within the last eight or ten years, was the meat of the buffalo, or bison, which, when fresh, was cooked by roasting before an open fire, by broiling on the coals or on an extemporized wooden broiler, or by boiling. Their meat was boiled in earthen pots before brass and iron pots were introduced by the whites. They knew the different effects produced by putting the meat down in hot and in cold water, and employed the former method when they did not want soup. On hunts, they sometimes boiled the meat in skins, heating the water with hot stones, after the method employed by the Assinniboines, which has given the latter tribe its name of Stone-cookers. Sometimes they chopped the fresh meat fine, put it in a piece of bowel, and thus made a sort of 
sausage, which was usually boiled. For preservation, meat is cut.into thin sheets or into long strips and dried in the sun. I have seen dried meat three years old perfectly sweet. Sometimes it becomes worm-eaten without becoming rancid. In rainy weather, they often hang meat up in the smoke of the lodge to preserve it. The dried meat is sometimes eaten raw, but more frequently it is boiled or broiled; or it is broiled, pounded fine, and mixed with fat to make pemmican. They sometimes add sugar and berries to small quantities of pemmican. The meat of the elk and the deer is cooked and prepared in the same way as buffalo-meat, and of late, since the buffalo have so greatly decreased in number, is more used than the latter.

When game is abundant, they only use choice parts of an animal; but, when it is scarce, they discard nothing. They then pound the bones into small fragments, and subject them to prolonged boiling to make soup. During one winter of great scarcity, I knew of some Arickarees, who, not having horses, could not go out on the winter-hunt, to cut up and boil their bull-boats and the raw-hide doors of their houses for food. When hungry hunters kill an animal, they often eat the liver, the kidneys, and the hoofs of the foetus, should there be one, raw. Raw liver is said to have a saccharine taste which is not unpleasant. Occasionally they eat other parts raw, but this is only when the quarry is little, the mouths many, and the prospect of a fire distant or doubtful.

Fat porcupine, bear, and beaver meat are esteemed, particularly the tail of the latter. They are fond of marrow and fat. Birds of prey, foxes, and wolves are eaten, but only when food is scarce. Turtles and fish are used as food; but I have never heard of any such use being made of srakes. The Grosventres have but recently learned to eat dog-flesh, and they still eat horse-flesh only under pressing necessity; but the Arickarees seem to have less prejudice to such food. Among many belonging to these tribes, a young, fat pup is considered a great delicacy. Insects, with one exception, and worms are never eaten, and few can now be persuaded to eat oysters. When a gravid buffalo, elk, or deer is killed, the liquor amnii 
is generally preserved and boiled for soup, the fotus being cooked in it.

Formerly, they lived largely upon meat. When out on their hunts and war-parties, they often lived exclusively on it. There were many nomadic tribes around them who seldom tasted vegetable matter, often living for seven or eight months in the year exclusively on meat, and preserving perfect health. I have seen white men who had lived for years among the Indians, and during such residence, for six months of every year, lived on nothing but meat (and water of course), "Buffalo straight," as they expressed it, and who, in the summers only, occasionally varied their diet with a mess of roots or berries-not seeking such vegetable food with any particular: longing or avidity. In various books of western travel, these statements are corroborated; yet there are modern physiologists who would try to persuade us that an animal diet is inadequate to the sustaining of human life in a healthy condition. When subsisting for the most part on fresh meat, these Indians had the soundest gums and teeth; and no flesh when wounded healed more rapidly than theirs. Lately, however, since the increase in the consumption of bacon and flour among them, and the destruction of their game, there have been many cases of scurvy, a disease which was particularly fatal to them in the winter of $1868-69$; and a tendency to abscesses, to suppurative terminations of diseases, and to a sluggish condition of wounds, manifests itself. The quantities of fresh meat they are able to consume are enormous. Sometimes, after a day's hunt, the hunters will sit up all night cooking and eating.

Their principal vegetable diet was the corn they raised themselves. Flour, issued by the agency, is now, to a great extent, taking its place. They eat some of the corn when it is green, but the greater part they allow to ripen. When ripe, they prepare it in various ways. They pound it in a wooden mortar with water, and boil the moist meal thus made into a hasty pudding, or cook it in cakes. They frequently parch the corn, and then reduce it to powder, which is often eaten without preparation. A portion of their corn they boil when nearly ripe; they then dry and shell it, and lay it by for win- 
ter use; when boiled again, it tastes like green corn. (See Madaśkihe in Dictionary.) This is often boiled with dried beans to make a succotash. Their beans are not usually eaten until ripe. Squashes are cut in thin slicês and dried; the dried squash is usually cooked by boiling. Sunflower-seeds are dried, slightly scorched in pots or pans over the fire, and then powdered. The meal is boiled or made into cakes with grease. The sunflower-cakes are often taken on war-parties, and are said, when eaten even sparingly, to sustain the consumer against fatigue more than any other food. They gather all manner of wild roots and berries that are eaten by the nomadic tribes of the same region; but they do not consume them to the extent that the wilder tribes do. The only nuts that grow in their hunting-grounds are the acorns. I have never known them to collect or eat these.

I believe that they have always understood the value of salt and knew where to procure it. (See Matamahota in Dictionary.) They used it sparingly, however, and to season their vegetable messes only. Lately, since they can obtain salt so cheaply and plentifully from the traders and agency, they rarely hunt for it, and use it to a greater extent than they formerly did. In 1820, Major Long's Expedition met an Arickaree returning from the distant valley of the Arkansas, with about thirty pounds of pure salt, which " had evidently been formed by the evaporation of water in some pond or, basin."*

In the earliest accounts that we have of these Indians, we find they cultivated a species of tobaccot (Nicotiana quadrivalvis). Sergeant Gass, who tried it in 1804, and who, we may presume, was a good judge of the weed, says that "it answers for smoking but not for chewing" ; $\ddagger$ and, in my time, I have heard similar opinions passed concerning it by tobaccousers. Lately, the cultivation of this tobacco has been greatly neglected, as the Indians obtain an article from the whites which they prefer. It is but recently that any of them have

* Long, vol. i, p. 449.

† Lewis and Clarke say " two different species of tobacco", p. 76.

$\ddagger$ p. 73. 
learned to chew tobacco. All the men smoke; but the use of the pipe is very rare among the women. These Indians seldom use tobacco alone, but mix it with the dried inner bark of one or more species of dogwood, Cornus stotonifera and $C$. sericea. (See Ope and Opehaśa in Dictionary). They also mix with it the leaves of the Eleagnus argentea, which grows in Northern Dakota, and the leaves of a variety of Arctostaphylos uva-ursi. Sometimes they smoke the dogwood-bark alone, without any mixture of tobacco. Often they put a fragment of castoreum on top of the tobacco before lighting the pipe. The various points of ceremony and etiquette connected with smoking are the same with these tribes as with other western Indians; and they have been described by many observers.

\$16. Inter-tribal trade.-In former days, there was a trade carried on between these tribes and their Indian neighbors: Of late years, it has greatly diminished, but it still exists to some extent.

With the nomadic tribes around, they exchanged their agricultural produce for horses, and, recently, for robes. When the Dakotas saw a certain flower (Liatris punctata) blooming on the prairie, they knew that the corn was ripe, and went to the villages of the farming Indians to trade. From the time they came in sight of the village to the time they disappeared, there was a truce. When they had passed beyond the bluffs, they might steal an unguarded pony or lift a scalp, and were in turn liable to be attacked.

The straight, slender spruce-poles, which form the frames of their skin-lodges, are not obtained in the immediate neighborhood of the Missouri, but are cut in and near the Black Hills, many days journey from Fort Berthold, and in the country of the inimical Teton-Dakotas. The Berthold Indians, consequently, purchase them of the Dakotas, giving a good buffalo-horse, or its equivalent, for the number sufficient for a lodge, about a dozen.

To tribes less skilled than were they in catching wareagles, they traded the tail-feathers of these birds; a single tail being worth a buffalo-horse. Their principal standard of 
value was a buffalo-horse, $i$. e., a horse swift enough to outrun a young adult buffalo in the fall.

It appears probable that they once carried on a trade indirectly with the tribes of the Pacific coast, for they had Dentalium shells similar to those obtained on the Pacific, and they prized them so highly that the white traders found it advisable to obtain them for the trade. As late as 1866 , ten of these shells, of inferior size, costing the traders only a cent apiece, would buy a superior buffalo robe, and formerly only two or three of the same quality were paid for a robe. Modern traders, with whom the writer has conversed, obtain their shells from eastern importers, and know nothing of the original source of supply. They suppose them to come from the Atlantic coast or the Great Lakes, and call them "Iroquois shells", which is probably their corruption of the Chinook "hyakwa"; but it is possible the reverse is the case.

They also used, and still use, as ornaments, fragments of the Abalone shells (one or more species of Haliotis) of the Pacific. These are now supplied to the trade under the name of California shells. Ten years ago, one of these shells, unpolished, sold for a good robe. There is little doubt that they used Abalone, Dentalium, and other sea-shells before the traders brought them. Old traders and old Indians say so. Even as late as 1833 , it would seem that they had not yet become a regular part of a trader's outfit; for Maximilian says of the Mandans:- "They do not disfigure the bodies; only they make some apertures in the outer rim of the ear, in which they hang strings of beads, brass, or iron rings of different sizes, or shells, the last of which they obtain from other Indian tribes. If they are questioned respecting these shells, they answer that they were brought from the sea."*

$\oint 17$. Intercourse with whites.-In a recent little work entitled O-kee-pa, George Catlin says:- "Two exploring parties had long before visited the Mandans, but without in any way affecting their manners. The first of these, in 1738, under the lead of the brothers Verendrye, Frenchmen, who afterward ascended the Missouri and Saskatchewan to the Rocky Mount-

* p. 337. See also p. 338, "White dentalium shells." 
ains ; and the other, under Lewis and Clarke, about sixty years afterward."* He does not tell us where the account of the expedition of 1738 is to be found; he gives us no further evidence on this point; and, as no other mention of the journey has: ever been seen by me, it will receive no further consideration in this essay.

In a letter published in Schoolcraft's Information respecting... the Indian Tribes, the writer, D. D. Mitchell, says, speaking of the Mandans:- "The early portion of their history I gather from the narration of Mr. Mackintosh, who, it seems, belonged to, or was in some way connected with, the French trading company as far back as 1772 . According to his narration, he set out from Montreal in the summer of 1773 , crossed over the country to the Missouri River, and arrived at one of the Mandan villages on Christmas day." $†$ I have never seen Mackintosh's account, nor have I seen any more extensive notice of it than the one given by Mr. Mitchell; and from this, it does not appear that Mackintosh visited any of these agricultural Indians except the Mandans.

There is. every probability that some of these tribes received occasional visits from white traders and adventurers a century or more ago. It may be safely stated that every one of the bands represented in the Berthold village were visited by whites at least eighty years ago, and that they have been in constant communication with representatives of civilized races ever since. In 1804, British traders and French or Canadian interpreters were found in their camps; and the travelers of that year speak of "those who visited them in 1796". $\neq$ Prince Maximilian, writing in 1833, says of "Charbonneau, who was interpreter for the Manitari language", that he "had lived thirtyseven years in this part of the country"; $\$$ that, at his first arrival, the Knife River villages stood precisely where they were in 1833; and that Charbonneau "immediately took up his residence in the central one".\| From these statements we must conclude that Charbonneau settled among the Hidatsas about seventy-nine years ago; and old men of the tribe say that he

* p. 4.

tPart third, p. 253.

\&. 318.

$\ddagger$ Lewis and Clarke, p. 96 .

|l p. 321. 
was not the first white man to come to their towns, yet that few preceded him.

It is likely that all the Europeans who came to these tribes in the early days were from the Hudson Bay Territory, and that they were mostly traders; but, in 1804, it seems that there were some whites sojourning in their country as hunters and trappers. The British fur-companies held the trade of these Indians until 1807,* when Manuel Lisa, who afterward founded the Missouri Fur Company, ascended the river in keel-boats to the Mandan villages and beyond. Until 1832, goods were brought up the. Missouri chiefly in keel-boats or Mackinawboats, which were cordeled or towed by men, with great labor, against the rapid current of the river. Two summers, at least, were always occupied in dragging a boat from Saint Louis to the head of navigation; the crew sustaining themselves chiefly by hunting. In 1832, the first steamer reached the Mandan villages, and after that, for about thirty years, but one or two steamers a year went thus far up the river.

Although these Indians have so long known the whites, it is only within the last twelve or thirteen years that our intercourse with them has been sufficiently extensive to materially modify their customs and ideas. Previously, excepting two or three small military expeditions and an occasional traveler, the only whites they saw were the few connected with the fur-trade; and these persons, as a rule, sought to produce no change in the Indian, but, on the other hand, learned the Indian languages, adopted Indian customs, and endeavored to assimilate themselves to the Indians as much as possible, often vying with one another in their efforts to become amateur savages. Before the period to which I refer, we had traded to them woven fabrics and many trinkets of little value, had taught them the use of fire-arms and iron tools, had given them an opportunity for acquiring a taste for coffee and ardent spirits, but, in other respects, had wrought little change in their minds or manners. Eight years ago, they knew nothing of the use of money, and nothing of the English language except a few oaths and vulgar expressions, which the

* "He set off in the spring following the return of Lewis and Clarke" (Bracken ridge, p. 90). 
more docile had learned. The conservatives were still much the same as their grandfathers were.

In 1863, and during the two following years, ir consequence of the Sioux outbreak of 1862 , large military expeditions visited Fort Berthold, passing through the country of these Indians, and strong garrisons were established in their neighborhood, which are still retained. About this time too (1863), the emigration to the Montana gold-mines by way of the Missouri River began; and, instead of one steamer a year ascending the river as in the old days, they came up by dozens, some making two and three trips during the season of navigation. The Indians were thus brought into more intimate contact with the Americans, the seclusion of their country was ended, and a change more general and rapid in their affairs initiated. Since then, their game has been killed off, they have grown weaker, poorer, and more dependent, and, in many other respects, they have altered for the worse. As yet, no sustained effort has been made to Christianize them; and but little lias been done to advance them in civilization. On the other hand, they have, according to some standards of excellence, bettered in many respects. They have of necessity given increased attention to the cultivation of the soil. The men, as before stated, have learned to perform labor, which, in earlier days, they deemed degrading. Many of their savage customs and ideas have been abandoned; and many of their ceremonies have been simplified or have fallen into disuse. They are generally less superstitious than they were ten years ago, and more skeptical with regard to their old myths.

Since 1866, a large number of their men have enlisted as scouts in the military service of the United States, and have been improved by the discipline of the camp. They have learned the responsibilities, and have done splendidly in the capacity of soldiers; many of them having heroically laid down their lives in our service.

During a short period of their history, the Arickarees were at war with the Americans; but for many years they have strictly maintained peace, and have fought with us and against our enemies. The Mandans and Minnetarees claim never to 
have shed a white man's blood, although some of their number have been killed by whites. For their fidelity they have been repaid in starvation and neglect. Many of these friendly Indians, particularly among the Arickarees, have, during the past ten yèars, died of actual hunger or the diseases incident to a state of famine. Within the past three years there seem to be some evidences of increased legislative interest in them, but the benefits arising therefrom are by no means equal to their needs or their deserts. 


\section{P A R T I.I.}

THE HIDATSA TRIBE.

$\$ 18$. Names of the tribe.-Grosventre.-The people whose language is discussed in the accompanying grammar are commonly called, on maps, in official reports, and by white men in the Indian country, Grosventres. This was a name given to them by the early French and Canadian adventurers. The same name was applied also to a tribe, totally distinct from these in language and origin, which lives some hundreds of miles west of Fort Berthold; and the two nations are now distinguished from one another as Grosventres of the Missouri and Grosventres of the Prairie, names which would lead a stranger to suppose that they were merely separate divisions of one tribe.

In the account of Edward Umfreville, who traded on the Saskatchewan River from 1784 to 1787 , we find mention of a tribe of Indians who lived near the falls of the south branch of the Saskatchewan, and whom he calls "Fall Indians". But he remarks :- "In this people, another instance occurs of the impropriety with which the Canadian French name Indians. They call them Grosventres, or Big-Bellies; and without any reason, as they are as comely and as well made as any tribe whatever, and are very far from being remarkable for their corpulency." * The tribe to which he refers is doubtless that which is now known as the Atsinas, or Grosventres of the Prairie. The similarity of the Canadian misnomers in all probability led Captain Lewis, in 1804, to speak of the Minnetarees on the Missouri as "part of the great nation called Fall Indians". $\dagger$ Comparing our Hidatsa words with their synonymes in Umfreville's Fall Vocabulary, or Dr. Hayden's later Atsina Vocabulary, we can discover no affinity between the Fall and Hidatsa tongues.

Umfreville's remarks concerning the impropriety of the 
name Grosventre would apply as well to those "of the Missouri" as to those "of the Prairie". Maximilian says of the Hidatsa :"The French give them the singular name of Grosventres, which is no more appropriate to them than to any other of the Indian tribes." * Palliser remarks :- "They are most absurdly termed Grosventres by the French traders, there being not the slightest foundation for branding them with that epithet." + Various writers who have visited this tribe concur in these opinions.

Minnetarees. - In the works of many travelers they are called "Mimnetarees", a name which is spelled in various ways; thus Captain Lewis writes it "Minnetarees"; Catlin, "Minatarees"; De Smet, "Minataries"; Palliser, "Minitarees"; while in the accompanying Dictionary it is spelled Minitari, or Miditadi. This, although a Hidatsa word, is the name applied to them, not by themselves, but by the Mandans; it signifies to cross the water, or they crossed the water. The name may allude to the Hidatsa tradition of their own origin, or to their account that they came originally from the northeast, and had to cross the Missouri before reaching the old Mandan villages, which were on the west bank of the river, or the name may have originated from some other cause; but the story, be it true or false, which is now given by both tribes concerned, to account for its origin, is this: When the wandering Minnetarees first reached the Missouri and stood on the bank opposite to one of the villages of the Mandans, the latter cried out, "Who are you?" The strangers, not understanding what was said, but supposing that the Mandans (who were provided with boats) asked them what they wanted, shouted in return, "Minitari," to cross the water, or "Minitari mihats," we will cross the water. The Mandans supposed that in this reply the visitors gave them their name, and called them Minitari ever after.

'The name, as above intimated, will be found in this dictionary written 'Miditadi' or 'Minitari,' and its component parts, 'midi,' water, and 'tadi,' to cross over. The reason for this varying orthography will be discovered by consulting the grammar, paragraphs 19 to 23 inclusive, where it is shown 
that $d, l, n$, and $r$, are interchangeable consonants. Prince Maximilian writes the word Manitari (adding à plural ending), which represents a way in which the Mandans often pronounce it-the Mandan word for water being mani.

Hidatsa was the name of the village on Knife River farthest from the Missouri, the village of those whom Lewis and Clarke considered the Minnetarees proper.* It is probable that after the epidemic of 1837 the survivors of the other villages moved thither, or that the majority of all the survivors came from Hidatsa, which then lent its name to the whole tribe-a name now generally used by this people to designate themselves, and for which reason the one most frequently employed in this essay.

The origin of the word Hidatsin is obscure. It is said by some to mean willows; but I know of no species of willow that bears this name. By a few of the tribe it is pronounced Hidaátsa, and in this form bears a slight resemblance to the word midahádsa, the present Minnetaree generic name for all shrub willows. It may possibly be an old form of the latter word; but, according to my present knowledge of the formation and phonetic changes of this language, I have no reason for believing it to be so.

There is little doubt that the tribe, or a portion of it, was once called Willows; and this may be the reason why some suppose Hidatsa to mean willows. But it is evident that even in former days travelers or their interpreters were uncertain with regard to the application of the name Willows, and later inquiries on the part of the writer have done little toward clearing the difficulty. In Lewis and Clarke's journal (1804), we find the inhabitants of Amatiha, the first village on Knife River above its mouth, spoken of as "Minnetarees Metaharta, that is, Minnetarees of the Willows"; $\dagger$ while Prince Maximilian (1834) says that Hidatsa, or the village on Knife River farthest from the Missouri (above Amatilia), was called "Eláh-sa (the village of the great willows)." $\ddagger$ It is plain that "Eláh-sa" is but a form of Hidatsa, for the aspirate is often pronounced or heard indistinctly; $d$ and $l$ are interchangeable with one 
another in this language (see Grammar, II 20, 22), and $s$ is often used for $t s$, (see I 17). "Metaharta" represents possibly an old or dialectic form of "midahadsa", willow, which was mispronounced by the interpreter, and spelled from his mispronunciation by Captains Lewis and Clarke in an ill-devised way.

Other names.-Hewaktokto, the name of this tribe in the Dakota language, I have heard translated Dwellers on a Ridge; but I think the correctness of this translation may be questioned. Some of the Hidatsa believe that the appellation belonged originally only to the Amahamis, whose name signifies mountain.

In the Arickaree language, the Hidatsa are called Witetsaán. I have heard this rendered in two ways, viz, Welldressed People and People at the Water; the latter said to refer to their old residence at the ford of Knife River.

By the Crows, they are called Amasì, signifying earthen houses or "dirt lodges", as the Upper Missouri interpreters would say.

\$19. History.-These Indians relate of themselves as follows: They originally dwelt beneath the surface of a great body of water, situated to the northeast of their present home. From this subaqueous residence some persons found their way out, and, discovering a country much better than that in which they resided, returned and gave to their people such glowing accounts of their discoveries that the whole people determined to come out. Owing to the breaking of a tree, on which they were climbing out of the lake, a great part of the tribe had to remain behind in the water, and are there yet. After coming from the water, they began to wander over the prairies, and sent out couriers to explore the country around. Those who were sent to the south returned after a time with tidings of a great river and a fertile valley, of a nation who dwelt in houses and tilled the soil. They brought back with them, too, corn and other products of the country. Toward this promised land the tribe now directed its steps, and, guided by the couriers, they reached in due time the Mandan villages on the Missouri. When they arrived, however, instead of putting to death the newly-found people, they encamped quietly beside 
them, learned of them the arts of peace, and have ever since dwelt near them.

From the descriptions of their life previous to rising from the lake, it would seem as if their tradition originally mentioned an insular home or a home beyond some great body of water. The story of their coming ip out of the lake, and of the breaking of the tree by which they rose, resembles so much the Mandan tradition as to lead us to believe that one nation borrowed its legend of the other, or that the two legends sprung, at no very remote time, from a common source. Some of the modern story-tellers say that the Minnewakan, or Devil's Lake, in Northern Dakota is the natal lake of the tribe. The Hidatsa call it Midihopa, which, like the Dakota name, signifies sacred, or mysterious water.

'This account of their origin they tell usually as one story; but they have, besides, a voluminous account of what happened to them during their long wanderings on the prairie, from the time they left the lake until they reached the Mandan village, which account is embodied in a separate tale-the almost interminable legend of Itamapísa, the proper recital whereof, by an old story-teller, occupies three or four long winter-evenings. In this tale, it is said that they were often on the eve of death by starvation, but were rescued by a miraculous supply of buffalo-meat. Stones, they say, were strewn upon the prairie obedient to a divine order, and firom them sprang to life the buffalo which they slaughtered. It was during these years of wandering, as the legend relates, that the spirit of the sun took a woman of this tribe up into the sky. In the course of time, she had a son, who descended to the earth, and, under the name of Itamapísa, or Grandchild, became the great prophet of his mother's people.

It might be more proper to introduce such tales elsewhere than under the head of history, but, perhaps, a scrap of historical truth may be picked from them, which is, that the Hidatsa were once a tribe of nomadic hunters, alternately starving and feasting as game was scarce or abundant, and that, since a comparatively recent date, they have settled in the neighborhood of the Missouri and become farmers by in- 
tercourse with tribes who previously tilled the soil. There are many circumstances which seem to corroborate this. It may be remarked, too, that the stories from which the above items are taken are believed by these Indians to be true, while many other tales, just as plausible as these, they declare to be purely fictional.

There are two affluents of the Missouri, named Knife River. One of these enters from the north, above Fort Berthold; the other from the west, below Fort Berthold. It was upon the banks of the latter stream that the former homes of this people stood. At least as early as A. D. 1796, there were three villages on Knife River. The first and largest, named Hidatsa, was on the north bank, about three miles from the Missouri, and was the home of a people whom Captains Lewis and Clarke, for some reason, regarded as the Minnetarees proper. The second village, named Amatilia, half a mile above the mouth of Knife River, and on the south bank of the stream, was the home of a people very closely allied to the inhabitants of Hidatsa, who spoke a language nearly but not exactly the same as that of the former, and had a separate chief, who seemed to acknowledge to some extent the authority of the chief of the upper village. The third village, named Amakami or Mahaha, was at the mouth of Knife River, on the south side, and was occupied, as before mentioned, by the Amahamis (see $\$ 11$ ), a people allied to those of Hidatsa, but more remotely than the dwellers in Amatiha. The present Hidatsa or Minnetaree tribe of Fort Berthold consists of the survivors of these three villages and their descendants, with, perhaps, representatives of some small wandering bands of allied Indians which no longer exist as organized tribes. Lewis and Clarke seem to speak very positively of wandering Minnetarees, hunting in the neighborhood of Knife River, ${ }^{*}$ and not considered as part of the Crow nation. In 1796, the Mandans were near neighbors of the Minnetarees, living some four miles south of the latter, in three villages, which in 1804 were found reduced to two.

Some forty years before the coming of Lewis and Clarke, 
$i$. e., about the year 176t, the Amahamis and the people of Amatilia dwelt farther south, in the neighborhood of Heart River, along with the Rees and Mandans; and it is likely that the people of Hidatsa lived there at the same time, or at an earlier date.

At one time, the Crows and the Hidatsa (under which term I will now include all the bands represented in the present tribe) lived in close proximity to one another, and constituted one nation; not, probably, one consolidated tribe under a single chief, but independent and allied bands, making common cause against other races, and speaking slightly different dialects, like the various bands of the Dakota nation to-day. In the course of time, the Crows, in two bands, separated from the Hidatsa, and moved farther to the south and west, becoming estranged from the latter but not inimical to them. This separation took place, doubtlessly, more than one humdred, and probably not less than two hundred, years ago.

'The Hidatsa and Crow legends agree closely concerning the secession of the Crows, and their story is essentially as follows: During a season of scarcity, while portions of both peoples were encamped together, a single buffalo came in the neighborhood of the camp and was killed by some of the Hidatsa, who offered the paunch to the Crows. The latter, considering the offer illiberal, refused it, and a misunderstanding ensued, which resulted in separation. The Hidatsa have ever since called the Crows by the name of Kihatsa, or they (who) refused the paunch. (See kiliatsa in Dictionary.) It may reasonably be doubted that such an incident as this, of itself, and without previous disagreements, would have been sufficient to have alienated these bands from one another; yet it is not improbable, if, as some say, there was, among the party of slighted Crows, a very proud and powerful chief, who regarded the action of the Hidatsa humters as a personal insult. It is more likely, however, that they parted in consequence of some general misunderstanding concerning the division of game (and other matters perhaps), which may have culminated in some particular quarrel. There is no good reason for supposing the legend to be without foundation in fact. Laws con- 
cerning the distribution of game are often unlike in different bands. Cases sometimes arise, too, which their laws do not cover, and grave disputes occur in consequence. The legend and the name Kihatsa seem to have some allusion to the Hidatsa manner of dividing game. When two members of this tribe kill a buffalo, one takes the hind quarters and hump, and is said to "take the back"; the other takes the rest of the forequarters and the entrails, and is said to "take the paunch". During the years 1804, 1832, 1833, and 1834, we have the evidence of travelers that the three Knife River villages remained just where they stood in 1796 , and it is said by the Indians that there was no change until some time after the epidemic of 1837, when the survivors of the three villages formed themselves in one on Knife River. There they remained until 1845, when the Hidatsa (and about the same time the Mandans-see $\oint 10$ ) moved up the Missouri, and established themselves where their permanent village now stands, some thirty miles by land and sixty by river from their old home. Here, as before stated, they were joined by the Arickarees in 1862 .

It may be well here to give some account of the tradingpost, which has lent its name to the village and the locality. In 1845, soon after the Hidatsa settled here, the American Fur Company began, with the assistance of the Indians, to build a stockaded post, which they called Fort Berthold, in honor of a $\mathrm{Mr}$. Berthold of Saint Louis. In 1859, an opposition trading company erected in the village some inclosed buildings, which they named Fort Atkinson. In 1862, the opposition ceased, and the American Fur Company obtained possession of Fort Atkinson, which they then occupied, transferring to it the name of Fort Berthold. They abandoned the old stockade, which was afterward (December 24, 1862) burned by a warparty of Sioux, who attacked the village. One side of the newer fort still stands, and is occupied by the Indian agency; the other three sides having been burned down October 12, 1874.

$\S 20$. Character. - To illustrate the character of the Hidatsa, I present, first, a few extracts from the writings of 
other observers, placing them in chronological order of observation. Some of the quoted writers visited this tribe in the most prosperous period of their history, others in later and unhappy days; yet their opinions are not at variance with one another.

1832.- "There is no tribe in the western wilds, perhaps, who are better entitled to the style of warlike than the Minatarees; for they, unlike the Mandans, are continually carrying war into their enemies' country ; oftentimes drawing the poor Mandans into umnecessary broils, and suffering so much themselves in their desperate war-exeursions that I find the proportion of women to the number of men as two or three to one through the tribe."-Catlin, N. A. Indians, vol. I, p. 187.

"This day's ramble showed us all the inhabitants of this little tribe, except a portion of their warriors, who are out on a war-excursion against the Riccarees; and I have been exceedingly pleased with their general behavior and looks, as well as with their numerous games and amusements, in many of which I have given them great pleasure by taking a part."Ib., p. 199.

1834._ "The Mandans and Manitaries are proud and have a high sense of honor:"-Maximilian, p. 353.

1848._ "The Minataries are a noble, interesting people."Palliser, p. 198.

1851.- "Some days after, we stopped at Fort Berthold, to land some goods at the great village of the Minataries, or Osier tribe, nicknamed the Grosventres of the Missouri." * * * * "The great chief of the latter village, called Four Bears, is the most civil and affable Indian that I met on the Missouri."-De Smet, pp. 76-77.

1854.- "The Grosventres have a large village of mud houses, very unsightly outside, but within warin and comfortable. These Indians are fine specimens of the red man. 'They are industrious, and raise corn enough to supply many of their neighbors with bread. They are well disposed toward the whites."-Report of Commissioner of Indian Affairs for 1854.* 1858._ "I shall ever look back upon the years spent in 
the Indian country as among the pleasantest of my life; and if in all my dealings with white men I had found the same sense of honor that characterized my 'savage' friends, my appreciation of human nature would be much higher."*-Boller, p. vii.

"During the whole time that I lived among the Grosventres, I never missed a single article, although I took no trouble to keep my things out of sight. My house would often be crowded with Indians; sometimes only one or two would be present; yet if called away I felt satisfied that on my return I would find everything just as I left it."-Ib., pp. 239, 240 .

1862.- "They [Grosventres and Mandans] are a good people; peaceable, reliable, and honest. They keep as far as is possible the treaty made at Laramie."-Report of Commissioner of Indian Affairs for 1862, p. 194.†

I can indorse the above opinions, and can say that the Hidatsa are to-day, for Indians, examples in industry, general morality, forethought, and thrift.

\$21. Appearance-More than forty years ago we find the general appearance of these Indians thus described by a careful observer:- "The Manitaries are in fact the tallest and best-formed Indians on the Missouri, and, in this respect, as well as in the elegance of their costume, the Crows only approach them, whom they perhaps even surpass in the latter particular." $\ddagger$ "The Manitaries do not differ much in personal appearance from the Mandans; but it strikes the stranger that they are in general taller. Most of the men are well-formed and stout; many of them are very tall, broad-shouldered, and muscular; the latter may, indeed, be said of the greater proportion of the men. Their noses are more or less arched and sometimes straight. $\quad * \quad * \quad * \quad$ The women are much like the Mandans; many of them are tall and stout, but most of them short and corpulent. There are some pretty faces among them, which, according to the Indian standard of beauty, may be called handsome."§

*From preface. These remarks seem to refer more particnlarly to the Grosventres and Mandans, with whom the author spent the greater part of the time that he lived "among the Indians".

t Report of Agent, S. N. Litta to the Commissioner.

$\ddagger$ Maxinuilian, p. 179 .

§ $I b .$, pp. 395, 396. 
At the present day, it can hardly be said that they are of finer physique than the Tetons and other roving bands of the Upper Missouri, who have suffered less, of late, from epidemic disease and hunger, but they still take greater pride in their dress and personal appearance than. most of their neighbors. The frequent intermarriages of the Mandans and Hidatsa tend constantly to assimilate them more and more to one another in appearance; yet those claiming pure Hidatsa blood are generally taller and of more prominent features than those who consider themselves pure Mandans. We do not see as many faces among the Mimnetarees pitted with small-pox as among the Arickarees and Mandans. Among all the tribes in the village, there are many disfigured by goiter and opacities of the cornea. All of the Hidatsa men bear on their bodies unsightly cieatrices resulting from the tortures of the Nalipike.

Tattooing may be spoken of in this comnection. A few only of the old men are tattooed. The marks consist of numerous parallel bands on one side, or over the entire of the chest and throat, and over one or both arms. I have never seen tattooed marks on any of this tribe elsewhere, or in any other shape. The middle-aged men, the young men, the women, and the children are not tattooed. I believe that these marks on the old men were put on for something more than mere ornament, and had some forgotten significance. In Arickaree picturewritings, Grosventres are sometimes represented by a rude symbol of a man having the upper part covered with parallel stripes. As far as I can learn, this particular style of tattooing is peculiar to the Minnetarees.

Complexion - The majority of the Hidatsa have the ordinary dusky Indian complexion, which is, however, not, of a uniform shade, as far as I have seen, in any tribe. There are none of this nation that would be considered dark for Indians. Among various tribes of western Indians may be found individuals, claiming pure aboriginal blood, who possess complexions much fairer than the average Indian, with light-colored hair and eyes. Such individuals are more common among the Mandans and Mimnetarees than they are among most of the neighboring tribes. A natural or inherited clearness of com- 
plexion, too, is more easily discernible among members of the village tribes than among members of roving bands who are more exposed to the weather. The presence of pale Indians in these tribes was noted by travelers in early days, before intermarriages with whites were common enough to have accounted for it.

Lewis and Clarke* and Gasst notice this fairness when speaking of the Mandans only, but their remarks are general. Catlin speaks of the fairness of the Mandaus only, and supposes this peculiarity to arise from some pre-Columbian infusion of European blood.f 'The Prince of New Wied, who visited these tribes but one year later than Mr. Catlin, denies that the Mandans are of fairer complexion than their neighbors, $\$$ while he asserts, at the sume time, that, "after a thorough ablution, the skin of some of them appear's almost white." I I have heard old Mandans say that when the Minnetarees, including the Crows, first came among them, the strangers were a fairer race than they. Of the Crows, who, as before shown, once formed one nation with the Hidatsa, Colonel Raynolds, in his Report of the Exploration of the Yellowstone (1859), p. 48, says:- "The Crows are fairer than the Sioux, many of the mountain band being sallow and hardly a shade darker than whites who undergo similar exposure. This fact was so marked that the first seen were supposed to be half-breeds, but we were assured that they were of pure Indian descent."

It is not necessary to suppose an intermixture of European blood in order to account for lightness of color in an Indian. There is no reason why marked varieties of color should not arise in the Red Race as it has done in other races of men, and as it has so often done, under cultivation, within specific limits in the lower animals. I have seen full-blooded Indians who were whiter than some half-breeds and whiter than the darkest representatives of the Aryan Race. An increase of hairiness is a more reliable sign of Caucasian blood in an Indian than a diminution of color in the skin; and I never could discover that those fair Indians, claiming pure blood, were more hairy than others. The fairness of which I speak is not albinism,

$$
\text { * p. } 89 . \quad \dagger \text { p. } 83 . \quad \ddagger \text { Okeepa, pp. 5, 42. \$ p. 3j4. \| p. 33\%. }
$$


for the eyesight of the fair Indians is as perfect as that of the dark; 'they have no unusual appearance of the pupil, and exposure to simlight darkens their skins. I have never seen an albino Indian.

Among various western tribes, individuals may be found who are characterized, even in childhood, by having coarse gray hair. From all I could see and learn, I should think that such persons are more numerous anong the Himnetarees and Mandans than in any other tribe; and they are perhaps the most numerous among the Mandans.

522. Ceremonies.-Their most important ceremony is that of the Dahipike or Nahpike, which formerly took place regularly once a year, but is now celebrated every second or third year only. On the day when it is determined to commence this ceremony, some men of the Hidatsa tribe, dressed and momnted as for a war-party, proceed to the woods. Here they select a tall, forked cottonwood, which they fell, trim, and bark; to this they tie their lariats, and, by the aid of their horses, drag it toward the village. In the procession, the man who hais most distinguished himself in battle, mounted on the horse on whose back he has done his bravest deeds, takes the leal; other's follow in the order of their military distinction; as they drag the log along, they fire their gums at it, strike it with their sticks, and shout and sing songs of victory. The log, they say, is symbolical of a conquered enemy, whose body they are bringing into the camp in triumph. When the $\log$ is set up, they again go to the woods to procure a quantity of willows. A temporary lodge of green willows is then built around the log, as the medicine-lodge, wherein the ceremony is performed. The participants fast four days with food in sight, and, on the fourth day, submit to tortures which vary according to the whim of the sufferer or the advice of the medicine-men. Some have long strips of skin separated from different parts of their bodies, but not completely detached. Others have large pieces of the integument entirely removed, leaving the muscles exposed. Others have incisions made in their flesh, in which raw-hide strings are inserted; they then attach buffalo skulls to the strings and run round with these until the strings become 
disengaged by tearing their way out of the flesh. Others, again, have skewers inserted in their breasts, which skewers are secured by raw-hide cords to the central pole, as in the Dakota sun-dance; the sufferer then throws himself back until he is released by the skewer's tearing out of the flesh. Many other ingenious tortures are devised. In the narrative of Long's Expedition to the Rocky Mountains, we find an account of the latter part of this ceremony,* prepared probably from the statements of Mr. Dougherty or Mr. Lisa, as the expedition did not go near the Minnetaree country. All of the torments there described, and more, are inflicted to this day. Among them is the following:- "Another Minnetaree, in compliance with a vow he had made, caused a hole to be perforated through the muscles of each shoulder; through these holes cords were passed, which were, at the opposite ends, attached by way of a bridle to a horse, that had been penned up three or four days without food or water. In this manner he led the horse to the margin of the river. " The horse, of course, endeavored to drink, but it was the province of the Indian to prevent him, and that only by straining at the cords with the muscles of the shoulder, without resorting to the assistance of his hands. And notwithstanding all the exertions of the horse to drink, his master succeeded in preventing him, and returned with him to lis lodge, having accomplished his painful task." $\dagger$

In describing the Mimnetarees, Prince Maximilian says that they lave the Mandan ceremony of the Okipa or O-kee-pa, with some modifications, and call it Akupehi. At this time, the Hidatsa call the Mandan ceremony Akupi (of which word probably Akupehi is an old form); but they apply no such term to their own festival. Maximilian did not spend a summer among those Indians, and, therefore, knew of both ceremonies only from description. If the Minnetaree festival to which he referred was, as is most likely, the Nahpike, he is, to some extent, in error. 'The rites resemble one another only in their appalling fasts and tortures. In allegory, they seem to be radically different.

The minor ceremonies are chiefly those connected with their 
bands, of which the men and women have separate organizations and separate ceremonies.* Rites commected with the eagletrapping will be noticed hereafter. In one of his letters descriptive of the Mimnetarees, Catlin gives an account of a greencorn dance, $\dagger$ and devotes a plate to illustrating the same. $f \mathrm{He}$ does not directly say that this is a Mimmetaree festivity, but introduces the description in a way calculated to lead the casual reader to suppose that it is such. I have shown the plate to several of these Indians, and have given them the description of the dance, but have been invariably informed that they never had such a ceremony. In the same letter, he speaks of an improvirlent waste of the harvest in gluttonous eating of the green corn. His remarks on this point certainly do not apply to the Hidatsa. In Chapter XIII of his work, Boller gives a brief description of a dance or parluididi performed by the Goose Band, an organization of the old women of this tribe; and, in Chapter XIX, he describes certain ceremonies of the White Cow Band. The latter band, originally, I believe, belongs to the Mandan women, but Hidatsa women are now admitted to its mysteries.

5 23. Mrinolog Axn stperstrions.-Oljects of veneration.-The object of their greatest reverence is, perlaps, Itsikamahidis, the First Made, or First in Existence. They sometimes designate him as Itakatétas, or Old Man Immortal. Some Indians say that itsikamahidis means he uho first made, but such a rendering is not in accordance with the present etymology of the langmage. 'They assert that he made all things, the stars, the sm, the earth, and the first representatives of each species of animals and plants, but that no one marle him. He also, they say, instructed the forefathers of the tribes in all the ceremonies and mysteries now known to them.

Mahopa, or Mahopa-ictias, is the equivalent in the Hidatsa language for those terms in other Indian tongues which are usually translated "The Great Spirit". In this language, it may be (figuratively, perhaps) applied to the Itakatetas, or any-

* See icke, iliokaicke, ilokamiaicke, masukaicke, masukakadista, masukamadaki, midaicke, and paduididi, in the Dictionary.

†p. 189.

$\ddagger$ Plate 75. 
thing else of a very wonderful or sacred nature. Much diversity of opinion exists among observers of Indian character concerning the ideas which the savages attach to this term; and the subject deserves more consideration than it has yet received. The ideas of all the tribes within our borders have undoubtedly been greatly modified by intercourse with the whites; and, recognizing this fact, many claim that the Great Spirit, or, more properly, Great Mystery, is a deity of the modern Indian only. I have certainly heard some old and very conservative Minnetarees speak of Mahopa as if they meant thereby an influence or power above all other things, but not attaching to it any ideas of personality. It would now be perhaps impossible to make a just analysis of their original conceptions in this matter. But the Old Man Immortal has no vague existence in their minds.

If we use the term worship in its most extended sense, it may be said that, besides this being, they worship everything in nature. Not man alone, but the sum, the moon, the stars, all the lower animals, all trees and plants, rivers and lakes, many bowlders and other separated rocks, even some hills and buttes which stand alone-in short, everything not made by human hands, which has an independent being, or can be individualized, possesses a spirit, or, more properly, a shade. (See idahi in Dictionary.)

To these shades some respect or consideration is due, but not equally to all. For instance, the shade of the cottonwood, the greatest tree of the Upper Missouri Valley, is supposed to possess an intelligence which may, if properly approached, assist them in certain undertakings; but the shades of shrubs and grasses are of little importance. When the Missouri, in its spring-time freshets, cuts down its banks and sweeps some tall tree into its current, it is said that the spirit of the tree cries while the roots yet cling to the land and until the tree falls into the water. Formerly it was considered wrong to cut down one of these great trees, and, when large logs were needed, only such as were found fallen were used; and to-day some of the more credulous old men declare that many of the misfortunes of the people are the result of their modern disre- 
gard for the rights of the living cottonwood. The sun is held in great veneration, and many valuable sacrifices are made to it.

Future state.-They believe neither in a hell nor in a devil, but believe that there are one or more evil genii, in female shape (see mahopamiis in Dictionary), who inhabit this earth, and may harm the Indian in this life, but possess no power beyond the grave. Their faith concerning a future life is this: When a Hidatsa dies, his shade lingers four nights around the camp or village in which he died, and then goes to the lodge of his departed kindred in the Village of the Dead. When he has arrived there, he is rewarded for his valor, self-denial, and ambition on earth by receiving the same regard in the one place as in the other; for there, as here, the brave man is honored and the coward despised. Some say that the ghosts of those who commit suicide occupy a separate part of the village, but that their condition differs in no wise from that of the others. In the next world, human shades hunt and live on the shades of buffalo and other animals that have here died. There too there are four seasons, but they come in an inverse order to the terrestrial seasons. During the four nights that the ghost is supposed to linger near his former dwelling, those who disliked or feared the deceased, and do not wish a visit from the shade, scorch with red coals a pair of moccasins, which they leave at the door of the lodge. The smell of the burning leather, they claim, keeps the ghost out; but the true friends of the dead man take no such precautions.

Various superstitions. - They have a great many superstitious notions, yet I believe their superstitions are neither more numerous nor more absurd than those of the peasantry of some European nations to-day. There is, too, among them every degree of faith in these fancies, from almost perfect skepticism to the most humble credulity. I will not describe all of their superstitions known to me, but will refer, for illustration, to a few of them. They believe in the existence and visibility of human and other ghosts, yet they seem to have no terror of graveyards and but little of mortuary remains. You may frighten children after nightfall by shouting nohidahi (ghost), but will not scare the aged. They have much faith in dreams, 
but usually regard as oracular those only which come after prayer, sacrifice, and fasting. They have queer notions respecting the effects of different articles of diet, thus: An expectant mother believes that if she eats a part of a mole or shrew, her child will have small eyes; that if she eats a piece of porcupine her child will be inclined to sleep too much when it grows up; that if she partakes of the flesh of the turtle, her offspring will be slow or lazy, etc.; but they do not suppose that such articles of food affect the immediate consamer. They have faith in witchcraft, and think that a sorcerer may injure any person, no matter how far distant, by acts upon an effigy or upon a lock of the victim's hair.

It is believed by some of the Hidatsa that every human being has four souls in one. They account for the phenomena of gradual death, where the extremities are apparently dead while consciousness remains, by supposing the four souls to depart, one after another, at different times. When dissolution is complete, they say that all the souls are gone, and have joined together again outside of the body. I have heard a Minnetaree quietly discussing this doctrine with an Assinneboine, who believed in only one soul to each body.

Amulets.-Every man in this tribe, as in all other neighboring tribes, has his personal medicine, which is usually some animal. On all war-parties, and often on hunts and other excursions, he carries the head, claws, stuffed skin, or other representative of his medicine with him, and seems to regard it in much the same light that Europeans in former days regarded-and in some cases still regard-protective charms. 'To insure the future fleetness of some promising young colt, they tie to the colt's neck a small piece of deer or antelope horn. The rodent teeth of the beaver are regarded as potent charms, and aré worn by little girls on their necks to make them industrious.

Oracles.-Since their removal to their present village, they do not seem to have any very important local oracles to consult; but when they lived on Knife River, they had at least two such holy places. One of these was a famous holy stone, or "Medicine rock" (Mihopas, or, Mandan, Miłopinis), which is described by Long and by Maximilian. It was some two or 
three days' journey from their residence. The Hidatsa now seldom refer to it, and I do not think they ever visit it.

The other famous oracle, to which they now often refer, as they have still some fancies connected with it, was the Makadistati, or House of the Infants, a cavern, near the Knife River, which they supposed extended far into the earth, but whose entrance was only a span wide. 'This cave, they say, was inhabited by pigmies, or mysterious infants, who came out only at night, and then with great caution, lest they should be observed, and who followed a wise and watchful leader that knew the scent of man and snuffed the air as he advanced, like the leader of a band of antelope. 'They suppose that if he detected the presence of a human being, he gave the alarm and all retreated. After rainy nights, they saw tracks of some animals going from and returning to the cave, which tracks they said were those of the infants. The oracle was thus consulted: The childless husband, after a long fast, would repair to the neighborhood of the cave at night, and secrete himself behind a bowlder, to the leeward, to watch; if, in his hungerweakened brain, he had a vision of the infants, he returned home, confident that he would be a father within a year. 'The barren wife who desired children would, at sunset, lay at the mouth of the cave a tiny play-ball and a little bow and arrow. If the ball was missing in the morning, she believed that within a year she would be the mother of a girl; while if the bow and arrow were missing, she supposed she would be the mother of a boy. If neither were "taken", she went back with little hope, and could not consult the oracle again until a year had elapsed. There are those among them who imagine that, in some way or other, their children come from the Makadistati; and marks of contusion on an infant, arising from tight swaddling or other causes, are gravely attributed to kicks received from his former comrades when he was ejected from his subterranean home.

An account, given in Long's travels, of a certain hill, which "was supposed to impart a prolific virtue to such squaws as resorted to it", etc., * seems to refer to this oracle; 
but, if such is the case, I believe the account to be incorrect in some respects.

$\oint$ 24. Marriage, etc.-Marriage is usually made formal by the distribution of gifts on the part of the man to the woman's relations. Afterward, presents of equal value are commonly returned by tlie woman's relations, if they have the means of returning them and are satisfied with the conduct of the husband. After the marriage, if the husband is a young man taking his first wife, he becomes an inmate of his fatherin-law's lodge, and helps, by his hunting, to support his wife's parents. Some travelers have represented that the "marriage by purchase" among the Indians is a mere sale of the woman to the highest bidder, whose slave she becomes; but I feel that they misrepresent the custom, unless where their remarks may apply to some modern irregularities among the least reputable persons. Certainly, they misrepresent the custom as it exists in this tribe. The presenting of the wedding-gift is a form. The gift itself is a pledge to the parents for the proper treatment of their daughter, as well as an evidence of the wealth of the suitor and his relations. The larger the marriage-gift the more flattering it is to the bride and her relations; hence, the value of the presents offered has something to do in favoring a suitor's cause; but girls are left much to their own choice in selecting husbands for themselves. Parents sometimes, by persuasion, but rarely by any harsh coercion, endeavor to influence a daughter in the reception or rejection of an offer. I have known many cases where large marriage-presents have been refused from one party, and gifts of much less value accepted from another, simply because the girl showed a preference for the poorer lover. The fame of a man as a warrior, his influence and position in the tribe, do more to secure him a good wife than the presents he may offer. Skill in hunting is a high recommendation; parents commonly advise their daughters to marry the men who will never leave the lodge unprovided with meat. I knew a case of a poor young Mandan, who had a sickly and worthless wife of another tribe, to whom, however, he was very kind; when she died, a well-to-do. Grosventre, who had three fine daugh- 
ters, gave them all to the young widower in marriage, and with them a valuable present in horses and other property, saying, "The young man has a good heart, and will be kind to my children when I am dead." Sometimes when a girl is erossed in her love, she elopes with her favorite. The pair remain out on the prairie for a week or so, and then return to the village. Usually this ends the trouble. They are then considered married, but such marriages are looked upon as undignified, and different terms are applied to a marriage by elopement and a marriage by parental consent. (See kidalie and wahe in Dictionary.)

Polygamy is practiced, but usually with certain restrictions. A man who marries the eldest of several sisters has a claim to the others as they grow up; and in most cases marries them, unless they, in the mean time, form other attachments and refuse to live with him. As certain female cousins are regarded as younger sisters, a man has often much latitude in selecting wives under this law. A man usually takes to wife the widow of a brother, unless she expresses an unwillingness to the arrangement, and he may adopt the orphans as his own children. When a Grosventre takes a second wife who is no relation to the first wife the results are generally unhappy. Sometimes the first wife leaves him and returns to her relations; sometimes she succeeds in chasing the second wife away. Occasionally, if the husband is well off, he provides them with separate establishments; sometimes, again, but rarely, the two wives agree.

Divorce is easily effected; yet, among the better class of people in the tribe, it is rare. A young man who possesses sufficient recommendations to secure a comely and industrious girl of good reputation and well comected is usually in no hurry to part with her, nor is she willing to leave him for trifling causes. The unions of such people often last for life. Among' persons of different character, divorces are common. The Minnetaree woman is, as a rule, faithful to her husband, particularly when she is married to the man of her choice. It sometimes happens, however, that a married woman elopes. The injured husband may then satisfy himself by seizing all the property of the 
seducer and of the seducer's friends that he can lay his hands on, and the latter often give him opportunities of doing so, or voluntarily come forward with presents to appease him. If the husband should at first slay his faithless wife, which is rarely done, no one would call him to account for it; but if he or any of his relations have made seizures or accepted presents on account of the elopement, he does not dare to touch her when she returns. But the most praiseworthy course for the husband to pursue is to send for the runaways, request their return to the village, and, when they come back, invite them to his lodge and formally present the woman to her seducer, giving him a horse or some other valuable gift into the bargain. In short, if he would show that "his heart is strong", he must treat the whole affair as if he had had a good riddance. If a man discards a wife for infidelity, or if she elopes from him, he hopelessly disgraces himself if he takes her back.

Notwithstanding that such are their customs, it must be remembered that their social discipline is not very severe. Punishments by law, administered by their soldier band, they have, but only for serious offenses against the regulations of the camp. He who simply violates social customs of the tribe often subjects himself to no worse punishment than an occasional sneer or taunting remark; but for grave transgressions he may lose the favor and regard of his friends.

With the Minnetarees, as with other western tribes, it is improper for a man to hold a direct conversation with his motherin-law; but this custom seems to be falling into disuse.

\$25. NAmEs.-Children are named when a few days old. Sometimes to males four names are given, all of which will have the same noun, but each one a different adjective. Only one of these names will be commonly used. In after years, the names of the males are changed once, or oftener, or rather new names are given; for they will be called as often by the old names as by the new. The first new name is usually given to a youth after he has first struck an enemy in battle. The names of women are rarely changed. Sometimes, if a name is long, a part of it only is used in ordinary conversation. Nicknames are often given on account of some absurd saying, 
ludicrous circumstance, or personal peculiarity; and it sometimes happens that a person is called by his nickname almost to the exclusion of his proper name. Boys are sometimes named in honor of distinguished warriors deceased. Horses are rarely named; but names are often given to dogs, particularly to such as children keep for pets. White men known to the tribe are ordinarily named by these Indians from personal peculiarities; thus, we have for whites names which translated signify Long Neck, Fish-Eyes, Antelope-Eye, Old Crane, ete. A white man who has been for many years employed at Fort Berthold as an ox-driver, and who has, in consequence of his employment, frequently occasion to say "wo, wo-haw!" is known among the Grosventres as momohas (Englished, Mómohaush or Bobohaush). Whites are sometimes called by the translations of their regular Christian-names or surnames. Thus, an old interpreter named Pierre Garrean is called mis (Englished, Meesh or Beesh), from mi', a rock; and a Mr. Pease, who formerly traded at Fort Berthold, is known to the tribe as amazis (Englished, Amaúzhish), from amazi, beans. It is probable that some of these translations are made by the whites and then employed by the Indians.

I have seen some members of this and of other tribes who are ashamed to tell their names, and when asked for their names will answer reluctantly and with apologies, or seek a third party to give the information; while other Indians, apparently as conservative, exhibit no such hesitancy. I think that sensitiveness on this point is not so common among the Indians at Fort Berthold as among other tribes; nor is it as common among them now as it was ten years ago.

$\$ 26$. Relationship.-To illustrate their system of relationship, some of the Hidatsa names for relations are here synoptically given, although they may be found also in the Dictionary, each in its alphabetical order.

adutáka,-grandfather or great-grandfather, or grandfather's brothers.

ikú,-grandmother, great-grandmother, grandmother's sisters.

atě,-father, father's brothers, uncles in the male line. 
átě-ka'ti, - a true father.

' tatís,-another term for father, never used with the pronouns. line.

íka' or íkạs, -mother, mother's sisters, aunts in the female

hidú, - a true mother (same word as for bone).

hu,-another term for mother, said to be of amahami origin.

it idu, - mother's brothers, uncles in the female line.

isámi, - a father's sisters, aunts in the male line.

itakísa, - a general name for sisters and female cousins, also the only name for a man's younger sister.

itamětsa, - a general name for brother or male cousin, also used in the sense of companion as in English. The only term for a woman's elder brother.

itáku, - a woman's younger sister.

idú,-a woman's elder sister.

itamía, - a man's elder sister.

itsúka, - a man's or woman's younger brother.

íaka,-a man's elder brother.

idísi,-a son, said by both parents.

iká,-a daughter, a brother's daughter.

kidá,-a husband. sister's.

itádamia,-a wife, a wife's sisters, particularly her younger

úa, -a true wife.

isilkísi, - a husband's brother.

idá'ti, - a wife's brother, a brother's husband.

The above terms are for relations of the third person; many of them having the possessive pronoun of the third person ' $i$ ' inseparably prefixed, or to be removed only when pronouns of the first and second persons are used. To make the forms of the first and second persons 'ma' and ' $\mathrm{di}$ ' are respectively substituted for ' $\mathrm{i}$ ', or the fragmentary pronouns ' $m$ ' and ' $d$ ' used. We have thus, mátě, my father; matsuka, my younger brother; dúa, your wife; díaka, your elder brother, etc. 'The words tatis, ika', and hidu do not ordinarily take possessive pronouns, but are the same for all persons. All these may end with s. (See I 90 in Grammar.) 
In the above definitions, male cousins and adopted brothers are included under the term brother, and female cousins and adopted sisters under the term sister. Hence it is evident that their words expressive of relationship are often applied to the most distant and indefinite connections.

On examination of the foregoing list, the following facts may be noted: Of the terms for brother and sister, certain ones are used only for relatives of the male, others only for those of the female; some are applied only to elder, others only to younger relatives; while two of the terms are general. There is a separate term for a maternal uncle, but none for a paternal uncle; he is called by the same name as a father. When they wish to distinguish between an actual father and a father's brothers, they use the adjective ka'ti, true, real, in speaking of the former. While there is a name for paternal aunt, there is none to distinguish maternal aunt from mother; yet there is a special word to designate the real mother, although she is commonly called by the terms which apply as well to her sisters. There are two names for wife; one for a wife by actual marriage, the other for an actual wife as well as what might be called a potential wife, $i . e$., a wife's sisters. There are two terms for brother-in-law, but no general term, as with us.

It must not be supposed, from the wide significance of some of their terms, that they do not discriminate between all grades and conditions of kinship. When they have no single word to define the relationship, they employ two or more words.

$\$ 27$. Huxting.-Their methods of hunting are much the same as those of all the other plain Indians. In former days they made antelope-parks; * they stampeded herds of buffalo over bluffs; they approached animals carefully until within close arrow-range, or decoyed them to approach the hunter by imitative sounds, or, as in the case of antelope, by displaying attractive objects. When they obtained horses, the chasing of the buffalo became common; and when they came into the possession of fire-arms, they began to hunt much as white

" See Lewis and Clarke, p. 92 ; De Smet, p. 148 et 8eq.; Maximilian, p. 385. · Other authors describe this mode of hunting. 
men do. They still often employ the primitive methods; thus, when they find antelope abundant, they make the oft-described antelope-park. The bow and arrow are still largely employed by the hunters; and fall-traps and snare-traps are made to catch foxes and other small animals. The boys practice themselves in the use of the bow by shooting at marmots and small birds, and in winter they set horse-hair snares for snow-buntings. The majority of their modes of capturing and killing the lower animals have been so extensively described by other observers * that I will make no further reference to them here. But I will give an account of their eagle-hunt, which, as far as I know, has never been fully described in any book of travels, although Maximilian and Hayden both speak of it.

Eagle-hunting.-Late in the autumn or early in the winter, when they go out on their winter-hunt, a few families seek some quiet spot in the timber, and make a camp with a view to catching eagles. After pitching their tents, they first build a small medicine-lodge, where the ceremonies, supposed to be indispensable, are performed, and then make several traps on high places among the neighboring hills. Each trap consists of a hole dug in the earth, and covered with sticks, sods, etc.; a small opening is left in the covering; a dead rabbit, gronse, or other animal is tied on top; and an Indian is secreted in the excavation below. The eagle, seeing the bait, sweeps down and fastens his claws in it; but, the bait being secured, he is unable to remove it. When the eagle's claws are stuck, the Indian puts his hand out through the opening, and, catching the bird by both legs, draws him into the hole and ties him firmly. The trapper then re-arranges the top of his trap, and waits for another eagle. In this way many eagles are caught; they are then brought alive into camp, the tails are plucked out, and the bird is set at liberty, to suffer, perhaps, a similar imprisonment and mutilation at some future time.

The covered hole or trap is called amasi'. When the trapping-season is over, they break up the camp; and, if the locality is not already provided with a name, they call it the

* Particularly the exciting "buffalo-surround". Seo Catlin, N A. Indiaus, vol. I, p. 199 et seq.-Buller, p. 224 et seq. 
amasì' of whoever was master of ceremonies during the season. Two instances of this manner of naming are given in the list of Local Names.

The medicine-lodge is built after the manner of their ordinary earth-covered dwelling-houses, but is much smaller. The door-way is low and small; and the door, consisting of a skin stretched on a frame, is suspended from the top by a string. On the inside of the lodge, opposite to the door, is a sort of altar, on which various charms and relies are placed; around the edge, to the right and left of the door, hay is spread to serve as seats; and, in the center, is the fire-place. At night, after the trappers return, they sit to the left; their visitors sit to the right, as they enter. 'The latter enter and leave the lodge only by opening the door on the side corresponding with their seats. No person is allowed to spit on the floor, but he may spit behind him in the hay. Women are not allowed to enter the lodge, but may come to the door and hand in food and water.

When some of the men wish to take part in the trapping, they go, during the day, after a preliminary fast, to the medicine-lodge. There they contimue without food until about midnight, when they partake of a little nourishment, and go to sleep. They arise just before dawn, or when the morningstar rises; go to their traps; sit there all day without food or drink, watehing for their prey, and return about sunset. As they approach the camp, every one there rushes into his lodge, for the hunter must see, or be seen by, none but his fellowhunters until he enters the medicine-lodge. On entering the lodge, they stay there for the night. About midnight they eat and drink for the first time since the previous midnight, and then lie down to sleep, to arise again before the dawn and go to their traps. If there be one among them who has caught nothing during the day, he must not sleep at night, but must spend his time in loud lamentation and in prayer. The routine described must be continued by each hunter four days and four nights, after which he returns to his own lodge hungry, thirsty, and tired, and follows his ordinary pursuits until he feels able to go again to the eagle-traps. During the four 
days of the trapping, the hunter sees none of his family, and speaks to none of his friends except those who are engaged in the trapping at the same time. They believe that, if any eagle-hunter does not properly perform all these rites, the eagle, when caught, will get one of his claws loose and tear the captor's hands. There are men in the tribe who have had their hands crippled for life in this way.

The chief objects of pursuit in this hunt are the tailfeathers and largest wing-feathers of the war-eagle, Aquila chrysatus, which are in such great requisition as emblems of valor. Of course, other birds of prey besides the war-eagle often seize the bait; of such three species are considered worthy of capture; but these inferior birds are often slain at the trap instead of being brought home alive.

\$.28. Warfari. - The tales which some of the old men of this tribe tell of the warlike expeditions of their fathers and grandfathers seem scarcely credible, although from the descriptions of distant countries that they contain they bear internal evidence of truth. The journeys performed by the Hidatsa war-parties of the last century were very long, but those undertaken by single individuals were more extraordinary. I have heard it related (with many descriptive embellishments and minute particulars) of an old warrior that he traveled directly to the south on foot until he reached the Platte River; there he built himself a bull-boat, and floated far down the Lower Missouri, where he found the land all forest, and where he plucked fruits and shot birds such as he had never seen before; and there, from the head of some unknown Indian, he raised a scalp, and returned to his people after an absence of twenty lunar months. Another story is told of one who traveled toward the north-star until he came to a land where the summer was but three moons long. Here he raised the scalp of some poor Tinneh, and came back to his native village in about seventeen moons from the day he started.

The. Minnetarees now rarely meet the Shoshonees, or Snake Indians of the Rocky Mountains, either in war or in peace; yet, in 1804, as appears from the account of Lewis 
and Clarke, an almost constant warfare was carried on between these two tribes. There are old men now among the Hidatsa who speak of battles that they fought in their youth on the banks of streams that flow to the west. There are middle-aged men in this tribe who have, on mounted warparties, passed through the Dakota hunting-grounds to strike the Chippeways in Minnesota. When the Chippeways would see the tracks of the scalp-hunters pointing toward the western prairies, they would perhaps blame the Dakotas, and revenge themselves on the latter. Of late years, their military operations have become more restricted since the Dakotas have given them all they could attend to near home.

Occasionally they have pitched battles with their enemies, but most of their hostilities consist in the raids of small war-parties, whose great object is not to take many scalps at any hazard but to inflict some injury without loss to themselves. The popularity of a partisan leader depends much on the small eause for mourning which his excursions entail on the tribe. When, however, they fight to resist a war-party, or meet an enemy by accident when they are not out on a regular war-excursion, they fight with little regard for life.* Many of their war-parties start out on foot, expecting to return with stolen horses.

Prisoners of war----Young children are often taken prisoners of war. They are neither ill-treated nor compelled to perform unusual lạbors. Sometimes they are adopted by people who have lost children, and are then treated with parental kindness. When they have grown to maturity, they sometimes return to the tribe whence they came, but more often remain with their captors. I have never seen or heard of these Indians taking adult prisoners, for the purpose of torturing them to death, as was so common among the eastern tribes. The Hidatsa kills his enemy outright.

The bodies of the slain, however, they mutilate in every conceivable shape. Sometimes they burn them whole, on large pyres; sometimes they hack them in pieces and burn

* See account of a battle near Fort Berthold between Minnetarees and Sious, given by Boller, p. 145. 
the fragments as offerings to the sun. Palliser gives an account of a fight between the Minnetarees and the Sioux at Fort Berthold, which he closes with the following remarks:"The skirmish now terminated; the Sioux retired and the Minnetarees returned to their village in triumph, dragging the body of their unfortunate victim along with them. Then commenced a truly disgusting sight; the boys shot arrows into the carcass of their fallen enemy, while the women, with their knives, cut out pieces of the flesh, which they broiled and ate. I turned away chilled with horror, and the whole scene haunted me for hours, and frequently afterward."* I first read this after I had known these Indians for some years, and was much surprised, for I had nerer heard of cannibalism among them, and had known of cases where some had died of hunger without resorting to this practice, which, among starving Europeans, is not uncommon. I had also heard Mr. Palliser's former hunting-companions and acquaintances on the Upper Missouri speak of him in terms of high praise as a man of veracity; and I have heard the adventures related in his book corroborated by eye-witnesses; therefore I took particular pains to inform myself on this point; and I was assured by the oldest white residents, as well as by the oldest Indians, that none of this tribe had ever, under any circumstances, devoured human flesh. . They say that the neighboring tribe of Crees do sometimes eat parts of the bodies of enemies slain in battle; and they account for his assertion either by supposing that there were Crees visiting the camp at the time, or that the horrified Palliser " turned away chilled" upon witnessing the cutting and broiling, and without waiting tomsee if the flesh was eaten, but taking the latter for granted.

$\S 29$. STories.-Long winter-evenings are often passed in reciting and listening to stories of various kinds. Some of these are simply the accounts given by the men of their own deeds of valor, their hunts and journeys; some are narrations of the wonderful adventures of departed heroes ; while many are fictions, full of impossible incident, of witcheraft and magic. The latter class of stories are very numerous. Some of them 
have been handed down through many generations; some are of recent origin, while a few are borrowed from other tribes. Of course, the interest of a tale depends much on the way it is told; although the plot remains the same with different narrators, the accessories and embellishments are added by each one to suit himself. Thus, some old men acquire great reputations as story-tellers, and are invited to houses and feasted by those who are desirous of listening to them. Good storytellers often originate tales, and do not disclaim the authorship. When people of different tribes meet, they often exchange tales with one another.

As an example of their tales of fiction, I have selected a story, said to belong originally to this tribe, and to havè been known to it from time inmemorial. An old Indian will occupy several hours in telling it, with much elegant and minute description, which I omit. On the other hand, I add nothing, and give the following as a simple abridgment of the tale as I have heard it told.

Tale of fiction.-Near the mouth of Burnt Creek, on the east bank of the Missouri, are the vestiges of some large round lodges, which stood there before the Indians came into the land. They were inhabited by various mysterious beings of great power in sorcery. In one of the lodges lived the two great demi-gods Long 'Tail and Spotted Body; a woman lived with them, who took care of their lodge, and who was their wife and sister; and these three were at first the only beings of their kind in the world. In a neighboring lodge lived an evil monster named Big Mouth, "who had a great mouth and no head". He hated the members of Long 'Tail's lodge, and when he discovered that the woman was about to become a mother he determined to attempt the destruction of her offspring.

When Long Tail and Spotted Body were absent on a hunt one day, Big Mouth entered their lodge, and, addressing the woman, said that he was hungry. The woman was greatly frightened, but did not wish to deny him her hospitality; so she proceeded to broil him some meat on the coals. When the meat was cooked, she offered it to him in a wooden dish 
He told her that, from the way his mouth was made, he could not eat out of a dish, and that the only way she could serve him the food so that he could eat it was by lying down and placing it on her side. She did as he intimated, when he immediately devoured the meat, and in doing so tore her in pieces. She died, or seemed to die; but the children thus rudely brought into the world were immortal. One of these he seized, and throwing him into the bottom of the lodge, said: "Stay there forever among the rubbish and let your name be Atìtish."* The other he took out and threw into a neighboring spring, saying to him: "Your name is Máhash ; $†$ stay there forever, where you will love the mud and learn to eat nothing but the worms and reptiles of the spring."

When Long 'Tail and Spotted Body came home, they were horrified to find their sister slaughtered; they mourned her duly, and then placed her body on a scaffold, as these Indians do. After the funeral, they returned hungry to the lodge, and put some meat on the fire to cook. As the pleasant odor of the cooking arose, they heard an infantile voice crying and calling for food. They sought and listened, and sought again, until they at length found Atutish, whom they dragged forth into the light, and knew to be the child which they supposed was devoured or lost forever. Long Tail then placed Atutish on the ground, and, holding his hand some distance above the child's head, made a wish that "he would grow so high"; and instantly the child attained the stature, mind, and knowledge of a boy about eight years old. Then Long Tail made many inquiries concerning what had happened to him and the whereabouts of his brother; but the child could give no information of what took place during the visit of Big Mouth.

In a day or two after this transaction, the elders made for the child a little stick and wheel (such as Indian children use in the game called by the Candians of the Upper Missouri roulette), and bade him play round in the neighborhood of the lodge, while they went out to hunt again. While he was play-

* Or atutis. See 'atuti' in Dictionary.

tOr mahas. See 'maha' in Dictionary.

I have given abore these two names in an English form for the convenience of the reader. 
ing near the spring, he heard a voice calling to him and saying "miakas" (my elder brothier). He looked in the direction from which the voice proceeded, and saw little Mahash looking out of the spring. Wanting a playmate, Atutish invited him to come out and play. So Mahash came out, and the two brothers began to amuse themselves. But when Long Tail and his brother approached the lodge, on their return from the hunt, Mahash smelled them far off, rushed away like a frightened beast, and hid himself in the spring. When the elders returned, Atutish told them all that had happened while they were gone. 'They concluded that he of the spring must be their lost child, and devised a plan to rescue him, which they communicated to Atutish.

Next morning they made another and smaller roulettestick, for the enchanted child to play with. 'Then they divested themselves of their odor as much as possible, and hid themselves near the spring and to the leeward of it. When all was ready, Atutish went to the edge of the spring, and cried aloud "Mahash! Do you want to come out?" Soon the latter lifted his head cautiously out of the spring, raised his upper lip, showing his long white fings, snuffed the air keenly, looked wildly around him, and drew back again into the water. Atutish then went near where he had seen his brother rise, and called again to him; but the child answered from the water that he feared to come out, as he thought he smelt the hunters. "Have no fear," said Atutish; "the old men are gone out hunting and will not be back till night. I am here alone. Come out to the warm sunlight. We will have a good time playing; and I will give you something nice to eat." Thus coaxed and reassured, the other ventured out, still looking mistrustfully around him. Atutish then gave him a piece of boiled buffalotongue to eat, which the little boy said was the best thing he had ever tasted. "Very well," said Atutish, "let us play, and I will stake the rest of this tongue against some of your frogs and slugs on the game." Mahash agreed; and soon, in the excitement of the play, he forgot his fears. They played along with the roulette some time without much advantage on either side, until, at length, they threw their sticks so evenly 
that it was impossible to tell which was farthest from the wheel. 'They disputed warmly, until Atutish said, "Stoop down and look close and you will see that I have made the best throw." The other stooped over to observe; and, while his attention was thus engaged, his brother came behind the little fellow, seized him, and held him fast. Atutish then called to the concealed hunters, who ran up, threw a lariat around the struggling captive and bound him firmly. Having secured the wild boy, their next task was to break the spell by which his tastes and habits were made so unnatural. To accomplish this, Long Tail and Spotted Body put him in the sweat-house and there steamed him until he was almost exhausted. They then took him out and began to whip him severely. As they plied the lash, they made wishes, that the keen scent would leave his nose, that the taste for reptiles would leave his mouth, that the fear of his own kind would leave his heart, etc. As they progressed with this performance, he suddenly cried out to Atutish, "Brother, I remember myself now. I know who I am." When he said this he was released; and his first impulse was to run to the spring. He ran there; but when he reached the edge, he stopped, for he found that he no longer loved the black mud and the slimy water; and he returned to the lodge.

Long Tail then placed the twins side by side, and holding his extended hand, palm downward, above their heads, a little farther from the ground than on the previous occasion, wished that they would both be "so high"; when, at once, they grew to the size of boys about fourteen years old, and they grew in wisdom correspondingly. Then Long Tail made bows and hunting-arrows for the boys, and a pair of medicine-arrows for their protection and for use on extraordinary occasions; and he addressed them saying, "You are now big enough to protect yourselves. Go out on the prairie and hunt, and we will see which one of you will be the best hunter." After that time they went out every day, and became expert hunters.

Once, as they were looking for game among the hills, they came to a scaffold on which a corpse was laid. "There," said Atutish, "is the body of our mother. She was murdered, no one knows how." "Let us try the strength of our medicine- 
arrows on her," said Mahash; "perhaps we can bring her back to life." So saying he stepped close to the scaffold and shot straight up. As the arrow turned to fall, he cried out, "Take care, mother, or you will get hurt;" and, as it descended near the body, the scaffold shook and a low groan was heard. Then Atutish stepped nearly under the scaffold and shot up in the air. As his arrow turned to fall, he cried out, "Mother! Mother! Jump quick, or the arrow will strike you." At once she arose, jumped down from the scaffold, and, recognizing her children, embraced them. T'the boys then asked her who was the author of their calamities, and how it all happened. She pointed to the lodge of Big Mouth, and related all the circumstances of her death. Upon hearing this, the boys swore they would be revenged. Their mother endeavored to dissuade them, describing Big Mouth to them, assuring them that his medicine was potent, and that he would certainly destroy them if they went near him. They paid no attention to her remonstrances, but proceeded to plot the destruction of the monster.

Now, this Big Mouth had a very easy way of making a living. He neither trapped nor hunted, nor took pains to cook his food. He simply lay on his back, and when a herd of deer eame within sight from his lodge, or a flock of birds flew overhead, no matter how far distant, he turned toward them, opened his great mouth, and drew in a big breath, when instantly they fell into his mouth and were swallowed. In a little while, the boys had their plans arranged. They built a large fire, and heated some small bowlders in it. Then they carried the stones to the top of his lodge, put them near the smoke-hole, and began to imitate a flock of blackbirds. "Go away, little birds," said Big Mouth; "you are not fit to eat, and I am not hungry; but go away and let me sleep, or I will swallow you." "We are not afraid of you," said the boys; and they began to chirp again. At length Big Mouth got angry. He turned up his mouth, opened it wide, and just as he began to draw his breath to suck them in, the boys stepped aside, and hurled the stones down into the lodge. "Oh, what sharp claws those birds have! They are tearing my throat," exclaimed the monster, as he swallowed the red-hot rocks. The next moment he 
roared with pain and rushed for his water-jars, drinking immense draughts; but the steam made by the water on the rocks swelled him up; and the more he drank the worse he swelled until he burst and died.

The boys brought the body home, and, after they had danced sufficiently around it, their mother praised them for what they had done, but she said, "You must not be too venturesome. All these lodges around are inhabited by beings whose powers in sorcery are great. You cannot always do as well as you have done this time. You should keep away from the rest of them. 'There is one old woman in particular whom you must avoid. She is as powerful as Big Mouth; but you cannot kill her in the same way that you killed him, for she catches her food, not in her.mouth, but in a basket. Whenever she sees anything that she wants to eat she turns her basket toward it and it drops in dead. If she sees a flock of wild geese among the clouds, no matter how high they fly, she can bring them down." When the boys heard this, they said nothing in reply to their mother, but set off secretly to compass the death of the witch. They went to the lodge of the latter, and, standing near the door, cried, "Grandmother, we have come to see you." "Go away, children, and don't annoy me," she replied. "Grandmother, you are very nice and good, and we like you. Won't you let us in?" continued the boys. "Oh, no," said she, "I don't want to hurt you ; but begone, or I will kill you." Despite this threat, they remained, and again spoke to her, saying, "Grandmother, we have heard that you are very strong medicine, and that you have a wonderful basket that can kill anything. We can scarcely believe this. Won't you lend us the basket a little while until we sce if we can catch some birds with it?" She refused the basket at first, but, after much coaxing and flattering, she landed it to them. No sooner were they in possession of the basket than they turned it upon the witch herself, and she dropped into it dead.

After this exploit, the mother again praised her boys, but again warned them to beware of other evil genii of the place, which she described. One of these was a man with a pair of 
wonderful moccasins, with which he had only to walk round anything that he wanted to kill. Another was a man with a magic knife, with which he could instantly cut or kill anything that he threw the knife at. These individuals they destroyed in the same manner that they overcame the basket-woman, by coaxing them to lend their magic property, and then slaying the owners with their own weapons. On each occasion, the boys retained the charmed articles for their future use.

When all this was done, the old mother called her boys and told them there was but one more dangerous being that they had to guard themselves against. She said, "He lives in the sky, where you can not get at him; but he can hurt you, for his arm is so long that it reaches from the heavens to the earth. His name is Long Arm." "Very well," said the boys, "we will beware of him." One morning, soon after receiving. this advice, they went out very early to hunt, but could find nothing to kill. 'They walked and ran many miles, until late in the day, when they became rery tired and lay down to sleep on the prairie. As was their custom, they stuck their medicine-arrows in the gromd, close beside them. The arrows possessed such a charm that if any danger threatened the boys they would fall to waken them. While the brothers lay asleep, Long Arm.looked down firom the clouds, and, beholding them, stretched his great arm down toward them. As the arm descended, the arrows fell hard upon the boys, but the latter were so tired and sleepy that they did not waken, and Long Arm grasped Atutish and bore him to the sky. In a little while, Mahash woke up and discovered, to his horror, that the warning arrows had fallen and that his brother was gone. He looked round carefully on the prairie for the departing tracks of his brother or for the tracks of the man or beast that had captured him, but in vain. When at his wit's end, and almost in despair, he chanced to glance toward the sky, and there, on . the face of a high, white summer cloud, he saw the doubled track of Long Arm, where he came near the earth and went back. Mahash laid down his bow and arrow and other accouterments, retaining only his medicine-knife, which he concealed in his shirt. He next stuck his magic arrows into the 
ground and got on top of them, and then he crouched low, styained every muscle, and sprung upward with all his might. He jumped high enough to catch lold of the ragged edge of the cloud. From that he scrambled higher until he at last got on Long Arm's trail, which he followed. For fear of recognition, he wished himself smaller, and, becoming a little, toddling child, moved on until he came to a great crowd, moving in one direction, with much talk and excitement. He ran up to an old woman who walked a little apart, and asked her what was the matter. She informed him that they had just captured one of the children of the new race which was growing on the earth-a boy who.had destroyed many favored genii, and that they were about to kill and burn him. "Grandmother," said Mahash, "I would like to see this, but I am too little to walk there. Will you carry me?" She took him on her back and brought him to the place where the crowd had gathered. There he saw his brother' tied to a stake, and a number of people dancing around him. He thought that if he could only reach the post unobserved and touch the cords with his medicine-knife, he could release his brother; but for some time he was puzzled how to do it. At length he slid down from the old woman's back, and wished that for a little while he might turn to an ant. He became one, and, as such, crawled through the feet of the crowd and up to the post, where he cut the cords that bound Atutish. When the latter was free, Mahasi resumed his proper shape, and they both ran as hard as they could for the edge of the clouds. The crowd pursued them; but, as each foremost runner approached, Mahash threw his knife and disabled him. At last, Long Arm started after the brothers, rumning rery fast. As he came within his arm's length of them, he reached out to grasp one of them. As he did so, Mahash again threw his knife, and severed the great arn from the shoulder. The boys got back safely to the earth. Then, having ridded themselves of all their enemies, they lived in peace, and in time they moved away from that locality.

\$30. Divisions of Time.-Many writers represent that savage Indian tribes divide the year into twelve periods corre- 
sponding to our months, and that each month is named from some meteorological occurrence or phase of organic creation observable at the time. Among others, Maximilian presents us with a list of twelve months, *_"The month of the seven cold days", "The pairing month", "The month of weak eyes", etc. He introduces this list in one of his chapters descriptive of the Mandans. He does not say it is their list of months. He publishes it without comment; and yet it is presented in such a way as to lead the reader to suppose that it is the regular and original Mandan calendar. Other authors present lists of Indian months in much the same way. As the results of my own observations, I should say that the Mandans and Minnetarees are generally aware that there are more than twelve lunations in a year, that they as yet know nothing of our manner of dividing the year, and that, although when speaking of "moons", they often connect them with natural phenomena, they have no formal names for the lunar periods. I think the same might be said of other tribes who are equally wild.

The Hidatsa recognize the lapse of time by days, by lumar periods, and by years. They also recognize it by the regular recurrence of various natural phenomena, such as the first formation of ice in the fall, the breaking up of the Missouri in the spring, the melting of the snow-drifts, the coming of the wild geese from the south, the ripening of various firuits, etc. A common way of noting time, a few years ago, was by the development of the buffalo calf in utero. A period thus marked by a natural occurrence, be it long or short, is called. by them the kadu, season, time, of such an occurrence. Some long seasons include shorter seasons; thus they speak of the season of strawberries, the season of service-beries, etc., as occurring within the season of warm weather. They speak of the seasons of cold weather, or of snow (tsidie, mada), of warm weather (ade), and of death, or decay (mata), which we consider as agreeing with our seasons of winter, summer, and fall ; but they do not regularly allot a certain number of moons to each of these seasons. Should you ask an interpreter who knew the European calendar what the "Indian names of the 
months" were, he would probably give you names of a dozen * of these periods, or natural seasons, as we might call them, corresponding in time to our months. In a few years, when these Indians shall know more of our system of noting time than they now do, they will devise and adopt regular Hidatsa names for the months of our calendar.

Other facts concerning their cognizance of time may be learned from Paragraphs 256 and 257 of the Grammar, and by referring in the Dictionary to the following words, which are names of different parts of the astronomical day:-atade, ata, kiduhakute, midiatede, midiate, midiatedu, midiate-odaks̈ipe, midimapedupahide, midimapedupahi, midimapedupahi-dakamidi, midiimahpide, midiimalipi, opade, opa, oktside oktsi, oktsidu, mape and maku. 
PHILOLOGY. 



\section{P H I L 0 L 0 G Y.}

\$I. Classification of the Hidatsa language.-The language of the Minnetarees has been classified as belonging to the linguistic group called the Dakota group, and very properly so called, not because there is any evidence that the present Dakota tongue is the parent language of the group or the most direct representative of an archaic parent language, but because it is the most extensively spoken, and the most thoroughly and intelligently studied language of the group.

\$II. Relations of Dakota to Hidatsa.-The Hidatsa language resembles the Dakota in many respects; and a large list might be made of words which are the same in both languages, if we allow for the interchangeability of certain lingual and labial sounds in the Hidatsa, to be described hereafter. The following are examples:-hota, gray; i, mouth; ista, eye ; itopa, fourth; una, $I$; mini or midi, water; nita or dita, thine; nopa or dopa, two; te, die; topa, four; besides particles, such as i, denoting the instrument, to, interrogative, etc.

There are many more words in each language which very closely resemble their synonymes, or approximate synonymes, in the other; and several which in both languages are perfect homonymes and imperfect synonymes. These statements are illustrated in the following list:-

(DAKOTA.*)

dote,

hi,

hil),

ha,

inkpa,

inonpid,

ité,

mita,

nitawa,
(HIDATSA.)

doti, throat;

hi, tooth, edge, point;

hi', feuthers, fur, hair ;

ha, rough;

icpu, point;

inopa, second;

ite, face ;

mata, my, mine;

matawae, mine;

" The Dakota words used throughout this essay are from Rev. S. R. Riggs's Dakota Grammar and Dictionary. Where the Dakota definitions differ from the Hidatsa, they are given separately. 


\section{(DAKOTA.)}

nagi $i$,

ग, to shoot and hit, oti, ti, tipi,

ożu,

po,

pte,

pute,

supe,

to,

u,

wa,

wasićun,

wata,

win,
(HIDATSA.)

dahi or nahi, ghost;

$\mathrm{u}$, to wound;

ati, house ;

oze, to plant;

pue, foggy ;

mité, cow;

apute, upper lip ;

sipe, bowels ;

tohi, blue ;

hu, to come;

ma' or wa', snow ;

masii or wasii, white man;

mati or wati, boat;

mia or wia, woman.

In a number of words which are nearly or quite synonymous in both languages, we find little difference in sound, except that the Dakota é (English ch in chain) stands in place of the Hidatsa $d$; as in these examples :-

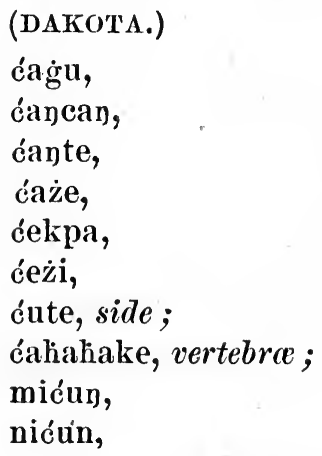

(HIDAT'SA.)

daho, lungs ;

dada, to tremble;

da'ta, heart;

dazi, name ;

dehpa, navel ;

dezi, tongue;

duta, ribs ;

dalialia, vertebral processes ;

madu, my elder sister;

didu, or nidú, thy elder sister.

More commonly, however, we find the difference to consist chiefly in the Dakota words having y, where the Hidatsa words have d. As the Dakota causative prefixes ya and yu are represented in the Hidatsa by da and du, many verbs may be placed under this head. In the following words, and in many others, we have instances of this difference :-

(DАКота.)

ya,

ya, to go,

yagia, to peel with the teeth, yahdeca, to tear with the mouth, yahepa, to drink up, as water, yamni,
(HIDATSA.)

da, thou;

da, go thou ;

dahade, to shell with the teeth;

dahesa, to tear with the teeth;

daliupi, to drink dry;

dami, three; 
(DAKOTA.)

yuha, to lift,

yubleća, to tear in pieces, ete.,

vulipa, to throw down, etc.,

yuhuga, to breuk a hole in, etc.,

juksa, to break off, etc.,

yuska, to loosen, to untie,

yuskića, to press, squeeze,

yuti,

yuza,
(IIDATSA.)

duhe, to lift, duha, lift thou ;

duhexa, to tear in any vay ;

duhpi, to take down off of ;

duhohi, to break across ;

dutsaki, to pull apart;

dusika, to open, as a box;

dutsikti, to strangle;

duti, to eat;

dutsi, take hold of.

In some of the above verbs it will be seen that the roots are much alike in both languages. Many of the quoted definitions embody similar ideas, although they are differently worded. It is well to remind the reader that even in the Dakota, in verbs begimning with ya and yu, the $y$ is changed to $d$ in the conjugation. (See Rigos's Dakota Grammar, §50.)

In sone cases, we find that the Dakotas use s where the Hidatsa usually use ts; but on this point usage is somewhat divided in the Hidatsa. (See Grammar, I 17.)

(1)AKOTA.)

liaska,

sibe,

sinte,

sni,

nisunka,
(HIDA'TSA.)

liatski,

tsi (itsi),

tsite,

tsiclia,

ditsuka, nitsuka,
(ENGLISH.)

- long ;

foot;

tail ;

cold ;

your younger brother.

And some other words might be quoted to exemplify this difference.

In the words naggi and dahi, cağn and dalio, yaga and daliada, quoted above, and in others, the go dakota takes the place of hin Hidatsa.

Although, as has been shown, there are many words alike or nearly alike in these two languages, allowance being made for certain uniform sound-changes, it must be remembered that a large majority of the Dakota words have no resemblance to anything in the Hidatsa. Reduplication in verbs, which is a prominent feature of the Dakota tongue, I have not observed to occur in the Hidatsa except in one word, ikaka.

\$ III. Relations of Crow to Hidatsa.-The Hidatsa bears a greater resemblance to the Crow than to any other language. Some speak of one as being but a dialect of the 
other; and so they might be regarded if we use the word dialect in a very wide sense. The Crow has its own dialects, differing to no great extent from one another. My opportunities for studying this language, particularly the dialects of the Mountain Crows, have been very limited. A vocabulary which I prepared of the language as spoken by the River Crows has been destroyed. I cannot, therefore, give a very full comparison of the Crow and Hidatsa. The Crow words presented below are from Dr. Hayden's Ethnography and Pliilology, which contains the most complete and accurate Crow vocabulary extant.

A comparison of Hayden's Crow vocabulary with this Dictionary shows that many words of similar meaning are spelled alike in both, as adaka, you see; amaka, I see; apaka, a mosquito; da, go; di, you; ika, he sees; maha, a spring; mape, day ; ope, tobacco ; na, a wife, etc.; and that many other synonyms are nearly alike in spelling, as in the following examples, in each of which the Crow word precedes the Hidatsa:ame, ama, earth ; apahe, apahi, cloud ; ape, apa, leaf; aze, azi, river ; daho, daho, lungs ; dahpitse, dahpitsi, bear ; deze, dezi, tongue ; due, duhi, lift ; ho, hu, come ; hoće, hutsi, wind; ide, idi, blood; mia, mi', stone ; mie, mia, woman; mihahe, mihaka, duck; oki, uki, clay; poh̀, puhi, foam.

The oft-quoted consonants (Grammar, II 19-23), which are interchangeable in the Hidatsa, are also interchangeable in the Crow, but perhaps in a less degree in the latter than in the former. Of the labial series, the Crows seem to prefer $b$ more than the Hidatsa; and of the linguodental series they use $r$ and $n$ to a greater extent than we find it used by the latter tribe. By taking this permutation of consonants into consideration, we find many words alike or nearly alike, both in Crow and Hidatsa, which would otherwise seem different. Examples :-

(CROW.)

ainahabe,

are,

are, arek,

apani,

apani,
(HIDA'T'SA.)

amahami,

ade,

ade, adets,

apadi,

apadi,
(ENGLISH.)

mountain ;

icarm;

ache, it aches:

to grow:

porcupine ; 


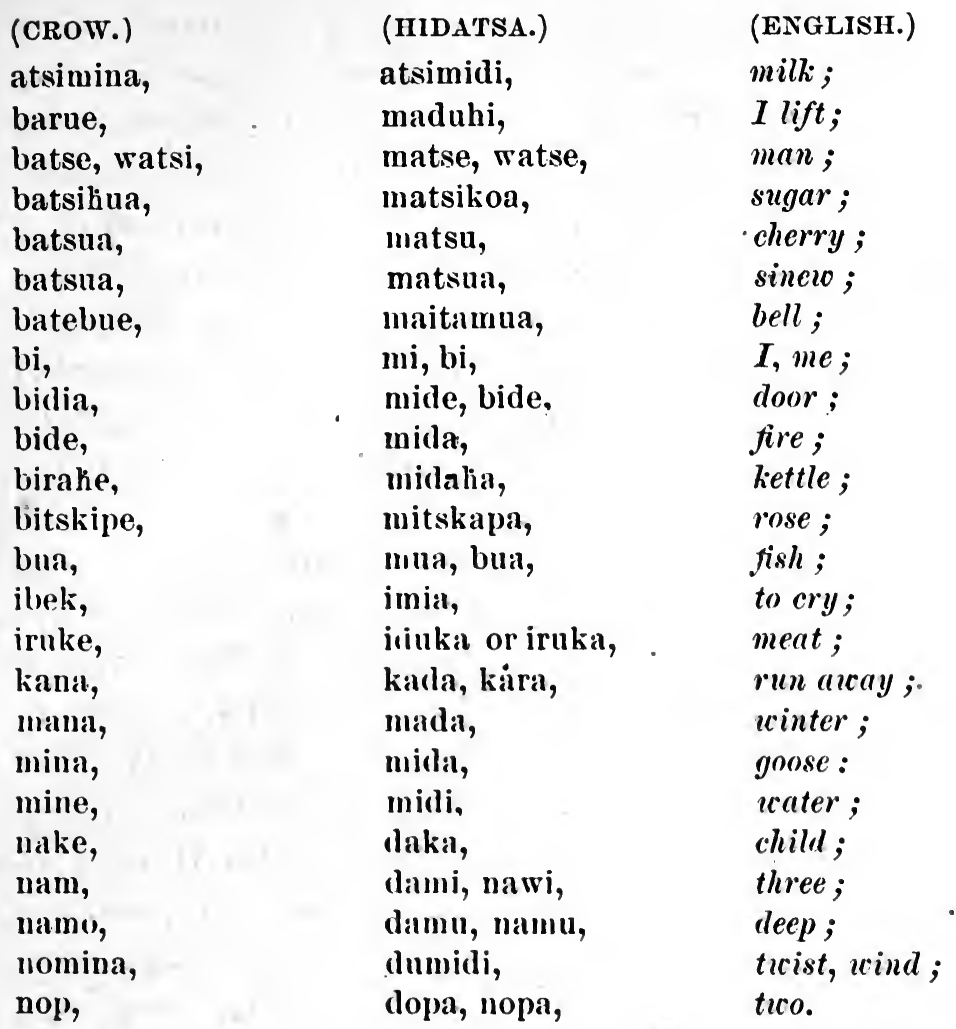

The Crows commonly use a sibilant, as $s$, sh, or: $z$, where the Hidatsa use some other dental, as $t$. 'There are many Crow words which, except in this respect, differ but slightly or not at all from their Hidatsa synonymes, as the subjoined list will show:(CRow.)

ashe, ashu, bas, bise, basape, baze, bishe, dusa, isa, ise, same, sapa, sape, sheëk, shipie,
(HIDA'TSA.)

ati,

ati,

máta, matá, matapa, mati, mite, bite, duta, ictia, ite, 1ami, tuami, tapa, tape, tets, tipia,
(ENGLISH.)

house;

head ;

mine;

autumn;

my moccasin;

boat :

buffalo ;

rib;

large;

face;

how many;

what;

vho;

dead;

mud; 
(CROW.)

sho, shorak, shop,
(HIDA'TSA.)

to,

todu, topa,
(HNGLISH.)

where;

where, etc.;

four.

In a few cases, the above rule seems to be reversed, as in buata, motsa, coyote, wolf; dakaka, tsakaka, bird; tamel, tsame, hot; azkate, azikaza, little river; miekate, miakaza, young woman; tseete, tsesia, wolf; atanua; asiadi, to stecl. In these examples, the Crow words stand first.

The Crow has an oral period as well as the Hidatsa; in the former it is $\mathrm{k}$, in the latter ts. (See Grammar, II 33,168 .) As these oral periods are much used, they constitute an important element in the difference in tone of the two languages.

The Crows sometimes use $\mathrm{s}$ where the Hidatsa use $\dot{\mathrm{s}}$ or ts, and $\dot{c}$ (English $c h$ in chain) where the Hidatsa use k. There are many other instances of changes of sound in these languages which I have not now the means of illustrating sufficiently.

$\$$ IV. Some difficulties in the study of the Hidatsa.The interchangeable labial and linguo-dental sounds are very perplexing features of this language. The sounds of $m, b$, and $w$ are interchangeable; so also are those of $d, l, n$, and $r$. These permutations exist in other Indian tong!nes, though in few, I presume, to the extent to which they exist in this tongue. In the Dakota language, for instance, changes in these sounds are said to mark difference in dialect, while within each dialect the labials and linguals are not interchanged to an extent sufficient to excite remark.

The present Hidatsa tribe represents several bands formerly distinct; and the present. language of this people, no doubt, represents nearly as many ancient dialects, the distinctive features of which cannot easily be determined at this day. The consolidation of these diverse dialects has had, perhaps, some share in producing this confusion of sounds; but, at most, it has had a very limited share. I believe that these Indians do not well appreciate the differences between these allied sounds as they fall on their ears, and consequently make no effort to distinguish them with their tongues. I have often, 
for experiment, taken a word which contained two or more of these sounds, and pronounced it, in the course of conversation, with every possible change, and without being once misunderstood. Thus, the word madakoe, my friend, my comrade, which contains but one labial and one dental sound, may be pronounced in at least twelve different ways, - which we have characters to represent, as, madakoe, marakoe, manakoe, malakoe, badakoe, barakoe, banakoe, balakoe, wadakoe, warakoe, wanakoe, and walakoe,-without fear of misapprehension, although they usually pronounce it malakoe or barakoe. Furthermore, when you hear an Indian uttering a sound belonging to one of these two series, you are often at a loss to select a character to express it. His labial will often sound as much like $m$ as like $b$, or as much like $w$ as $m$. Among linguo-dental sounds, it is often impossible, even after several repetitions of a word by an Indian speaker, to decide between $d$ and $r$, or between $d, l$, and $n$, as the best suited to represent the sound that smites your ear. In other words, there are labial, lingual, and dental sounds which we have not yet learned to distinguish, and which we have no characters to represent. I marvel not that old Charbonneau should have "candidly confessed" to Prince Maximilian, after a residence of thirty-seven years among the Minnetarees, that he could never learn to pronounce their language correctly.*

In the Grammar (II 19-23), where this subject is further discussed, it will be seen that I have selected a standard letter to represent each series, $-m$ for the labial, and $d$ for the lingual or linguo-dental. When I first commenced to form my vocabulary, I adopted a different course, and put down each word in all the forms in which $I$ heard it; but, in time, I discovered that I might fill a large volume with these repeated words, and, in the end, only confuse the student, obscure the truth, and misrepresent the language.

When I first obtained some insight into the extent to which these permutations existed, I could scarcely trust my senses, and often feared that I labored under some subjective difficulties. At other times, when, in the mouth of the same speaker, and almost in the same breath, I would hear a well- 
known word suddenly change its form, I would puzzle myself by supposing that the change took place in accordance with some inscrutable grammatical rule. But when I came into the possession of vocabularies collected by others, I became better satisfied with the results of my own observations. In the compared vocabularies presented below, it will be seen how differently each author spells one and the same word, and that their differences arise chiefly from the transmutability of the sounds to which I have referred. In the first column (Say), the vowels have the English sound; and, in the second column (Hayden), they have the continental sound.

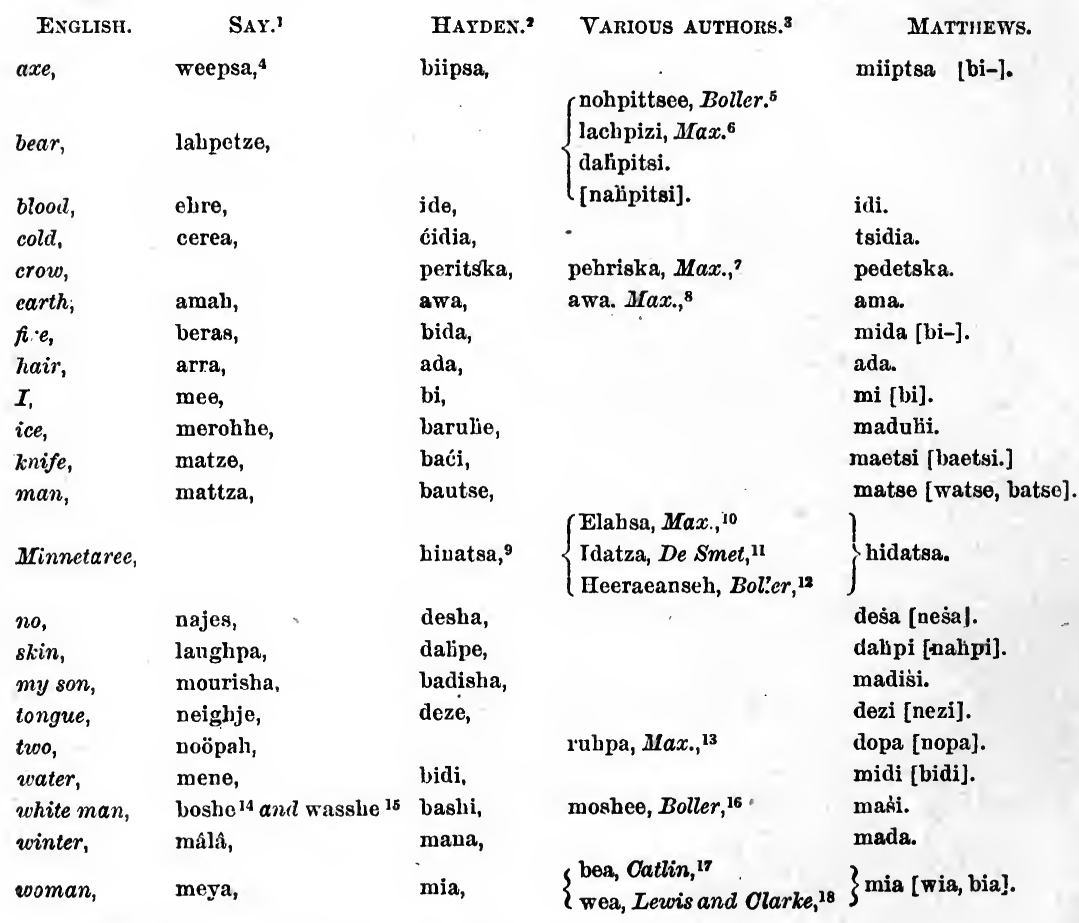

From Dr. Say's Vocabnlary in Long's Expedition, pp. 1xx-lxxviii and p.1xxxiv.

2 From Dr. Haylen's Minnetaree Vocabulary in Hayden's Ethnography and Philology, pp. $424-46$. 3 Taken from various parts of the works of the authors to whom referred.

4 "Tomahawk, weep-sa-lan-ga", p. Ixxxv ; (See miiptsa daka, in Dictionary.)

5 "Noc-pitts-ee-toapish, or Fonr-Bears." " Boller, p. 56.

6 "Lachizi-sihrish (the yellow bear)." Maximilian, p. 180. The letters hare here their German sounds probably.

7 "Pehriska-Ruhpa (the two ravens)." Max., p. 180.

8 The first two syllables of "A wachawi", p. 178. (See amahami in the Dictionary.)

9 "Indian, hinatsa."

${ }_{10}$ Max., p. 178. (See Ethnography, $§ 18$. Hidatsa.)

11 "The Idatzas, miscalled Grosventres." From letter in Report of the Oommissioner of Indian Affairs for 1864, p. 276 .

12 "Men of the Hee-rae-an-seh", p. 97.

13 "Pehriska-Ruhpa, (the two ravens)." See note 7 above.

14 "French, bo-she", p. Ixxxiv.

15 "Spaniard, was-she-0-man-ti-qúa", p. 1xxxiv. (See madi and umatikoa in Dictionary.)

16 "Leaving the 'moshees' (whites) to reflect", etc., p.187.

17 In the feminine ending of the name "Seetsebea", p. 188. (See Grammar, Tा 93.)

18 In the feminine ending of the name "Sacajawea", p. 279. 
Lest some should urge that these variations in orthography might be sufficiently accounted for by taking into consideration the changes which time may have produced in the language-for the quoted authors wrote at different dates-or by supposing the vocabularies to have been written from the dictation of men who spoke different dialects, I must call attention to the fact that there are many instances where one word, in different connections, is spelled with different interchangeable consonants by the same author. (In the following examples, the Hidatsa words in parentheses are forms given in the accompanying Dictionary.) Thus, Say presents us with two different forms of duetsa or luetsa, one, in "nowassa-pa" (duetsapi), nine, and "ape-lemoisso" (alipiduetsa), eleven; with two forms of daka, child, a diminutive ending, in "sacanga-nonga" (tsakaka-daka), egg, and "weepsa-langa" (miiptsa-daka), tomahark; ; with two forms of mas̈i, white man, in "French, boshe", and "Spaniard, wasshe-omantiqua" (the latter is doubtlessly intended for masi umatikoa, white men at the south-see note 15, page 82); and with two forms of dolipaka, people, in "Snake Indians, mabucsho-rochpanga" (mapoksa, dohipaka), and "Les Noire Indians, ateshupesha-lohpanga" (ati, sipisa, dohipaka). In Hayden's vocabulary, we find two different spellings of matse, man, in "bautse-itse" (matse-etsi), chief, and "makariste-matse" (makadista-matse), boy; two spellings of adui, sour, pungent, etc., in "adawi", sour, and bidi-arawi (midi-adui), whisky; and two spellings of midi, sun, in "midli-ewukpi" (midi-imahpi), sunset, and "bidi-waparepehe" (midi-mapedupahi or bidiwaperupahi), midday, noon. I regret that, in preparing these remarks, I have not had access to a copy of Maximilian's original work, which contains a vocabulary of the Minnetaree language; but I have no doubt that instances of this kind might be drawn from it.

Besides making the various labial interchanges mentioned above, they sometimes, but very rarly, use $b$ for $p$; and occasionally, too they combine the sounds of $b$ and $w$, thus ama may be pronounced abwa. A third series of interchangeable consonants might be mentioned, namely, a sibilant series. To some extent they confuse the sounds of s, $\dot{\mathrm{s}}$ (English sh in shun), 
and ts (see Grammar, II 17,18), and illustrations of this confusion might be taken from the vocabularies I have quoted; but these sibilant interchanges do not occur to such a marked extent as do the labial and lingual changes, and, when heard, they are not so perplexing to the English student.

$\S V$. Sonant character.-The Hidatsa language is sonorous and pleasing to the ear; but I consider it less musical than the Dakota. One of the chief reasons for the difference in tone between the Hidatsa and Dakota languages, I believe to be the almost total absence, in the former, of the nasal-vowel ending (n) so common in the latter (see Grammar, II 4, 14). The aspiration of the vowel in the Hidatsa takes the place of the nasal ending to a great extent. Another reason for difference of tone is that the Hidatsa shorten and obscure their vowels to a greater extent than the Dakotas. The Hidatsa is spoken with much inflection, and the vowels are often increased in quantity to express different shades of meaning.

If a party of Indians should be seated in an adjoining room, or at a short distance from the listener, conversing, where the voices can be heard, but not a syllable distinguished, the accustomed ear has little difficulty in discerning which one of - the many languages of the plains the Indians are speaking. Each language has its own peculiar sonant character. It is more difficult to distinguish by this character the Hidatsa from the Crow than from the Dakota or Mandan, and more difficult to distinguish it from the latter than from the former of these two. The tones of these four languages belonging to the Dakota group are somewhat alike; so much alike that a person possessing but limited acquaintance with them might mistake one for another, hearing it at a distance as I have described. But the contrast in tone between these tongues and the neighboring, but alien, Arickaree is well marked, and any quickeared person might learn at once to distinguish it from them.

§VI. Changes in course of Time.-I have said that the three languages spoken in the village at Fort Berthold show no perceptible inclination to coalesce (Ethnography, §13). I havie said this, well knowing that the statement was somewhat at 
variance with the opinions of earlier observers.* 'The few Mandan and Mimetaree words given by Lewis and Clarke in proper names show, as far as they go, that the languages have not materially changed since 1804 . There are now, and doubtlessly there were in 1804 , many points of correspondence between the Mandan and Hidatsa languages; but there are none which may not be more easily explained by supposing the two languages to have sprung from a common source than by supposing them to have been reciprocally changed by contact. I never could discover that the Hidatsa and Mandan spoken by the rising generation resembled one another more than did those languages as spoken by the old men. I do not claim that the long and intimate intereourse which has existed between these two tribes has produced no approximation or coalescence of their languages. It is but reasonable to suppose that the contrary is the case; but I could never get an Indian to point out to me, nor could I ever otherwise discover, a satisfactory instance of such coalescence.

Throughout the past hundred years, the Mandans have had as much intercourse with the Arickarees as with the Minnetarees; yet I never could trace any resemblance between the modern Mandan and Arickaree tongues. As far as I have observed them, there is not a single word alike in both. It is not likely that intercourse has produced a noteworthy approximation of languages in one case and none whatever in the other. There is no doubt that the Hidatsa language has changed in the course of time; but the change has resulted chiefly from causes other than the influence of the Mandan tongue. Some of the old men occasionally converse among themselves in terms which younger members of the tribe do not understand, and, when asked what they mean, they say they are trying to speak the old language.

\footnotetext{
* Lewis and Clarke, p. 97.-Maximilian, pp. 393, 405.
} 

HIDATSA GRAMMAR. 



\section{HIDATSA GRAMMAR.}

\section{LETTERS.}

1. Tirenty letters, exclusive of the apostrophe, are used in this work to express in writing the Fidatsa lauguage. Fifteen of the letters are essential, and five non-essential.

\section{Essential Letters.}

2. Of the essential letters, five are vowels, and ten, consonants.

3 . The rowels are $\mathbf{a}, \mathbf{e}, \mathbf{i}, \mathbf{o}, \mathbf{u}$.

a has three sounds; - a (unmarked) has the sound of English $a$ in father; $\breve{a}$ (short) has the sound of English $a$ in vhat; a (obscure) has the sound of short $\breve{u}$ in $t u n$.

e has three sounds; -2 (unmarked) has the sound of English $a i$ in air; $\breve{e}$ (short) has the sound of English $e$ in ten; $\bar{e}$ (long) has the English sound of $e$ in they.

$i$ bas two sounds; $-i$ (unmarked) has the sound of Euglish $i$ in marine; $r$ (short) has the sound of Euglish $i$ in tin.

- has, the sound of English $o$ in tone.

u has the sound of English $u$ in rude.

4. The apostrophe (') is placed after yowels to denote a peculiar force or aspiration, not initial, in pronouncing them, which slightly modifies the sound.

5. The consonants are $\mathbf{c}, \mathbf{l}, \mathbf{h}, \mathbf{h}, \mathbf{k}, \mathbf{m}, \mathbf{p}, \mathbf{s}, \dot{\mathbf{s}}, \mathbf{t}, \mathbf{z}$.

c has the sound of German ch in ich.

d bas the common English sound before consonants; but before rowels it has a slight sound of English th in this. d is interchangeable with $n, l$, and $r$.

h has the sound of English $h$ in hat.

li represents the guttural surd no longer in use in English; it is like the German ch in machen, but a somewhat deeper sound.

$k$ has the English sound, as in took.

m has the ordinary English sound, as in man; it is interchangeable with $b$ and $v$.

p has the ordinary English sound, as in pan.

$s$ has the sound of English $s$ in sun.

is has the sound of English sh in shun.

t has, before consonants, the ordinary English sound, as in tin; but before rowels it has a slight sound of English th in thin.

$z$ bas the sound of English $z$ in azure. 


\section{Non-essential Letters.}

6. The non-essential letters are five of the seren interchangeable consonants of the language; they are $b, l, n, r$, and $w$; they have all the ordinary English sounds. The language might be written or spoken without them. b and $\mathrm{w}$ are interchangeable with the essential letter $\mathrm{m}$, and $l, n$, and $r$ with the essential letter $d$.

\section{Remarlks.}

7. As no great advantage could be seen in retaining two sets of characters, capitals are, here, entirely dispensed with in writing the Indian words; but, in the Ethnography, where a Hidatsa proper name is used, temporarily, as an English word, the initial letter is a capital. Proper names are easily recognized by the termination s.

8. The following letters of the English, it will be seen, are not included in this alphabet: $f, g, j, q, v, x$, and $y$. The sounds of $f, g,{ }^{*}$ and $v$ are not in the language. It is a difficult matter for these Indians, or any one else, to pronounce $i$ followed by a vowel (and many other vowel combinations) without an intervening consonantal sound of $y$; elsewhere in their tongue this sound is not heard, and a character to represent it would be useless. ' $\mathrm{k}$ is the equivalent of $q$. English $j$ might be represented by dz, and $x$ by ks; but neither of these combinations has been found in the Hidatsa.

9. Some of the tribe occasionally pronounce the first sound of a like English $a$ in hall, and make other slight variations of the vowel sounds, which, however, seem to be only individual peculiarities of speech, or modifications unavoidably produced by preceding or succeeding consonants. It is believed that all the standard variations are duly represented.

10. Often before a final ts, and more rarely befure a final $\mathrm{k}$ or $\dot{\mathrm{s}}$, long rowels may be shortened, e changed to $\breve{1}$, and a to ạ. (शी 30-33).

11. It was originally thought advisable to include a short $\breve{u}$ in the alphabet, or to introduce a new character to represent the sound of English $u$ in $t u b$; but it is now believed that wherever this sound constantly occurs it is as a modification of a.

12. o is never shortened, as in the English word not; but a soand much like short $\breve{o}$ is heard in the modification of a, which is represented thus, $\breve{a}$.

13. The sounds of English $u$ in pure and oi in oil, are not found in this language; nor is the sound of ou in our ever used except occasionally in the word ho or hao.

14. The nasal modification of vowels, so common in the Dakota, does not properly belong to the Hidatsa, although a few of the tribe use it with aspirated a in the worls átsi, idáti, iba'taha, and liaka'ta.

* In the words lioki, iplioki, matslioki, and one or two others, I have occasionally heard the $\mathrm{k}$ softened into a hard $g$. 
15. The sound represented by c occurs only after i, and in accented syllables which are not terminal.

16. The English sound of ch in chain is represented by tis.

17. In words beginning with ts, the $t$ is occasionally dropped by women and young people, who thus say sạkits for tsạkits, sitska for tsitska, etc.; but, according to the best usage of the language, the plain sibilant is never found alonewith a vowel and nerer begins a syllable.

18. Sometimes ts is used where ts is to be regarded as the standard; thus itsuasuka, a horse, inay be pronounced itsiasika.

19. In acquiring the language, and making a correct analysis of its words, one of the greatest difficulties to be encountered is the interchangeability of certain consonants.

20. There are two important series of interchangeable consonants; a labial series consisting of $\mathrm{m}, \mathrm{b}$, and $\mathrm{w}$, and a clental, or linguodental, series consisting of $d, l, n$, and $r$. The constituent sounds of each series are subject to interchanges so arbitrary and frequent that no definite rules can be given for them. The following remarks, however, will be found to apply: ( $(\uparrow 21,22$ ).

21. $m$ is regarded as the standard letter of the labial series; it is the one most commonly used by those who are considered the best speakers of the language. Before the vowel $i, b$ is as commonly used as in in initial syllables, and w more commonly in median and terminal syllables.

22. $d$ is the standard of the dental series. When $r$ is substituted for d, it is more commonly done by men than by women, while the latter appear to have a greater preference for 1 and ' $n$ than the former. A desire for euphony seems sometimes to determine speakers in their choice.

23. Whenever, in any word, a non-essential letter is heard as often, or nearly as often, as its corresponding essential, the fact is shown in the Dictionary in one of three ways: 1st, by putting the modified syllable in brackets and indicating its position in the word by dashes, thins "liamua [-bu.]" and "liami [-wi]" denote that these words are very often pronounced liabua and liawi; 2d, by placing the entire modified word in brackets; and, 3l, by giving the modified word in its alphabetical order, referring to the same word with the standard spelling. Where a non-essential letter is heard oftener than the standard letter, the fact is shown by prefixing plus $[+]$ in the brackets, thas, "dopa [t mopa $]$.

\section{SYLLABLIS.}

24. The worls are divided into syllables in such a manner as to make the etymology as clear as possible. It is designed that each syllable shall represent one complete factor of a word, or, in case of contraction, more than one, but not the fragments of these factors joined together in an arbitrary way to simplify the task to the tongue and ear of the English-speaking student. 
25. A very large proportion of the syllables end with vowels. The more common cases in which they end with consonants are given below. (Тा $26-33$ ).

26. Initial and median syllables may end with c or k. (शा 27,28 ).

27. Syllables ending in $\mathrm{i}$ occasionally take $\mathrm{c}$ after $\mathrm{i}$ when another scrlable is suffixed ( $(15)$; this most frequently happens when the added syllable begins with $\mathrm{k}, \mathrm{p}$, or $\mathrm{t}$; thus we have micki from mi, and halipicti from halipi.

23. In the prefixes ak, dăk, and mạk, the $k$ is selılom transferred to the following syllable.

29. Terminal syllables (and consequently words) may end in $k, t, \dot{s}$, and ts. (โा 30-33).

30. A syllable may be closed by $\mathrm{k}: 1$ st, when verbs ending in ki form the imperative by dropping $i$, as amaki is changed to amak; $2 d$, when $a k$, duk, and tok are used as suffixes; $3 \mathfrak{a}$, when ak, dăk, or mạk stand alone; and, 4th, in the words duk, tok, and tsakak.

31. A syllable may be closed by $t$, when a verb euding in ti forms its imperative by dropping $i$, as kipsíti is changed to kipsít.

32. Proper names commonly end with $\dot{\text { s. }}$

33. A word which closes a sentence, or stands alone forming a sentence by itself, commonly terminates in ts, if not with $\mathrm{k}$, $\mathrm{t}$, or $\dot{\mathrm{s}} . \mathrm{ts}$ answers the purpose of a vocal period in most cases. ( $(168)$.

34. Syllables are frequently contracted by the elision of their vowels.

35. A contracted syllable, when not terminal, belongs to the succeeding syllable.

36. A syllable consisting of a single vowel, when following immediately an accented vowel, or standing immediately between two other vowels, may sometimes be omitted.

\section{WORDS.}

37. Words will be considered under the usual eight heads (articles excluded) of nouns, pronouns, verbs, adjectives, adverbs, prepositions, conjunctions, and interjections.

\section{Nouns.}

38. For conrenience of description, nouns may be divided into two c'asses, primitive and derivative.

\section{Primitive Nouns.}

39. Primitive nouns are such as, with our present knowledge of the language, we are unable to analyze either in whole or in part; as ma', snow ; i', mouth ; ista, eye, etc.

40. Nearly all the monosyllabic nouns are primitive, as are also the names of many things which are longest known to the people.

41. Many of the primitive nouns of the Hidatsa have, in kindred languages, their counterparts, which they closely resemble in sense and sound. 


\section{Derivative Noums.}

42. Derivative nouns are such as we are able to analyze in whole or n part.

43. Derivative nouns may be formed from words of any class, but chiefly from verbs, adjectives, and other nouns, either primitive or derived, by certain prefixes and suffixes, the commonest of which are i, adu, o, aku, ma, the possessive pronouns, and the diminutives dáka and káza.

44. i, prefixed to transitive verbs, forms nouns denoting the instrument or material with which the action is performed; thus, ita, an arrow, is from ta, to kill, and ikipạkisi, a tovel, from kipạkisi, to rub back and forth. Nouns formed in this way are commonly prefixed by other nouns (denoting the recipient of the action), by the prefix ma, or by both; thus, maikipạkisi, iteikipakisisi, and maiteikipạkisi are more commonly used than ikipakisis, although all these words denote the same thing. Nouns of the material are seldom heard without such prefixes; thus, maikikak, ithread (from kikaki, to sew), and maiteidusuki, soap (from ite, the face, and dusuki, to wash), are not heard in the simple forms of ikikaki and idusiuki.

45. adu (an adverb of time and place when used alone) is employed as a prefix to form nouns under the following circumstances: (IT 46-48).

46. adu, prefixed to verbs, forms nouns denoting the part on which the action is performed; as, adukikaki, a seam, from kikaki, to selo. Here ma, or the name of the thing to which the part belongs, precedes adu.

- 4i. adu is also prefixed to verbs to form nouns, which signify the place where an action is performed ; thus, from kidusiá, to put avay carefully, comes adukidusia, a place of deposit. In this case ma, or the noun denoting the object of the action, frequently precedes adu; e. g., maadukidusa, a place vore anything is put away or storen, matạkiadukidusia, a eupboard.

48. adu is prefixed to intransitive rerbs and adjectives to denote one or more of a kind or class which the rerbs or adjectives describe; thus, from idăkisa, left-handed, comes aduidakisa, a left-handed person, and from kiadetsi, brave, skillful, ete., comes adukiadetsi, one of the brave or skilled. In this case, ma usually precedes adu.

49. o, prefixed to a verb, may form therewith the name of the action; as in odídi, walking, gait, from dídi, to walk.

50. $o$ is used in the same way as adu, to denote the place where, or the part whereon, an action is performed; as in odhitsi, a mine, from dútse, to obtain.

51. aku (a relative pronoun when used alone), prefixed to a transitire rerb, forms a noun denoting the agent or performer of the act, and is nearly or quite synonymous with the English suffixes $e r$ and or. In this case, aku is commonly preceled by the name of the object; thus, 
from masipisia, grapes, and duti, to eat, we have masiipișaakudúti, grapeeater, i. e., the cedar-bird, or Ampelis cedrorum.

52. aku is sometimes used in the same sense as adu, in Par. 48. In this sense, it is common before the adjectives denoting color; as in akutohi, beads, from tohi, blue, and akusipisa, black cloth, from siipisa, black.

53. ma (to be distinguished from the pronoun ma) is a prefix of very extended use in the language. With some nouns, however, it is rarely used, while to a different class it is indispensable. It may be regarded as an indefinite particle, or as a unirersal noun or pronoun, qualified by the words to which it is prefixed. Some of the more common instances of its use are here given.

54. ma is prefixed to nouns of the instrument beginning with $i$, as in Paragraph 44, when the object on which the instrument is employed is not designated. When, for precision of definition, the object is named, its name takes the place of ma. When the name of the material of which the instrument is made is included, it commonly precedes ma; thus, from maidutsada, a sled, comes mida-maidutsada, a wooden sled.

55. ma is prefixed to adjectires to form the names of articles which possess in a marked degree attributes to which the adjectives refer; thus, from tsikoa, sweet, we have matsikoa, sugar.

56. ma is prefixed to verbs to form the names of objects on which the action denoted by the verb has been performed; thus, from kidutskisi, to wash out, comes makidutskisi, a lot of washed clothes.

57. Many words beginning with ma drop this prefix when incorporated with the possessive pronouns.

53. The possessive pronouns, (m), ma, mata, (d), di, dita, i, and ita, are placed before the name of the thing possessed; then, together, they are pronounced as one word, and the prououn regarded as a prefix.

59. In many cases, where possessive pronouns are prefixed, the noun denoting the thing possessed loses its first syllable, has its accent removed, or is otherwise much changed; as in itápa, his moccasins, from hupa, moccasins; itasi, his robe, from masii, a robe.

60. Some words are rarely, others nerèr,* heard without a prefixed possessive pronoun; as, itadsi, leggings, his leggings ; ișami, a father's sis. ter; itsuka, a man's younger brother.

61. But few words, formed as shown only in Par. 58, are given in the Dictionary, while all known words in the 3d person, formed as in Pars. 59 and 60 , are laid down. In the cases of such words as are referred to in Par. 60, as never being heard without a pronoun, the noun, with the pronoun omitted, is given sometimes as a hypothetical word.

* This construction is only found with names of things, which necessarily belong to some one, and cannot otherwise exist (as blood relations), or are usually so conceived (as certain articles of personal property), and only to a limited number of such names. 


\section{Diminutives.}

62. daka, which, when used alone, means the offspring or young of anything, is emplosed as a diminutive suffix of general application. Ex.-idaka, his or its young (the offispring of any individual or species mentioned); dalipitsidaka, a bear's cub, from dalipitsi, a bear; miiptsidaka, a hatehet, from miiptsi, an ax.

63. kaza is a diminutive suffix, whose use is limited to about twenty words of the language, including proper names. Ex.-masiakaza, a muppy, from masík a, a dog; - miakaza, a young woman, from mia, a woman ; amatikaza, the Little Missouri River, from amati, the Missouri.

64. The aljective kadista is also used as a diminutive.

\section{Compound Nouns.}

65. There are certain words which may be considered as compound nouns, because they closely resemble in structure compound nouns in Euglish; although no definite distinction can be made in Hidatsa between compound and other derived nouns, since the so.called prefixes and suffixes are really words-the most of them capable of being used alone.

66. Compound nouns are formed in the varions ways described in Pars. 44, 46, 47, 5t, and $5 \bar{j}$, and also by simply placing two or more nouns together or by joining nouns to verbs, adjectives, and adverbs; e. g., istamidi, tears, from ista, the eye, and midi, vater ; masitadalipitsisiu, bacon, from masis, white man, itadalipitsi, his bear, and súi, fat; istaoze, eye vash, collyrium, from ista, eye, and oze, to pour into ; itahats$\mathrm{ki}$, the Dakota Indians, from ita, arrows, and hatski, long; amasitakoamasi, the people of Prince Rupert's Land, from amasitakoa, at the north, and masi, white men.

67. When a compound noun is formed by simply placing two nouns together, the first word commonly denotes the possessor, the second the thing possessed. († 84).

68. Sometimes rerbs, adjectives, and adrerbs are used as nouns without undergoing any change of form; as oze, to pour, a drink; patsatikoa, at the west, the west.

\section{Properties of Nouns.}

\section{GENDER.}

69. Gender is distinguished by using, for the masculine and feminine, different words, which may either stand alone or be added to nouns of the common geuder.

70. matse, man, sikaka, young man, itaka, old man, the terms used for male relations (as itsuka, idiši, etc.), for callings exclusirely masculine, and the compounds of these words (as makadista-matse and itakalie), are nouns of the masculine gender, applied to the human species. 
71. mia, woman, kadulie, old woman, terms used for female relations (as idu, itakisia, etc.), for those emplosed in labors exclusively feminine, and the compounds of these (such as miakazi, a young usom in), are nouns of the feminine gender, applied to the human species.

72. kedapi, bull, when used alone, means a buffalo bull; but as a suffix, either with or without the interposition of alu, it designates the male of any of the lower animals.

73. mite, the generic name for buffulo, means also a buffalo cow.

74. mika, a mare, is used as a suffix to denote the females of the lower animals. It follows the specific name, with or without the intervention of adu.

75. When the species has been previously mentioned, or is otherwise understood, the specific name need not be prefixed to kedapi, adukedapi, mika, or adumika.

\section{NuMiber.}

76. Hidatsa nouns suffer no change of form to indicate the difference between singular and plural.

77. Some nouns we know to be singular or plural from their original meaning or from the sense in which they are used. In other cases, our only means of making a distinction is by the use of numeral adjectives, or such adjectives as ahu, mxny, etsa, all, kansta, few, etc.

\section{CASE.}

78. In view of their syntactical relations, Hidatsa nouns may be parsed as having the same cases as nouns of other languages; but they are not inflected to indicate case except, doubtfully, in the possessive.

79. Possession is ordinarily shown by the use of the possessive pronouns, which stand before the noun denoting the thing possessed, and are usually considered as prefixed to it.

80. Two kinds or degrees of possession are indicated in the language. One of these may be called intimate, integral, or non-transferable possession; such as the possession we have in the parts of our body, in our blood-relations ; the possession which anything has in its parts or attributes-the words idakoa, his friend or comrade, and iko'pa, her friend or comrade, are put with this class. The other kind, or degree, is that of acquired or transferable possession; it is the possession we hare in anything which we can acquire, or transfer from one to another.*

81. Intimate or non-transferable possession is shown by the use of the simple possessice pronouns, i, his, her, its, di, your, ma, my, and the contractions, $m$ and d. Ex._saki, hand, ișạki, his or her hand, disaki, your

* The terms here employed for the different classes of possession, as shown by the different kinds of pronouns, are the best which, at pressent, present themselves; but they do not accurately cover all cases. 
hand, masaki, my hand; iaka, a man's elder brother, diaka, your elder brother, miaka, my elder brother.

82. Transferable possession is shown by the compound possessire pronouns, ita, dita, and mata, which are formed by adding the syllable 'ta' to the simple pronouns. Ex.-milaki, a shield, itamidaki, his shield, ditamidaki, your shield, matamidáki, my shield.

83. The noun denoting the possessor is placed before the noun lenoting the thing possessed, and, when the former appears in a sentence, only the possessive pronoun of the third person can, of course, be used.

84. Possession may be indicated by simply placing the name of the possessor before that of the thing possessed, without the use of an intervening prononn ; the two words may be written separately, or as a compound worl $(\Phi \uparrow 6(i, 67)$, if the signification requires it. Some cases of this mode of showing possession may be regarded as simply an omission of the pronoun $i$; others, as the use of one noun, in the capacity of an adjective, to qualify another noun.

85. When the name of the possessor ends with a vowel, the ' $i$ ' of itat may be dropped, in which case the names of possessor and possessed, with the interposed 'ta', may be written as a compound word with a vowel or syllable elided, as shown in Pars. 34 and 36. But if we regard th ${ }_{3}$ ' $\mathrm{ta}^{2}$ ' as belonging to the noun denoting the possessor, we have as true a possessire case as is made by the English "apostrophe and $\mathrm{s}$ ". The possessive particle ta is never used alone as a pretix.

86. The position of a word in a sentence and the conjugation of the verb which follows, msually show whether it is in the nominative or objectire. Often, too, the case is rendered unmistakable by the meaning of the word and by the context.

\section{Proper Nouns.}

87. Proper names, whether of persons, domestic animals, or places, are nsually terminated with the consonant $\dot{s}$, if not already closed by another consonantal sound, as $\mathrm{t}$ or $\mathrm{k}$.

88. $\dot{s}$ may be regarded as the regular sign of a proper noun. It is well to end any proper name with $\dot{s}$, where another terminal consonant does not interfere, but it may be omitted when, in calling a person, we accent the last syllable of his name, when we annex the word azi to the name of a river, and occasionally under other circumstances.

89. $\dot{s}$ is not suffixed to the names of tribes or nations when the whole people are referred to. Perhaps such words are not regarded as proper. nouns by this tribe; but if the name of the tribe is used to distinguish one member of it, and is thus employed as a proper name, it takes the terminal s.

90. Words temporarily emplosed as proper names (as terms of relationship, etc.), may take the terminal ' $\dot{s}$, if there would be danger of ambiguity without it.

91. The name of a person mas consist of a single word, usually a 
noun; as, tsatsěś, Eagle (the spotted eagle), motsà, Coyote, amazis̀, Beans.

92. Personal names are, howerer, more commonly compound worls formed-(1) of two nouns; as, pedetskiliis (pedětska and ilii), Crow.crop, ista-uetsěs, Iron-eye;-(2) of a noun and a verb; as, tsakaka-amakis, sitting bird, dillipitsi-iduhis, Rising bear;-(3) of a noun and an adjective; as, tsesa-liadaliis, Lean-wolf, tsakaka-tohis, Blue bird;-(4) of a noun and adverb; as, midikoa-miis, Woman-at the water;-(5) of a pronoun, noun, and arljective; as, itamidaki.iliota! is, His-white shield,-_and in various other ways.*

93. Names of females often begin with the word mia (wia, bia), or end with mia, miis (wiis), all of which mean woman. Ex.-miahopas, Medicine-woman; miadalipitsis, Bear-woman; tsakakawiis, Bird-woman; matạ́liimiis, Turtle-voman.

94. Localities are named from physical peculiarities or historical associations. The names of various localities known to the tribe are appended to the Dictionary.

\section{Syntax of Nouns.}

95. A noun precedes a verb, adjective, noun in apposition, or any part of speech used as its predicate. Since there is no verb to be, used as in English, any word except a conjunction or interjection may be employed as the predicate of a noun.

96. The name of 'the person spoken to' commonly follows a verb in the imperative; but in almost all other cases a noun, whether subject or object, stands before the verb.

97. When the names of both subject and object appear, the former usually precedes the latter.

93. The name of the possessor precedes that of the thing possessed.

\section{PRONOUNS.}

99. Hidatsa pronouns may be divided into four classes, namely, personal, relative, interrogative, and demonstrative.

\section{Personal Pronouns.}

100: Personal pronouns are of two kinds, simple and compound.

101. Simple, or primary, personal pronouns consist, in the :ingular, of but one syllable; they may stand alone, as separate words, but are, usually found incorporated wi!h other words.

102. Compound personal pronouns consist of more than one syllable, are derived from simple pronouns, and, except those in the possessive case, are used as separate words.

103. Personal pronouns exhibit, by their different forms, their person, number, and case. 
104. They have the first, second, and third persons, the singular and plural numbers, and the nominative, possessive, and objectire eases.

\section{Simple Personal Pronouns.}

105. The simple personal pronouns are five in number; they are ma and $\mathrm{mi}$ (sometimes contracted to $\mathrm{m}$ ) for the first person, da and di (sometimes contracted to d) for the second person, and $i$ for the third person.

106. They stand alone when used for repetition and emphasis, but otherwise are incorporated with other words.

107. ma, $I$, and da, thou, are the proper nominative forms; they are used as the nominatives of transitive verbs, but may also be employed as the nominatives of certain intransitive rerbs which have an active sense; as, amáki, he sits, amamaki, I sit, adamaki, you sit, They may be prefixed or suffixed to, or inserted into, verbs; thus we have kikidi, he hunts, makikidi, I hunt, dakikidi, you hunt; kạtsihe, he extinguishes, kà. tsima, I extinguish, katsida, you extinguish; akakạsi, he urites, amakalị̣si, I urite, adakakạsi, you ucrite.

J118. ma, $m y$, is used in the possessive case, prefixed to the nom denoting the thing possessed, in intimate or non-transferable possession; as in masaki, my hand, from saki, hand; matsi, my foot, from itsi, his foot. (T 81 ).

119. $\mathrm{mi}$, me, di, thee, and $\mathrm{i}$, him, her, it, are prefixed to transitive verbs to denote the object; as, from kidesi, he loves, we have mikides; he loves $m e$, dikidesi, he loves thee, ikidesi, he loves him, her, or it, midakideši (me thou lovest), you love me, and dimakidesi (thee I love), I love you.

110. mi and di are, however, used as the nominatives of such intransitive verbs as imply only quality or state of being, and of qualifying words used as rerbs.

111. di, thy, your, and i, his, her, its, theirs, are also used in the possessire case, prefixed to the name of the thing possessed, to denote noutransferable possession. (I 81). Examples.—disaki, your hand, ișaki, his hand, from saki, hand; ditsi, your foot, itsi, his foot (the hypothetical word, tsi, is not used without the possessive pronouns).

112. ma and $\mathrm{mi}$, da and di, are commonly contracted, when placed before vowels, according to orthographic rules already given (Iף 34,35 ); as in makulii, my ear, dakulii, your eur, from akulii, ear ; mișta, my eye, dista, your eye, from isita, eye.

113. The possessire pronoun, $i$, is often omitted before words beginning with a rowel, where possession is intimated; thus, akulii, ear, is also his or her ear; ista, eye, also his or her eye.

114. When the pronoun of the third person, singular, stands alone, it is often pronounced hi.

115. The plural forms of simple pronouns are not incorporated; they are mido, plural of ma and $\mathrm{mi}$; dido, plural of da and di; and hido, plural of $i$. 


\section{Compound Personal Pronouns.}

116. The compound personal pronouns are formed from the simple pronouns by means of suffixes. The words most readily recognizable, as of this class, are micki, dicki, and icki (with their plurals), and the possessives, mata, dita, and ita.

117. micki (1st person), dicki ( 2 d person), and icki ( $3 \mathrm{~d}$ person) are used in an emphatic and limiting sense, and are nearly synonymous with the English words myself, thyself, and himself or herself. They may be used alone, as nominatives or objectives to verbs, but are commonly repetitions, being followed by the simple incorporated pronouns with which they agree.

118. Their plurals, used in the same way as the singular forms, are midoki (ourselves), didoki (yourselves), and bidoki (themselves).

119. máta, my, our, díta, thy, your, and ita, his, her, its, their, are compound possessire pronouns, which are ordinarily used to indicate an

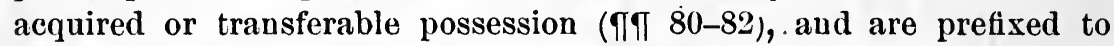
nouns, denoting the thing possessed. ( $($ 8 83 ).

120. In compound words, formed of the names of possessor and pos. sessed with the pronoun ita, the i of ita may sometimes be dropped. ( $\Upsilon$ T 36,85 ).

121. mata, dita, and ita have not separate forms for singular and plural.

122. The words matamae ( 1 st pers.), ditamae ( $2 d$ pers.), and itamae (3d pers.), are used respectively as the equivalents of the English words mine or my own, thine or thy own, and his, hers, its, theirs, or his own, etc., and also as the equivalents of the Dakota words mitawa, nitawa, and tawa. The Hidatsa words, however, I regard not as pronouns, but as nouns formed by prefixing the compound possessive pronouns to the noun 'mae'. According to the usual custom with interchangeable consonants, these words are often pronounced matawae, nitawae, and itawae.

\section{Synopsis of Personal Pronouns.}

Simple.

Singular.

Plural.

1st pers. $\left\{\begin{array}{l}\text { nom., ma and mi. } \\ \text { poss., ma. } \\ \text { obj., mi. }\end{array}\right.$

all cases, mido.

$2 \mathrm{~d}$ pers. $\left\{\begin{array}{l}\text { nom., da and di. } \\ \text { poss., di. } \\ \text { obj., di. }\end{array}\right.$

all cases, dido.

$3 d$ pers. $\left\{\begin{array}{l}\text { nom., }\{\text { ( }(133) \text {. } \\ \text { poss., i. } \\ \text { olj., i, or hi. }\end{array}\right.$

all cases, hido. 
Compound.

With ' $\mathrm{ki}$ ' for emphasis and limitation.

Singular.

1st pers., micki.

$2 d$ pers., dicki.

3 ll pers., icki.
Plural. midoki. didoki. hidoki.

With ' ta' to denote transferable possession.

Singular and Plural.

1st pers., mata.

2d pers., dita.

$3 d$ pers., ita.

\section{Relative Pronouns.}

123. The interrogatives tapa, what? tapé, who? aku ( 9 IT 51,52), and s me other words are used as relative pronouns.

\section{Interrogative Pronouns.}

124. Interrogative prononns, and all other interrogative words of the linguage, begin with $t$, which, being always followed by a vowel in these words, has a slight sound of English th in tiing. († 5).

125. tapé, who? tapa, what? taka, what? to, which or where? tua, which? how? are the principal interrogative pronouns.

126. Their compounds, tapeitamae, whose? tapata, takata, tota, whither? todu, where? tuami, how many? etc., etc., are sometimes used as pronoms, although usually filling the offices of nouns, adjectives or adverbs.

\section{Demonstrative Pronoums.}

127. The demonstrative pronouns are hidi, this, hido, that, with ku and is or sia, that, him, distinctive oz emphatic forms.

12s. Their componnds are bidimi, this many, hidika, this much, hiduka, this way, kutapa, what is that? kuadu, that place, kutsaki, setsaki, that alone, sedu, just there, etc., etc. These, like the compounds of interrogative pronouns, are used as pronouns, but more commonly as other parts of speech.

\section{Syntax of Pronouns.}

129. All simple pronouns in the objective case, or used separately for emphasis, and usually all compound pronouns in any case, precede the verb.

130. Personal pronouns in the objective commonly precede those in the nominative. 
131. When $\mathrm{mi}$ or di is used as the nominative of an intransitive rerb ( $\uparrow 110$ ), or of any word used as such, it stands before the verb.

132. When ma or da is used as an incorporated pronoun in the nominative ( $(107)$, its position in the verb is usually determined as follows: (1st) In a verb formed directly from a verbal root and beginning with ans consonant (except $m$ followed by a), the pronom is prefixed in the indicative; as in kikis̉ki, he measures, makikisiki, I measure, dakikiski, you measure; patsaki, he cuts, mapatsaki, I cut, dapatsạki, you cut. ('Đi) In a verb formed directly from a verbal root and begiuning with a vowel, or the syllable ma, the pronoun is inserted in the indicative; while the verb, if beginning in the third person with $\mathrm{i}$ or $\mathrm{o}$, is made to begin with a in the first and second persons. Ex.-asiadi, he steals, amasidadi, $I$ steal, adaśadadi, you steal; maihe, he tries, mamahe, I try, madahe, you try; iku'pa, he hates, ànaku'pa, I hate, adlaku'pa, you hate; odapi, he discovers, amodapi, I discover, adodapi, you discover. (3d) In a transitive verb formed from an intransitive verb by the addition of be, ha, or ki", the pronoun is suffixed.

133. There is no incorporated pronoun in the third person nominative.*

134. The use of incorporated pronouns being necessary to the conj:1gation of rerbs, they cannot be omitted when several verbs refer to the same subject or object.

135. Incorporated possessive pronouns must be prefixed to the name of each thing possessed, even when but one possessor is indicated.

136. A demonstrative, relative, or interrogative pronoun usually stands at the beginning of the clause to which it belongs.

137. When a relative and demonstrative pronoun appear in the same sentence, the clanse containing the former usually stands tirst.

138. Some modifications of the above rules will be discussed under the head of verbs.

\section{VERBS.}

139. Almost any word in the language may be used and conjugaterl as an intransitive verb, and may again, by certain suffixes, be changed to a transitive verb, and be conjugated as such.

140. Adjectives, nouns, adverbs, and prepositions are often thus treated; pronouns, conjunctions. and interjections rarely.

141. But there is a large number of words in the language which are used only as verbs and are not derived from other parts of speech; these may be called verbs proper.

142. Many verbs proper we cannot analıze, and therefore consider them as primitive verbs. Such are ki, to bear or earry; hu, to come; de, to depart; eke, to know, etc.

* Pussibly in maihu and maihe we bave exceptions to this rule. (I 199). 
143. Other verbs proper, which we call derivative, are formed, by the use of certain prefixes and suftixes, from rerbal roots, from primitive verbs, and from other derivative verbs.

\section{Verbal Roots.}

144. Verbal roots are not used as independent words. A great number have been found in the language; but satisfactory meanings have been discovered for'a very few only, some of which are here given for illustration : liapi, bark, peel ; liese, tear through ; liolii, break across ; lin, spill, overset; kahe, sprend, siretch ; kạpe, teur ints, lacerate; kạtsi, notch; kide, push; kiti, clear off; ktade, pound in, peg; midl, tıcist; mitsi, mince; unu, make noise; mudsi, roll up; papi, roughen, chap; pi, penetrate; plin, or pliuti, squeeze or press out ; pkiti, smooth out (? fr. kiti); psiu, dislocate; ptsu or ptsuti, thrust forth; sippi, loosen; sंki, open out; sku, extruct; suki, erase ; tal, destroy ; tạki, place in contact, shut; tạpi, squeeze; tsil, sepurate; tsidla, slide; tsit'ti, stick, polish; tsiti, raze; tski, squeeze on a small surfuce from different directions, shear, strangle, etc.; tskipi, pare; tskise, erash; tskupi, bend. Some of these may be modified roots, containing something more than the simplest radical rdea, but could not be well further aualyzed.

\section{Prefixes and suffixes.}

145. Some of the prefixes and suftixes referred to are independent words, but many of them are used only when connected with verbs. Some are to be regarded as adverbs, others perhaps as auxiliary verbs.

\section{Prefixes.}

146. The more important prefixes, whose meaniugs have been determined, are ada, ak, da, dak, du, ki, mạk, and pa.

147. ada immediately precedes the root, and denotes that the action is performed by the foot, or by means of heat or fire; as in adaliolii, to break across with the foot, from liohi, break across, and adakite, to clear off by fire, as in burning a prairie, from the root kite, clear off.

14s. ak denotes that the action is performed with or on something; as, aksंuĕ, to spit on, from suĕ, to spit.

149. da denotes that the action is done, or may properly be done, with the month; it stands immediately before the root, aud is often pronounced ra or lia. Ex.-latsi, to bite off, from tsa, separate; daliesie, to tear with the teeth, from the root liese, tear.

150. dăk (or dăka) stands immediately before a root or rerb to denote that the action is performed with a sudden forcible impulse, or with great force applied during a short time, and usually repeated at short intervals; as in daktsạki, to chnp, from tsaki, cut; dakaliohi, to break across with a blow, from the root lioli, break across. $\mathrm{n}$ is often used as the initial sound of this pretix. 
151. du is prefixed to roots, to convert them into verbs, without materially adding to their significance; it may be said to denote general or indefinite cansation; is sometimes pronounced ru or lu. Ex.-duliolii, to break across in any way or by any means, from liolii, break across; dumidi, to twist in any way, from the root midi, twist.

152. ki is sometimes added directly to verbal roots, but more commonly to rerbs. It may be added to any verb, no matter how formed, and is the most extensively used verbal prefix in the language. It intensifies the meaning; denotes that the action is done forcibly, repeatedly, completely, with difficulty, or over the entire object. Some. times it merely strengthens, without altering the meauing of the verb; in other cases, it totally changes its application. Some verbs are never used without it. Ex.-dalipa, to put the arms around, kidalipa, to huf; pati, to fall down, kipati, to fall from a great height. The words kime, to tell, and kidesi, to love, have not simpler forms.

153. mạk (or mạki) is prefixed to verbs to denote opposition or reciprocity; that the action is performed by two contending parties, that the motion is from opposite directions, that two actors mutually and reciprocally perform the action; thus, from pataki, to close, comes makipataki, to elose anything which has both sides moved in the act, as a book or a pocket-comb, and from iku'pa, to hate, mạkiiku'pa, to hate mutually, to hate one another.

154. pa is a cansative prefix, denoting that the action is done by the hand, or by an instrument held in the hand, or that it may be properly so performed. It stands immediately before roots and primitive verbs. Ex.-palin, to pour with the hand, from liu, spill; pamidi, to twist with the hand, from midi, tuist.

\section{SUFFIXES.}

155. The principal suffixes to verbs are adsi, adui, de, he, ha, ke, ksंa, and ti, with duk and tok for the subjunetive, di, diha, mi, and miha for the future indieative, and ts for the closing of sentences.

156. adsi denotes a resemblance or approach to the standard described by the simpler form of the verb; it is most commonly, however, used with adjectives, rarely with verbs proper. (\$ 226). Ex.-mitapa, to lie, to deceive, mitapadsi, to equivocate.

157. adui denotes progression and incompleteness in action on condition; it answers sometimes the purpose of the English termination ing in present participles. Verbs ending in adui are intransitive and usually preceded by ki. Ex.-titsi, thick, titsadui, or kititsadui, gradually increasing in thickness; isia, bad, isiadui, deteriorating, to become progressively worse.

158. Verbs lose their final vowels when adsi and adui are suffixed.

159. de may be trauslated, almost, nearly, about to, and denotes an incomplete action or condition. It is added to, and forms, intrausitive 
verbs. Ex.-tsipiti, to full upon the water, to be in a condition to sink, tsipitide, to be about to full, or nearly fulling, on the water.

160. he, signifying generally to make or cause, changes some intransitive verbs, and words used as such, to transitive. Verbs take it in the third person indicative, but rarely retain it in the first person; while in the second person indicative, and in the imperative, it is dropped or changed to ha. The incorporated pronouns are suffixed to rerbs furmed by the addition of he, which suffix they sometimes follow, but more commonly replace. Ex.-komi, complete, finished, komilie, he finishes, komima, I finish, komida, you finish, komihada, finish thou!

161. ha is the form of 'he' used in the second person.

162. ke, signifying to cause, to change, to use for, is added to intransitive verbs, to form transitive verbs. It is more extensice in its application than he, and may be alded to any of the numerous words of the language which are capable of veing used as intransitive verbs. It is retained in all persons, tenses, and modes, and followed by the incorporated pronouns. When ke is suftixed, the verb is most commonly put in the intensive form. The more faniliar instances, only, of its use are given in the Dictionary. Ex.-hisi, red, hisike, to dye or color red, dyed red; isia, bad, isiake, to make bad, change from good to bad, damaged, debased, kiisiake (intensive), he damages, kiisiakema, I damage, kiisiakeda, you dumage; ati, a house, kiatike, to use for a duelling, or convert into a dicelling; midi, water, kimidike, to liquefy.

163. ksa denotes that an action is performed habitually or excessively, or that a quality exists to a constant or excessive degree; it is used with verbs proper and adjectives. Ex.—mitapa, to lie or deceive, mitapaksia, to lic habitually or excessively; ide, to speak, ideksia, to speak garrulously or unguardedly, to say too much. (I 231).

164. ti, denoting a favorable condition or readiness to perform an act, is added to intransitive verbs, forming new intransitive verbs. Ex.lua, to cough, huati, to be about to cough, to feel a desire to cough; halipi, to sneeze, halipicti, to desire to sneeze; tsipi, to sink, tsipiti, to fall upon the vater, to be placed in c condition fuvorable for sinking.

165. duk, used alone as an adverb of future time, is suftixed to subjoined verbs, to denote doubt or condition in regard to future time, and is therefore equivalent to a sign of the subjunctive mode in the future tense. Ex.-miadéheduk ditamamits, if I am angered, I will kill you.

166. tok, an adverb used to denote doubt and interrogation, is usually used independently, but may be suffixed to verbs to indicate the past and present teuse of the subjunctive mode; as in madetok diamakatats, had I gone, I rould not have seen you.

167. di (2d person singular), diba ( $2 \mathrm{~d}$ person plural), mi (1st person singular), and miha (1st person plural) denote the future teuse, indicative mode, and may follow any verb which takes ma and da for its incorporated nominative pronouns. They have the appearance of being 
only repeated pronouns, but are probably different forms of a regularly conjugated anxiliary verb.

16s. A verb, or any worl used as such, in the indicative mode, when closing a sentence, and therefore when standing alone and forming a sentence by itself, is terminated in ts; if in other situations it ends in in vowel. (I 33). By comparison of this with previous rules, it will be seen that a large majority of the words of the language are capable of receir. ing this termination. In the conjugations following, some of the verbs are shown with the terminal ts. (शा 196, 193).

169. ta' (not) and ta (only) are often pronounced as if suffixed; they are regarded, however, as independent alverbs.

170. There are verbs which are heard to end sometimes in i and sometimes in e, and apparently when a passive sense is meant by the former and an active by the latter. Owing, however, to the indistinct inanner in which final rowels are so ofte: liberties taken with rowel somds, the value of this peculiarity, as a grammatical rule, cannot now be estimated. A few words, where this change of terminal vowels was often beard, are given in both forms in the Dictionary.

171. Many rerbs ending in $i$ or e change these letters to a in the second person indieative, and also in the imperative, when the final $i$ or $e$ is not dropped.

\section{Properties of Verbs.}

\section{Person.}

172. The first and second persons are shown by the incorporated pronouns, ma and mi for the former, da and di for the latter. The third person is shown by the simple form of the verb.

\section{NuMBer.}

173. In the conjugation of the verb, number is indicated only in the future indicative, where $\mathrm{mi}$ and $\mathrm{di}$ are used in the singular, for the first and second persons respectively, and miha and diha in the plural. (T 167).

\section{MODE.}

174. Three modes ouly, the infinitive, indicative, and imperative, are shown in the conjugations of verbs. The subjunctive and potential are indicated by adverbs or alditional verbs.

\section{Infinitive.}

175. The intinitive mode is the same as the third person indicative, the simple form of the verb. It is, however, rarely used, finite ve:bs being employed instead; thus, "[ try to congh" is more frequently ren. dered mahua manahets, $I$ cough $I$ try, than hua mamahets, to cough 
176. In the third person, no distinction is made between the infinitive and indicative; thus, hua maibets may be rendered either to congh he tries or he coughs he tries.

\section{Indicative.}

177. The simple form of the verb is used as the third person indicative. For the first and second persons this is modified by the incorpo. rated pronouns; and for the future tense, as shown in Pars. 167 and 173.

\section{Imperative.}

178. The imperative mode has five forms.

179. The first consists in using the same form as the second person indicative; this is done mostly in verbs which have the incorporated pronouns suffixed.

180. The second is made by changing final $i$ or $e$ of the infinitive to a, or using an intinitive ending in a or u.

181. The third is formed by dropping the final $i$ of verbs ending in $k i$, and sometimes of those ending in ti; thus, we have anak, imperative of amaki.

182. In the fourth form, the auxiliary da is added to the second form of the imperative; it is usnally, but not iuvariably, placed after the verb. da seems to be a furm of the verb de, to depart, meaning go thou!

183. The fifth form of the imperative mode is made by adding dihs instearl of da.

184. The fourth and fifth forms are used when immediate compliance with the order is desired.

\section{Trise.}

185. But two distinctions, in regard to time, are made in conjugating rerbs; one of these is for indefinite, the other for future time.

186. Other varieties of time are expressed by adverbs, suffixed or independent, or by other words used independently.

187. The indefinite tense, used for both present and past time, is shown by the simple form of the rerb, with or withont the incorporated pro. nouns.

188. For the future tense, indicative mode, mi and miha are added to the indefinite for the tirst person, and di and diba for the second person; in the third person, the form is the same as in the indefinite.

189. Sometimes, to a verb in the third person, future tense, at the close of a sentence, they are heard to ald hits, prononncing it as a sep. arate word. This may be a part of the conjugation, bnt is, more prob. ably, a personal pronoun of the thirl person, hi, with the ending ts, added for emphasis. 


\section{CONJUGaTion.}

190. All transitive and some intransitive verbs are properly conjugated, having different forms for the different modes and tenses.

191. The greater part of the intransitive verbs, and words used as such, are not properly conjugated, since they suffer no change of form in the different modes and tenses.

192. The verbs which are conjugated may be known by taking ma (I) and da (thou) for their incorporated pronouns in the nominative; while those which are not conjugated have the pronouns mi and di in. corporated in the nominative case.

\section{Conjugated Verbs.}

193. The conjugation has three principal forms. In the first form, the pronouns are prefixed; in the second, inserted; and, in the third, suffixerl.

194. In adding the pronouns, however, some additional changes are made in the verb, producing in all ten varieties of the conjugation.

195. In the first variety, the incorporated pronouns are simply prefixed to the third person, or simple form of the rerb; while the latter remains unchanged. Ex.-killĕsi, to love, or he loves.

\section{INFINITIVE MODE. \\ kiděsi, to love. \\ INDICATIVE MODE. \\ Indefinite T'ense. \\ Singular and Plural.}

$3 d$ person. kidĕsi, he, she, or it loves or loved, they love or loved.

$2 d$ person. dakiděsi, thou lovest, you love or loved.

1st person. makudĕsi, $I$ or we love or loved.

Future Tense.

Singular.

$3 d$ person. kiděsi, he, she, or it will love.

2d person. dakedèsidi, thou wilt love.

1st person. makiděsimi, I will love.

Plural.

$3 d$ person. kiděsi, they will love.

$2 d$ person. dakiděsidiha, you will love.

1st person. makiděsimiba, we will love.

\section{IMPERATIVE MODE.}

kiděs̀a, kiděṡada, kiděs̆adiha, love thou, love ye.

196. In the second rariety, the first letter of the simple form is dropperl when the pronouns are prefixel, and the pronoms are contracted to $\mathrm{m}$ 
and d. The words belonging to this variety are not numerous; they all begin with d, and consequently in the indicative mode, indefinite teuse, the forms of the second and third persons are the same. Ex.-dúti, to eat, to chew.

INFINI'IVE MODE.

duti, to chevo or eat.

INDICATIVE MODE.

Indefinite Tense.

Singular and Plural.

(without terminal ts.)

3 d person. duti, he eats, etc.

$2 d$ person. duti, you eat, etc.

1 st person. muti, I eat, etc. (with terminal ts.) dutĩts. dutrits. mutrts.

Future Tense.

Singular.

$3 d$ person. duti, he will eat, ete. dutrits.

ad person. dutidi, thou wilt eat. dutidirts.

1st person. mutimi, I rill eat. mutimits.

\section{Plural.}

$3 d$ person. duti, they will eat. dutrts.

ad person. dutidiha, you vill ext. dutidihats.

1st person. mutimiha, we will eat. mutimibats.

IMPERATIVE.

dut. da' dut, etc. eat, eat thọu.

197. The third variety of the conjugation has the pronouns prefixed to the unaltered simple form; but the letter a is in turn prefixed to the pronouns, cansing them to appear inserted in the verb; further, the pronouns are contracted by the omission of their vowels. Most verbs bəginning with o belong to this variety. Ex.-ókipapi, to find, to recover something lost, but not to make an original discorery.

INFINITIVE MODE.

okipapi, to find.

Indicative Mode.

Indefinite Tense.

Singular and Plural.

3 d pers. okipapi, he, she, or it finds, or found, or they, etc.

$2 d$ pers. adokipapi, you find or found.

1 st pers. amokipapi, $I$ or we find or found. 
Future Tense.

Singular.

$3 d$ pers. okipapi, he, she, or it will find.

$2 d$ pers. arlokipapidi, thou wilt find.

1st pers. amokipapimi, I will find.

Plural.

$3 d$ pers. okipapi, they will find.

$2 d$ pers. adokipapidiha, you will find.

1st pers. amokipapimiba, we will find.

IMPERATIVE MODE.

okipapa, okipapa dạ́, okipapa diba.

19S. In the fonrth variety, the incorporated pronouns are inserted in the verb by being placed immediately after the first syllable of the sim. ple form, while no change is made in the latter, except the separation of the sy llables. Verbs conjugated thus have a or e for their first syllables. kx.-éke, to know, to recognize.

\section{INFINITIVE MODE. \\ eke, to know.}

Indefinite Tense.

Singular and Plural.

(withont terminal ts.) (with terminal ts.)

$3 d$ pers. eke, he, etc., knous, or knew. ekěts.

$2 d$ pers. erlake, you know or knew. elakěts.

1st pers. emake, I know or knew. emakĕts.

Future Tense.

Singular.

3d pers. eke, he, ete, will know.

ekěts.

ad pers. edakedi, thou wilt know. edakedǐts.

1 st pers. emakemi, I will know.

emakemirts.

Plural.

$3 d$ pers. eke, they will know.

$2 d$ pers. edakediha, you will know.

1st pers. emakemiha, we will know.

ekěts.

edakedihats.

emakemiluats.

\section{IMPERATIVE MODE. \\ eka, eka da', eka diha.}

199. 'To' the fifth variety, belong verbs beginning with ma. In it, the incorporated pronouns come after the first syllable, and are substituted for the second syllable of the simple form, which is, therefure, changed by the loss of a syllable. Ex.-mailiu, to trade, to buy. 
IIDATSA GRAMMAR.

INFINITIVE MODE.

maibu, to trade.

INDICATIVE MODE.

Indefinite Tense.

Singular and Plural.

$3 d$ pers. Inailu, he or she trades or traded, they, etc.

$2 d$ pers. madahu, you trade or traded.

1st pers. mamahu, I or we trade or traded.

\section{Future Tense.}

Singular.

$3 d$ pers. maihu, he or she will trade.

$2 d$ pers. madaliudi, thou wilt trade.

1 st pers. mamahumi, I will trade.

Plural.

$3 d$ pers. maihu, they will trade.

$2 d$ pers. malahudiha, you vill trade.

1st pers. mamahumila, we vill trade.

\section{IMPERATIVE MODE.}

madahu da', maihu da'.

200. In the sixth variety, the incorporated pronouns are inserted in the sane way as in the fourth; but the syllable da is inserted, in the first and second persons, immediately before the last syllable of the verb. This extra interpolated syllable does not seem to ainswer the pmrpose of either pronoun, adverb, or anxiliary; its utility has not been liscorered. aśádi, to steal, atáli, to go out of a house, and perhaps a few other verbs, are conjugated in this way.

\section{INFINITIVE MODE. \\ aśadi, to steal. \\ INDICATIVE MODE. \\ Indefinite Tense.}

Singular and Plural.

$3 d$ pers. asiadi, he or she steals or stole, they stent or stole.

2d pers. adasiadadi, you steal or stole. .

1 t pers. amasiadadi, $I$ or we steal or stole. 
Future Tense.

Singular.

$3 d$ pers. asiali, he or she will steal.

$2 d$ pers. adasidadidi, thou wilt stenl.

1st pers. amaśadadimi, I will steal.

\section{Plural.}

$3 d$ pers. asiadi, they will steal.

2d pers. adasiadadidiha, you ucill steul.

1st pers. amasiadadimiha, we will steal.

IMPERATIVE MODE.

as̉ada da', aśada diha.

201. To the seventh rariety belong rerbs beginning in $\mathrm{i}$ (not the incorporated pronom of the third person objective). Here the incorporated pronouns are inserted, but $\mathrm{i}$ is changed to a. Er.-íka, to see.

INFINITIVE Mode.

ika, to see.

INDICATIVE Mode.

Indefinite Tense.

Singular and Plnral.

$3 d$ pers. ika, he or she sees or saw, they see or saw.

$2 d$ pers. adaka, you see or saw.

1 st pers. amaka, $I$ or vee see or sau.

Future Tense.

Singular.

$3 d$ pers. ika, he or she vill see.

$2 d$ pers. adakadi, thou wilt see.

1st pers. amakami, I will see.

Plural.

$3 d$ pers. ika, they will see.

$2 d$ pers. adakadiha, you will see.

1 st pers. amakamiha, we will see.

IMPERATIVE MoDE.

ika, ika da', ika diha.

Besides these, ika has a reduplicated form in the imperatire, used in an exclamatory manner, ikaka! See there! Behold! 
202. The eighth variety is distiuguished by the iucorporated pronouns of the nominative being substituted for the last syllable of the infinitive form. Nearly all transitive verbs formed from intransitive verbs by the suffix he belong to the eighth variety. Ex.-liạpihé, to lose.

\section{INFINITIVE MODE. \\ liapihe, to lose. \\ Indicative MoDe. \\ Indefinite Tense.}

Singular and Plural.

$3 d$ pers. liạpihe, he or she loses or lost, or they lose or lost.

2 ll pers. liapida, you lose or lost.

1 st pers. liapima, I lose or lost, or we lose or lost.

Future Tense.

Singular.

3 ll pers. liapihe, he vill lose.

2d pers. liapidadi, thou vilt lose.

1st pers. liạpimami, I will lose.

Plural.

$3 d$ pers. liapihe, they will lose.

2d pers. liappidadiha, you vill lose.

1st pers. liapimamiha, ve vill lose.

IMPERATIVE MODE.

liạpida, da' liạpida, liạpihada.

203. The ninth rariety is the same as the eighth, with the addition of the simple possessive pronouns, in full or contracted, prefixed to the verb. In this variety are found but few verbs; they are formed from nouus by the addition of the suffix he; they undergo a double inflection, one to denote possession of the noun, and the other to show person, tense, etc., in the verb. Ex.-uiahe, to make or cause to be a wife, to wed, from ua, a vife. nahe, in its active sense, or used personally, is said of the male.

\section{INFINITIVE MODE.}

uahe, to make a vife, to wed.

INDICATIVF MODE.

Indefinite Tense.

Singular and Plural.

$3 d$ pers. uahe, he makes his vife, he or they wed or wedded, etc.

$2 d$ pers. duada, you make your wife or vives, you wed or vedded, etc.

1st pers. muama, I make my wife, I or we wed, etc. 


\section{Future 'Tense.}

Singular.

$3 d$ pers. uahe, he will make his wife, or wed.

$2 d$ pers. duadadi, thou wilt make thy wife, or wed.

1st pers. muamami, I will make my wife, or wed.

\section{Plural.}

$3 d$ pers. uahe, they will make their wives, or wed.

2d pers. duadadiha, you will make your wives, etc.

1st pers. muamamiha, we will make our wives, or wed.

\section{IMPERATIVE MODE.}

duada, duaha da', duaha diha.

201. In the tenth variety, the pronouns are suffixed to the simple form, which in itself remains unchanged. Transitive verbs formed from the intransitive by the addition of ke are conjugated in this way. Ex.kitsakíke, to render completely good, to make whole or sound, to change from bad to good, etc., from tsạki; good.

\section{INFINITIVE MIODE.}

kitsạkike, to make good.

Indicative Mode.

Indefinite Tense.

Singular and Plural.

$3 d$ pers. kitsakike, he, she, it, or they make or made good.

$2 d$ pers. kitsakikeda, you make or made good.

1st pers. kitsạkikema, I or we make or mate good.

\section{Future Tense.}

\section{Singular.}

3 ll pers. kitsakike, he, she, or it will mahe good. $2 d$ pers. kitsạkikedadi, thou wilt make good. 1st pers. kitsakikemami, I will make good.

\section{Plural.}

$3 d$ pers. kitsakike, they will make good,

$2 d$ pers. kitsạkikedadiba, you will make good.

1stpers. kitsakikemamiha, we will make good.

\section{IMPERA'TIVE MODE.}

kitsạkikeda, kitsakike diha. 


\section{Unconjugated Verbs.}

205. All adjectives, adverbs, nouns, etc., used as predicates of nouns, are regarded as intransitive verbs, there being no copula in the language. These intransitive verbs, and such others as denote only quality or condition, suffer no change of form to denote different morles and tenses. They may, howerer, take the incorporated pronouns mi aud di for their nominatives.

206. These pronouns are nrefixed. To verbs beginning with consonants they are usually prefixed in full. Ex.-liié, old, to be old.

liie, he, she, or it is or was old, they are or were old.

diliie, thou art or vert old, you are or vere old.

miliie, I am or was old, we are or were old.

207. Before verbs beginning with vowels, the pronouns are often contracted. Ex.-adáliise, to be ignorant.

adaliise, he is or was ignorant, they are or are ignorant.

dadaliise, thou art or uert ignorant, etc.

madaliise, I am or was ignorant, or ve tere ignorant, ete.

208. Transitive rerbs in the third person, or used in a passive sense or impersonally, with pronouns in the objective case prefixed, have the same appearance as the unconjugated intransitive verbs, except that for the third person the objective pronoun $i$ is used; thus, from alio.l, to conceal, we have

ialioa, he conceals it, or it is concealed.

dialioa, he conceals you, or you are concealed.

mialioa, he conceals me, or I am concealed.

\section{Irregular and Defective Verbs.}

209. There are a few irregular and defective rerbs in the language, of which the following are examples:

210. hi, to draw into the mouth, to drink or inhale, may, with terminal ts, be conjugated thus:

1. hits, he drinks or drank or will drink, they drink, etc.

2. dats, you drink or drank.

3. unats, $I$ drink or drank.

4. dadits, you will drink.

5. mamits, I will drink.

Here, in the fourth and fifth forms, there are (with the terminal) but the pronouns and signs of the future tense, and in the second and third forms, only the pronouns.

211. matú, there is or there are, has no other forın.

212. muk (sometimes pronounced as the Euglish word book) signifies gice me. It may be an irregular imperative of the verb ku, to give, but is more probably a defective verb. 


\section{Compound Verbs (so called).}

213. Sometimes two verbs are used together to express an idea for which there is no single word in the language. When both verbs are in the third person indicative, or when one is in the infinitive, they often appear to us as a single word, particularly if their English equivalent is a single word; but when conjugated, it is found that each assumes its own proper furm, the same as if used inclependently. Ex.-ákhu, to. bring, consists of ak, to be with, and hu, to come. This, when inflected, appears as two separate words, one conjugated, the other unconjugated; thus, ak-hu, he brings; dak-dahu, you bring; mak-mahu, I bring; dakdahudi, you will bring; mak-mahumi, I will bring, ete.

214. Again, a noun and a verb may be used together to express an illea for which there is no single word in the language; thus, from hi, to draw into the mouth, we have ope-hi, to draw tobacco into the mouth, i.e., to smoke, and midi-hi, to draw water into the mouth, or drink.

215. Some expressions, such as these, are, for convenience of definition, put in the Dictionary as componnd verbs.

\section{Syntax of Verbs.}

216. Alinost all sentences are closed by verbs or words used as such; the principal exception being where interrogative adverbs are used to qualify an entire sentence.

217. When a verb denoting quality or condition, and another denoting action, are used in the same sentence with a common subject, the former precedes the latter; or, in other words, conjugated verbs commonly follow unconjugated rerbs.

218. Verbs in the infinitive usually precede those in the indicatice.

219. Any word used alone, with the terminal ts, in answer to a question, may form a sentence by itself; for it is used as a verb in the sim. ple form, where a personal pronoun of the third person is understood to be in the nominative.

220. In this language, as in other languages, "active transitive verbs govern the objective case". It might be said that all transitive verbs govern the ohjective case, for the existence of a passive form is questionabie. ( $(170)$. When an objective pronoun is followed by the simple form of a transitive verb, the latter may be parsed as in the third person indicative; although, in translating the expression into English, a verb in the passive voice may be used.

221. Other points connected with the syntax of the verb have been refierred to in the discussion of the etymology.

\section{ADJ EC'TIVES.}

22:. There are certain intransitive verbs in the Hidatsa, which are used in the same sense as the adjectives of European languages, and may be translated by them. For the convenience of the Euglish stı. dent, these rerbs will be called adjectives, and described as such. 
223. There are a large number of the adjectives, which we camnot analyze with our present knowledge of the language, and which may be called primitive.

224. Derivative aljectives àre formed from primitive adjectives, from other derivatives, from nouns, adverbs, etc., by forming compound worls, or by the use of suffixes having the force of adverbs.

225. The force of the adjective is modified by the adverbial suffises and also by adverbs used independently, as shown in the following paragraphs.

226. adsi is suffixed to denote an approach to the standard qualit y op possitive degree, as indicated by the simple form of the adjective; thus, from hisi, reil, scarlet, comes hișadsi, of a dull ved color, crimson or purple. ( $(156)$.

227. isid, or ise, is of much the same signification as adsi, but sometimes applied differently; it signities like or resembling. Ex.-From tohi, blue, sky.blue, comes tohisin, of un impure or uncertain blue, bluish; from sip $\mathrm{i}$, black, comes sipisa, resemblin! black, i. e., of a deep color hardly to be distinguished from black. adsi may follow iše to denote a wider vatiation from the standard quality.

228. de is a suffix, which may be translated almost or nearly. Ex.kakilii, round, kakilide, almost round; tsamutsi, straight, tsamutside, almost straight.

229. di increases the signification of the adjective to which it is suffixed; its use is not very extended; it seems to be suffixed only to words of three syllables, ending with i and accented on the penult. Ex.padopi, short, lov-sized, padopidi, very short ; tamulii, minute, taunliidi, very minute.

230. tsạ́ki, good, takes, as an increased or inteusified form, tsạkícti, which may be a compound of tsaki and ictia, great. tsakicti commonly takes the suffix di ; thus, tsakictidi denotes a very high degree of excellence.

231. ksंa denotes that the quality exists excessively, habitually, or continuously. Ex.-išía, bad, išiậkśa, persistently bad. (I 163.)

232. ka'ti, much, true, truly, is a word used independently as an adjective and adverb. As an adverb, it is used to limit the significance of adjectives to the true or standard qualities; as in hisi.ka'ti, true red, bright red, išia-ka'ti, truly bad, unqualifiedly bad.

233. When two nouns are compared together in regard to quality, and either one used as the standard of comparison for the other, the expressions itadotadu and itaokadu are used. The former means at the near side of it, and indicates the less degree; the latter signifies on the far side of it, or beyond it, and indicates the greater degree. These expressions give us more nearly the equivalents of the comparative degree of English than anything else in the Hidatsa.

234. An adjective may be formed of a noun and an adjective. Ex.- 
From mika', grass, and tohisa, bluish, comes mika'tohisa, green (grass. bluish).

235. Some adjectives are compounds of two other adjectices; as, tsidisipi, bay, from tsidi, yellow, and sipi, black.

\section{Numerals.}

236. The Hidatsa system of numeration is strictly decimal ; consequently, there need not be more than ten primitive numeral adjectives.

237. There are, however, not more than eight; these eight are-

$\begin{array}{ll}\text { duétsa (or luetsa), one, } & \text { kíliu, five, } \\ \text { dópa (or nopa), tico, } & \text { akáma (or akawa), six, } \\ \text { dámi (or nawi), three, } & \text { śápua, seven, and } \\ \text { tópa, four, } & \text { pítika, ten. }\end{array}$

238. dópapi, eight, is a compound of dopa, two, and pi (which seems to be the root of pitika); it probably signifies ten less two.*

239. duétsapi, nine, is a compound of duetsa, one, and pi, and seems to mean ten less one.

240. Multiples of ten less than one hundred are named on the same principle as in English; thus we have-
dopápitika (two tens), twenty,
akámaapitika, sixty,
dámiapitika, thirty,
topápitika, forty,
kiliúapitika, fifty, ṡapúapitika, seventy, dópapiapitika, eighty, and duétsapiapitika, ninety.

It will be seen that the first word of each of these compounds, if not ordinarily ending in a, is made to do so in this connection, and that the accent is sometimes removed.

241. The word for one hundred, pitikictía, signifies great ten. The term for one thousand is, pitikictia-ákakodi, - the meaning of akakodi, I know not.

242. Numbers orer ten, but not multiples of ten, are named by the addition of the word alipi (portioned; a part or division), thus:

alipiluétsa, eleven,

alipidópa, ticelve,

alipidámi, thirteen,

alipitópa, fourteen, dopápitika-alipiduétsa, tuenty-one, dopápitika-alipidópa, twenty two, dámiapitika-alipidámi, thirty-tıree, topápitika-alipitópa, forty-four, etc.

243. With the exception of the word for first, itsika, the ordinals are formed by prefixing $\mathrm{i}$ to the cardinal numbers; thus, we have idópa, second, idámi, third, itópa, fourth, etc.

\section{Syntax of Adjectives.}

244. Adjectives usually immediately follow the nouns or pronouns which they qualify.

* Some judicious remarks on this paragraph, and on Par. 239, may be found in a paper On Numerals in American Indian Languages, etc. By J. Hammond 'Irumbull, LL. D. Hartford, 1875. pp. 28, 29. 
245. Qualifying words are often seen used as nouns or pronouns; this is particularly the case with numeral adjectives, and such words as ahu, many, etsa, all, iha, other, kausta, few, etc.

\section{ADVERIBS.}

246. There are adverbs which are apparently primitive; as, tă, not, duk, when, tia, a long time, etc. Many primitive adverbs are used as suffixes, as already shown when describing verbs and adjectives.

247. A large number of adjectives are used as adverbs, without undergoing any change of form. When primitive adjectives are thus used, they appear as primitive adrerbs. Ex.-sua, slow, slowly, hita, fleet, fleetly, atsa, near, tisa, far.

248. Derivative adverbs are formed from nouns, from demonstrative and interrogative pronouns, from adjectives, and from other adverbs.

249. A large number of adverbs of place are formed from nouns by suffixing the prepositions (postpositions), du, lia, ka, koa, and ta ; thus, from dunata, the middle, we have dumatadu, in or through the middle, dumatalia, toward the middle, dumataka, on the middle, dumatakoa, at the middle, and dumatata, facing the middle, or in the direction of the middle.

250. Words formed thus (I 249), might be regarded as merely nouns in the objective, with their governing prepositions; but they are pronounced and used as if belonging to the same class of words as the English adverbs windward and forward. Since every noun in tl:e language is capable of taking one or more of these postpositions, the number of adverbs of this character is very great.

251. From nouns, adverbs of time are formed by suffixing du, duk, and sedn; the first of these means in or during any time, the second in or during future time, the third in or during past time ; thus, from maku, night, we have makudu, during the night, nightly, makuduk, during the coming night, "to-night", mak usedu, during the past night, or "last night"; from oktsia, meaning also night, we have oktsisedu, oktsiadu, and oktsiaduk; from ata, daylight or dawn, we have ataduk, to-morrow, etc.

252. From pronouns, adverbs are formed in much the same way as from nouns; thus, from the demonstrative se, we have siedu, in that time or place, sekoa, at that place, just there, seta, in that direction, and from the interrogative to, we have tóta, whither, tódu and tóka, where, wherein, whereat.

253. When adjectives are used as adverbs, the same suffixes, to modify their force and meaning, are used in the one case as in the other. Adjectives which can denote the mauner of performing the action are those chiefly used as adverbs.

254. Adverbs are formed from numeral adjectives by suffixing to the names of the cardinal numbers $d u$, and the compound preposition tsakoa; thus we have dópadu, at two times, or on two occasions, twice, 
dámidu, thrice, tópadu, four times, and also dópatsakoa, at or in tivo placeś, dámitsakoa, at or in three places, tópatsakoa, in four places, etc.

255. From ordinals, adverbs are formed by the addition of du; thus, ítsikadu, in the first place or order, firstly, idópadu, in the second place or order, secondly, idámidu, thirdly, itópadu, fourthly, etc.

256. In adverbs of time, formed by adding to nouns du, duk, and sedu as indicated in Par. 251, the numeral adjectives are inserted between the noun and the adverbial suffix in the manner and for the purpose here indicated; thus from óktsi or óktsia, night :

oktsíadu, during the night.

oktsidópadu, during two nights.

oktsitópadu, during four nights.

oktsíaduk, during the coming night or to-night.

oktsidópaduk, two nights hence, or during the night after next.

oktsidámiduk, three nights hence.

oktsitópaduk, four nights hence.

oktsísedu, last night, during last night.

oktsidópasiedu, night before last, two nights ago.

oktsitópasiedu, four nights ago.

257. Adverbs formed from nouns are often used as nouns; thus, átaduk, during to-morrow or to-morrow, oktsísedu, during last night, or last night, adéṡedu, during last summer, or last summer.

258. Adverbs are used as predicates to nouns, and in this position, there being no copula, fill the office of iutransitive verbs.

259. "Adverbs qualify verbs, adjectives, and other adverbs", as in other languages.

260. Adverbs usually precede the words which they qualify; but ka'ti, much, or truly, tă, not, ta, only, and the interrogative tok, more commonly follow the worls they qualify.

\section{PREPOSITIONS.}

261. ak ( $(148)$, which is prefixed to verbs, and du, in or during, lia, toward, ka, in, koa, at, ta, in the direction of, facing, which are suffixed to nouns ( $(249)$ to form adverbs, fill more fully the office of prepositions than anything else in the language. They are not, however, used as independent words; and, from the position which they occupy in regard to nouns, would be more properly called postpositions.

262. aka, on; and api, with, are perhaps to be regarded as independent or separate prepositions.

263. There are many adverbs which answer the purpose of prepositions, and may be trauslated by the English prepositions. Adverbs formed from nouns which are the names of place, belong particularly to this class; thus, from míkta, the bottom, comes miktakoa, below, and miktáta, down; from amaho, the interior, amahóka, within or in ; from atási, all out of doors, atásikoa, out. 
264. Prepositions, separate and incorporated, and all adrerbs used as prepositions, follow the nouns which they govern.

265. When incorporated, they may be found suffixed to the nouns which they govern, or prefixed to the verbs which follow; but in either case they come, of course, after the noun.

\section{CONJ UNCTIONS.}

266. There are two words which are possibly simple conjunctions; they are İia, and, also, and duma, but.

267. Other words used in joining words and sentences perform also the duties of adverbs and prepositions, and are properly to be classed as such.

268. Cunjunctions commonly stand between the words, clauses, or sentences which they connect.

\section{INTERJECTIONS.}

269. There are not many words which are purely exclamatory or interjectional; a large number of the words which are used as interjections being rerbs.

270. The following words, however, cannot be well analyzed, and may be regarded as true interjections :

u! oh! expressing pain or astonishment, and commonly preceding a sentence.

ibe! there novo! does that satisfy you? etc.

$\mathrm{ki}$ ! is used in doubt and astonishment.

hidí! used by children when teased; perhaps from the demonstrative pronoun hidi.

hukahé! used by men to express surprise and delight; as when much game is killed at a volley, etc.

tsakak'! an expression of disgust and impatience, may be a derived word. 



\section{HIDATSA DICTIONARY.}





\section{HIDA'TSA DIC'IONARY.}

a.

a

a, n.: a tree, a plant; the entire plant as distinguished from its parts; - used after 'ma' or as a suffix to nouns; as, kohati, corn, koliatia, a stalk of corn.

a, $n$.; a muscle.

a i te, $v$.t.; to strike by throwing; to hit or bruise with a stone or uther missile.

a a ti, $v$.; hurt or bruised by a missile.

i) da [arra], n.; the arıns; the forelegs of quarlrupeds.

ai da, n.; the hair of the head; the locks.

ว̆ d̆̆, a causative prefix to verbs, lenoting that the action is done by the foot, or by heat or tire. (? $14 \pi)$.

a da a du le tí a, n., fir. ada und aluictia; the brachium, the ilper part of the arm.

a dă lı i, $v . i .$, fr. ade and adui; becoming painful.

ă ala lia, $v$. $i$; to be burning; burnt, parched, charred.

ä d̆ lia he, $v$. $t$., $3 \mathrm{~d}$ pers.; to pirch or buru.

ä lă ha ke, v. t., fir. ădălia; to aause to burn; to be burned or parched.

à $\mathbf{l}$ ì lŭ pe, $v$. $t$., fr. ădă and liăpi; to kick; to bark or denude hy kicking.

ă d̆ lié lie, $v$.t.; to seize, take holıl of, cling to;-also ădalielii.

ă lă lié śe, v. t., fr. ăı̆ and liesie; to tear with the foot; to tear with the pars, as a beast.

\section{ăd}

a dă lii se, $v$. $t$.; to be ignorant of.-madaliisets, I don't know, I am ignorant.

a dă lii se ke, $v$. $t$.; to make ignorant; to leave in ignorance.

ă dă lió lii, $v$. t., fir. ădă and liolii; to break with the foot.

a dă lipa ko a, n.; the Mandan Indians.

a dă lipi, n., fr. adu and alipi; a part of anything;-also adạlipi.

a dă lipi ke, $v$. $t$.; to make or be made a portion; to make one thing a part of another.

ă dă liu, $v$. $t$., fir. ălă and liu; to spill with the foot; to upset by kicking;-also alaliue.

ă da í du ti [-ruti], n., fr. ada and iduti; ribbon or braid used in tying up the hair.

al da ka, $v . t ., 2 d$ pers. of ika, to see.

ă da kạ́ da ho [ara-], $n$.; the Arickaree Indians; perhaps from ada, the hair or locks. This name, it is said, was originally applied to the Arickarees from their manner of wearing their bair. The meaning of the last three syllables is now unknown.

ă da kạ p $\ddot{e}, v$. $t$., fr. ădă and kape; to seratch with toe-nails, or with paws, as a dog;-also, aclakạpi.

ă dă kî́ de, $v$. $t$., fir. kide; to push with the foot.

ă dă ki të, $v$. $t$., fir. ădă and kite; to luarn off; to clear by tire. 


\section{ădă}

$\breve{a}$,dă ki ti, $v$.; cleared oft by fire, as a burned prairie.

ă da ku"pa, $v . t$., $2 d$ pers. of iku'pa, to hate.

à dă mi di [-widi], $v, t, f r$. adă and midi; to twist with the foot.

ă dă pa pă du i, $v . i ., f r . \breve{a l d a ~}$ papi ; becoming scorched or sunburnt.

ă dă pa pi [ăla- or ěla-], $v . i$; scorched; sunburnt.

ă dă pá pi de, v. $i$., adj.; almost scorched.

ă dă pa' pi he, $v$. $t$., $3 d$ pers.; to scorch or chap.

ă lă pá pi ke, v.t.; to cause to become scorched or sunburnt ; to expose to sun or fire.

ă dă pe, $v . t$.; to kick.

ă dă sú ki, $v$. $t$., frr. ădă and suki; to erase with the foot.

ă dă tạ lipi, $v$. $i$; ; to snap or crackle in the fire.

ă dă tạ́ hipi he, $v$. $t$; he makes snap by fire.

ă dă tạ lipi ke, v. t.; to cause to snap by fire.

ạ dă tạ́ pi, $v . t$., fr. ăda and tạpi ; to squeeze with the foot; to trample on.

ă dă te, $v$. $i .$, fr. ăda and te; to be bruised under foot; to be trampled to death.

à dă té he, $v$. $t$., $3 d$ pers.; to trample to deatb.

a dă ti, $n ., f r$. adu and ati; a camping-ground; a place marked with the remains of old camps.

ă dă to" ti, v.t., fr. to'ti ; to agitate or shake to and fro with the foot.

á da tsa, n., adv.; a place behind something else; behind.

ă dă tsạ ki, $v$ : $i ., f r$. tsạki; to be serered by fire.

\section{adé}

ă dă tsạ ki he, $v$. $t$; to sever by fire.

á da tsa ko a, adv., fr. adatsa and koa ; behind.

ă dắ tskạ pi, $v$. $t$., fir. ăı̆ and tskapi; to press with the toes; to walk on tiptoes.

ă clă tská, ti, $v$. $t$., fr. ădă and tskati ; to enter or pass through on tiptoes.

a dạ tsku ă du i, $v$. $i$,; becoming progressively moist.

a dạ tsku i [arạtskui], adj.; moist, wet.

a dạ tsku i de, $v$. $i$., fir. adịtskui; almost wet.

a dạ tsku i ke, $v$. $t$.; to wet or moisten ; retted.

a lé, $v . i .$, adj.; to be waru; unpleasantly warm; painful.

a dé, $n$. ; warm weather; summer.

a dé a du i, $v . i$.; same as ada. dui.

a dé dě, adj.; almost painful.

a dé du [-ru], $a d v ., f r$. adé; dıring the summer.

a dé duk [-ruk], $n$. and $a d v ., f r$. ade; next summer; during next summer. - ade dlopa-duk, t w o summers hence. ade-dami-duk [ade-nawi-ruk], three summers hence. ade-topa-duk, four summers hence.

a dé he, $v$. $i$., fr. ade; to be angered; he is angry.

a dé he ke, $v . i$., $f r$. adebe; to make angry.

a dé ke, $v$. $t$., fr. ade; to make warm or painful; changed from a comfurtable to a painfal condi. tiou.

a dé ksia, adj., fr. ade and ksंil; sultry.

a dé se du [-ru], $n$. and $a d v ., f i$. ade and sedu; last summer; dur. ing last summer.-ade-dopa-sedu 


\section{adí}

[ade-nopa-sern], $t w o$ summers ago. ade-topa-sedu, four summers ago.

a dí [ari], $n$. ; a road, a trail.

à di a śá dsi, adj.; poor, desti. tute.

à di a sá dsi ke, $v . t_{\text {. }}$; to imporerish.

ă di i tă du i, $v . i ., f r$. ădiiti and adui; becoming hungry.

à di i ti, v. $i$, allj.; hungrs.-mădiiti, or bădiitits, I am hungry.

à di i ti ke, $v . t$; t to cause to be hungry; to be made hungry.

ai di sa, $n$.; the little raven of the northern plains, probably the Corvus columbianus of Wilson.

ú dř sa i ta pa" his̀, $n$. (See Local Names.)

à dsi, a suffix to verbs and adjec. tives lenoting an approach to the standard. ( 9 156).

á du [aru], prob. fr. du ; a suftix denoting time and place; an adverb of time and place.

a du, a prefix to verbs forming nouns; a part, a place, one of a kind. ( $(\uparrow$ 45-47).

ă du ă dă pa pi, $n$., fr. ădăpapi ; a sunburnt surface.

a du ă du i, $v i ., f r$. adui ; becom. ing bitter.

a du á ka, $n .$, fr. adu and aka; outside part; skin or rind.

a du ak sạ ki, $n .$, fr. adu and akśaki ; a contusion; a contused wound.

a du ai ptse, $n .$, fr. aptse; the edge of a knife.

a du é di, $n ., f r$. adu and edi; ordure.

a du ě ta, $n$.; a sore place, a scar or ulcer.

a du hi dá, $n ., f r$. hilla; new goo:s or articles.

\section{ăidu}

a du hi dú, $n ., f r$. hidu; the skeleton; the bony part of any mem. ber.

a du hó pi, $n$., fr. adlu and hopi; a perforated or excavated place; a hole.

a du hú pa, $n$. See hupa.

a du lia kú pi, n., fri. adu and liakupi ; a groove or crease; a longitudinal depression.

a du liá pi, n.. fr. liạpi ; any place to lie down; a bed, either tem-. porary or permanent.

a du liē pi, n., fr. adu and liepi; a shallow place in a lake or rirer; a shoal.

á du i, a suffix to verbs signifying continnation or progress. ( $(15 \bar{i})$.

ä du i, $v$., adj.; bitter; sour; pungent.

ă du í, $n ., f r$. adu and i; hair ; feathers; the entire plumage ot a bird or pelage of an animal.

a du ic tí a, $n ., f r$. adu and ietia ; the main part, the larger part of auything as distinguished from its smaller parts.

a du i dă lipi, $n$., $f r$. idalipi ; an incised wound, a kuife-cut.

a du i dắ ki san, $n$., $f r$. adu and idakișa; a left-handed person; the left side.

a du i dé, $n ., f r$, adu and ide; speech, language; a word.

ă du i de, $v$. $i$., adj., fr. ădui; almost bitter or sour, as changing milk.

a du i dr tsi, $n$., fr. adu and iditsi ; scent, smell, odor.

a du i dr tsi-i sín a, $n$. (išia, bad); a stench.

a du i dri tsi-tsạ" ki, $n$. (tsạki, good); an agreeable odor.

ă du i ke, $v . t$., fr. ad ui ; to change from sweet to bitter. 
ădı

ă du Ýlìa, adj.; excessively bitter.

a du ptsi, $n$., fr. adu and iptsi; an upright, a perpendicular support, as a chair-leg.

a du i sá mi ke, $n ., f r$. adu and ișamike; young twigs sprouting from a stump.

a du i si, $n ., f r$ adu and isii rind; covering ; exterior;-nearly synonymous with aduaka.

a du i sii n, $n$., fr. isia ; an inferior or rotten portion; - used sometimes as a term of contempt for persons.

a du i tr pe, $n ., f r$. itipe; a bole dug, or a place in any way arranged for a trap.

a du $\mathbf{R}$ a ti, n.; cultivated ground; a field or garden.

a du kati ha, $a d v$.; toward the field.

a du ka ti ka, $a d v$.; in the field; ainong the fields.

a du kạ tí ko a, $a d v$.; at the - field.

a du ké da pi, $n$.; the male of auy species.

a du kí a dě tsi, $n ., f r$. kiadetsi ; a brave, skillful, or enduring person ; a good hunter or warrior ; one intelligent or ingenious.

a du ki a káa ma lre, $n .$, fr. akamake; one-sixth.

a du ki dá-de sa [-nèsa], $n$., fr. kida and desia; a maiden.

a du ki dá-ma tu, $n$.; a woman who is or has been married.

a du ki dá mi he ke, $n ., f r$. kidamiheke; one-third.

a du ki dá mi ke [+-kinawilke], same as adukidamileke.

a du ki dó pa he ke, $n ., f r$. kidopaheke; one-half. adu

a du ki dó pa lie [+-mopa], same as last word.

a du ki du ě tsa pi ke, $n$.; one. ninth.

a du ki du sán, $n ., f r$. adu and kidusa; a place where anything is laid away or put in order.

a du ki du sán ko a, $a d v$., fri adukidusia.

a du ki ká ki, n., fr. kikaki; a seam.

a du ki kî hu a ke, $n$, fr.'kikiliuake; a fifth part.

a du ki sá pu a he ke, n., same as the next word.

a du ki sár pu a ke, $n$., fr. kisiapuake; a seventh part, one-seventls.

a du ki tó pa ke, $n .$, fr. kitopake; a fourth part.

a du má di he, $n$., fr. adu and madihe; prepared food; preparation of food; cooking.

a du má di he a ti, $n ., f r$. adumadihe and ati ; a kitchen.

a du mí ta pa, n., fr. mitapa; falsehoorl, deceit.

a du ó ki pa di, $n$., $f r$. adu and okipadi; young trees, saplings.

a du ó ktsi, $n .$, fr. adu and oktsi ; a shadow.-aduoktsi mahewits, I will make a shadow, $i$. $e$, erect a screen to keep off the suulight.

a du pạ lia du i, $n$., fr. pạliadui ; a blister; a chạfed or blistered part.

a du pạ lii, $n$.; a corner or angle.

a du pạ lii-dár mi [+-nawi], $n . ;$ a triangle.

a du pạ lii-tó pa, $n$. (topa, four); a quadrangle.-adupạlii kiliu, a pentagon.-ad upạhii-ahu, a polygon. 
adtu

a ciu pạ tska, $n ., f i$ adu and pạt:ika; a side; an eren surface; a facet. The compounds of this word and of alupalii are ofteu used srnonsmously; $b$ a t the former commonly refer to flat sur. faces and short solids, the latter to long prismoidal bodies.

a du pạ tska dá mi [-nawi], $n$., fr. adupatska and dawi; a three-sided needle, a glorer's needle.

a diu pạ tska ko a, adv., fr. adupatska; at or on the side.

a cica pa tska tó pa, $n$. (topa, - fivir); any long, four-sided, object, as a hewn log.

a da pí, $n .$, fr. adu and pi, to tattoo or paint; a tattooesl mark on the bolly; tattoning.

a da pr di e, $n ., f i$. pidie; a rufflecl edging.

a dé pó a cla mi [-wi], $n ., f r$. adu and poadami ; a bullet; bul. lets.

a du pó a đla mi-ka di" jta, n. (kadista, small); shot.

a da prí a, n., fir. adu and pua; a swelling.

a diu šă saa, $n .$, fr. adu and sasia; a fork or branch, a bifurcation.

a dar sí pe, $n ., f r$. adu and sipe; a piece of broken ground, a succrssion of steep hills and deep ravines.

a du só ki, $n .$, fir adu and soki; the back of a linife; dull part of any cutting instrument.

a clu śra lia, n., fir adu and suka; a joint; a condyle.

a du tá ka, n., prob. fir. same root as itaka; a graudfather; $a$ granduncle in the male line.

a du tsí di a ma tu", n., lit., it has yellouc spots; a rattlesnake. alip

a du tsó hi, $n ., f r$. tsohi; a poiut; a tapering eud or part.

a du tsíl a, $n$. ; a seed.

a du w, $n ., f i$, adu and $\mathrm{n}$; a wound, more particularls a bullet or arrow wound.

a du ́r é, $n ., f i$, adu and ue; a fire-place.

a du ú e lia, adv., fi. aduue; toward the fire, $i . e$, in the direction of the centre of the lodge, opposite to atutilia.

a du ú $\check{\mathbf{e}} \mathbf{k o} \mathbf{a}$, adv.; at the fireplace.

a du ú è-ü metal); a store.

a du wi ta pa. See adumitapa.

a hi", n.; the "pomme-blanche", or Psoralea esculenta, a plant beariug au edible root, growing wild in Dakota. Recently, the name has been applied to turnips introduced by the whites, and now cultivated by these Indians.

a hi" mi ka, $n ., f r$. abi and mika; the "female pomme-blanche", or Psoralea argophylla.

a hú, adj., adt.; much, mans.ahuts.

a hú ke, $v . t ., f r$. ahu ; to increase, to multipls; increased.

a lió à, $v$. $t$.; to conceal, to hide; also alioe.

á lio ka, $u_{\text {. }}$ t the kidneys.

á lipi, alj., n.; portional; not entire; a part.

a lipgi a liá ma [ $+-w a]$, num. adj.. fi. alipi and akama; sixteen.

a lipi dá mi [+-nawi], adj., $f r$. alipi and dami; thirteen.

a lipí dó pa [+-nopa], adj., fir. alipi and dopa; twelre.

a hipi dó pa pi, adj., $f r$. alipi and dopapi ; eighteen. 


\section{alip}

a lipi du è tsa [+-lu-], num. $a d j ., f r$ alipi and duetsa; nine.

a lipi cla e tsa pi, $n$. $a d j ., f r$, alipi and duetsapi ; niueteen.

a lipi kir liu, adj., fir. alipi and kiliu; fifteen.

a hipi šă pu a, adj., frr. alipi and sapua ; serenteen.

a lipi tó pa, adj., frr. alipi and topa; fourteen.

a liúr a, $v$. $t$., same as alioa.

ak, $v . i .$, prep.; with ; upon ; to be or have with.

ak, a prefix to verbs signifying on or with. ( $(148)$.

á ka, prep., adv.; above; exterior to; surrounding.

á ka, n., prob. fr. last word; rind, peel; same as aduáka.

a kạ hipi, $v$. $t$.; to cross over; to step over.

an ka kg si, $v$. $t$. ; to write in characters, or in Indian symbols; to make a pictorial record, but not to paint for mere ornament.ámakakạsi, I write. ádakakạsi, you write.

ă ka ko di. ( ( 241 ).

a ká ma, num. adj.; six.

a ká ma a pi ti ka, num. adj.; sixty.

a ká ma he, $v . t$., $3 \mathrm{~d}$ pers., $f r$. akama; to make or divide into six.

a ká ma ke, v.t.; to divide into six parts ; divided into six.

á ka pe, $v . t$.; to court, to seek one of the opposite sex.-mia akapets, said of the man.

a kaia ski, $v . t$.; to pull out; to hold between the fingers.

á ka ta, $a d v$., fr. aka; up; upwards.

a ká ta, $n$. ; the palate.

a ka" ta a du hi dú, $n ., f r$.

\section{ăku}

akata and aduhidu; the palatebonès.

a kár wa, num. adj., same as aliáma.

a káa wa a pi ti là, same 18 akamaapitika.

a La za, n., dimin. of a; a ten. don.

$\mathbf{a k}^{\prime}$ (le, $v$. t., comp. of ak and de; to take away with one, to carry something off. - makmadets, I carry away.

alz' hu, $v$. $t$., comp. of ak and hu; to bring, to come and take with.makmahuts, I bring.

a ki, $v . i$. and prefix to verbs; on or with; nearly synonymous with ak, from which it may be derived, or the latter may be a contraction of aki.

á ki lii, $v$. t., fr. aki and elii; to urinate on; to stain or soil in this way.

a ki há hi, $v . i$; to be with; to be taken back with.

a ki ká he, $v$. $t$.; to take back with; to capture and bring home; to take from and bring away.

a hi tsa, v.t.; to overshoot; to miss in throwing.

á ko la a, adv., fr. ak and oka; upon, on top of.

áci é, $v . t$.; to support; to hold in the hand, as a light.

á kisu ĕ, or ak-su-e, $v$. $t$., fir. sue ; to spit upon.

alk' tsi šé, $v$. $t$.; to look through an aperture at something, to look in or out through a window or door, to glance through at.

á lku, $n$.; color; kind, description. akuto? what kind?

ă ku, a relative pronoun, prefixed to -rerbs, forming nouns; it denotes the subject; with transi- 


\section{ăku}

tive verbs the agent, with in. transitice verbs the object of the action; with adjectire rerbs, it denotes something of the color, or kind referred to ; it is prefixed also to nouns used as verbs.

à ku á lia pe, $n ., f r$. aku and akape; a beall, a suitor.

ă ku a ma o" ze, n., fir. amaoze; a farmer.

a ku há tski, n., fro akı and hatski; giants.

à ku hr de, $n .$, fr. aku and hide; a maker, a manufacturer of any. thing.

a ku hr si, $n$., fr. aku and hiši; red eloth; scarlet shrouding.

a Kú lia, adv., apparently from oka and lia; yonder, off; in the direction of the more distaut side.

a kí lii, $n$. ; the human ear; the pinna.-uakulii, my ear.

a ku" lie a du hó pi, n. (adu. hopi, a hole); the meatus auditorius externus.

a ku" lii a du lia kú pi, $n$. (aduliakupi, a groore); fossa of helix of auricle.

ă ku lió ta i jè, $n$., fr. aku and liotaiše ; something of a grayish color; an iron-gray horse.

ă ku i dll tsi tsạ ki, $n ., f r$ iditsitsaki ; scent, material for scenting.

à ku i sí a, n., fr. aku and isia ; a worthless or impecunious per. son ; a person not respected.

a ku kl kse, $n$., fr. aku and kikise; one who fixes, mends or arranges.

ă ku kí ta he, $n$., $f r$. aku and kitahe; a butcher.

ă ku má di he, $n$., $f r$. aku and madihe; a cook.

ă lau má di he a ti, $n$. (ati, a

\section{ăma}

house); a temporary screen or shed erected for cooking purposes; a kitchen.

a ku ma i kú tolki, n., fr. aku and maikutski; one who copies, patterns after, follows an example, or carries out instructions.

ă ku ma i ské, n., fr. aku and maiske; one who commands, directs, or sets an example.

ă ku ma ki kúa a, $n$., fr. kikua; a soldier; the Soldier Band of the Hidatsa; a nember of the Soldier Ban!. This band consists of a number of the bravest and most influential men of the tribe; it enforces laws, administers punishments, has great power, and may discipline even the chief of the tribe. This term is applied also to white soldiers, who, for special distinction, are sometimes called masi-akumaki. kua.

a ku ma tse é tsi, $n ., f r$. aku and matseetsi; men belonging to the class or order of chiefs, men of consequence in the tribe.

a ku pú zi, $n ., f r$ aku and puzi; anything striped or spotted, particularly printed fabrics; calico. See masiiliipuzi.

a ku si' pi sa, $n$., fr. aku and sìpisa; dark blue cloth; black strouding.

à ku tó hi, $n .$, fr. aku and tohi; glass beads used in garnishing. Possibly the beads first introduced by the traders were blue, and bence the name.

ă ma [áma, ábwa, áwa], $n$.; the earth ; earth, clay ; country, land.

a ma ù da lia, $n$., $f r$. ama and adalia ; lignite. 


\section{áma}

á ma á da tsa, $n$., fr. ama and adatsa; the high upland, the open uninhabited prairie.

à kna gí da tsa ko a, $a d v ., f r$. :Imaadatsa; on the nplauds, away from the river-valless.

ă ma a du hia ku" pi, $n ., f r$. ama and aduliakupi; a ravine, an old water-course.

ă ma a du si" pe, $n$., fir. awa and adusipe ; bad-lands".

a ma a lio ka, $n$. fr. ama and alioka; strawberries.

ă ma dă k tsạ ki, $n ., f r$ ama and căkitsạki ; a deep gully.

ă ma dé ta, $n .$, fr. ama and deta; a. bluff; a steep river.bank; high steep hills bordering a valley.

à ma dé ta ko a, $a d v$., fr. amadeta; on or at the bluff.

a ma de ta kn há lii, $n$. (lialii, striped); a bluff of many-colored, stratified rocks.

ă ma de ta ku má ku, $n ., f r$. amadeta, aku, and maku; a high bluff; a bluff forming the edge of a lofty platean, as distinguished from the banks of a river where it passes through its flood-plain.

ă ma de ta ku sí dis̀, $n$. See Local Names.

ă ma de ta ma pá his̀, $n$. See Local Nanies.

a ma dí a, $n ., f r$. ama ; an ordinary low hill, a prairie knoll.

ă ma dí a di da" zi, n., ? fr. amadia ; a ring worm.

ă ma ë, n.; a hoe.

ă ma ẻ a ku tsu" ka, $n$. (tsuka, flat); a spade.

ă ma hă tski, n., fr. ama and hatski; a long ridge; a "di. vide".

ă ma ho, $n$; the inside, the interior.

\section{Anna}

ă ma hó a de, $r$. $i ., f r$ amaho and ade ; to feel internal pain, to be griped.

ă ma hó ka, adv., v. $i$.; within, inside; to be within.-ati amahoka amamakits, I am sitting in the house.

ă nha hó lia ke, $v$. t., fr. ama. hoka; to put into, to place within.

ă naa lia kú pi, $n ., f r$. ama and hakupi ; furrowed land, a tract of land containing one or more ravines; often used synonymously with amaaduliakupi.

ă ma liái mi [-wi], n., fr. ama and liami; a mountain-chain; mountainous country.

ă ma liá mi [-wi], $n$. ; a tribe of Iudians who formerly dwelt in a village of the same name on Knife Rirer. See Ethnography, $\S 11$.

ă ma liáa mi ko a, $a d v$., $f r$. amaliami; at the mountains; said when referring to the Rocky Mountain region.

ă ma liá ti, $v$. and $n$., $f i$. ama and liati ; to shiue ; light ; light proceeding from au original source, not reflected.

a ma liá wi ; alone and in its derivatives 'amaliami' is often thus pronounced.

a ma lió ta, $n ., f i$. ama and liota; salt.

ă ma řc $\mathbf{c}^{\prime} \mathbf{p u}, n .$, fr. ama and icpu; a pointed or conical butte or hill; the point of such a butte; a collection of such buttes.

ă ma ic pu seri sas [or-sase]. See List of Local Names.

ă ma i dạ́ lii see, $n ., f r$ ama and idạliisie; a shorel.

a mak', $v$., imperative of amaki ; sit down, be seated. 


\section{ăma}

ă ma ka, n., prob. fri. awa and ka; a badger. The name may allude to the proximity of his bodly to the earth as be walks, or to his drelling.

a má ka, adv., fr. ama and aka; overground; upon the land.

a má - ka do lipa ka, $n$., $f r$. amaka and dolipaka ; Indiaus; a name of special distinction, used when dolipaka would be ambig. nous.

a má ka moli pa ka, n., same as amakadolipaka.

a má ki, $v$. i., prob. fr. ama und aki ; to sit.

a má ki ke, $v$. $t$; to put sitting: to cause or oblige to sit.

ă ma mạ ki má ka da. See Local Names.

ă ma má ku, n., fr. ama and maku; high ground; a general name for a hill or ridge of any liusl.

ă ma ó ze, $v$. t., fri. ama and oze; to plant.

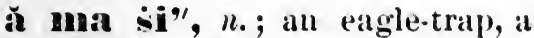
trap in the ground. See Eth. nography, § $\mathbf{3}$, Eagle-Hunting.

ă ma ذi' a, n., frr. ama and išia ; "bad-lands".

ă ma si pe, n., same as amaadusipe.

ă $m a$ si pi sa, $n$. (sipisa, bluck); a dar'k mineral pigwent, obtained by these Iudians from various places in the neighborhood of their village, and used in symbolic writing, decorating robes, etc. Of iate years, the name has beeu also applied to black ink obtained from the whites.

a ma si ta, $n$. (sita, is said to mean cold, ib u I have never heard it so ased but in this ămá

word); the worth, the land north of the Hidatsi country.

ă ma si tá ko a, adv., fr. amasita; northward; at the north; northern ; used also as an adjective and noun.

ă ma si ta" ko a-a ma hár ti, n., literally, northern lights; aurora borealis. See apaliadalia, which is the more common name.

ă ma si tá ko a-ma si, n., lit., achite men of the north; the white inhabitants of Hudsou's Bay Ter. ritory.

ă ma só di sa, $n$. ; the mudswallow.

ă $m a$ ta, adr., fr. ama; turned in the direction of the ground, facing the earth.

a má te, 1st pers. indicutive of ite, to allmire.

a mí ıi, n.; the Missouri River. See Local Names.

ă ma ti", $n .$, fr. ama and ati; an earth-covered lodge; a number of such lorlges; hence, a permanent village of earth-covered lodges.

a már ti a du sa sas. See Lo. cal Names.

à mia ti dá tạ lii [-natạlii], one of the old villages near or on Knife River.

a ma ti lia, $n$. ; another of the Knife River villages.

ă 11 a ti liá mi, same as amaliami ; name of former tribe and village.

a má ti ka za, $n$; the Little Missomi River. See List of Lo. cal Names.

ă má tsa ka" du i, $x$. $i ., f r$. amatsalii; becoming stained with earth. 


\section{ămaí}

ă má tsa ki, adj., fr. ama and tsaki ; stained with earth.

à má tsa lí he, v.t.; he stains with eartl.

ă má tsa ki lie, $v$. $t$.; to stain with earth ; to cause to be soiled with earth; soiled with earth.

ă ma tsí di, $n$., fi. ăma and tsidi; a yellow mineral pigment obtained by the Indians; ochre.

ă ma tsí di o du tsi, $n$. See Local Names.

a ma toúl ka, $n$., $f r$. ama and tsuka; a flat meadow; a bottom.

ă ma í ti, $n ., f r$. ama and uti; the skirt or base of a hill; a foot. hill.

ă ma ú ti lio a, adv. of place, fi. amanti.

a má zi, n.; beans; any leguminous plant.

a ma zi-sí pi sa, $n .$, fr. amazi and sipisa; black beans. The name is also sometimes applied to roasted coffee.

á mpa, $n$.; the neck.

á ntsi. See a'tsi.

al pa, n.; ears, particularly the ears of the lower animals.

ă pă, $n$.; the nose of man and the lower animals; the beak of a bird.

ă" pă a du hó pi, $n ., f r$ ăpă and aduhopi ; nostrils.

$\breve{a}^{\prime \prime}$ pă a du șúu ka, $n ., f r$ ăpă and adusika; the bridge of the nose.

ă pă clá ka, n., dimin. of ăpă; alce of nose.

a pá di, $v . i$; t to sprout and grow, to increase by growth.

a pai di, $n$. ; the Canadian porcupine (Erethizon dorsatum). The animal is common on the Upper Missouri, and its quills are used ápi

for embroidering. This word is also used to designate the quills.

a pá di hi', $n ., f r$. apadi and hi'; porcupine quills.-apadi is the more usual term.

a pá cli ké, $v . t$., fir apadi; to cause to grow; grown.

à Dă hé da pi, n., fr.’apa and hedapi ; the juncture of the nose with the forehead.

a pá lii, $n$. ; the sky; clouds.

a pa lii ăi dă lia, $n$., $f r$, apalii and ădălia; the aurora borealis.

a páa lii a du i lio" tạ ki, $n$. (iliotạki, vhite); white clouds; cirrhus clouds.

a páa lii a du si" pi sa, $n$. (s்ipisa. black); dark, heavy clouds.

a pa hi tạ́ tsi, n. (tạtsi, thick); a sky completely overcast with clouds.

a pa lii tó hi, $n$. (tobi, bluc); the blue sky.

ă pă ic $\mathbf{c}^{\prime} \mathbf{p u ,} n$., fr. ăpă and icpu; the point oî the nose.

a pá ka, $n$. ; mosquito.

ă pă sá ki, $n ., f r$. ăpă and ṡaki, the hand; a pelican (Pelecanus trachyrhynchus). The name alludes either to the shape of the bird's bill or to the use which he makes of it.

ă pă saa kíi pi, $n ., f r$ ăpă and śakupi; a hooked or Roman nose.

à pă tsi túi ki, $n ., f r$ ăgă and tsituki ; a pug-nose.

á pi,prep., etc.; with, to be with.

a pic tí a, $n ., f r$ apa and ictia; a mule.

á pi ka, $a d v ., f r$ api ; together, together with.

á pi ke, $v . t ., f r$. api ; to place together.

a pi sa, $n$. ; the liver. 
apĭ

a pri tsa, $n$. ; sand-bill crane (Grus canadensis).

a pi tsa tó hi, $u_{\text {; }}$, blue heron (Ardea Rerodias).

a pi tska, $n$. ; bristles on lips of Felide, etc.

a pó ka, n.; a head-dress of any kind, a hat or bonnet.

a pó kisa, n.; a pendant jewel; an ear-jewel.

İ pú ti, $n ., f i$. ăpă and uti; the upper lip, the entire upper lip. (See ideta). These Indians seem to regard the upper lip as the "root of the nose".

á pú ti a du lia ku" pi, n.. fr. aputi and aduliakupi; the sulcus of the upper lip.

a r.i, $u$.; a trail; same as adi.

á ru; alone and in its compounds adu is oftea thus pronounced.

a sá di, $v . t$. ; to steal, to take anything illegally or occultly.adi asiadi, "to steal the road", to run away secretls, to abscond.

ä su, $n$.; a string or cord; also a fishing-line; a snare.

á su ka, $\boldsymbol{n}$.; testes.

a" Su ka-ma tú, $n$. ; a stallion.asiuka-deșa, a gelding.

á ta, $n$. ; day ; daylight.-ata-kadista, sometimes said of early in the day--atats, it is day.

á ta dě, n.; almost day, near dar. light.

a tá di, $v . i$; to go out of doors; also to menstruate.

a tá di ke, $r$. $t$.; to put out of doors, or out of the house.

á ta duk [-puk], $n$., $f r$. ata and duk; to-morrow.

á ta duk, $a d v$.; when to-morrow comes.

a tá $\mathbf{~ s e , ~ a d j . : ~ f r . ~ a t a ~ a n d ~ i s ̌ e ̆ ; ~}$ bright as day.

\section{áti}

a tá ka, $n$.; the end or extremity;-perhaps, also, in the end.

ạ tạ ka du, $n$., and adv., fr. ạtạ$\mathrm{ka}$; in or through the end; the terminal portion.

a tạ lia du i, $v$. $i, f r$ atạki and adui; bleaching, gradually whitening.

ạ tạ lia lia, adv., fr. ạtạka ; endwards, towards the end.

a ta ka ko a, adv.; at the end.

a ta ki, arlj.; white; same as iliotạki.

a tạ́ ki ke, $v$.t., fr. atạki; to cause to whiten; whitened, bleached.

á ta ruk, $n$.; to-morrow; same as ataduk.

á tais, $n .$, fr. ati; one's own house; a liome.

a tá ni, $n$. ; out of doors; outside.

a tá zi lia, adv., fr. atazi; toward the outside.

a tai ni lio a, adv.; at the outside; out of the houses.

á tĕ, $n$. ; a father; a father's brothers and male cousins.

a té, $v . i$; to appear, to come in sight.

a té de, $v$. $i$. ; to be almost in sight, nearly appearing.

a té he, $v$. t., fir ate; to make appear, to show.

a té he ka, $v$. t., imper. of ateheke; show it, let us see it.

a té he ke, $v$. $t$.; to cause to appear, to hold up to view, to exbibit.

á tě ka'ti, n., fr. atě and ka'ti ; a true or real father, not a father's brother.

á ti, $n$. ; a house of any kind.

a ti du tri du, $n$.; the roof of an earth.covered lodge.

á ti he, $v . t$., fr. ati; to make a camp. 


\section{ati}

a ti i pki ti, n., fr. ati and ipkiti; the mixture of white earth and water which they use in coating log cabins. Lately this term has been applied to whitewash marle of lime.

á ti ke, $v$. t., fir. ati ; to chauge into a house; to use for a bonse.

a tri si, $n$.; the hole in the top of the lodge to let out the smoke; (recently) a stove-pipe.

a ti sí a, n., prob. fr. ati and isis ; hears, dressed elk or buffalo skin, such as is used in making skin lodges.

a ti tsó hi, $n$.; same as atitsuahe, but less nsed.

a ti tsú a he, $n .$, fr. ati and tsuahe; a skin lodge. The name alludes to its shape.

a ti tsíl ka, n., fr. ati and tsuka ; the side of the fire, a seat in the lodge neither opposite.nor next the door.

ă tsa, prep., adv.; near bs, close to ;-also ătš̌.

$\mathbf{a}^{\prime \prime}$ tsi, n., the mannmce; the udder of an aninal.

a" tsi bi di, n., same as a'tsimidi. a" tsi hi, v., comp. of atsi and hi; to suck.

a" tsi hi ke, $v$. $t$.; to give to suck, to nurse, to suckle.

a" tsi ic per, n., fr. a'tsi and icum; the nipple.

a" tsi mi di, n., fr. a'tsi and midi ; milk.

à tska; adj.; cross, fierce,-as a dog.

ă tskă de, adj.; surly, almost fierce.

ă tskă du i, $v$. $i$; becoming îerce.

ă tska ke, v.t., fr. ătska; to enrage. azi

ă tská kंsa, v. i., adj., fr. ătska and $\mathrm{ksa}$; habitually cross.

ă tská ksa ke, $v$. $t$.; to rencler habitually cross, to sour or:es temper.

á tu, $n$.; the head.

a tú a de, $v$. i., comp. of atu and ade; to have headache.

a tú i tsa ti, $n ., f r$. atu and itsati ; hair-grease.

a tíl ka, n.; the seat opposite the door of a lodge; "at the head".

a tú ti, n., fr. ati and uti; "the bottom of the lodge". In a skiu lodge, this signifies the space betreen the poles and the ground, near where they meet; in an earth-covered lodge, the space between the short uprights, the outer wall, and the ground.

a til ti lia, adv., fr. atuti; in the direction of the bottom of the lodge, away from the fire.

a tín ti ko a, $a d v$.; at or in the bottom of the lodge.

a tíl ti ko a-i" ptsa, $n ., f r$. atutikoa and iptsa; the shorter uprights of an earth-corered lodge, the onter row of supportingposts.

a tíl ti ko a-i" ptsi, same as last word.

a túl ti lio a-mi da", n. Syuon. atutikoaiptsa.

á zi, n.; a river.

á zi, $n$.; a horu.

á zi, n.; a spoon or ladle. The Hidatsa make their spoons of horn; hence, perhaps, the name.

a zi a du śá sa, $n .$, fr. azi and adusasia; a branch or fork of a river.

a zic ti a, $n ., f r$. azi and ictia; the big-horn or Rocks Mountain sheep, Ovis montana. 


\section{ani}

a zi dé hi, $n .$, fr. azi aud delii ; a spoon or ladle made from the horn of the Ovis montana.

a zi liá mi, n., fr. azi and liami; antlers; animals bearing antlers; males of the Cervida.

a zi liá wi, same as aziliami.

a ni ic' pu, n., fir. azi and icpu; the source or head waters of a river.

a zi ic pu ko a, adtu, fir. aziicpu.

a zi ic' pu sa sa, $n ., f i$ aziicpu and saśa; the afflueuts which join a river near its source.

á zi ka na, n., dimin. of azi; a creek or rivulet.

ázi laa zi, n., same us azikaza.

a zi sí pi sa, n., fri. azi and sipisa ; a biack spoon, one made of buffalo.horn.

a zi í e tsa, $n$.; metal spoons, such as are obtained from the whites.

a zi in ti, n., fir. azi and uti; the mouth of a ricer.

\section{b.}

b. Words heard as beginning with the sound of b may be found un. der $\mathrm{m}$.

\section{c.}

c is not an initial sound.

\section{d.}

(I, a common abbreviation of the pronouns da and di.

la [na, la, laa], pers. pron., simple, Il pers.; thou, you, re.

\section{dạli}

da, adv., prefix to rerbs; denotes departure or motion from; as in damakoa, $I$ go aıcay, from makoa, $I$ go.

da' [+ na], probably a form of the last ucord, or of de, to go; suffixed to verbs it makes an imperative form;-go thou! do thou do it!

dă da [nana], $v . i$; to shiver, to tremble.

lái di [na-], $n_{.}$; a party of Indiaus travelling with their effects, a moring camp.

dai dsa, $n$. ; the calf of the leg.

(la hé, $v . t$.; to work, to labor at anything; to make or form.

la he ka" ti [lahekanti], $v$. i., ? from dahe and ka'ti; to be tired.-mallaheka'ti, I am tired.

la he ka" ti he, $v$. $t$., $3 \mathrm{~d}$ pers.; to tire; to fatigue.

da he ka" ti ke, $v$. $t$.; to cause to tire; fatigued.

da he ku ti di ki, $v$. t., fi. diki, to strike-I know not the meaning of the rest of the word; to strike an enemy first, to "count first coup".

dai hu [nahu, lahu], v. i., fr. da and hu; to come away from.damahuts, I come away from. dadahuts [nalahuts], you come away from.

da liăi dě [la-], $v, t$, fir. liădĕ; to shell with the teeth, as corn.

Iạ liạ hi [na-], n.; the elongatted, rertebral, spinous processes between an animal's shoulders; a "hump-rib", a buffalo-hump.

dạ liạ lii má ku, n., fr. dẹliạlii and maku; a high hump, a buffalo-hump.

dạ́ lia mi [-wi], adj., prob. fr. liami; fringed, having long ornamental euds. 


\section{dali}

lar liạ́ pe si, adj.; steep; perpendicular.

da liạ́ pi [la-] v. t., fr. hạpi; to peel otf'; to bark a tree.

la liạ́ pi he si, same as daliạ. pesii.

la lié se, $v$. t., fr. liese; to tear with the teeth.

la lié si, $v ., a d j$. ; torn with teeth. da lié si ke, $v . t$.; to cause to tear with teeth; torn by teeth.

lá lii [ma-], $n$.; a dim shadow or shade; hence also a soul or ghost; seldom used alone. See idalii and dokidalii.

Ia liri lii, $n ., p r o b . f r$. dalii; the reflection of an object as seen on a polished surface; perhaps a hypothetical word. See idaliilii. Ia lii pi, $v$. $t$.; to flay.

Ián lii se, v.t.; to dash or throw away; to dig or shovel.

dă hkí si [na-], n.; a pillow.

tă liki sí si, $n$., fr. dalikisi and isii ; a pillow-case.

daí ho, $n$. ; the lungs.

dá lio ke [na-], ? fr. dalio; a saddle of any kind.-dalioke-hi$d u$, a bone saddle or horn saddle. dahoke-mida, a wooden saddle. See matatsidalioke.

da hó ki, $v$. $t$., fr. lioki; $2 d$ and $3 d$ pers.; to row a boat.-malio. ki, I row.

dạ hipa, $v$. $t$. ; to place the arms around, to enfold in the arms.

dă hipi [nălipi], n.; a pelt of any kiud; a buffalo-robe.

dă hipi ke [nălipike], $u$; the annual religious ceremony of the Hidatsa. See Ethnography, § 22. dă hipri tsi [nălipitsi], $n ., f r$. dălipi and tsi ; a bear.

dă hí tsi-a du a ma" kis̀, $n$. See Local Names. dăk

dă lip̆r tsi-i tsíc pu [na-], $n$, $f r$. dalipitsi and itsicpu; a bear's claw.

dă lip̆ tsi-i tš̆ ti [na-], n., fr. dălipĭtsi and itsiti; a bear's track.

dă hipř tsi-o dă lipi [na-], $n$, $f r$. dalipitsi and odalipi ; a bear. skin.

dă lipi tsó ki [na-], $n$. (tsoki, hard) ; raw-hide, "parflêche".

dă litsi a, adj.; same as daktsia, which is the more common pro. nunciation.

dá liu, $v$. t., fr. liu; to spill, over. set; or topple.

da liú e, v. t.; same as dáliu.

da liún pi, $v$. t., prob. fr. liupi; to drink drs, to drain with the mouth; also, to absorb as a sponge. 3d pers.

dăk [năk], a prefix to verbs and verb-roots, usually indicating that the action is performed by a sudden, forcible impulse. In the 1 st and $2 d$ persons, the ' $d$ ' is sometimes dropped.

dăk' a [năka], same as dăk, from which it may be derived, or the former may be a contraction of dăka.

dá ka, a diminutive suffix.

lá ka, $n$.; the offspring or young of anything. See idaka.

dá ka, $v$. $i$; to remain, to continue in one condition unchanged; to be; to live.

dá ka a du mi di, $n .$, fr. daka, offspring, adu and midi; liquor amnii.

da ka dú tska [-In-], n.; a twin, twins. They are very rare among these Indians.

dă ká he, $v$. t.; to pull toward; to pluck, but not pluck out; to stretch or spread out. 


\section{dalk}

da ká hi se, $v$. $t$.; to hold in the arms.

da kă hi si, held in the arms.

dăk a lió lii, $v$. t., fr. dăka and liolii; to break across with a blow.

dăk a kí ti [năk-], $v$. t., fr. dăka and kiti; to share or remove hair; to clear off' by blows, as these Indians do in removing hair, with a flint or iron scraper, from a skin, preparatory to dressing it.

dăk a mí di [năkawidi], $v$. $i$. and t., fi. dăkia and midi; to twist by sudden force; said if a saddle turns while a horse is running, etc.

dăk a mi di ke, $v$; to cause to turn; turned by sudden force.

dălí a măi tsi [-witsi], $r$. t., fir. dăkil and mitsi; to cut fine by blows, to mince, to chop into small fragments.

dăk a pạki, $r$. $i$; to blossom. clăk a pá ki lie, $v$ t. ; to cause to blossom.

da lạ pe, $r$. t., fr. kịpe; to lacerate with the teeth.

la liá pi, $x$. $t$. See kidakapi, which is the more common form.

dăk a pri lii, $v$. $t$; to float in air or on water; to flap.

dằ a a pï líi he, $v$. $t$.; to float; to allow to tloat. $3 \mathrm{~d}$ pers.

dăk a pĭ lii lie, $v . t$; to cause to float, to make float; floated.

dăk a pú si, $v . i$; to be puffied out, inflated.

dăk a pú si ke, $x$. $t$; to cause to increase in diameter; to puff out.

da kạ ptsi, $v$. i., fr. kạptsi ; to be nicked, to have numerous small notches. lak

da kạ ptsi he, $v$. $t$., $3 d$ pers.; to nick, to cut fine notches, to keep a record or tally by cutting notches.

dăk' a ta, $v$. $t$., fi daka and ta; to smash to pieces by throwing violently or by hitting.

dăk a tá lii, $v$. $i$; to make a noise by stamping, pounding, etc.

dăk a đí, $v . i$; to be stretched out or shaken ont foreibly, as in shaking blankets.

dăk a tí i, same as dăkati.

dăli a ti he, $v$. $t$., $3 d$ pers.; to unfold; unroll : shake out.

dăle a tí lee, $v$; to cause to uuroll; unrolled; unfolded ; shaken out.

dăki a to" ti, $v$ t., fi. dăka and to"ti; to ruftle or shake with force suddenly and briefly ap. plied.

dá lia Isa, adj., $v$, fir. v. $i$. daka, remaining unchanged; alive.

da la a wi di, same as dakamidi. lái ke, a form of daka; to con. tinue, etc.

da" lii [na'ki], n.; a prisoner of war.

dí ki, $v . i$; to squeal as a child.

dá ki [naki], a band or clan in a tribe. In the Hidatsa daki, we hare apparently a modification of the totem system.

da ki dá mi [nakiná wi], $f r$. daki and dami or idami, $i$. $e$, three bands (consolidated) or the third band; one of the Hidatsa clans.

da' hi sii, $n$. ; same as dalikiši.

da lí ti, $v$. $i$., ? fi. kiti ; to close up like a pocket-knife.

da li tó pa [na-], lit., four bands or the fourth bund; the 


\section{dák}

- name of one of the Hidatsa clans, or bands.

dlá ko a [na-], v., fr. da and koa; to go away from, to abscond.damakoa, I go away.

da kó ë [la-], n., a man's friend or comrade; a hypothetical word. See idakoe and madakoe.

lăk sạ ke, $v$. $t$.; to produce a wound by throwing.

lăk sạ ki, $v . i$. ; rounded by a missile.

lăk' $\mathbf{i} \mathbf{i}, v . t$. ; to bundle, to wrap in skins or cloth.

lạk sí pi [nạk-], adv., v.; after in point of time, later, subsequent to.

dăk taí dë, $v . t ., f r$. ktade; to nail with heary blows, to drive a spike.

dăk tsá da ke, $v$. t. and $i$; to slide or cause to slide with sudden, lorcible impulses, as in skating.

dăk tsạ ki, $v$. t., fro dăk and tsa$\mathrm{ki}$; to chop, to cut with heary blows as in chopping wood.

Iăk tsa" ti, $v . t$., fr. dak and tsa$\mathrm{ti}$; to thrust into with force suddenly applied, as in sticking with a spear.

dăk tsi a, $v . i$, adj.; heavy, weighty.

dăak tsi á du i, $v . i$; gradually increasing in weight.

dăl tsi a ke, $v$. $t$.; to make Leary.

dé katsi di, $n ., f r$. daka and tsidi; a name applied to light-colored buffalo-calves.

dăk tsí ke, $v$., $a d j$; t to place in a row; to be in single file; alignied, as the posts of a palisade or the teeth of a comb.

dăk tsú a [nak-], $n_{\text {; }}$ a mink; the Putorius vison.

\section{dám}

dăk tsú ti, $v$. t.; to hit hard; to beat with a stick.

dăk tsú ti, $v$. $t$.; to braid.

dăk ú di, $v$.; to produce a current of air by a sudden motion, as in fauning.

dăk ú dsi, $v$. $i$. and $t$.; to oscillate, to swing; pronounced so much like dakudsi, 2 d pers. of kudsi, that it is difficult to dis. tinguish.

dăk ú liti [năk-], adj.; light, not heavy.

dăk ú hiti hé, $v . t$., $3 \mathrm{~d}$ pers; to make light.

dăk ú liti ke, $v$. $t$.; to make light; reduced in weight.

da" ku pe [na-], n.; a bed-curtain.

dár mi [nawi], num. adj;; three. It is more commonly pronounced nawi, hoth alone and in its derivatives.

dá mi a pi ti ka [+ na-], num. adj.; thirty.

láa mi de [+ na-], adj., $v$.; al. most three, two and a large part of a third.

da mi hé ke $[+$ na-], $v$. $t$.; to make into three, to divide into three; pass. divided into three parts.

dá mî̀ ke, v. t.; same as damiheke.

dé mi tsa ko a, adv.; in three places or directions.

da mir tsi, $v$. $t$., fr. mitsi ; to chew fine.

da mó ki [-wo-], $v . i$; to sink down, to ebb.-kidamoki is the more common form.

dá mu [mawu], adj., etc.; deep; said of water.

dé mu ke [mawu-], v.t.; to deepen ; become deep. 


\section{dăn}

dă nă, same as dădă-midanats, I shiver.

lá pæ̈, $v$.t., fir. da and pe; to eat by tearing, as a dog eats.

da psiú ti, $x, t ., f r \cdot p \dot{s u}$; to shove out of place; to jog the arm.

dă sa, $v . t$; to lacerate with the teeth.

(lái ذi [nasi i], $n$. ; a vame, a proper name; pronounced also dázi.

Lá si e [la-], $x . t$.; to take off with the teeth, as in eating corn from a cob.

la sir pi [la-], v.t., fir. sipi; to untie with the teeth.

dá sku, $v$. t., fir. siku; to extract with the teeth.

dá stè, $v . t$; t to munch, to chew fine; also to pound fine.

dá' ta [+ na-], $n_{\text {. }}$ t the heart. This word is also used figura. tirely, as in English; and rari. ous emotions and feelings are attributed to conditions of the heart, as shown in words which follow.

da' ta dé sa [ma'tanésa], $v$. $i$, adj., fr. da'ta and desa, "heart. less"; giddr, foolish, inconsider. ate.

da' ta dé sa ke, $v, t ., f r$. da'tadesia; to cause to be foolish or inconsiderate.

da' ta dé se, same as da'tadeșa.

da' ta lie pá du i, $v$. $i$, fir. da'. taliepi ; becoming indolent.

da' ta lié pi, $r$. $i$., fi. da'ta and liepi ; to be lazs; indolent.

da' ta lić pi ke, $v$. $t$; to cause to be lazy.

da' ta i si a, $v$. i., fr. da'ta and isia, bad; to be angry; morose, disagreeable; unbapps or sorry.

da' ta i si á du $\mathbf{i}, v$. $i$; becoming angry, etc.

\section{lat}

da' ta i sí a le, $r$. t.; to cause to be worose, angry, etc.; angered.

da tạ́ ki, $v$. $i$; to be hurt, to be in pain.-midataki, I am hurt.

(la tạ pi, $v$. t., fir tapi ; to hold or press between the teeth.

da tai $1 \mathbf{i}, r . t$. ; to squeeze with the teeth.

da' ta tsá ki, $v$. $i$, fi. da'ta and tsaki, goorl; to be bapps, pleasant, agreeable.

La' Ia tsạ kí lie, $r$. $t$.; to make or cause to be happy. .

da' ta tsó ki, $x$. t., fir da'ta and tsoki, hard; tirm, resolute, self. denring.

da' ta tsó ki ke, $v$. t.; to make resolute, etc.

dá ti, brotber-iu-law; a hrpothetical rord. See ida'ti.

da tr pi, $n$. ; a ravine.

da tó: ti, $v$. $t$., fr. to'ti ; to shake to and fro in the mouth, as a cat worries a mouse.

dắ tsa [la-], $v, t ., f r$ tsa ; to bite. la tsái ti [la-], $v$. t., fr. tsati; to stick the teeth into; to hold in the teeth for the purpose of cutting, as these Indiaus do with meat.

lá toi [la-], $v$. i., prob. fi. datsa; dented.

la tsi pi, $v . t_{\text {. }}$; to loosen with the moith ; to lick off with the tongue.

la tskạ pi [la-], v. t., fi. tskạ$\mathrm{pi}$; to pinch with the teeth; to nibble or bite, but not to bite off.

la toliá ti [la-], $v, t, f i$. tskati; to pass or press through a small opening; to squirt or leak.

Ia tskir pi, $v . t$; to pare off, to peel. 
dat

dà tski ti [la-], $v . t ., f r$. tskiti ; to clip, to dock.

da tsó pe, $v$. $t$.; to draw in with the lips, to smack. See kidatsope.

la tsí Li, $v$. $i$; to draw in or suck with the lips, but not to nurse.

lá wi, num. adj., same as dami; more commonly pronounced nawi.

la wi tsi, v. t., same as darnitsi, and more common.

la wó ki. See damoki.

dấ wu, $v$. $i$, same as damu; but more commonly pronounced nawu.

dá zi [nazi], n.; a proper name; same as daṡi.-dazi taká, or nazi taká? what is his name? - manazi, my name.-dadazi, or nanazi, your name.

le, $v . i$; to go, to depart; gone.dets, he is gone, departed.

dé, a suffix to verbs and adjectives, signifying incompleteness, a degree less than the positive; almost, nearly.

dé hi, v., adj.; clear, transparent; white, when referring to the tail of a horse, and some other things.

lé pa, $n$.; certain deformities artificially produced.

dé sa $[+\mathbf{n e s} \mathbf{a}], v . i ., a d v . ;$ no; there is not; there is none, etc.

dé sa ke, $v . t$; to cause to be not, to eause to cease or disappear; pass. disappeared, extinct, cured (as a disease).-kidesake is the more common form.

lé ṡe, same as dềša.

lé ta, $n$. ; a bounclary, edge, or border.

dé ta ko a, ad., fr. deta; at the edge or border.

\section{dík}

dé mi [nezi], $n$. ; the tongue.

dé zi a zisi, $n$. See Local Names. di, $v$. t.; to shoot; to shoot $a t$, whether you kill or not; also to hunt. See kidi.

li, a suffix to adjectives, increasing their force; as in padopidi and kaustadi.

di [ni], pron.; thou; thee; thy. dic' ki [nic-], pron. comp.; thyself.

di da kó e [nilakoe], your friend. See dakoe and idakoe.

di dá' ti, $n$.; your brother-in-law. See ida'ti.

di de, $\}$ v. $i$; to travel, to marcb, di di, ' to walk; also said of the motion of a snake, of swimming. etc.

di di, $n$. ; a travelling party, a party moving or marching; a step, a walk. See matsedidi and paduididi.

di di ki, rour leg. See diki and illiki.

di dř si [ni-], sour son. See disi and idiṡi.

dí do [ni-], p. pron., $2 \mathrm{~d}$ pers., plur.; ye.

dí do ki [ni-], pron., fr. dido; yourselves.

di ha [ni-], $v$. $t$. and auxil., 2d pers., imper.; do thou do it; about the same as da', but more emphatic; added to verbs, it gires one form of the imperative.

di ha, ? aux. verb, suffixed to form the second person, future, indicative of conjugated verbs.

di lio, your body. See lio and ilio.

dǐk, v.t., imperative of diki ; strike.

dr ki, v. t. ; to strike, to whip; to "count coup". 
dik

di ki, a hypothetical word; leg; lower extremity.

dI pi, $v$; to bathe; to be bathing; to bathe one's self.

dir pi lie, $r . t$.; to cause to bathe; to clean by bathing; to bathe another person.

di sá mi [misawi], your anut; fr. liypothetical word sami.

li isi, n.; a son ; probably a bypothetical word. See idisi, didisi, and madisi.

IIr si, $v . i$; to hasten, to hurry, to be fast.

dí sii di si, an imperative form of sidlisi; be thon in haste, hurry up)! hurry thyself.

drr si ke, v.t.; to cause to hurry; hurried.

di ta [ni-], pers. pron., 2d pers. possessive; denotes transfera. ble possession.

di tá du [nitaru], your mother's brother. See itadu.

di ta má e [nitawae], n., $f$ i. dita and una; sour own, your property.

di ta mé tsa [nitawetsa], your brother. See itametsa.

dí toa ki, $v$. , pron.; you alone; you unaided, or by yourself.

dri tsi [nitsi], $v$. $t$.; to massacre. di tú lii $[+$ ni-l, n.; your dress or shirt. See itulii.

ló do pa [loropa], n.; the cheek.

doli [noli], a prefix limiting a noun to the buman species; also pronounced nok and dok.

dohi pá ká [noli-], n.; living human beings; formerly applied only to Indians, but now often nsed to include all races. See amakadolipaka.

dok, same as doli. dót

lok i dáa lia ti [nók-], n., frr. dokidalii and ati ; the village of the dead, the hereafter of the Hidatsa.

dok i dá hi, $n$., fr. dok and idalii; a human shade, a ghost.

dok i da" lii ta i ko mi, n., lit. ghost's whistle; the Equisetum hyemale.

lok i da" lii ta má tsu, $n .$, fi. dokidalii, ita, and matsu, i. e., ghost's cherry; the Virginia creeper; the fruit of the $\mathrm{Vir}$. ginia creeper or Ampelopsis.

dok i da" lii ta ma tsu ai, $n$.; the Virginia creeper, the entire plant.

lok i dá lii ta pa his, $n$. See Local Names.

lok pá ka, n., same as dolipaka. dok te, n., fir. dok and te; a corpse.

dok té o du sa [mokteorusa], n., fi. dokte and odusia; a place of deposit for the dead, a scaffold, grave, or gravesard.

ló pa [+ nopa], num. adj.; two. In compounds, this is sometimes prononnced nupa and dupa.

ló pa he, $v$. $t$., fir. dopa; to make double, to form in two parts.

ló pa he ke, $v . t$; to form into two parts, to divide in two; divided in two.

ló pa ke, same as dopaheke.

dó pa pi [+ no-], num. adj., fi. dopa and pi ; eight.

do pé pi ti ka [+ no-], num. adj., fi. dopa and pitika; twenty. dó pa tsa ko a, $a d v$.; in two places or directions.

ló ta [lota], n., adv.; near to; the near side; neighborhood or proximity. 


\section{dót}

ló ta du [-Ro], adt., u., fir dota; the near sile; at or in the near side. See itadotadu.

dé ta ha [10-], adv., fr. dota ; in this direction; denoting motion toward the speaker.

ló ta ko a, adv., fir. dota; in the neighborhood of the speaker; at a place nearer to the speaker than some object named; also, inferior to.

Ió ti [10-], $n$. ; the throat.

lo tic tí a, $n ., f r$. doti and ictia; bronchocele,-a disorder not uncommon in the village at Fort Berthold.

d ad, a hypothetical word. See idu. lu [1u], a prefix to verb-roots, denoting general causation, that the action is done in some way not specified. Same as Dakota ' $\mathrm{yu}$ '.

du [ru], prep.; in, during, at that time or place. Suffixed to nouns, it forms adverbs of time and place. Suffixed to pronouns, it forms words which may be con. sidered as pronouns or adrerbs.

du é tsa [+ lu-], num.adj.; one. du é tsa ke, $v$. $t$.; to cause to be one; united.

lua é tsa pi [+ lu-], num. adj., fr. duetsa and pi ; nine.

du é tsa pi ke, $v$. $t$., fr. duetsapi ; to divide into nine parts.

du é tsa ta, adj.; only one.

llu tsa ti, $v . i ., a d j$; one here and there; to be a scattered few. Iri ha, $v$., imper. and $2 d$ pers. in. dic. of duhe; lift.-diduha, lift thyself, $i . e$, arise (from sitting).

dis he, $v$. $t$. ; to lift, to raise up.

lúi hi, $v$.; lifted, raised; aroused. drí hi ke, $v$. $t$; to cause to arise; to assist in rising or raising.

\section{dum}

Irí lia, $v$. t.; to spread, as bed. ding.-kidulia is the unore com. mon form.

Iu liá dé, $v$. $t$.; to collect by dragging; to rake.

du hiă de, $v$. $t$.; to shell, as corn. du lié nii, $v$. $i$; said of the settling down of a river, the abating of a flood.

du lié se, $v . t ., f r$. hesie; to tear in any way, to tear such articles as cloth or paper.

du lié wi, same as duliemi.

du lió hii, $v$. t., fr. holii; to break across by any means; to break by bending, as in breaking a stick.

diu lió lii ke, $v$. $t$.; to cause to be broken; broken.

du lió ki, $v$. t., fr. lioki; to sepa. rate by dragging, as in comb. ing.

dú lipi, $v$. t.; to take down something that is hanging on a nail or peg.

duk [ruk], an adverb of future time; when-will. It is also used to denote uncertainty or condition with regard to future erents. It is suffixed.

lu kạ pi, $v$. t., $f r$. kạpi ; to lacer. ate by ans meaus; to wound by tearing.

Ír ki di, $x$. t., fr. kidi; to pull a skin back and forth across a rope, as is done in dressing hides.

Iu ki $1 \mathbf{i}, v$. t.,fr. kiti ; to clear off by plucking, to pluck clean.

du kín ti, $v$. t.; to pluck.

du mă hii ta, $v$. $i ., a d v$.; back and forth, going from side to side, changing direction rapidly. lu mă lii'ta ti di e, $v$.; to run back and forth. 


\section{dum}

slu má ta [ru-, nu-], $n$. ; middle, the middle of anything.

du má ta du [-1)u], adv., n.; in or through the middle; the mid. dle part of anything.

odu má ta lia, $a d v$; towarl the millule.

du má ta ko a, $a d v$.; at the midảle.

du má ta ta, $a d v$.; facing the middle, directed towarl the midl. dle.

du mán tí tstí, $v$., fr. dumata and itski; tied in the middle; cut or strangled in the midlle.

du mí di, $v$. $t$., fr. midi ; to twist or twill in any way.

dú mi lia [-wi-], v., adv.; to turn or point out of a straight line, in an oblique direction; said of a white man's track-toes ontward, of the track of a man lost in a storm, ete.

du mú dsi [duwudsi], $v . t$., $f r$. mudsi; to roll up; nearly the same as pamudsi.

Ilí pi, v. $t$.; to break off a portion. alu pú pi, adj; ; capable of stretch. ing and recoiling, elastic.

dú șe [11-, lu-], v. t.; to lay down, to release, to deposit.dusa and dusia-diha are impera. tive forms.

du sir pi, v.t.; to untie; to open like a sack by pulling , the edges apart.

dú ske [ru-], v.t.; to open, as a door or the lid of a box.- dusika, imperative.-dusiki, opened.

dú sku, $v . t$.; to place an eril charm on, to bewitch.

d ı sún ki [ru-], v. t., fr. ṡuki; to erase, to clean by rubbing; to wash as the face, but not as clothing.

\section{dut}

du tá, $v$. $i, f_{i}$. ta; to erack; to go to pieces in any was.

dú ta [nuta, luta], $n$. ; a rib ; ribs.

Iu tá he, $v$. $t$., $f r$. duta ; to cause to burst, or fly to pieces.

du tạ pi [pu], v.t., fr. tạpi ; to squeeze; to hold and press, as in shaking hands; to squeeze in ans way.

du tá ti, frotati; to poke or punch; to press with the fingertip.

ló ti [nuti], v. t.; to chew; to eat, to partike of solid food.duti is the form of the $2 d$ and $3 d$ persons;-muti; of the 1 st person. See If 196 .

dú ti, $v . t$.; to bind, to confine. In this word, the initial $d$ (or r) is retained thronghout its conje gation (1st var. I 195), which distinguishes it from luti, to eat; but in the $3 d$ person and in the infinitive, these two verbs are homonsmous.

du tr ksa, $v . t$. ; to eat constantIs, habitually.

du tó' ti, v. t., fr. to'ti; to shake as in casting pepper; to dredge or sprinkle.

dú tsa, simple imperative of dutsi, take it, get it.

Ju tsé ala, v. t., fr. tsada; to slide or slip in any was.

lu tsạ ki, v. .t., fr. tsạki; to dissever withont entting or burning; to pull apart.

lu tsá ki de, $v$., adj.; almost dissevered, torn so as to be held only by a thread.

lu tsá, ti, v. t., fr. tsa'ti ; to stick, thrust through, impale; hold in readiness for cutting by sticking. 


\section{dút}

dís tsĕ, $v . t$; to take hold of; to obtain ; to lift.

dú tgi [ru-], $v$; taken; procured. du to pir, v. t.; to untie.

Iu tsi si, $v$. $i$; to spring back, as someihing bent and released.kidutsisi is the more common form.

du tsir ti, v. t.; to tear asunder; to tear down, to raze a building. dú tska, $v$. or adj.; twin. See dakadutska.

du tokna pi, v. i., fr. tskạpi ; to pineh with an instrument.

In ts láa ti, v. t., fr. tskati; to squerze, force, or pass through, by any means.

du tski pi, $v$. $t$.; to milk a cow. This word seems to be from same croot as datskipi, but the connection is not obvious.

du tolki si, $v$. $t$.; to wash ; said of washing clothing.

du tski ti, v.t., fr. tskiti ; to encircle the bods, neck, limbs, or any object, with something which presses closely; to tie a string tightly around, to strangle, to kill by hanging, to tie a sack in the middle, etc.

du tskú pi, $v$. $t ., f r$. tskupi ; to bend, to double by pressure or otherwise; to bend a stick for setting a spring-trap.

du tsú ki, v. t.; to knead the ab. domen (kneading the abdomen is a common remedy for numerons complaints with this people); to engirdle.

du tún' ti, $v$. $t$.; same as duto'ti. du wá lii ta, $v$. $i$; same as dumaliita.

du wi di, v. t. ; same as dumidi.

\section{hah}

\section{c.}

$\overline{\mathbf{e}}, a d v . ;$ yes.

e, $v$.t.; to keep, to retain.

e de le, $v$. ; to bear, to lay.

c di, $n$.; the abdomen.

é $\mathbf{d i}, v . t . ;$ to defecate.

e lic' ti, v. t., frr. edi, with the suffix ti; denoting desire or readiness.

e die tí a, $v$. $i .$, fr. edi and ictia ; to be pregnant.

é di de, comp. $v$., fr. edi and de.

č du i, adj.; same as adui; pun. gent, bitter.

e lii, $v$. ; to urinate.

e liic' ti, $v$. $i ., f r$. elii and ti ; denoting desire or readiness.

e ke, v.t.; to know; to understand; to recognize.

é ke ta', v. t., negative of eke; to know not.-emaketăts is the trine equivalent of $I$ don't know, but madálisets, I am ignorant, is more commonly used.

é Iu i, same as edui and adui; this pronunciation is quite common.

$\breve{\mathbf{e}} \mathbf{p e}, v . t . ;$ to grind or triturate; same as pě.

é ri, n.; same as edi.

é Isa, $n ., a d j$; all, the aggregate of a number of individuals; not ordinarily applied to the whole of one thing. See liakahéta.

é tsa de, adj.; almost all.

\section{h.}

ha, $v$. and suffix to rerbs, $2 d$ pers. of he; rou do; you make.

ha hé tĕ, $v$. $t$.; to divorce.-haheta, $2 d$ pers. 


\section{hah}

ha hé ti ; divorced.

hă lipi, $v$. $i$; to sneeze.

Ită lipic ti, v. $i ., f r$. balipi ; to have a desire to sneeze, to be reanly or abont to sneeze.

hă lipi ke, v.t.; to cause to slles"ze, to prodnce sneezing.

ha kă' Ia [haliănta], $2 d$ pers. and imper. of haka'ti ; wait, halt!

ha kăh ti, $v$. $i$.; to stop, cease, leave ott, halt.

hat liă' ti he, $v$. t.; to stop or arrest.

ha lăa ti ke, $v . t$; to cause to stopl; stopped.-bakitti and its derivatives are often used with li is the first letter. See liakati.

há kạ tsi, $v$. $t$; t to butcher, to cut up meat.

há lie, $v . t$. ; to gather and hold up with the hands, as the edge of a robe or skirt is held in wading.

há Ino lia, adv.; above, overhearl, but not in contact with; nearly the same as akoka.

há mi [hawi], $v . i$; to sleep.

ha mic' ti, $v$. $i$., fr. hami and $\mathrm{ti}$; to be sleepy.

há mi de, $v$. i.; almost asleep, lozing.

ha mr ksa, $v$. $i$.; to sleep habitnally and excessively.

há o, interj., adv.; a word used to denote approbation, gratification, agreement, assent, or greeting. It is commorr to many Indian languages. It is usually written "how" by travellers, and is often pronounced by Indians the same as the English word hor. It is difficult to determine the best mode of spelling. Mr. Riggs in his Dakota Dictionary writes it hao and ho, both of he

which forms are used here also, although the Hidatsa rarely say bo.

ha pá, adj.; cold, chilly; refers to the sensation is experienced by living animals.

ha pá ke, $v$. ; to make cold; changed from warm to cold, chilled.

ha' pé sa, v. $i$., adj.; dark, devoid of light.

ha' pé sa de, adj., n.; almost dark; twilight.

ha' pé sa du i, $v$. $i$.; darken: ing.

ha' pé sa lie, v. t.; to darken; darkened.

ha si si, $v$. $i$; to feel a stinging or smarting sensation.

ha si si he, $v$. $t$.; to sting, to sinart.

ha si si lie, v.t.; to cause to smat; rendered sharply pain. ful.

há tsa, $v . t ., f r$. tsa ; to clean or separate by scraping.

hái tsa ke ki, $v$. $i$; to hiccough.

há tsa ke kic ti, $v$. $i$, fr. hatsakeki ; to hare a desire to hiccough, to be about to hiccough, to be hiccoughing and likely to continue.

ha tsí te, $v$. $t$.; to cook by roasting or baking.

ha tskái du i, $v . i$, fr. hatska; lengthening gradually.

há tski, adj.; long.

há tslii de, adj.; almost long, nearly lo:ig enough.

há tski ke, $v$. $t$.; to make long; lengthened.

hái tski ks̀a, v., adj.; continuously or excessively long.

há wi, $v$. $i$; same as hami.

he, $v . t$; to make; to prepare. 


\section{hé}

he, an auxiliary verb or suffix to verbs, forming transitive from intransitive verbs; $3 d$ pers.; signifies to make or cause. (I 160).

hé da pi, $n$. ; the waist.

hé duts, same as heide, and apparently a contraction.

hé i de, $v$. $i$., or sentence, $f r$. ide; "so he says"; "that is what he says"; said when quoting or repeating, and ordinarily used with the terminal ts; thus, heidets.

hi, v. t.; to draw into the mouth, as in smoking or drinking; an irregular verb. ( $(2: 0)$.

hi, $v$.; to touch, to come in con. tact with.

hi [or i], $n$. ; a sharp point; the point of an instrument; commonly suffixed.

hi', $n$. ; a common name for dermal appendages-hair, feathers, bristles, etc. ; commonly used as a suffix, or terminal part of a compound noun.

hi, pers. pron.. $3 d$ pers., singular.

hi dá, $v$., adj., ? from hr̆di ; new, recently made.

hi dá ka tsa, $v$. i., fr. daka; it lives; it continues.

hí da mi [-wi],$v . i$, imperf. $3 d$ pers., same as hami; he sleeps.

hí da mi de, $v$. $i$., fr . hidami; he dozes.

hi dá tsa, $n$; said to mean " willows"; the name of one of the old villages of this tribe on the Knife River, and the present name of the entire tribe.

hil di, $v \cdot t$.; to make; to form.

hi di', interj.; let me alone! there now! Used mostly by children when being teased.

\section{híd}

hí di, dem. pron.; this; is nsed for person, place, and time.hidimape; this day, to-day.

hí di ka, $a d j ., f r$. hidi and ka ; in this compass, this amount, so much.- - hídika or bídikats is said when exhibiting a quantity, or giving an idea of quantity by signs.

hí di ko a, $a d v ., f r$. hidi and koa; at this place, here.

hí di mi, $a d j$., fr. hidi; this many, so many. It is used in much the same way as hidika, but refers to number instead of quantity. It answers the question 'túami?' how many?

hí di šé, $a d v ., f r$. hidi and ise; thus, in this manner.

hí di ta, $a d v ., f r$. hidi; in this way or direction; this part.

hi di wi or hídiwits, common modes of pronouncing hidimi. hidliwits is the terminal form.

hí do, pers. pron., 3d pers., plural. hi dó, dem. pron.; that, that persoll or place.

hi dó, $a d v$.; in that place, there. hi do ka, $a d v$. fr. hidó; in that place; by that was; therein.

hí do ki, comp. pers. pron., 3d person, plur., fr. hido; them. selves.

hi du, $n$. ; a mother.

hi dí, $n$.; bone.

hi du" a du pu púu lii, $n$. ; carti. lage.

hi dún i mạk i a, $n ., f r$. hidu and imakia ; bones used in gaming. The name has been recent. ly applied to dominoes.

hi dú ka, advo, same as hidoka; also pronouncedl hílluka.

hí du si di, $n$. ; the Assinneboine Indians. 


\section{hík}

hi ke, $v . t_{.,} f r$. hi, to drink; to cause to drink, as in watering a horse.

hr sái dsi, $v$. $i$., adj., fr. hỉsi; of a dull or doubtful red color, red but not scarlet, reddish.

hí sai dsi ke, $v$. $t$.; to make of a redilish color'; to dye reddish.

hĭ ṡá du i, $v . i$; reddening, becoming red.

hY si, adj.; red ; bright red, scarlet.-Lřsi.délii.hisis, a light transparent red._hrsi-ámabu-liota, pink.

hî si de, $v$. $i$., adj., fr. hịisii; alınost rell; said of an iron or stone that is being heated.

hr si he, $v . t$.; to redden.

hI si lie, $v$. $t$; to dye red; to make red.

hl si ke, $v$.; reddened; dyed red.

hř ذi săi du i, $v i$., fr. his̉ise; assuming a reddish tinge.

hř sir se, $a d j ., v, i ., f r$. hrši and ls̉e; haviug a reddish tinge; said of northern lights, the morning sky, ete.;-also hršišsi.

hí si si ke, $v$. $t$.; to cause to assume a reddish tinge.

hř súu a, n.; mint, Mentha cana. densis.

hi ta, $a$ llj.; fast, fleet; said of a gool rumuer; used also adverb. ially.

hi tá du i, $v . i$; ; becoming fleet, increasing in speed.

hi ta ha, $a d v$.; fleetle, rapidly; a more proper adverbial form than hita.

hi ta ke, $v$. $t$; t to make fleet, to accelerate motion.

ho; the word hao (which see) is sometimes thus pronounced.

hó i ke or hówike, $v$.; to hum

\section{huá}

a child to sleep; to drone a lullabr.

hó pa, $a d v$. ; slowis; tediousls, wearily.

ho pá, $v$. $i$., adj.; to be mysterious; sacred; to hare curative powers; to possess a charm; incomprebensible; spiritual. Same as Dakota, wakan, but signifies also the power of curing dis. eases.

ho pá di, n., fr. hopá; msstery; medicine; incomprehensible power or inflnence, etc.

hó' pa du i, $v$. $i ., f r$. ho'pi and adui; becoming more and more perforated in different, piaces, as a target at which marksmen are shooting.

hó pa ke, v. t., fr. bópa; to make slow, to canse to be slow.

ho pạ se, v.t.; to scare greatly, to terrify.-hopasirts, territied.

ho pá ti, n., prob. fr. hupa; ; corn in the ear; roasting ears.

ho pá ti si, $n ., f r$. hopati and İsi ; corn-husks.

hó' pi or hópi, $v$. i., adj.; bored, perforated; excavated.

hó' pi de, adj.; almost perforated, bored nearly through.

hó' pi ke, $v$. $t$.; to perforate; bored through; supplied with au excava tion or opening.

hu, $v$. $i$.; to come.-hu', imperative.

hu, n.; a mother. This word is said to be of amaliami origin.

hú a, $v$. $i$.; to cough.

hú a ke, v.t.; to canse to cough.

hu á kśa, $v$. $i$.; to cough habitu. ally or continuously, as with a bad coll.

hu a $1 \mathbf{i}, v$. $i$; to have a desire to cough ; to be about to cough. 


\section{húd}

hú di se du [huriseru], n., $a d v$. ; yesterday. See sedu.

hú duk, $a d v ., f i$. hu and duk; when it comes to pass, at a future time specified.

hu ka hé ! interj.; hallo! etc.

hú pa, $n$.; soup.

hú pa, $n$. ; moccasins. See itápa.

hú pa, n.; a stem or handle; a corn-cob; a jipe-stem, etc.

hu pa a ku i kú tski, $n ., f r$. aku and, ikutski; a "measuring worm".

hu té, $n$. ; a screech.owl.

hú tsi, $n$. ; wind.

\section{h.}

lia, prep.; toward, in the direction of; suffixed to nouns, it forms arlverbs, which qualify verbs denoting motion.

lia, adj.; coarse, rough, scaly, etc ; used only as a factor of compound words.

lia bú a, same as lianua.

liă da liá du i, $v$. $i$.; growing lean.

kiă da lii, arjj.; lean.

hă da lii ke, v. $t$; to cause to be lean ; to starve; starved, reduced to a condition of leanness.

liăi da lii ks̉a, adj., v.; habitually lean; emaciated.

liă da hí ksia ke, r. $t$.; to cause to be emaciated.

liă de, verbal-root; shell, as corn.

lia dé, $n$. ; rain.

lia dé, $v$. ; to rain._liadets, it rains.

lia di e, $v$.; to ruin; same as liade.

há lia, $v$. $i$, fr. lia ; very rougb, prickly, echiuate.

\section{liák}

lia lián du i, $v . i$; becoming very rough.

liá lia dsi, $v . i$; roughish, har'ing the appearance of being rough.

lia lián tu a, $n$. (Dakiota, lialiatonway); the Chippeway In. dians.

hà liá tu a-ma si, $n$. (maši, vhites); the Red River halfbreeds.

liá lii, v., adj.; striped, marked with parallel bands or lines.

liá lii he, $v$ : $t$., $3 d$ pers.; to stripe, to mårk owith parallel bands.

lián lii ke, v.t.; to stripe, to cause to be striped.

ha lír a, $v . i ., a d j$; to be set closely together; thickly studded.

lia liú a ke, $v . t$; to cause to set closely together, to compel a large number of persons or things to occupy a swall surface, to plant closely, to pitch camp with the lodges close together.

lia liú a kìa, adj.; continuously or constantly close, or thickly set.

liă ka, $v . i$; to be rocking, oscillating, shaken, or agitated.

liá ka, $v . i$; to itch; to be afflicted with itching sores, as in small-pox.

liá la du i, $v$. $i$; becoming itchy or more itchy.

liă ka he, v. t., fr. hăka; to rock, shake, or agitate.

liă ka lać ta, $y ., n ., a d j$; whole, entire; the entire of one thing.

liă ka hé ta de, adj.; almost entire.

liă ka hé ta ke, $v$. $t$.; to make whole or entire; (x)mpleted.

liá ka ke, v. t., fr. liaka; to make 


\section{liak}

itchy, to produce an itchy sensation or an itching sore.

lia ka' ta, same as hakata. In the derivatives of this word also, li is often substituted for the initial h.

lia líu pi, v. i., adj.; hollowed longitudinally, having a crease or furrow.

lia kí pi he, v. t.; to make a crease or furrow.

lia líu pi ke, $v$. $t$.; to furrow, to mark with creases or grooves; grooved.

liá ma dsi [-wa-], v. $i ., a d j ., f r$. liami; having a diverging appearance.

liá ma du i [-wa-], v. i., fr. lia$\mathrm{mi}$; becoming progressively more branched, forked. or diperging.

liá mi [-wi], v. i., adj.; to be forked; scattering or diverging.

liá mi lie, v. t., fr. liami ; to cause to diverge or scatter, as in toss. ing the hair.

lia múr a [-bu-], $v$. i., fr. mua; to malie a rough noise, to rattle.

lián pa du i, $v$. $i$, fr r. liapi and adui; becoming thinuer; wearing thin.

liạ pạ tá du i, $v$. $i ., f r$ liạpạti; becoming satiated.

liạ pạ ti, $v$. $i$; to have a feeling of satiety, to have hunger or thirst fully satisfied, to be satisfied or satiated in any respect.

liạ pạ ti de, almost satistied.

lia pá ti he, v. t. ; to satisfy.

lia par ti lie, v.t.; to satisty ; to canse to be satisfied, to supply with food sufficient for sitisfaction; satisfied.

lia pạ ti ksan, $v . i .$, adj.; habitually satiated; gorged, satisfied to disgust.

\section{liém}

liă pe, , verbal root; denude, reliă pi, f move surface, peel.

liá pi, $v . i .$, adj.; tḥin, as paper or tinely dressed skin.

liạ pi, $v . i$. ; to lie down.-liạp, imperative.

Fiá pi, $v . i$; to be lost.

liạ pi hé, v. t.; to lose; lie loses or lost ; they lose. (9/ 20?).

lia pi hé lie, $v$. $t$; to cause to lose.

liạ́ pi hé lksa, $v$; to lose frequently or excessively; to bo careless of things; to be in the habit of losing.

liá pi lic, v. t., fr. hapi ; to make thin, to wear thin, to cause to be thin.

liá pi ke, $m$ a de thiu, worn thiil.

liạ pi lie, $v$. t., fr. happi; to cause to be lost, to lose.

liá pi lasa, $v$. $i$; excessively thin; constantly thin.

liă ta tạ ka, yalv.; rapilly, liă ta tạ ka ha, in frequentand rapid succession.

liă ta tạ ká du i, $v$. $i$., fr. hătatạki; becoming gradually accelerated in motion.

liă ta tạ lii, v. i., adj.; to be rapil, to move rapidly.

liăi ta tạ líi lie, v.t.; to make rapid, to accelerate motion.

liá ti, verbal root; to brighten or lighten; hence, amaliati and oliati.

liá wi, same as liami.

lic, adj, probably a contraction of liie; oll.

lié mi [-wi], v. $i .$, adj.; lonesome. lié nai-ke [-wi-], $v . t$; to make lonesome.

lié mi lisa, $v$. $i$; continually lonesome; melancholy. 


\section{liép}

lićpa du i, $v$. $i$, fr. liepi ; becoming more shallow.

hé pi, $v . i .$, gdj.; shallow ; applied to water, etc.

lié pi de, $v$. $i$; almost shallow.

hé pi ke, v.t.; to make shallow, to bail ont or drain out.

hé pi tac, made shaliow, drained or evaporated to shallowness.

lic pi kia, $v . i$; very shallow; continually shallow.

lié pi kisaa ke, v. t., fr. liepiks̀a.

lie se, verbal root; tear through, separate.

lié wi, a common pronunciation of liemi, either when used alone or in its derivatives.

hi di a, $v$. $i$. ; to experience an itching sensation; to feel other abnormal or peculiar sensations.

bi di a ac, v. t.; to make itehy or sensitive.

hì di á lisa, $v$. i. ; persistently or habitually itchy or sensitive.

hii é, $a d j$. ; old, advanced in age; decrepit as if old ; said of organized beings.

lii é lie, v.t.; to cause to be old or decrepit.

lii é Lisa, adj., v.; superannuated.

hí pa du i, $v$. $i$., fr. liípi ; becoming wriukled, as a person ad. vancing in age.

hi pe, verbal root; skin, flay.

lio, hypothetical word ; the body ; the trunk; the entire body. See ilio, dilio, and malio.

lió lii, verbal root; break across, break by bending.

lio lio i, $v . i$; to experience the peculiar weak or painful feeling in the eyes resulting from deferred sleep.-mista liolioits, my eyes are sleepy. i

lió ka, n.; a skunk, Mephitis mephitica.

lió ka di ti, v. t.; to close up by tying.

lió ki, verbal root, denotes the pulling of a hard instrument through something that jields, as in pulling a comb through the hair, an oar through water.

lio pạ́ se, $v$. t., same as Lopạseliopạse is the more common pronunciation.

lio pá sí ritied.

lio pá si lae, $v$.t.; to cause to be scared.

lió ta, adj.; gras ; whitish-gray.

lió ti s̀a, $f a d j ., f r$. Lota and išé;

lió ti šĕ, f grayish, i r o n.gray ; said in describing horses.

liu, verbal root; upset, spill, throw down.

liú a lia, n., ? hypothetical; the knees. See ilinalia.

lirí e, $v$. $t$. and $i$.; to upset; to topple over, as a stick set upright.

liú e de, $v$. $i ., f r$. liue and de; to be almost falling; to stumble.

liú liu i, same as liolioi.

liu pi, verbal root; drain dry; drink, absorb. See daliupi.

liu ti, verbal root, or ? modified fr. liu; to be in a condition to fall, placed insecurely.

lír'ti, $n$. ; gloves; mittens.

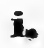

i, $n$. ; point, edge ; tooth ; same as bi.

i', $n_{\text {. }}$; hair of animals; prob. fr. hi'.

i or i $\mathbf{i}^{*}, n_{.}$; the mouth. 
i

i, pers.pron., incorporated,3d pers., masc., fem., and neut., sing. and plur., objective and possessive. In the objective, it may denote the combined agent and object of a reflexire verb. In the possessive, it usually denotes nontransferable possession.

i, a prefix forming, with verbs, nouns of the material or instrument. Prefixed to cardinal numbers, it forms ordinals.

i a lia lia, $v . t$.; to encircle or surround; surromnding it.-aliahia is perhaps the simple word.

í a lio a, v., reflex of alioa ; also, iallioe.

i a ka, $n$.; a man's elder brother.miaka, my elder brother. diaka, your elder brother.

i a pa ti, $n$.; a stopple of any kind ; a cork.

ic kă, n.; a star.

ic kă dá mi [-nawi], no, fr. icka and dami; the Belt of Orion.

ic lăa dé lii, $n$., fr. icka and delii ; Sirius.

ic Kă lia liú a, $n ., f r$. icka and lialiua ; the Pleiades.

ic kă ic tí a, $n$., fr. icka and ictia; Venusand Jupiter.

ic kă ذ̇á pu a, $n$., fr. icka and sapua ; Ursa Major.

íc ke, $n$.; bands, societies, or se. cret orders among the Hidatsa; each having its own songs, dances, and ceremonies, which are to a certain extent esoteric.

ic ki, comp. pcrs. pron.; himself ; herself; itself; themselres.

ic pa, $n$.; the wing of a birll.

íc pa tạ ki, $n ., f r$. icpa and tạki; a species of bawk.

íc pe, $n$. ; a magpie, the Pica hud. sonica.

\section{ida}

1c pe, $n_{\text {. }}$; the tail of a bird.

ic pu, $n$. ; point, top, extremity, small end ; rame as Dakota inkpa or intpa. For examples, see amaicpu, aziicpu, midaicpu, and sakiicpu.

ic ta ta ki, n.; the kill-deer, Egialitis vocifera.

ic ti a, adj.; great, large.

ic ti á du i, $v$. $i$, fr. ictia; increasing.

ic tí a he, $v$. $t$. and $i$. ; to increase.

ic tí a ke, $v$. t.; to cause to en. lirge or increase; to change from snall to large.

ic tí a ke, enlarged.

i da, $v . i$; to yawn.

i dái lii, n., fr. dalii'; a sbade; its or his shade, shadow, or ghost.

i da lii lii, $n$. , fr. daliilii; a re. flection; his, lier, or its reflec. tion.-madaliilii, my reflection. didaliilii, your reflection.

i dạ hi se, $n ., f r$ i and dạliise ; a shovel; same as a maidahise.

i dă lipi, $v$. $t$.; to make an incised wound.

i dá ka, n., fr. daka; bis or her offspring; their offspring.

i dă lía ki ti, $n$. fr. dakakiti; a rolie-scraper. The term bas been recently applied to razors.

i dă ki sa, n., adj.; left; left hand ; lett side.

i dă ki sa lko a, $a d v$.; at the left; to the left.

i da ko a ka de, $n$. ; the part. ing in the centre of bair of bead.

i da kó e [-la-], $f r$. dakoe; his friend, his comrade.

i da lí́ dsi, $n ., f r$. dakudsj; a swing. See maidakudsi and makadistaidlakudsi. 


\section{idá}

i dá mi $[$ + -mawi], ord. num., fr. dami ; third.

i dlá mi de [-nawi-], $v ., a d j$; almost third.

i dá mi du [ináwiru], $a d v$.; thirdly, in the third order or place.

i dá mi ke, v.t.; to make third, to place in the order of third; made third.

1 la pa, n., adj.; right; right side; right hand.

i da pá lia, $a d v$.; toward the rigbt.

i da pá ko a, $a d v$.; at the right.

i da pu di, adj.; wild or unmanageable, as a wild borse.

i dạ́ spa, $n$.; shoulder; shoulders. i dạ́ spa ki pĕ, comp. $v$.; to carry on the shoulders.

i dái: ti, $n$. ; a wife's brother, or a man's sișter's husband.-dida'ti, your brother-in-law. mada'ti, my brother-in-law.

i da tska ti, $n ., f r$. i and datska. $\mathrm{ti}$; a syringe.-maidatskati is the more cominou form.

i đá wi. See idámi and its derivatives.

i dé, v. t.; to say; to speak.

i dlé ksa, $v . t$; to talk excessirely, to say too much; to be gar1 ulous or too communicative.

i dé ta, n., fr. i, mouth, and deta; the lips, more properly the mucous surface of the lips.-idetaaku-akoka, upper lip. ideta-akumiktakoa, lower lip. See aputi.

i di, $n$. ; blood.

di, $n$. ; penis.

ii di a lii, $v$. $i$.; to sigh:

i Mi é or idiéts, $v$. $t$., $3 \mathrm{~d}$ pers.; he thinks, belieres, or supposes. dadiets, or nadiets, you think. madiets, or badiets, I think.

\section{idr}

I di hu, v. comp., fr. idi and hu; to bleed.

I di i psạ ki, $n ., f r$ ipsaki; a breech cloth.

i dí láá lia, n., ? fr. idiki; popliteal space.

i dí ké di laśa, $n ., f r$ idiki; a garter, or string for securing the legging.

i dI Ki, $n$. ; the leg; the entire lower extremity. - nadiki, my leg.

i dí lai úi ti, n., fr. idliki and uti; head of femur.

i dri ki ú ti o ki, $n$, fro idikiuti and oki; acetabulum.

I di ko a-ma tu", said of a woman's jealousy.

i di pá da i, $v . i ., f r$. idipi and adui ; fattening.

i di pi, v. adj. ; fat, fleshy.

i di pi ke, v. t.; to make fat; fattened.

i di pi ksa, adj.; obese.

i dir sii, n.. fr. disii ; his or her son; their son.

i dir tsi, adj., $v$. $i$.; to have a scent or smell, agreeable or disagreeable.

i dr tsi i sí a, $v$. $i$, fr. iditsi and isia; to smell disagreeably, to stink.

i di tsi i si a ke, $v$. $t$.; to cause to smell badly; changed from an agreeable to a disagreeable odor. The inteusive form is more com. monly used.

i dI tsi ke, $v . t$.; to supply with an odor, to cause to smell.

i dir tsi tsá ki, $v$. $i$., fr. iditsi and tsạki; smelling sweetly, sweetscented.

i dli tsi tsa kí ke, $v$. $t$; t to cause to smell sweetly, to put scent upon, to remove a disagreeable 


\section{idó}

odor; sweetly scented. See kiiditsitsakike, which is the more common form.

i dó pa [+ - nopa], ord. num.. fr. dopa; second.

i dó pa du [inóparu], adv.; secondly, in the second place.

i dó pa du ke, $v . t$; to put in the second place or order.

i dó pa ke, $v$. t., fr. idopa; to place second, to make second.

i dú, $n$.; a womau's elder sister; her or their elder sister. See madu and didu.

i dúx hi, $v$. reflex., fr. duhi ; to lift one's self up, to stand up; to ariso from sitting, but not from lying.-diduhá, lift thyself, i. e., arise!

i clú ka, $n$. ; meat of any kind, particularly dried meat.

i du kir ti, n.; fresh meat; flesh.

i du kisir ti ími di ti, $n$.; frying-pan. See imiditi.

í du pu pi, n., fr. dupupi ; elas. tic band or web.

i dú ti, $n ., f r$. duti, to bind; any thing used to bind, especially a bridle, or a raw-hide or rope tied around a horse's jaw as a bridle. See uetsa iduti.

i ciú tsi, $n$., fr. dutsi; an instrument for taking up or lifting, as a fork.

i há, v. i., adj.; to differ, to be different; other, of another kinl.

i há ali, $v . t$.; to set out fool, to put a feast before a guest ; lately ipplied to setting a table.

i laá du, adv., fr. iha; in another place.

i há ke, $v . t ., f r$. iha; to cause to be different, to change, to alter; changed.

\section{i"lio}

i há ko a, $a d v ., f r$ iha; in an. other direction or place.

i há' ta ha, $v$; t take care, get out of the way, make room.

i hé, interj.; there now! what do you thiuk of that?

i hr̆ sá dlsi ke, $n ., f r$. his̉adsile ; material to dye reddish.

i his si ke, n., fr. hisike; red dye. stuft.

i lia, n., f fr. lia, rough, etc. ; dust, solid dirt; the dirt on a floor or dish, but not soils on clothing.

i liá tsa ki, $\operatorname{adj} ., f r$. ilia; to bo covered with dirt, dirty.

i liá tsa ki ke, $v$ t $t$; to cover with dirt; to throw dirt on.

i lii, $n$.; the forehead.

i lii, $n$.; brided hair; woven fabric. Seo masiilii.

i lii, n.; the omentum, the crop of a fowl. This word and the one immediately preceding are perhaps but diffierent applications of one term.

i lio, n., fr. hypoth. word lio; a body; his or her body; their bodies.-malio; my body. dilio, your body.

i hó a de, $v$. i., comp. fr. ilio and ade; to be sick, to have general disease.-malióadets, I am sick.

i ho ka, $n$.; a fox.

i lio ka da lia, $n$., fr. ihoka and daka ; a fox-cub.

i lio ka ic ke, $n$., $f r$. ihoka and icke; the Fox Band, a secret degree or order among the men of this tribe.

i ho ka í ti pe,.n., fr. ilioka and itipe; a little fall-trap such as boys make for catching foxes.

i" lio laa mi a ic ke, n., fr. ihoka, mia, and icke; the Fox-wo. wan Band, a secret degree or 


\section{ilio}

- order among the females; its members are usually from fifteen to twenty years old.

i lio ka ta ki, n.; Artemisia ludoviciana, or small "sage" of the northern plains. .

i lio ka ta ki-a ku sí pi sa, n.; lit. black sage; Artemisia biennis.

i lio ki, n., fr. lioki ; an oar.

í lio tạ ká du i, $v$. $i, f r$. iliotạki; bleaching, becoming white.

i lio ta ká dsi, $v . i ., a d j$; whit. ish, having a white appearance.

ì lio ta ki, adj., $v$.; white; to be white.

i lió tạ lside, $a d j$; almost white.

i lió la ki he, $v$. $i$. and $t$; ; to whiten; to bleach.

i lió tạ ki ke, v. t.; to cause to be white, to bleach, to wash white, to change from dark to white.

i lin a lia, n., fr. liualia; the knee or knees; his or her knee or knees.-maliúalia, my knee. dilinalia, your knee.

i i ti pe, $n ., f r . i$ ', mouth, and itipe; a lid, the lid of a pot or kettle.

i i psạ kì, n.,fr. ipșạki; a screen; a covering.

i ka, $n$. ; the chin.

1 ka', $n$. ; mother ; my mother ; a mother's sisters. - ikạs is the common form of address.

i liá, $n ., f r . \mathrm{ka}$; his, her, or their daughter.-maká, my daughter. niká, four daughter.

1. ka, v. t.; to see; he or she sees.amaka, I see. ádaka, you see.

i Lá lii, v. t., reflex.; to lean against.

i ka ka, v. t.; red. of ika; look, behold!

\section{iki}

i la a ki, $n ., f r$. kaki; a wheel; a rolling vehicle.

i ka ti pe, $n .$, fr. katipe; a button. See maikatipe, which is more commonly used.

i lia tsu ti, v. reflex.; to scarify one's self; to eut the flesh in mourning. Scarifying the flesh is a common method of showing sorrow for the dead.

i li. $n$. ; a whip.

i' ki, $n$.; beard.

i ki da ka pu si, n., fr. kidaka. pusi; something used to inflate, or fill out. See madạhapi-ikidakapusi.

i ki da ku di, $n .$, fr. kidakudi; a fan. maikidakudi is the more common form.

i ki da tsó pe, $n . . f r$. i', mouth, and killatsope; a kiss.

i ki da tsó pe, $v$. $t$., comp.; to kiss the mouth, to kiss.-imakidatsope, I kiss. idakidatsope, you kiss.

i Li da tá ta, $n$.; an open space in a solid covering, as the fonta. nels of an infint head. This word and the word midiikidutata (which see) are apparently from a verb "kidutata", which, however, I have never lieard except in these words.

i ki ki ski, $n ., f r_{a}$ kikisiki; an in. strument for measuring or determining any qualits.

i ki pa mi di [ikipawidi], $v$. reflex., fr. kipamidi ; to turn one's self around, to look behind.

i ki pa tạ ki, $n$., fr. kipatạki; a bolt or bar for a door; accent also on penult.

i ki pa tó' ti, v. reflex., fr. kipato'ti ; to shake one's self; said of a bird shaking its plumage, of 


\section{iki}

an animal drying itself by shaking; also íkipato’ti.

íli pi, $n$.; a pipe.

i ki pi hu pa, $n$. ; a pipe-siem.

i ki pkí ti, n., fr. kipkiti ; a sadiron.

i ki si, $n$.; a nest, 'a bird's nest.

i Ki tsá ti ke, $n ., f r$. kitsatike; polish, varnish, ete.

i ko ki, $v . t$.; to bang up on a peg or nail.

i lís' pa, n., fr. ko'pa; her friend or comrade.-makópa, my friend.

í lao zi, $n ., f r$. kozi ; a whistle.

' ko hi, $v$. $i$., fr. i' and kozi ; to whistle with the mouth.

Iisi a, $v$. $i$; stuck or stranded, as a ressel.

i tiśu lii, $v$; to dash or splash ; to dash on.

i litsá ti, v. t., ? fr. kitsati ; to be. daub; to apply any solt sub. stance, as mud or molasses.

i lói, $n$.; a grandmother; a grandmother's sisters.

i lír pa, $v . t$.; to arcompanr, to go wilh.

i lár.pa, $a d v$.; with, along with.

i káa' pa, $v$. $t$; ; to hate; he hates.amaku'pa, I hate. adaku'pa, you hate.

i léí, pa dsi, v. t., fr. ikúpa and adsi ; to dislike very much.

i Lin ti, n.; the wrist; his or her wrist.

i kúr ti a du su ka, $n .$, fro. ikuti and adusuka; the wrist, the wrist.joint.

i léú tslii, n., fr. kutski ; a meusuring-stick; a pattern. See maikutski, which is more commonly used.

i mă lipi [i [ư̆ălipi], $v$. $i$. and $r e$. flex.; to set; said of heavenly bodies.

\section{ipa}

í mă lipi de, v., $a d v$.; almost setting; near the time of setting.

i mă lipi du [iwălipiru], $a d v$, at the time of setting.

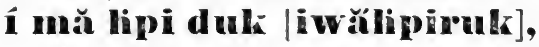
adv. of future time; when it will set.

í mă lipi se du, adv. of past time; when it did set, at last time of setting.

i mạk i [iwạki], n., ? f̦. mạki ; the chest, the sternal region.

i mạk i e ke, $n ., f r$ i and mạki; gaming materials; cards.

i mạk i du, a contraction of imakihidu, and more commonly used than the latter.

í mạk i hi" du, $n$., fro imạki and hidu; the breastbone, the sternum.

i mạla i ka ti pe, $n ., f r$ imạki, the chest, and ikatipe, or fr. i, maki, and katipe; buttons which join a garment in front.

i mạk si di, n., lit. tacny breast; the western meadow-lark, Stur: nella neglectu.

i ma si, $n$. ; price, value.

i mi a [iwia], $v . i$; to weep; to cry and weep.

i mi a le, $v . t$; to cause to ery. i mi dî pi lie, $u ., f r$ midipi; a sponge.

I mi di ti, $n ., f i$ miditi; a frying-pan.

i ó pe, $n .$, fr. ope; a receptacle, a box.

i ó ki, n., fr. oki; a receptacle which closely surrounds or encircles, as a caudlestick, a socket.

i ó ptsa ti, $n$., fi. optsati ; uearly synonymous with ioki. See sakioptsati.

i pạ lia dé, n., fir. i and pạkade ; a fork. 


\section{ipa}

i pa san ki, $n ., f r$. i and paśaki ; a belt; same as maipaśaki.

i pa ta ki, v. $i, f r$ patạki; to come in contact; to lean against.

i pa tsa' ti, n., fr. patsa'ti; a skewer or fork.

i plio ki, $n$.; a species of eagle.

i pi, v.t.; to cohabit.

i pi ta, $n$. ; behind, the rear, the back part of anything.

i pi ta ,du, $a d v ., f r$. ipita; in the rear, in the back part; after, following.

i pi ta lia, adv.; toward the rear, backward.

i pi ta ko a, adv.; at the rear, behind.

i pki ti, v. t.; to smooth out; to spread smoothly; to coat or corer smoothly, as in spreading butter or mortar.

i.psa ki, v.t.; to conceal, screen, hide from view.

I ptsa, $n$.; an upright, a supporting-post or pillar.

i ptse, v. t.; to garnish, to embroider with beads.

i $\dot{\mathbf{s} a}, n . ;$ tooth ; teeth.

i sa, adv., suf. to verbs, etc.; alike, resembling; nearly resembling.

isia, adv.; thus, in this manner.

i sa, conj.; and, also.

i sạ ki, n., fr. saki; his or her hand. See saki._masaąki, my hand. dișąki, your band.

i sạ ki a du tsá mi he. See sakiadutsamibe.

i śa ki ic pu. See sakiicpu.

i śé nu [ísííwi], n.; an aunt; his or her aunt; a father's but not a mother's sisters.-maśami, or maśawis̉, my aunt. dis̉ami, or nis̀awis, vour aunt.

i śé mi ke, $v . i$; said of joung sprouts growing from a stump.

\section{ist}

i sa tsa, $a d v$.; gratuitously, without reward.

I še, same as is̉a; alike, resembling.

i si, $n$. ; a ressel, box, sack, cover, or receptacle of any kind.

i si a, $v .$, adj.; bad.

i sí á du i, $v . i, f r$. is̉ia and adui ; deteriorating.

i sí a ke, $v$. $t$.; to make bad, to spoil, damage, ruin.

i sií a ke, damaged, ruined.

i si ta, $n$.; the back; his or her back.-masita, my back. disita, your back.

i si ki si, $n$. ; a brother-in-law, a woman's husband's brother; his or her brother-in-law.-misikisi, my brother-in-law. disikisi, your brother-in-law.

i si pi he, $n ., f r . \mathrm{i}, m o u^{\prime} h$, and sipilhe; Mouth Blackeners, an order or degree among the Hidatsa men.

i sí pi sa ke, $n$., fr. sipisake; dye-stuft for coloring black.

i ske', v.t.; to command or direct.-amas̉ke, I direct.

i spar lii, n., ? fr. palii ; the elbow ; his or her elbow.-mispalii, my elbow. dispálii, your elbow.

i sta or I sta, $n . ;$ an eye; eyes.

i sta dă lipi, $n$., fro is̀ta and dalipi ; the eyelids.

i sta du i lió ta ki, $n$., fr. issta, adu, and iliotaki; the white of the eye.

i sta du sí pi s̀a, $n ., f r$. is̉ta, adu, and sipisa; the pupil.

i sta dí ta, $v$.; adj., prob. fr. ista and duti, to bind; squint-eyed.

i sta liú lii, $v$. $i$; ; to wink.

i sta mi di [-bidi], $n ., f r$ is̉tn and midi ; tears.

i sta ó ze, $n ., f r$ isita and oze ; an eye-water. 
ist

i sta pé di, $n ., f r$. ișta and pedi; purulent or mucous matter ad. hering to the eyelids.

i st tá pi, $n$.; eyelashes.

I su, $n$. ; quills ; primary feathers of wings of large birds, particu larly of eagles' wings.

i su a ti si a, n., fr. isu and atisiat; a bat.

I ju sir sa, $n$.; a species of kingbird, Tyrannus verticalis.

i sil ti, $n$.; the lap.

i su tI psạ ki, n., fr. isuti and ipśaki ; an apron.

i tá, n., fr. i and ta ; an arrow, lit., an instrument of death. See maita.

I ta or i ta, comp. pers. prom., 3d pers., sing. and plur., possessive, and used for all genders; denotes principally acquired or transferable possession. ita (or its equivalents in the fi.st and second person,-mata and dita) is prefixed to nouns, forming compounds which often differ so much from the original nouns in sense or sound that they are to be regarded as distinct words. $\Lambda$ few examples follow. ( $(\uparrow / 58$ (ii).

i tá da mi a [itarawia], $n ., f r$. mia; a wife; a betrothed wife; a wile's sister.

I ta dé lipa, $n$.; the navel.

I ta do lipá ka, $n$., fr. ita and dolipaka; one's own people, relations, kindred.

ì ta dó ta du [-lotaru], $n$, $a d v ., f r$. ita and dotadn; this side of it; a place nearer than some given point; used also in comparison of adjectives to denote a less degree, or inferiority. 233).

\section{ita}

i ta dó la ko a, adv., fr. dotakoa; "at this side of it", at a point nearer than some given point whose name is the antecedent of ita.

i tá du $[-\mathbf{r u}], n . ;$ a mother's brother, his or her mother's brother, uncles in the female line.-matádu or matárus, my uncle. ditádu or nitáru, your uncle.

I ta dú lia, $n ., f r$. midulia; one's own gun or bow.-matadulia, my own gun. ditadulia, your own gun.

I ta dún lia ke, $n ., f r$. miduliake; one's own pop-gun.

I ta du liạ pị, $n ., f r$ aduliạpi; one's own bed._mataduliapi, my own bed.

I tá dsi, $n$. ; leggings; his or her leggings.-matadsi, my leggings. ditadsi, your legaings.

I tá dsi-ó da láa pi lii, $n$., fí. itadsi and odakapilii ; the flap or fringe worn on the outer seam of the legging.

i ta há tslii, $n$., fr. ita and hatski, lit., Long Arrous; the Dakota Indians.

i ta bi', $n ., f r$. ita and hi'; an arrow-point.

i ta hu, $u_{\text {. ; }}$ a mouse.

i ta hu ic ti a, $n ., f r$. itahu and ictia; a rat.

i tá ì su, $n .$, fr. it á and is̉u; the quills at the base of an arrow, arrow-directors.

i tá ka, $n$. ; an aged man; a venerable person.

i tá ka lie or itákaliie, $n ., f r$. itaka and lie; a very old man.

i ta ka té tas, prop. n., fr. itaka, te, and tă, lit., Old Man Immortal; one of the Hidatsa names for a Deity. 


\section{ita}

1. ta ki, n., fr. i, hair, and tạki, vohite; the jackass rabbit, or Lepus campestris, which turns white in winter.

i ta ki da ká he, $n$., $f r$. kidakahe; a span, the outstretch of the hand, the measure of a span: See sakiitakidakahe.

I ta ki sa, $n$. ; a sister; a man's younger sister. - matakiṡa, my sister. nitakisa your sister.

i tạ lksii pi sà, $n$., fr. itạki and sipisia; the s mall rabbit, the "wood-rabbit", Lepus sylvaticus var. nuttalli.

i tái ku, $n$. ; a woman's younger sister; her younger sister.-mataku, my sister. ditaku, your sister.

i ta kú pe, $n$. ; an owl, particularly the great horned owl, Bubo virginianus.

1. ima, $n ., f r$. ita and ama; one's own country, the proper hunting-grouud of any tribe.

i ta má e, $n ., f r$. ita and mae; one's own property; his own property. - matamae, my own. ditamae, your own. ( $(\mathbf{1 2 2}$ ).

i ta ma pri sa, n.; grandehild; his or her grandchild.

L ta má si, $n$.; a servant; used when speaking of white meu.

I ta ma sún ka, $n$.; his dog.

i tá ma ta, adj., alv.,fr. ite, ama, and ta; face downward; with the face to the ground.

i ta mé tsa [-wetsa], $n$., ? fr. matse; a brother; brethren (in the widest sense); this is also the only term for a woman's elcler brother.-matametsa, my brother.

i ta mi a [-wia], $n ., f r$. ita and mia; a man's elder sister.-ma.

\section{ité}

tamia, my sister. ditamia, your sister.

i ta o la du, $a d v ., f r$. ita and okadu; the other side of it, on the other side of it, in a place further off than some object mentioned. This word and the next following are commonly used in comparison of qualities to denote superiority,-the anteced. ent of ita being the inferior. (โ233).

I ta 6 ka ko a, $a d v$., $f r$. ita and okakoa ; at the other side of it, beyond some object mentioned.

I ta ó ki ko a, a rare pronunciation of the word immediately preceding.

1 tá pa, $n ., f r$. ita and hupa ; moccasolns; his or her moccasons.matapa, my moccasons.

I tá si, $n ., f r$ ita and masi; his or her own robe or blanket.-matasit, $m s$ robe.

i tái si i ptsi, n., fr. itasi and iptsi (see masiiptsi); the garnishing of his or her robe.

i tá su, $n$., contraction of itaisu.

i tái su ka, $n ., f r$. ita and itsuasuka or suka; one's own horse.matásuka, my horse.

i tá su pu zi, n., fr. itasiu and puzi, lit., Spotted Arrovequills; the Cheyenne Indians.

i tai tsu, $n .$, fr. ita and tsu; the half of anything.

i tón tsu he, $v$. $t$., fr. itátsu; to divide into its halves; also used as a noun or adjective, signifying half or halved.

I ta we tsa, n., same as itametsa.

l ta wi a, $n$., same as itamia.

i té, $v . t$.; to admire; to be fond of.-amatets, I admire. adatets, sou admire. 
ite

1 te or itè, $n$. ; the face.

i tě á ka ta, adr., same as italiata.

i te á ma ta, adr., same as itamata.

i tè lia, adv., fr. ite; toward the face or front, forward.

i te i si a, $v . i$, adj., fir. ite and isia ; to be ill-farored; ugly.

i té ko a, adre, fri. ite; at or to the front or face, in front.

1 tè ko a hi, adr of time, $f r$. itekoa ; soon, presently, at a future time not very distant.

i té lio a hi duk, adv of time, fr. itekoahi; soon, in a little while; when, or if, a future time not very distant arrives.

ite ma tse e" tsis, $n$. See Local Nimes.

i te ta, adx. and $u_{\text {. }}$; on the face; the cheek.

i té ta a du ho pi, $n$.; a dim. ple.

i tè tsa ki, $r . i ., a d j ., f i$. ite and tsaki; possessed of a handsome face, pretty.

i te í i, n., fr. ite and ui ; rermilion or other pigment used in painting the face.

i ti pe, $n ., f r$. i and tipe; something which closes or covers, as a lid, a fall-trap, etc. See mai. tipe.

i tó di, $v$. i., ? reflex.; to be ashamed of, to feel shame.

i tó di ke, $v$.t.; to cause to be ashamed, to shame.

i tó hi ke, $n ., f r$. tohike; dyestuff for coloring blue.

i tó hi si ke, n., fr. tohišike; material for dyeing bluish or green.

i tó pa, ord. num., fr. t o p a ; fourth.

\section{its}

i tó pa du, $a d v ., f r$. itopa; fourth. ly, in the fourth place or order.

i tó pa du ke, $v$. $t$., fr. itopadu; to put in the fourth place or order.

i tsa ki, $v$. comp., often used as pronoun, $f i$. i and tsaki; he, she, or it alone; he by himself, un. aided.-mitsạki, I alone. ditsạki, sou alone.

i tsá ti, n., fr. i and tsati; oil or other material used to reuder a surface smooth.

i tsá 1i, $n$. ; the Isanti or Santeo Dakotas. This word is simply the Hidatsa pronunciation of the Dakota word.

i tsa í zi e, $v . t ., f r$. uzie; to meet another person face to face, to meet in coming from opposite directions.

i tsé, v., ? reflex.; to waken up, to arouse one's self.

i tsí. See itsii.

i tsi, $x . i_{\text {. }}$; to be awake.

I Isi, $n$.; the human foot; the claws of a fowl; the hind paws of a quadruped.-matsi, my foot. ditsi, your foot. Ytsi, his foot. See tsi.

I tsi a du tsá mi he [-wihe], $n . ;$ the toes.

I tsíc pu, n., fir. itsi and icpu; the toe.nails.

i tsí di ke, n.,fi. i and tsidike; yellow dye-stuff, a lichen found br the Indians on dear pine-trees in the mountains. The name has been recently applied to turme. ric and other sellow dyes ob. tained from the whites.

i tsi he, $v . t ., f r$. itsi ; to arouse another person.

i tsi i, $v$. $i$. and $a d j$.; to be strong; 


\section{its}

physicaliy strong; said of organized beings.

i tsi i ke, v.t.; to strengthen; strengthened.

1 tsi ka, $a d v$. and $a d j$. ; first, foremost.

I tsi ka ko a, $a d v ., f r$. itsika; formerly, in the beginning, very long ago; used in reference to very remote past time.

i tsi ka ma hi dis, $n ., f r$. itsi$\mathrm{ka}$, ma, and hidd ; one of the $\mathrm{Hi}$ datsa names for their Deity, or object of greatest veneration.

i tsi sí pi sa, $n$., fr. ítsi and sipisa ; the Blackfoot Indians.

I tsil ti, $n ., f r$. Itsi ; a foot-print, a track; his, her, or its foot-print.

i tš̆ tsá du i, $v$. $i ., f r$. itsitsi ; becoming very bright.

i tsi tsi, $v . i$., adj.; very bright, gleaming, respleudent.

i tsî Isi ke, $v . t$.; to cause to brighten; made bright.

i tski, $v . i_{0}$; to be large enough for a purpose, to contain, to accommodate; said if it is desired to cut a pair of moccasins out of a piece of buckskin, and, on lay. ing on the pattern, the piece is found to be large enough, ete.itskitats, it is not large enough.

i tskí ti, n., fr. i and tskiti; an instrument for shearing off, or cutting close, as a scissors. See maitskiti.

i tsú a su ka, $n ., f r$ s suka; a horse. The meaning of the first three syllables is not now known. Some of the tribe think that the word was originally itsímasiuka, the 'strong dog' or 'strong beast of burden'.

i tsí ka, $n_{\text {. }}$; a man's or woman's younger brother.-matsuka, my

\section{kad}

brother. ditsuka, or nitsuka, your brother.

i ṫ̉í a su ka. See itsuasuka, which is sometimes pronounced thus.

i tú di, $v . i ., a d j$. ; containing pas, purulent, suppurating.

i tú lii, n.; a dress, coat, or shirt; one's own dress. - matúlii, my coat. dituhi, sour coat.

i tú ka, same as itekoa.

i tu pá, $n$.; any wild feline, par. ticularly the Canada lynx, Lynx canadensis.

i tu pa ic tí a, n., fr. itupa and ictia ; the puma, Felis concolor.

i tu pa pú zi, n., fr. itupa and puzi; the red lynx, Lynx rufus.

i wạ ki, same as imạki.

\section{k.}

ka, prep.; at; in ; suffixed to nouns, it forms adverbs of place. ka, hypothetical word for daughter. See iká.

ka, an adjective, or qualifying suffix, denoting quantity.-tuaka, how much? hídika (or hídikats), this much, so much.

ka, $2 d$ pers. of ke, an auxiliary suffix ; to make ; to cause.

ka', $v$. $i$; to laugh.

ka dái, $v . i$.; to flee from, to run away.

kạ da lia, $v$. t., prob. fi. ki and adalia; to kindle.

ká da mi [-wi], v.t.; to remember, to recollect.

kạ da mi ke, $v . t$.; to cause to remember, to remind.

ka dá tsi, $v . i$; to be willing.

ka dán tsi ke, $v$. $t$.; to cause to be willing, to persuade or induce. 


\section{kad}

ka dé [karé], $v$; to romit.

ka dé ti, $v . i$; to have a desire to vomit, to feel nausea.

ka alé kisa, to romit excessively or continuously.

ká di, v. t.; to ask for a gift, to beg.

ka díc ka [-ric-], n.; lightning.

kár di lisa, v. t., fr. kadi; to beg excessirely, habitually, shamelessly.

la all sta [-ri-], adj.; small; refers to size, not quantity or number.

ka dĭ itá du i, $v$. i.,fr. kadista; decreasing gradually in size.

ka dY sta de, $a d j$; almost small ; almost small enough.

ka dri sta di, adj.; very small.

ka dr sta lie, $v$. $t$.; to cause to be small; decreased, diminished.

ka dY sta kja, adj.; constantly small.

ka dI tska [-ri-], adj.; to glisten, to shine brightly by reflected light.

ka elr tska pa [-ri-], $v$. i.; to stick; to adbere, as a glued or pasted surface.

ka Ir tska pa he, $v . t$; to stick, to place in contact with an adhesice surface.

ka II tska pa ke, $v$. $t$.; to cause to adbere, to apply an adhesive substance.

liá alse, $v$. $i$. and $t$.; to blow with the mouth; to blow away.

ka dú, $n$.; a season of the year, a period of time marked by some natural phenomenon.

ka dí du, adv.; during the season.

ká du lie, $n$. ; an old roman. lie is an adjective signifying old,

\section{kar}

and kadu is, I doubt not, the original noun; but $I$ have never heard it without the adjective suffixed. See itaka and itakalie.

ka e, $v . t$.; to scratch with the nails.

ká he, $v$. $t$; ; synon. dakábe.

ka hé, v. t.; to set free, to liberate.

ka' ke, $v . t$., fr. ka'; to cause to laugh. - ka'ike, it makes him laugh.

ka ké ki, $v . i$; to make a loud rattling or stamping noise.

ká ki, v. $i$; to roll, as a wheel.

lka lil lii, adj.; round, circular.

ka kî lii de, adj.; almost circu. lar; irregularly circular.

ka lil lii le, $v$. $t$.; to make circular; to cause to be circular.

ká kja, $n$.; any large tuber, as the potato, wild artichoke, etc.

ká lisa, $v$. $i ., f r$. ka'; to laugh excessively.

ka kú i, $n$. ; a squash.

lái mi [-wi], same as komi, which is more common.

lia míc ka, adj.; tough, hard, and elastic.

ka míc ki su, adj., fr. kamicka and isu; the name of a waterfowl, which sheds its quills on lakes. The quills are collected by the Indians on the leeward shores, split, dyed, and used in embroidery like porcupine quills. The name applies to both bird and quills.

ká mi he, same as komihe.

kạ pe, or kappi, verbal root; scratch, lacerate. See adakạpi, dukapi, etc.

ká ptsi, verbal root; nick, notch.

ka rá, same as kada.

ka rậ tsi, same as kadạtsi. 


\section{kar}

Ka ri sta. See kadista and its derivatives.

kạ ta ke, $v$. t.; to turn inside out; to roll up the sleeres.

ka' ti, $a d j$. and $a d v$; true, real; truly, really; exceedinglr.

ka ti a, $a d j$; extended, as the arms in yawning, as the hands outspread.

ka tí he, $v . t$.; to extend, to stretch out.

ka ti ke, $v$.t.; to change, or pour, from one ressel to another. katika.

kạ tsi, $v$; to make a buffalo.surround.

Kạ tsi, $v$. $i$. , adj.; to be extinguished, as a light or a fire; to be cooled by being blown on with the mouth, or by being taken from the fire and set aside to cool.

kạ́ tsi he, $v$. $i ., 3 \mathrm{~d}$ pers.; to cool by blowing, etc.; to extinguish a light or a fire.-kạtsimats, I extinguish. kạtsidats, you extinguish.

ka tsí ka, adj.; to be swollen and bardened, as a diseased joint, or a cicatrix on a tree.

ka ú sta, $a d j$; s small in quantity or number.

ka í sta-ali" pi, $n .$, adj., $f r$. kausta and alipi; a small part or portion; fractional.

ka úl sta le, $a d j$; almost too few.

ka í sta li, adj.; rery ferr; a very small quantity.

ka íl sta du i, $v$. $i$; decreasing in number or quantity.

ka il sta ke, $v$. $t_{\text {. }}$; to cause to decrease in number or quantity; reduced in numbers.

ka wíc ka, adj., same as kamic-

\section{kia}

ka, and a more common pronunciation than the latter.

ka wíc ki su, n., same as kamickisuru.

ká za, a diminutive of limited use applied to about twenty words of the language.

kái zi, same as kaza.

ke, $v . t$.; to give a way, to present. ke, $v . t$. ; to scratch, as in reliering an itchy. sensation; synon. with kae, of which it mas be a contraction.

ke, a suffix to rerbs, adjectires, etc., or a verb auxiliary; to make, to cause; to change condition; to use as. Where ke is suffixed, ki is commonls prefixed. In the sense of "to use as", it is added to nouns; and the words thus formed may be used as nouns; as, makadistake, a doll, from makadista, a child; midu. liake, a pop-gun, from midulia, a gun.

ki, $v . t . ;$ to bear on the back; to carry a heary load.

ki, an intensifying prefix to rerbs denoting that the action is done forcibly, completel $y$, frequently, under circumstances of difficults, etc. ki often merely strengtheus without altering the meaning-the intensified word requiring no separate definition; but in other cases it totally changes the significance.

ki, an interjection, u sed when something false or absurd is heard.

ki a a ti, $v . t ., f r$. aati; to hit severely with a missile.

ki a dắ du i, $v . i ., f r$. adadui ; becoming rapidly and exceedingly painful. 


\section{kiă}

ki ă dă lia, $v$. $i$., fr. adalia; to be burned up, consumed by fire.

ki ă dă lia ke, $v$. $t$.; to cause to be consumed by fire; to burn up, to reduce to ashes.

ki ă dă liă pe, $v$. $t$., fr . adaliape; to kick severely.

ki ă dlă lié lie, $v$. t., fr. adalielie; to hold securely.

ki ă dă lié see, $v$. $t$., fr. adalièse; to tear to pieces with the foot.

ki ă dă lió lii, intensive form of adaliolii.

ki a dạ lipi ke, synon. with adalipike.

ki ă dă liú e, $v \cdot t$., frir. adaliu; to orerthrow completely, or by kicking violently.

ki ă dă kạ pe, $v$. t., fr. adakạpe; to scratch vigorously with the paws; said when an animal tears up the ground by scratch. ing.

ki ă dă kî de, $v$. $t$., fr . adakide; to push completely away with the foot.

ki ă dă kí ti, $v$. $i, f r$ r. adakiti ; said of a wide stretch of country, that has been thoroughly cleared by fire.

ki ă ală mí di, $v$. $t$, intensive of adamidi.

ki ă dă pa pă du i, $v, i, f r$. adapapi ; becoming rapidly and extensively scorched.

ki ă dă pá pi, intensive of adapapi.

ki ă dă pá pi lie, $v$. $t$.; to cause to be extensively scorched or chapped.

lii ă lă pe, $v . t$., fr. adape; to kick angrily or repeatedly.

ki ă dă síl ki, $v . t$., fir. adaśsuki; to completely erase with the foot.

\section{kíă}

ki ă dă tạ pi, v. t., fri. adatạpi ; to squeeze sererely under foot.

ki ă dă te, $v$. $i$, intensive form of adate.

ki ă dă té he, $v$. $t$., fr. adatéhe; to kill a number by trampling, to kill a brood of young birds by accidentally stepping on them, to trample a number of insects to death.

ki à dă tó' ti, $v \cdot t, f^{\prime}$. adató'ti; to shake rigorously or entirely with the foot.

ki ă dằ tsạ ki, $v$. $t$., fr. adatsa$\mathrm{ki}$; to divide a thick bods rapidly by fire.

ki ă da tská pi, $v$. i., intensive form of adatskapi.

ki a dạ tsku ă lu i, $v$. i., fr. adạtskuadui; becoming wet throughout.

ki a dạ toku i, v. $i, f r$ adạtskui ; entirely wet, etc.

ki a dá toliu i ke, $v$. $t$.; to moisten thoroughly or rapidly.

ki a lé, $v ., f r$ ade; to pain exceedingls.

ki a dé a du i, $v$. $i$; becoming very sultrs.

li a dé he, $v$. $t$.; to be very angrs; to become suddenly very augry.

lii a dé ke, $v$. t.; to make exceedingly painful, etc.

ki a lě tsi, adj.; to be possessed of admirable qualities, to be brare, skilful, intelligent, ingenious, enduring, etc.; to be skilled in any particular art or calling.

ki a de tsi ke, $v$. $t$.; to cause to be brave, enduring, or skilful; to instruct thoronghly in any art.

kí ă di a sá dsi ke, $v, t$, fr. adi- 


\section{kiă}

'asadsike; to impoverish greatly, to render destitute.

ki ă dii i tăi du i, $v . t ., f r$. adiiti; becoming ravenously hungry.

ki ă di i ti, $v$., intensive of adiiti.

ki ă di í ti ke, $v$. $t$.; to starre, to deprive of food.

ki a du ă du i, $v$. $i$., fr. aduadui; becoming entirely or excessively bitter.

ki á du i, $v . i ., f r$ adui; entirely bitter.

ki ă du i ke, $v$. $t$.; to render completely or exceedingly bitter or pungent.

ki a hú ke, $v . t ., f r$. ahuke; to multiply rapidly, to increase largely and rapidly; to increase every one of a number of ob. jects.

ki a lió e, v. t., fr. alioe; to conceal carefully or completely ; to conceal all.

ki a kạ lipi, $v$. t., fr. akạlipi ; to step completely over a wide space; to cross a chasm success. fully but with difficults.

ki a ká ma he, $v$. t., intensive form of akamahe.

ki a ká ma he ke, $v$. $t$.; to divide completely into six equal parts.

Ki a ká ma ke, divided into six equal parts.

ki á ka pe, $v . t$., fr. akape; to court assiduously.

ki ak' de, $v$. $t ., f r$. akde; to seize and bear off; to carry to a dis. tance; to carry the entire of any. thing away.

ki ak' hu, $v . t ., f r$ akhu ; to bring with difficulty, or from a dis. tance; to bring all.

ki á ki ka he, v. t., fr. akikahe; said when something is captured

\section{kia}

and brought from a distance; as when a war-party brings home a prize in haste and danger, but in triumph.

ki an ki tsa, $v . t ., f r$ akitsa; to miss widely; to miss at evęry trial. .

ki ak' si e, v. t., fr. ạksisie; to hold firmly.

ki ak' su e, $v . t ., f r$. aksiue; to spit on repeatedly.

ki ak' tsi je, v. t., fr. aktsiš ; to look long or scrutinizingly through a door or window.

ki a ma hó ka, $v$. $i$, fr. amahoka; to be far within; deep under ground.

ki a ma hó lia ke, $v$. $t$.; to place far within; to put all in.

Ki a má ki, $v$. $i$; to remain sitting long or steadily.

ki a má ki ke, $v$. $t$., fr. amakike.

ki a má ton ki, $v$. i., intensive form of amatsaki.

ki a má tsa ki ke, $v . t$.; to soil entirely with earth; to soil all of a number of objects with earth.

Li a pá di, $v$. $i ., f r$. apadi; to grow vigorously.

Li a pár di ke, $v . t$.; to cause to grow vigorousls; to cause all to grow.

ki á pi ke, v. t., fr. apike; to place together closely or contin. uously.

ki a tá di, $v . i ., f r$. atadi; to go out and remain out; said, too, when a number of individuals go out from a house.

ki a tá di ke, $v . t$; to canse to go out, etc.

ki a tạ́ ki ke, v. t., fr. atạkike, to render completels white. 


\section{Kia}

ki a tá zi lio a, $v$. $i$, intensive of atazikoa.

lii a té, $v . i ., f r$. ate ; to come into full view; to come suddenly into full riew.

ki a té he, $v$. $t$.; to present immediately to full view.

li a té he ke, $v$. $t$.; to cause to appear entirely ; to exhibit all of a number of objects.

li ă tskă, intensive form of ătskă.

ki ă tskăi du i, v. i., fr. ătskădui; becoming rapidly vers fierce.

ki ú tskă le, $v$.t.; to persistently aggrarate to fierceuess.

lii dán, $n$.; a husbaud.

ki da he, $v$. t., fro kida and he; to marrs; said of the woman, if the marriage is informal or against parental consent.

ki da hé, v., same as kiduhe, which is more common.

ki da he liá' ti lie, $v$. t., intensixe form of dahekátike.

Li da liạ pe si, $v$. $i ., f r$ daliạpesi ; to rise perpendicularly to a great height; to extend perpen. dicularly to a great length.

lai da liạ́ pe si lae, $v$. $t$; to cause to be perpendicular to a great height or length.

ki da liá pi, $v$. t., fir daliapi ; to peel entirely, to strip a tree bare.

Ki da lié :i, $v$. $i$, fro daliési; toru to shreds with teeth.

ki da lié si lie, v. t.; to cause to be torn to shreds with teeth.

lii dăi lii se, $v$. t., prob. fr. ki and adăliise ; to forget.-makidalii. sets, I forget. dlakidăliisets, you forget. kidaliisets, it is forgotten.

ki da lii pi, v. i., intensive form of daliipi.

\section{kid}

ki dạ́ lipa, $v$. t., fr. dạlipa; to embrace, to hug.

ki da liú e, $v$. $t$., fr. daliue; to spill or overset completely and forcibly.

ki da liú pi, $v$. $t$., fr. daliupi ; to drink or absorb a large amount completely and rapidly.

ki da ká he, $v$. t., fri. dakahe; to stretch completely out.

ki da ká hi si, $v$. $t$, fr. dakahi$\mathrm{si}$; to carry in the arms; to hold long in the arms.

li dăk a lió lii, v. t., fr. dakaliolii; to break completely across with a blow; to break something large, or to break a number of objects across with a blow.

lai dăk a lá ti, $v$. t., fr. dakakiti; to scrape the hair eutirely awar.

ki dăk a mí di, $v . t$, fr. dakamidi; to turn completely by force; to twill tightly by sudden force.

lai dăk a mi di ke, $v$. $t$; to cause to turn completely by sudden force.

ki dăk a mî̀ tsi, $v$. $t$., fr. dakaunitsi; to mince completely, to ehop tine all that is given to be chopped.

ki dăk a pạ́ ki, $v$. i., fro dakapạki; to bloom fully; to expand numerous blossoms.

ki da kạ́ pe, v. t., intensive form of dakape.

ki da kái pi, $v$. $t$.; to pick out, to cull, to separate; to pick grain from chaff, stones from coffee, etc.

lai da ka pri lii, $v$, $f r$. dakapilii ; to tloat well or continuously.

ki da ka pr̆ lii ke, $v$. $t$.; to 


\section{kid}

cause to float continuously; to cause all to float.

ki da kạ́ ptsi, v. $i$., fr. dakạptsi ; covered with nicks or tallies.

ki da ka pú si, $v$. $i, f r$. dakapusi ; greatly inflated; permanently inflated.

ki da ka pú si ke, $v$. $i$.; to inflate extensively or permanently.

ki dăk' a ta, v. t., fr. dăkata; to smash completely; to smash and resmasb.

ki dăk a tại lii, $v$. i., intensive form of dăkatalii.

ki dán-ka' ti, $n ., f r$. kida and ka'ti; a first husband.

ki dăk a tó' ti, v. t., fr. dăkato'ti ; to shake repeatedly or continuously with force suddenly applied.

ki dăk a wí di, same as kidăkamidi.

ki dăk a wí tsi, same as kidăkamitsi.

kí da kí ti, $v$. $i$, fr. dakiti and nearly synonymous with it, but more commonly used.

ki lăk já ki, $v$. $t, f i$. dăksạaki ; to wound repeatedly or severely by throwing missiles.

ki dăk $\mathbf{k}^{\prime} \mathbf{s i}, v . t$; to bundle securely or completely.

ki lăk sí pi, $v$. $i$, intensive form of dăksipi.

ki dăk sí pi ke, $v$. $t$.; to cause to be much later.

ki dăk tá de, $v . t$., fir. dăktáde; to drive hard; to nail securely or completely.

ki dăk tsá da ke, $v$. $t$.; synon. with dăktsadake.

ki dăk tsạ́ ki, $v$. t., fr. dăktsa$k i$; to chop all up ; to chop into numerous pieces.

ki dăk tsá ti, v. t., fr. dăktsa.

\section{kid}

ti; to impale securely or frequently.

ki dăk tsí, $v$. $i .$, ? fr. dăktsia; to settle as water; also kidaktsio.

ki dăk tsi á du i, $v$. $i$.; increasing rapidly and greatly in weight.

ki dlăk tsí a ke, $v$. $t$., intensive form of dăktsiake.

ki dăk tsi ke, $v$., fr. dăktsike; to continue, remain, or follow one another, in single file; said of the motion of a flock of wildgeese, or of a band of antelope running after their leader.

ki dăk tsú ti, v. t., fr. dăktsuti; to braid completely.

ki dăk ú di, $v$. $t$., fr. dăkudi; to fan ; a form more commonly employed than dăkudi.

ki dăk ú dsi, $v$. $t$, fr. dăkudsi ; to swing vigorously or continuously.

ki dăk ú dlsi ke, v. t.; to cause to oscillate continuously.

ki dăk ú liti, intensive form of dakuliti.

ki dăk ú liti ke, $v$. t.; to decrease greatly or rapidly in weight.

ki da mi hé ke [+ kinawihele], $v . t$., fr. damiheke; to divide completely into three equal parts; divided equally in three.

ki dá mi ke, same as kidamiheke.

ki da mí tsi, $v$. t., intensive form of damitsi.

ki da mó ki, $v$. $i$; to ebb a rray, to sink down, to fall as a river.

ki dá mu ke [ki ná wulke], $v$., fr. daunke; to c'eepen great15 , rapidly; or thronghout.

ki lár pe, $v$. $t$., fr. dape; to de- 


\section{kid}

sour by tearing, to tear meat with the teeth and devour it.

ki da píu ti, v.t., intensive form of dapsiuti.

Li lá sa, $v$. $t$., frr. dasia; to cut extensively or severely with the teeth.

ki da sí pi, $v$. t., fro dasipi; to untie completely with the teeth.

ki dá sliu, v. $t$., fr. daśku; to take out with the teeth something difficult to extract.

ki lá ste, $v$. $t$, f $r$. daste ; to com. minute completely.

ki da' ta dé sa, $v$. i., fr. da'ta. desia ; to be completely inconsid. erate, etc.

lii da' ta dé sa lie, $v$. $t$.; to cause to be inconsiderate, ete.

lai da' ta lié pi, $c$. $i ., f r$. da'taliepi; to be thoroughly lazy, or always lazy.

ki da' ta lié pi ke, $t$. $t$.; to cause to be lazy.

ki da' ta i si a, $v$. i..,fi. da'taisia ; to be miserable or despond. ent; to be continually unbapps, sorry or ill tempered; said too of a number of individuals who are unbapps.

ki da' ta i si á du i, $v$. $i$; becoming very unhappy, misera. ble, etc.

ki da' ta i si a ke, $v$. t.; to make constantly unhappy, etc.

ki da tạ pi, $v$. t., intensive form of datapi.

ki da' ta toạ ki, $v$. i., fr. da'tatsaki; to be very happy; constantly happy.

ki da' ta tsa ki ki, $v$. $t$.; to render very happy; to make all happs.

ki da' ta tsó ki, $v$. $i$, intensive form of da'tatsoki.

\section{kid}

ki la' ta tsó ki ke, v. t.; to render very resolute; to inspire all with resolution.

lic da tó' ti, $v$. t., fir. dato'ti; to skake vigoronsly in the mouth; to worry to death by shaking in the mouth.

ki dă tsa, $v$. t., fir. latsa; to bite severely or repeatedly.

ki da tsá ti, $v$. t., fr. datsati, and nearly or quite synonymous.

ki da tsr pi, $v$. $t$., fro datsipi; to lick repeatedly and continuous. $\mathrm{Iy}$; to lick all over.

ki da tská pi, $v$. t., intensive of datskapi.

lí da tská ti, $v$. $t ., f i$. datskati; to leak through a lorge orifice; to leak rapidly or entirely away.

ki cla tsó pe, $v$., fir. datsope; to kiss.-makidatsope, I kiss. da. kidatsope, you kiss. See ikida. tsope.

ki da tsí ki, $v$. t., intensive form of clatsuki.

ki da wó ki, same as kidamoki. ki de, verbal root; push; trans. fix, impale.

ki dé, $r$. $i$, ? fri. de; to fly.

ti dé ali de, r. t., comp. of kide and akde; to $\mathrm{Hly}$ off with; to bear off flying, as an eagle with its pres.

ki dé e, $v$. i., same as kide; to Hy.

li dé sa, $r$. i., intensive form of dièsa.

ki dě sá dsi, $v$. t., fr. kidẹ̆i and adsi; to like very much; to love, but not dearly.

ki dé sa ke [kinesalie], $v . t$, $f r$ desilke; to destroy, exterminate, banish, anuul, abrogate; to cure a disease completely, etc.

ki de $\dot{s i,} v . t$.; to love; said of the affection existing between 


\section{kid}

.parent and child, husband and wife.

ki dě ta, v. $t$.; to fancy, to admire.

ki dĕ tá dsi, $v$. $t$., to admire, but not greatly.

kí di, v. t., ? fr. di; to search for any person or thing, to go for game, to pursue, to seek. kikidi is more commonly used.

kí di e, $v$.; to mount a horse; to ride on horseback.

kĭ di é, $v$. $i$.; to be greatly terrified.

ki dî ki, v. t., fr. diki; to strike repeatedl.s.

ki dli si, $v . i ., f r$. disii ; to dance.

ki lo pa hé ke, $v$. t., fr. dopaheke; to divide completely into two equal parts; dirided equally in two.

ki dó pa ke, $v$. t., synon. kidopaheke.

ki du é tsa pi ke, $v$. $t$., fr. due. tsapike; to divide into nine equal parts.

ki du há, imperative of kiduhe; arise; said if the person is recumbent, not sitting. See duha and duhe.

ki du ha ku té, $n ., a d v ., f r$. kiduha; early morning, time to rise.

ki du ha ku té du, $a d v ., f r$. kiduhakute; during the early morning.

ki dí he, $v$. $t$.; to arise from a recumbent posture; to lift out ot.

ki dú hi, $v$. $i$.; arisen; standing. ki dú hi ke, $v$. $t$.; to cause or assist to arise from a recumbent posture.

ki dí lia, $v_{\text {。 }}$. ; to spread out on the ground; to spread to dry; to spread bedding. kid

ki du liá dé, $v$. $t$.; to rake; to clean thoroughly by raking.

ki du liă de, $v$. t., intensive form of duliăde.

ki du lié mi, $v$. $i$., to settle down, as a river; to dry up ; to become shallow.

ki du lié se, $v$. $t$., fr. duliese; to tear to pieces.

ki du lié wi, same as kiduliemi. ki du lió lii, $v$., fr. duliolii; to break, or to be broken completels across.

ki du lió hi lie, v. t.; to cause to be completely broken.

ki du hó ki, v. t., fr. dulioki; to comb out, to comb completely or thoroughly.

ki dí lipi, v. t., fr. dulipi; to take down something that is hanging high.

ki du ká pi, $v$. t., fr. dukạpi ; to lacerate extensirely or severely.

ki du ki ti, $v$. t., irtensive of du. kiti.

ki du kú ti, v. t.; pluck out ex. tensively.

ki du mă lii ta, $v$. $i ., f r$. dumaliita ; to ride or move repeatedly and rapidly back and forth.

ki du mă lii ta-ti di é, $v$; t to run or ride back and forth, as is done when one man alove makes a war-signal.

kí lu mi $[+-\mathbf{w i}], v . t$. ; to count.

ki du mi di, $v$. $t$., fr. dumidi ; to twill thoroughly.

ki du mí lia [-wilia], intensive form of clumilia.

Li du sá, v. t., fr. dusa; to place in security, to store or put away with care.

ki du sî pi, v. t., fr. dusiipi ; to open widels or completely. 


\section{kid}

ki díl ske, $v . t$., fir duske; to open a door or lid widely.

ki du śú ki, $v$. t., fr. dusinki ; to wash entirely or thoroughly by rubbing.

ki du tá, $v$., fr. duta; to burst violentls, to fly to pieces.

ki du tạ pi, v. t., fr. dutạpi; to squeeze long and hard.

ki du tạ́ ti, $v$. t., intensive of dutati.

li dú ti, $v$. t., fir. duti ; to eat up); to devour, to eat all; sail also if you speak of eating an animal still living, conveying the illea that sou will both kill and eat.

ki du tó' ti, $v$. t., fr. duto'ti; to corer by sprinkling; to exhaust by drealging or sprinkling.

ki du tsá dat, $v$., fir. dutsada ; to slicle far or rapidly.

Li du tsá lia, r.t., fir. dutsạki; to dissever completely and repeat. edly.

Ki du tsá ti, fi. dutsati; to impale securely.

ki dú toe, $r$. t., fr.dutse; to take off under difficulties; to take and hold securels.

Li du tsí pi, $v$. t., fr. dutsipi ; to completely untie anything secured by hard and numerous knots.

lí du tsí si, $v$. t., fir. dutsisi ; to sprink back, to regain suddenly and completely the original posi. tion when released from a bend. ing pressure.

Li In tsi ti, $v$. t., fir. dutsiti; to raze to the ground, to completely destros a building.

ki du tskạ pi, $v$. $t$., fr. dutskạpi ; to pinch severely or repeatedly.

ki du tokir si, $v . t ., f r$. dutskiši;

\section{kih}

to wash thoroughly, to wash cleau; to wash all that is given to be washed.

ki du tskí ti, $v$. t., intensive form of dutskiti.

Ki du tslíu pi, v. t., fi. dutsku. $\mathrm{pi}$; to bend in sereral piaces; to fold repeatedly.

ki du tsú ki, v.t., fi. dutsuki; to knead the abdomen long and vigorousls.

lki dlu wă lii ta, $v$. $i$, same as kidlumaliita.

ki du wi di, v. t., same as kidumidi.

lii e, $v$. t.; to fear.

ki ha hé ta, $v$. t., intensive of ha. heta.

ki hă lipi, $v$. i., fr. halipi; to sueeze repeatedly.

ki hă lipi lie, $v$.t.; to cause to sneeze hard or repeatedly.

ki ha liá' ti lie, v. t., fi. haka' tike; to completely and suddenly arrest progress.

lai há lạ tsi, $v, t$., fr. hakạtsi; to butcher completels, to cut up all the meat killed.

lí ha pá ke, v.t., fir bapake; to reuder very cold, or cold throughout; chilled, frozen.

ki hạ' pé sa du i, $v$. i., intensive form of ha'pesadui.

ki hạ' pé se, $v$. i., fir hạ'pesio; completely dark.

li hạ' pé se ke, $v$. $t$.; to completely exclude light.

lii ha ir si, $v$. $i, f r$ has̉isii ; to smart severely.

ki ha sir si lae, $v$. $t$; to cause to smart extensively or severely.

ki ha tsí te, $v$. $t$, intensive form of hatsite.

ki hă tská du i, v. $i$, fr. hatskadui; increasing rapidly in length. 


\section{kih}

ki hă tski ke, $v$. $t$; t to lengthen rapidly and greatly; greatly lengthened.

ki hi ke, $v ., f r$. híke; entirely drunk up.

ki hi sá dsi, $v . i ., f r$ his̉adsi ; to be completely reddish.

ki hi sá dsi ke, $v$. $t$.; to dye throughout of a dull red color.

ki hr si ke, $v$. $t$., fr. disike; to dye red; to dre the entire of anything red.

ki hi si sá du i, $v$. t., intensive of hisisisadui.

ki hi si si lie, $v$. $t$.; to cause to assume a reddish hue rapidly or throughout.

ki hi tá du i, $v$. $i$., fr. hitadui ; rapidly increasing in speed.

ki hi ta ke, $v$. t., frr. hitake; to accelerate motion greatly ; to increase the speed of a number of objects.

ki ho' pá du i, $v$. i., intensive form of ho'padui ; more common. ly used than the simple form.

ki ho bá se, $v$. $t$., fr. hopạse; to horrify; to horrify all.

ki hó' pi ke, $v$. $t$., fr. ho’pike; to riddle, to perforate in many places.

ki hí, $v$. t., comp. of ki and hu; to come with a load; to come bearing on the back.

ki hú a, $v . i ., f r$. hua; to cough repeatedly or severely.

ki hí a ke, $v$. $t$.; to cause to cough repeatedly.

ki lia, $n$.; the paunch, the stom. ach or stomachs of an animal.

ki lia a du pi dlă lipa, $n$., $f r$. kilia, adu, and pidalipa; the ru. men or first stomach of a ruminant.

ki liă da lii ke, $v$. t., fr. liada-

\section{kili}

liike; to starre completely, to make rery lean; to make a num. ber lean.

ki liă da lií ksaa ke, $v$. $t$., intensive form of hădaliikșake.

ki lia liá du i, $v . i$., fr. baliadui; becoming completely rough.

ki liă lii, $v . i ., f r$. lialii; to be entirely or completely striped.

ki liắ lii ke, $v$. $t$.; to cover with parallel bands; completely striped.

ki lia liú a ke, $v$. $t$, intensive of laliuake.

Li lia lái du i, $v$. $t$.; used the same as hakadui, but more commonly; said of a bealing sore, etc.

ki liă ka hé ta, $v$. i., intensive form of liakabeta.

ki liǵ ka lie, $v$. $t$., fr. liakake; to render a large surface itchy.

ki lia kú pa du i, $v$. $i$; becom. ing extensively furrowed.

ki lia kíl pi, $v$. $i ., f r$. liakupi ; extensively furrowed, furrowed over the entire surfase.

ki lia kú pi ke, $v$. $t$.; to mark the entire surface with furrows; completely furrowed.

ki liá ma dsi ke, $v$. $t$., fr. liamadsi ; to cause to appear much branched; to depict as very branching.

ki liár mi ke, v. $t$., fr. liamike; to make entirely diverging or scattering.

ki liá pa dui, $v$. $i$., fr. liapadui ; wearing thin throughont, or in numerons places.

ki liạ pạ ti, $v$. $i$, intensive of liạpaii.

ki liạ pá ti he, $v . i$.; to eat to complete satiety. 


\section{diili}

ki liạ pạ ti ksa, $v$. $i$; synon. with liapatikșa.

ki liạ pạ ti kisa ke, $v$. $t$; ; to gorge, to glut; to feed a number of persons to excess.

lii liạ pi he, $v$. $t . f r$. liạpihe ; to lose hopelessly ; to lose all.

ki há pi ke, $v$. $t$., fri liapike; to scrape or wear thin throughout.

lii liạ' pi ke, $v . t$. ; hopelessly lost; all lost.

ki lia' pi ksa. See liapikisa.

li liạ pi kia, ssynon. with liạpikisa.

li liá pi kisa ke, $v$. t.; to scrape, wear, or rub to thinness the entire of a skin or other such arti. cle.

ki liž Imtạ ki, $f r$. liatatạki, and nearly or quite ssnonymous.

lí liă ta tạ ki lie, intensice form of liatatạkike.

lii liá tsa, n., fri. kilia and itsa, lit., They Refused the Punneh; the Crow Indians. Lewis and Clarke spell this "kee-heet-sas" on their map, and speak of a portion of the Crows as "Paunch Indians". (See Lewis and Clarke, p. 96). For the origin of this name see a preceding page of this work.

li liá wi ke, same as kiliamike.

li lié mi ke, $v$. t., intensive of liemike, but more commonly used.

ki lié mi kisa ke, $v$. $t$., fr. liemiksaa ; to cause to be coustantly very lonesome or melanchols; to make a number lonesome.

lii lié pi, $v$. $i$, , fr. liepi ; entirely shallow.

ki lié pi ke, $v$. t.; to make en. tirely shallow, to leare no deep part; dried or drained to shallowness.

\section{kii}

lii lié wi ke, same as kiliemike.

lii lii di ă du i, $v . i$, fr. liidia; becoming rapidly or extensively itchy or sensitive.

li lií di a lie, $v$.t.; to cause to be entirely or extensirely sensitive or itchy.

Li lii di ạ kisa, $v$. $i$; denoting itching, constant or excessive, orer the entire surface or afflicting a number.

lii lii di a kia lic, $v$. $t$; t to cause constant extensire itching, etc.

lii lii é lie, v. t., intensive of liieke.

lii lií pi, $v$. i., fir. lippi entirely wrinkled.

lii lií pi ke, $v$. $t$.; to make entirely wrinkled.

ki lió lia di ti, intensive (and common) form of liokaditi.

li lio pạ se, $v$. t., fr. liopạse; to occasion general terror.

ki lio pạsi ke, $v$. $t$.; to cause general or continued alarm.

ki lio ta ká dsi ke, $v$. $t ., f v$. iliotakadsi ; to change to a whitish color.

ki lio tạ ká du i, $v$, $i, f r$. ilio. tạkadui; whitening throughout.

ki lio tá ki lie, $v$. t., fr. iliotakike; to bleach uniformly throughout; to paint entirely white; whitened, bleached.

kí liu, mum. adj.; five.

ki liú a he, $v$. t.; to make fire; made into fire.

ki liú a he ke, $v$. $t$.; to divide into five parts ; divided into five parts.

ki liú a ke, $v$. t., synon. with ki. liuaheke.

ki ic tí a, $v . i ., f r$. ictia (intensive form). 


\section{kii}

ki ic ti á du i, $v$. $i$.; increasing rapidly or greatly.

ki ic tí a ke, v. t.; to cause to be enlarged greatly or throughout; to increase several objects.

ki i dlá mi ke [-nawi=], v. t., fr. idanike, and of similar mean. ing.

ki i clí a lii, $v . i ., f r$. idialii; to sigh repeatedly.

ki i di pá du i, $v$. $i$, fr. idipadui, and used synonymously.

ki i dr pi, $v$. i., intensive form of idipi.

ki i dř pi ke, $v . t ., f r$. idipike; to fatten rapidly; to fatten a number.

ki i di př ksa ke, $v$. $t$.; to make constantly fat.

ki i di tsi i sí a ke, v. t. See iditsiisiake.

ki i dr tsi ke, $v$. t., intensive of iditsike; nearly or quite similar in meaning to the simple form.

ki i di tsi tsa kí ke, $v$. $t$. See iditsitsakike.

ki i ló pa du ke, v. t., fr. ido. paduke; to change to the second order or position, to change from some other position and place second.

ki i dó pa ke, v. t.; to make second; to change to second.

ki i há ke, $v . t ., f r$. ihake; to make entirely different, to change all attributes.

ki i liá tsa ki, v. $i$, fr. iliatsaki; stained extensively with dirt.

ki i liá tsa ki ke, $v$. $t$.; to stain completely or extensively with dirt.

ki i lió a de, $v$. $i$., $f r$. ilioade; to be sererely sick; said, too, of a number suffering from an epidemic.

\section{kii}

ki i lió a de ke, $v$. t.; to make sick; sickened.

ki i ko ki, $v . t ., f r$. ikoki; to hang up high or securely.

ki i liú pa, v. t.,fr. ikupa; to accompany closely or continu. ally.

ki i kú' pa, v. t., intensive form of ikúpa.

ki i kú, pa dsi, v. t., intensive of ikúpadsi.

ki i ku' pá dsi ke, $v$. $t$.; to cause to dislike.

ki i kú' pa ke, v. t.; to cause to hate.

ki i mă lipi, $v$. $i$., fr. imalipi ; set completely.

ki i mi a, $v . i ., f r$. imia; to cry long or frequently; to mouru by crying.

ki 1 mi a ke, $v . t$; to cause to cry long, etc.

ki l psạ ki, $v . t$., fr. ipsaaki ; to conceal or screen completely.

ki i sí a, v. i., intensive form of isisia.

ki i si á du i, $v . i$.; deteriorating greatls.

ki i si á du i lie, $v$. $t$.; to cause a rapid progressive deterioration.

ki i sí a ke, v. $t$.; to make bad, to change from good to bad; greatly damaged; all damaged.

ki i tó di ke, intensive of itodike.

ki i tó pa du ke, \} v.t.; to place ki i tó pa ke, f fourth; to cause to be fourth. See itopake.

ki i tsí i ke, $v$. $t$., fr. itsiike; to strengthen completely.

ki í tsi laa lke, $v$. t., fr. itsika; to cause to be first; placed first.

ki i tsí tsi, $v$. $i$, intensive of itsitsi ; gleaming continuously. 


\section{kii}

ki i tsí tsi ke, $v . t$.; to cause to gleam.

ki i tski ke, $v$. $t ., f r$. itski; to make large enough.

ki i tú di, $v$. $i ., f r$ itudi; snppurating extensicely ; said of large or numerous abscesses.

kí i tíl di ke, $r . t$.; to cause extensive suppuration.

ki kạ da mi, v. t., fi. kạdami ; to remember after haring long forgotten; to remember completely.

ki ka dạ́ tsi ke, $v$. $t$., fr. kadạtsi ; to cause to be willing.

lai ka dé, v. t., intensive of kade; - to vomit all up.

ki ka dé ke, $v . t$.; to cause to vomit.

ki kai di, $v$. $t$., fr. kadi; to beg repeatedly, to importune; to beg all away.

ki ka dí sta, $v$. i., intensive of kadista.

ki ka di stá du i, $v$. $i . ;$ dwindling rapidly.

ki ka dí sta ke, $v$. $t$.; synon. with kadistake, and more com. monly used.

ki ka dri tska, $v$. $i$, fr. kaditska; to glisten continuously or over an extensire surface.

ki ka dir tska ke, $v$. $t$.; to cause to glisten; made to glisten.

ki ka dí toka pa, $r$. $i, f i$. kaditskapa ; to adhere firmly over a large surface.

ki lia dir tska pa ke, $v$. $t$.; to cause to adhere, etc.

ki ká dse, intensive of kadse.

ki ka ké' ki, $v$. $i$., fr. kake'ki; to make a continuous rattling noise.

ki ká ki, v. t.; to sew; to join by sewing.

\section{kik}

ki ka kí liá du i, $v$. $i$, fr. kakilii ; assuming a circular form.

ki lia ki lii ke, $v$. $t$.; to cause to be entirely or permanently circular.

ki liạ ta ki, $v$.t.; to turn com pletels inside out.

ki ka tí he, $v$. $t$., intensive of ka. tihe.

ki ka tí ke, $v$. i., fr. katike; to pour all from one vessel to another, to empty one vessel into enother or others.

ki kạ́ tsi, $v$. i., fir kạtsi; completely cooled; said, too, of a number of objects which hare been cooled or extinguished.

ki lia tsi lie, $v$. $t$. ; to cool completely; to cool a number.

ki ka tsú ka, $v$. $i$, intensive of katsuka.

ki ka tsí ka lie, $v . t$; to cause to be swelled and hardened.

ki ka ú sta du i, $v$. $i$., fr. kaustadui; decreasing greatly and rapidly in number or quantity.

ki ka ú sta ke, nearly synonymons with kaustake, but more commonly used.

ki kæ, $v . t$; to resemble.

ki ké, $v$. t., fr. ke; to scratch back and forth; to scratch repeatedly or severel.y.

ki ki di, $v$. t., fr. kidi; to hunt, to seek and pursue.

ki ki liú a he ke, $v$. $t$., fr. kilinaheke; to divide completely into fire equal parts; divided into five.

ki ki liú a ke, $v$. t.; to cause to be divided into five parts; divided by fire.

ki ki ski, $v . t$.; to determine quantity or quality in any way; to taste, measure, or gauge with 


\section{kik}

a view to determining quality or quantity; to sound a person's feelings or opinions.

ki kó mi [wi], sỹnon. with komi.

ki kó mi he, $r$. t., fr. komihe; to complete or finish perfectly; to finish all.

ki kó mi le, $v$.t.; to cause to be concluded, terminated, or exhausted; concluded, finished, etc.

ki kí wi he, same as kikomihe.

ki kó wi ke, same as kikomike.

kir ksa, imperative of kiksie.

ki kje, $v$. $t$.; to arrange; to repair, to mend, to "fix".

ki kír, v. t., fr. ku ; to gire back, to restore.

ki kú a, v.t.; to listen; to hear; to pay attention to.

ki ku há, $v$. $t$.; to send for a person, to invite.

ki ma á ni, $v$. i., fr. maazi ; to be full to overflowing; to be all tull-if a number of ressels are referred to.

ki ma á zi ke, v.t.; to cause to be filled.

ki má di he, $v$. $t$., fr. madihe; to cook all the food on hand; to complete the cooking.

ki ma du hị pa ke, $v$. $t$., fr. maduliapake; to set beastly drunk ; to set all drunk.

ki ma du híá du i, $v, i ., f r$. madulitadui; becoming vers foolish.

ki ma dú lita ke, $v$. $t$.; to make quite foolish.

ki mạk' i a, $v . t ., f r$. mạkia ; to fight; to battle.

ki mạk i ma ká da ha ti di $\mathbf{e}^{\prime \prime}, v . i$. ; synonymous with mạkimakadahatidie, but more commonly used.

\section{kió}

ki mạk se sá du i, $v$. $i$, used in nearly or quite the same sense as makisesiadui.

hi mạk sé se ke, $v$. $t$., fr. makseselie; to cause two things to resemble each other in every respect; to cause several things to resemble one another.

ki mạk sí a ka, $v$. $i$, fr. mạksiaka; to be of the same size in all dimensions.

Li mạk sí a ka ke, $v$. $t$; to cause two or more things to be of the same size in all their dimensions.

Ka má ku ke, $v$. $t$, intensive of makuke, and more commonly used.

ki mé [-we], v.t.; to tell, to relate; to diselose a secret.

ki mi á ti ke, $v$. $t$.; synonymous with miatike.

hi mi dé di, $v$. $t$., fr. midedi; to come in and sit down; to pay a long visit; to risit frequently.

ki mí di ke, $v$. $t$., fr. midike; to liquefy completely.

ki mi dú e, $v$. $i ., f r$. midue; to boil vigorously.

ki mi dú e ke, $v$. t., synonymous with midueke.

ki ó da pi, $v, t$., fr. odapi; to find all, to make a complete dis. covery.

ki $\mathbf{~ h i , ~} v$. t., intensive of ohi.

ki o hi ke, $v . t$.; to cause to be attached, to treat with kindness and foster attachment.

ki ó lia ta du i, $v$. $i$, f $r$. oliatadui; becoming white throughout.

ki ó lia ti, $v$. $i$., fr. oliati; to be entirely white or pale.

ki ó lia ti ke, $v$. $t$.; to render entirely pale. 


\section{kió}

ki ó kạ ta, v. t., fr. okạta; to put all on, to dress completely.

ki o ki, v. t., fr. oki ; to hold firmly; to hold all.

Li o ti, $v$. t., fr. oti ; to be cooked or ripened throughout; all rip. ened.

ki o ti lie, $v$.t.; to cause to be entirely ripened.

ki ó tslia mi [-wi], $v$. i., intensive of otsliami.

ki ó ze, v. t., fi. oze; to plant all the seed or all of a field, to finish planting.

li pá, v. t., fr. pa; to powder or grind completely.

hí pa dó pa du i, $v$. $i$, fr. pado. padui ; becoming rapidly low in stature.

li i pa áo pi ke, $v$. t.; to shorten in stature.

ki pă du i ke, $v . t ., f r$. paduike; to diminish in length ; short. ened.

lii pá hi, v. i., fr. pahi; to sing loudly or continuousle; to sing a song.

li pá lia du i, $v . i ., f r$ paliadui; becoming extensively chafed.

ki păi litu e, $v$. $t$; ; to scratch or lub with the finger-tips or knuckles; to rub the hair loose with the fingers; to rub the eyes in sleepiness.

ki pá liu e, v.t., fr. paliue; to spill all out, to empty.

ki par ka de, $v$. t., fr.pakade; to stick in numerous places.

ki pa kạ pi, $v$. i., frr. pakạpi ; to be torn extensively or sererely.

ki pá ki di, v. t., fr. pạkidi; to push hard; to shove completely away.

Li pạ ki si, $v . t$., fr. pạkisii; to rub back and forth as in scour.

\section{kip}

ing, or as in drying with a towel; to dry by rubbing.

ki pa mi tsi [-wi-], $v, t ., f i$. pamitsi ; to cut all up finely.

ki pa mú dsi [-wu-], $v . t ., f r$. pamudsi ; to roll up completely, to make an entire piece into a roll.

ki pa sá ki, $v$. $t$., fr. paśaki ; to engirdle completely; to put on a belt outside of the robe and all the clothing.

lai pa skú, $r$. t., fr. pasku; to shove completely through.

ki pa tạ́ ki, $v$. t., fr. patạki ; to shut as a door or a box-lid, to close up as a book, etc.-mide kipatạk, shut the door.

ki pă té, v. t., fir. păte; to turn completely over.

ki pạ ti, $v$. i., fir pạti; to fall from a great height.

ki pạ ti he, $v$. $t$; to throw down from a great height.

li pạ ti ke, $v$. $t$; to cause to fall from a great height; to shoot a bird sitting in a tree-top and, thereby, cause it to fall to the ground.

ki pa tó' ti, $v$. t., fr. pato'ti ; to shake repeatedly or vigorously.

ki pa tsá ti, $v$. t., fr. patsati; to puncture repeatedly.

ki pa tskú pi, v. t., fr. patsku. pi ; to fold several times; to fold into a small bundle.

lii pa tskú pi ke, v.t.; to cause to fold up.

ki pé, $v$. t., fr.pe; to swallow all, to derour completely.

ki pě, $v . t$., fr. pe; to triturate finels; same as kipa.

ki pliú ti, $v$. $t$., fr. pliuti; to squeeze completely out; to pro- 


\section{kip}

trude by squeezing or pressing; to eject metallic cartridges.

ki pi, $v, t ., f r . p i$; to deck or tattoo the body extensively.

hi pur di e ke, $v$. $t$., fir pidie; to flute or ruffle, to ornament with ruffles.

ki pkiri, di, v. t., intensive of pạkidi.

ki plai ti, $v . t ., f r . p k i t i$; to iron clothes; to smooth completely out.

ki pó a du i, $v$. t., fr. poadui ; to make completel. globular.

ki pó pi, $v . i$; ; worn out, as old clothing.

ki psiú ki, $v$. $i ., f r$ p psuki; to belch; to bel ch repeatedly; much less used than the simple form.

Li psír ti, v. t., fr. psinti; to dislocate, to put out of joint.

ki ptsú ti, $v . t ., f r$. ptsuti; to thrust forward.- - deši [nesii] kiptsuti, to stick out the tongue.

ki pu á du i, $v$. i., fr. pnadui; becoming rapidly or extensively swollen.

ki pú a ke, $v . t$., fr. puake; to cause to be greatly or extensirely swollen.

Ki pú dsi, $v$. $t$., fr. pudsi; to mark, sew or wrap extensively or completely.

ki pú dsi ke, $v$. $t$.; to cause to be finely marked or wrapped.

ki pú lii, $v$. i., intensive of pulii ; to foam.

ki pír lii ke, v.t.; to cause to foam greatly; to cover with foam.

Ki pú zi ke, $v . t$., fr. puzike; to cover with spots or figures.

ki sa pu a hé ke, v. t., fr. sapuaheke; to divide into seren equal parts.

\section{kit}

Li sá pu a lie, divided into seren parts.

lki sa sín lii lie, $v . t$; to cause to be completely dull; dulled throughout.

ki si di ke, $v$. t., fr. sidike; to render tawny; to sinoke a skin until it assumes a tawny hue.

ki i i di si, $v . i$, intensive of sidisi. ki si dri si ke, $v$. $t$; to cause to hasten.

Li si líi a lae, v. t., fr.sikia; to canse to curl or tangle; tangled.

ki.si ki he, $v$. t., intensive of sikihe.

Ki si pi sá dsi ke, v. t.; to dye blackish.

ki si pi sál du i, v. $i$, d darken. ing throughout.

ki sí pi sa lie, $v$. $t$., fr. sipisiabe; to dye black uniformly through. ont.

kir ski, $v . t$.; synonymous witb kikiski, but rarely used.

ki só ki ke, $v$. t., fr. șohi; to widen, to make broad or blunt.

ki su á du i, $v$. $i, f r$. s̉ua; decreasing in speed.

ki sir a ke, $v$.t.; to cause to be slow, to change from a rapid to a slow motion.

ki tá, intensive of ta; killed.

Li tá di, $v . t ., f r$. tadi; to cross completely, as when a large party with all its effects crosses a stream.

ki ta hé, $v$. $t$, fr. tahe; to murder, to slaughter.

ki ta mú e, v. t., fr. tamue; to ring long and loudly.

ki ta múr hi lie, $v$. $t$., fr. tamulii; to cause to be minute, to change from coarse to fine.

ki tạ tsá du i, v. $i$., fr. tạtsadui ; thickening throughout. 
kit

ki tạ tsi ke, v. t.; to make thick in erery part; to thicken all.

ki té, $v . i ., f r$. te; to be all dead; said if a number of individuals are referred to.

ki te, rerbal root; clear off, make smooth '(share, pluck, etc.).

ki ti, verbal root; same as kite.

ki tr di e, $v . i$., $f r$. tidie; to run far or long; to run awas.

ki ti di é lie, $v$.t.; to cause to run far.

Li ti pi ă tsa ki, $v$. $i$, fr. tipia. tsaki; completely soiled with mud.

ki ti pi ă tsa ki ke, $v$.t.; to soil completely with mud.

ki ti sa ke, $v$. $t$., fr. tisa; to cause to be distant, to remore far away.

ki tr tsă du i, $v . i ., f r$. titsadui ; thickening rapidly or along the entire length.

lii tr tsi ke, $v$. $i$., fr. titsike; to thicken thronghout.

ki to ha dsá du i, $v$. $i$, f $i$. tohadsadui; becoming bluish throughout.

ki to há dsi ke, $v$. $t$, fr. tohadsike; to dye or color bluish thronghout.

ki to há du i, $v$. $i$.; assuming a pure hlue color throughout.

ki tó hi ke, $v$. $t$., fr. tolike; to dye or color all a pure blue.

ki tó ki si ke, $v$. $t$, intensive of tohisike.

Li tó pa he, $v$. $t$., fr. topahe; to dicide into four completely.

ki to pa hé ke, $v$. $t$., fr. topaheke; to divide completely into four equal parts; disided into four equal parts.

ki tó pa ke, $v$. $t$.; synonymous with kitopaheke.

\section{kit}

ki tsă da ke, $v$. t., intensive of tsadake.

ki tsa dáa tsa ki ke, $v$. $t$., $f r$. tsadatsalike; to soil all over with grease.

ki tsa ká dsi ke, $v$. t., fr. tsakadsi; to improve all moderately.

li tsa kí ke, $v$. $t$., fr. tsạkike; to completely cure, improve, or mend; mended, restored, perfected.

lii tsa mé a te, $v . i$, fr. tsameate; to perspire freely, or from the whole surface.

lí tsa mé he, $v$. $t$., fr. tsamehe; to heat thoroughly.

ki tsa mé lie, heated throughout; changed from very cold to very hot.

ki tsa mú tsa du i, $v$. $i$. ; straightening along the entire length.

lii tsa mú tsi ke, $v$. $t$., fr. tsamutsike; to straighten completely.

ki tsá ti ke, v. t., fr. tsati; to render smooth and glossy; to oil, polish, or varnish.

ki tsa tsú lii lae, $v$. $t$., fr. tsatsukilie; to render completely hard by drying, baking, or oth. erwise.

ki tsi dá dsi ke, $v$. $t$., $f r$. tsida. dsi; to dye of a color allied to yellow.

ki tsi dá du i, $v$. $i$.; becoming sellow throughout.

ki tsi dí e ke, $v$. $t$., fr. tsidie; to cause to be cold; reduced in temperature.

lai tsí di ke, $v . t ., f r$. tsidike; dsed all sellow.

ki tsi kó a, $v . i ., f r$. tsikoa ; thor. oughly sweet. 


\section{kit}

ki isi lio á du i, $v$. $i$; becoming sweet throughout.

ki tsi kó a ke, $v$.t.; to make entirely or thoroughly sweet.

ki Usi pi, v. i., fi. tsipi; to sink entirely, to be lost completely in the water.

ki ts.î pi ke, $v$. $t$., fr. tsipike; to cause to sink totally.

ki đor pri ti, $v$. i., intensive form of tsipiti.

Li tsi pli ti lie, $v$. $t$; to place the whole in a condition to sink; to upset all on the water.

ki tso kéa du i, $v . i$., fr. tsokadui; becoming entirely bard.

ki tsé ki, $v$. $i$, intensive of tsoki.

ki Isó ki ke, $v$. t.; to make en. tirely or permauently hard.

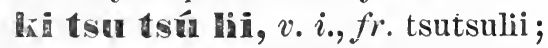
to make a continuous rattling or stamping noise.

Li tsú tsa ti, $v$. $i ., f r$. tsutsuti; to be entirely smooth ; uniformly soft.

ki tsí tsu ti ke, $v . t$; to make entirely or uniformly smooth.

ki u á, $v . t$., fr. uá; to enry continually or maliciously.

ki ú a he, v. t., intensive of uahe.

ki u ă lipi, $v . t ., f r$. ualipi; to smash to pieces by shooting.

Ki U ă ti, $v . t$., fr. uati; to ridicule continuously or sererely.

ló u dsá du i, $v$. $i$, fr. udsadui; becoming uniformly dry.

ki ú dsi, $v$. $i ., f r$. udsi; to be dried completely.

ki ú dsi ke, $v$. $t$.; to dry completely.

ki íl zi a, v. t., intensive of uzia.

lii Wé, $v . t$.; to tell; same as kime.

kó a, prep.; at; in; suffixed to nouns to form adverbs.

\section{líxa}

kó e, $v$. $i$; to leave, depart, go from.-makóemits, I will learea common equivalent for good. bye.

Ló ha ti, $n$.; corn, maize.

Kó ha ti a, $n$. ; a corn-stalk, the stalk or the entire plant.

kó ha ti i si, $n$., fir. kohati and iši ; a bag for containing corn. Caches are sometimes called kohatiisi.

Lío ha ti pi, $n$. ; coarse corn. meal, such as is made in a wooden mortar.

kó ha ti tạ pa, $n$. (tạpa, soft); flour.

ko ká, v. t.; to cease to act, to stop, to discontinue; commonly used imperatively.-kokạts, it is done.

Kó mi, $v . i$; to be finished, ex. hausted, expended, or completed.

Kó mi he, $v . t$.; to finish, to ex. haust, to cómplete.

Lí wi, a common pronunciation of komi.

kó wi he, same as komihe.

$\mathbf{k} \mathbf{z} \mathbf{i}, v . i$; to make a whistling sound.

ksa, an adverbial suffix, denoting that an action or quality is const an t, habitual, or excessive. See $\uparrow \boldsymbol{\uparrow} 163$ and 231.

kta dé, $v . t$.; to secure or join with nails or rivets.

Isu, v. t.; to give, to present.

ku, demonst. pronoun, referring to something pointed out, obvious or previously described; that, that one. Most of the following words beginning with ' $k u$ ' are more or less directly derived from this pronoun.

kin a, adv.; in that way or place, just so. 


\section{kúa}

líu a du, adv., fr. ku and adu ; in that very place, right there.

kú a ru, same as kuadu.

kí dsi, $v$. $t$.; to take back something giren.

kú i sa, adj., adr., fr. ku and is̉a; like that, just like that.

ku i són dsi, adj., adv., fro. kuis̀a and adsi; much like that, resembling that closely.

ku i sá dsi ke, $v$. $t$.; to cause to resemble imperfectly something previously mentioned or pointed out.

kú i sa ke, $v$. t., frr. kuis̀a; to cause to resemble something previously demonstated or defined.

Líi plie da, adv.; opposite or facing something previously named or pointed out.

kí pi, $v . i$, adj.; to smell like, to have the same odor as something previously mentioned and compared.

kiú ta, adv., fr. ku ard ta; thereat, therein.

kú ta pa, interrog. pron. or sentence, $f r$. ku and tapa; what is that, what is the nature of the thing named or pointed out.

kú ti, adj.; dirty; seedy, shabby; said of old clothes, etc.

kuts, $v$.; here, take it. This rord is perhaps a form of the verb $k u$, and mas mean "it is given to you"; but is used when commanding a person to accept something offered.

kí tsa ki, pron. (?), fr. ku and tsaki; that one alone, that by itself.

kí tski, $v$. $i$; to be like, to accord; to be measured, regulated, or shaped according to a stiud. ard or pattern. maa

I.

1. Words heard to begin with the sound of 1 may be found under d. See $\uparrow \uparrow 6,20$, and 22 .

\section{I1.}

m, a common contracted form of the simple personal pronouns of the first person. ( $(\pi) 105$, 112).

ma, pers. pron., 1st pers., sing. and plur., simple, incorporated, nominative and possessice; I; we ; my ; our. (ब $\Upsilon$ I 58,81 , and $105-108$, inclusive.)

ma, a prefix to verbs of all classes forming nouns; a prefix to nouus slightly limiting their meanings; to be carefully distinguished from the pronoun ' ma', which is often used as the first syllable of a word. ( $\uparrow ~ \uparrow 53-56)$.

ma', $n$. ; snow.

ma á, $n ., f r$. a ; the entire plant; the body or chief portion of a plant or tree as distinguished from any of its parts.

ma ă da lia, $n$., fro adalia ; coffee in the grain ; parched coffee; but not the infusion or decoction. See midišipișa.

ma a dạ́ lipi, n., fr. adạlipi ; a single part or portion.

ma ă da í du ti, synonymous with adaiduti.

ma ă da í ki du lio tai, $n ., f r$. ăda and ikidulioki; a comb.

ma a dé, n., fr. adle; a warm season, a sultry time.

haa a du ă dă pa pi, $n$., $f r$. 


\section{maă}

adapapi; a. scorched or sunburnt spot.

ma ă du hi da", $n ., f r$. aduhida; anything new or recently made; an unworn garment.

ma a lu hó' pi, sáme as adu. hopi.

ma a du lia kú pi, $n ., f r$. aduliakupi; a crease or groove in anything.

ma a du liạ pi, n., fr. aduliạpi ; a bed, any one's bed; commonly applied to a permanent bed with bedstead.

ma a du lié pi, n., fr. aduliepi; a shallow spot.

ma a du i dă ki sa, $n ., f r$. aduidakisia; a left-handed person.

ma a du i dî tsi, n., fr. aduiditsi ; a particular odor.

ma a du i dí tsi ì sín a. See aduiditsiisia.

ma a du i dǐ tsi tsạ" Ari. See aduiditsitsạki.

ma a du i sí a, $n ., f r$. aduisia ; a worthless person; an inferior thing.

ma a du í ti pe, $n$.; a fall-trap. ma a du kí a de tsi, $f r$. adukíadetsi ; a brave man.

ma a du ki du śŕ, $n ., f r$. adukidusa ; a place where anything may be stored, or where only certain things are stored which it is not necessary to specify.

ma a dú ó ki pa di, n., fr. okipadi ; a scion, a sapling.

ma a lii dú lia, $n$.; large beads, such as are used in necklaces; a necklace of such beads.

ma ạ ka kạ si, $n .$, fr. ạkakạsi ; a writing, an inscription.

ma a ku ki kjse, n., fr. akukiks̉e; one who arranges or meuds

\section{mnád}

something understood or not specified.

ma a ku má di he, n., fr. akumadihe; a cook, one who cooks anything.

ma á pi, $n$.; a necklace.

ma d́ po kisa, $n$.; a house-fly.

ma á puzi,n., fr. puzi ; a meatfly.

ma a ṡ́r di, $n ., f r$. as̉adi ; a stolen article; a theft.

ma á tsí, n., lit., yellow trec; pine.

ma á $z i, v$. $i$; to be full.

ma a zi he, $v$. $t$.; to fill full.

ma á zi ke, $v$. $t$.; to cause to be full ; filled.

ma bú a, same as mamua.

má da $[-\mathbf{r a}], n$.; winter ; a year. má da da lia, $n .$, fr. mada and daka; snow-bird, Lapland bunting (Plectrophanes sp.).

má da du [-ru], adv., fr. mada; during the winter.

má da duk [-ruk], $n ., a d v ., f r$. mada; next winter; during next winter.

ma dạ lia pi, $n$.; bread.

ma dạ lia pi hó’ pi, n., fr. ho'pi ; light bread.

ma dạ lia pín ki da ka pú si, $n$.; saleratus or other learening material. See kidaka. pusii.

ma dạ lia pi tso" ki, n.,fr. tsoki ; hard-bread, crackers.

ma da ka př lii, $n ., f r$. dăkapi. lii ; a flag, a banner.

ma lá ki, $v$. ; to pajnt, to draw; to ornament with drawings.

ma da lió é [malakoe, balakoe, banakoe], $n ., f r$. dakoe or idakoe; my friend, $m y$ com. rade.

má da se du, $n_{.}, a d v ., f r$. mada 


\section{mad}

and sedu; last winter; during last winter.

ma dạ ski he [-lạ-], n.; unripe corn prepared for keeping.

ma dá' ti, $n$. ; my brother-inlaw. See idáti.

má di, adj.; cooked.

ma dí di, n.; meat dried in broad thin lasers.

ma di é [badiets], $v . t$. ; I think, I suppose, I beliere. See idie.

má di he, v.t.; to cook, to prepare food.

ma dYr sii, $n ., f r$. disis ; a dance; synonymous with makidisi.

ma dr si, $n$. ; my son. See idisisi. ma dó lia, $n$.; gypsum. These Indians burn gypsum and use it as a pigment.

ma dó ka, n.; an elk.

ma dó lia o dă" hpi, $n$. ; àn elk-skin.

ma dó ti ka de, $n$.; a gall or swelling on a plant caused by an insect laying its egg.

ma du hạ pa, adj.; crazy, insane; drunk.

ma du liạ pa dsi, adj.; appearing as if drunk; rcting crazily.

ma du liạ pá du i, $v$. $i$; becoming drunk.

ma du liạ pa ke, $v$. $t$.; to cause to be crazy ; to set drunk.

ma dú lii, $n$. ; ice.

ma du lii ic' pu, $n .$, fr. madulii and icpu ; an icicle.

ma dú lita, $n$.; a foolish or silly person, $a$ fool; a harlot.

ma dú lita, adj.; foolisb, silly. ma du litá du i, $n$.; becoming foolish.

ma dú lita. ke, $v$. $t$.; to cause to be foolish.

\section{máh}

ma du skạ pi, $n$. ; urethritis. ma dú ti [maruti], $n ., f r$. duti ; food, particularly solid food. ma du" ti a du ki du sán, $n$; a place for storing food.

ma du ti ki dr ti, $v$. $i$.; to be surfeited, to be sick from eat. ing.

má e, n., fir. e ; private property, anything retained in possession. See itamae.

ma ๕ pa lia, $n ., f r$. maepe and aka; the club or pestle used with the wooden mortar for grinding corn, meat, etc.; more commonly pronounced měpaka.

ma $\check{~ p e, ~} n$., frr. ěpe; a wooden mortar used by these Indians for pounding corn, dried meat, and other articles of food.

ma é tsi [baetsi], $n$.; a knife. ma é tsi-a du ki da kíti, $n$.; a pocket-knife.

ma é tsi a zis, $n$. See Local Names.

ma é tsi ha" tski, n., lit., Long Knives; synonymous with maetsiictia, which is the more com. mon expression.

ma é twi ic ti" a, n., lit., Big Knives; the inhabitants of the United States. This word is probably trauslated from the language of some tribe farther east.

ma é tsi r s̀i, $n$., fr. maetsi and isii ; a knife-case.

má ha, $n$. ; a swamp ; a spring. The springs of the Hidatsa country are swampy, not clear and bubbling; hence, the double meaning of this word.

ma ha ka kir siki, $n$.; meat cut in long strips and dried.

má he, $r$. $t$. Sce maihe. 


\section{maln}

ma Ini si, n., fr. hisi ; the bullberry or buffalo-berry.

ma hí si a, $n$.; the bull-berry tree, Shepherdia argentea.

ma hó pa, n., same as mahupa, which is more common.

ma ho pá, n., fir. hopa; medicine; a charm, a spell.

ma lno pái mi a, n., same as ma. hopamiis.

ma ho pá mi a i ta ma" tsu, n. (matsu, cherry); the fruit of the Virginia creeper. See dókidaliitamatsu.

\section{ma ho pá mi a i ta ma" tsu}

a, $n$.; the Virginia creeper, $A m$. pelopsis.

ma ho pa mí is [-wiìs], $n$; a fabulous old woman (some think there are more than one), who $d$ wells in the woods and delights in doing evil. She is supposed to strangle such children as, through parental ignorance or carelessness, are smothered in bed.

ma hí pa, $n$. ; the stem or handle of anything; a corn-cob.

ma liá lia, $n ., f r$ lialia; Cynoglossum Morrisonii.

ma liá ka, n.,fr. liaka; smallpox.

má lio, $n ., f r$. lio or ilio; $\mathrm{my}$ bods.

ma lió ki, v. t.; I row. - See dalioki.

ma liú a lia, n., fr. iliualia; my knee.

ma lír lii sa, $n$; tree-willow, Salix lucida.

ma i a ka kạ si, n., fr. ạkakạsi ; a pen or peucil.

ma í a pạ ti, n.. same as iạpạti. ma ic tí a, $n ., f r$ ictia; a boy or girl nearly or quite full grown;

\section{mai}

said in contradistiuction to makadista.

ma i dăk tšá da ke, $n ., f r$. daktsadake; skates.

má $\mathbf{i}$ dăk u dsi, $n$., fr. diıliudsi; a swing; a swinging cratle, such as these Indians use to rock their children.

ma i da tska ti, $n .$, fr. datskati ; a syringe.

nna i di ké di ks̀a, $n$.; straps or bauds for supporting the leggings; garters.

ma i dí Isi, $n ., f r$. iditsi ; material for scenting.

ma í lu tsa da, $n ., f r$. dutsada; a sled.

ma i dí Isi, $n$. ; syuonymous with idutsi ; a fork of any description.

ma í du tskạ pi, n., fr. dutskạpi ; a pincers; a clothes-pin. In the latter sense, maitulii-idutskạpi is preferable.

ma í du tsku pi, $n$. See muaidutskupi.

ma i há, $n ., f r$. iha; an enemy, an inimical tribe.

ma i há li, n., fr. ihadi ; food set out, a meal, a feast.

ma i há lipi, $n .$, fr. halipi ; an errhiue, a plant obtained by these Indians on the prairies, powlered and used as snuff in cases of catarrh; uame recently applied to snuff.

ma i há mi a, $n ., f r$. maiha and mia; a member of the Enemy. woman Band.

ma i há mi a ic lie, $n$.; tho Enemy-woman Band, one of the orders or degrees among the IIidatsa women.

ma i he, $v$. $t$.; to trs, to endearor.-mailse, he tries. ma- 
maí

dahe, you try. mamahe [ hets], I try. Possibly mahe is the true radical form, but it is nerer heard. ( $(T$ 199).

ma i hu [ba-, wa-], to trade, to buy. ( $(\boldsymbol{\Phi}$ 199).

ma i lia ka, n., fr. liaka-alluding to effects upon the skin; poison vines, Rhus toxicodendron, and Rhus radicans.

ma i ka dri tska pa, n., fr. kaditskapa; adhesive material, paste, mucilage.

ma i ka ti pe, n., fir. ikatipe; a button of any kind.

ma ki da ku di, n., fr. kidakudi ; a fin. The Hiclatsa commonly make fans from wings of birds.

ma i ki da ku dsi, n., fir. kidakudsi ; same as maidakudsi.

ma i li di ki. See makidiki, which is more commonly used.

ma i ki du lia di, $n ., f \circ$. kielu. liadi ; a rake.

ma i lei du lio lai, n.; synonymous with maadaikilulioki.

ma i ki lia, n., fr. ika; glass; a window.

ma i ki ló ki, n., fr. kikaki; threall.

ma i ki ki jki, n., fir kikiski; a weight; a measuring ressel.

ma i lí ku, n.; a spring. trap.

ma i ki ba ki ii, n., fir. kipạkisi ; a cloth for wiping or rubbing, a towel.

ma i ki pa ia ki, n., fir. kipasaki ; a belt worn ontsicle of all the clothing, around the robe or blanket.

ma í li pki ti, n., fr. kipkiti ; a sad.iron.

ma í ki tsa ti ke, n., fir. kitsa.

\section{mai}

tike; any material used in polishing.

ma i ki tso ki, $n ., f r$. kitsoki ; material used to render any thing hard, as starch.

ma l kta le, $n$.; a nail, peg, or spike, anything driven in for the purpose of securing.

ma i kí tski, n., fr. ikutski; ansthing copied or taken from some model or used as a modiel, a pattern for a garment, a model of an instrument or ntensil; sometimes applied to a measuring tape or stick.

nמa i kú tski ksa, n.,fi.kutski; an imitator, a mimic, one who frequently imitates the manners of others for the amusement of spectators.

ma î ma da ki, n., fr. madaki; a pencil, brush, or prepared stick used in painting pictnres.

ma í mạli i e lie, n.; playingcards. See imąkieke.

ma i mi dr ti. See iduks̄itiimisliti.

ma í pạ lia de, $n .$, fr. ipạkade; a fork, a table-fork.

ma i pa ja ki, n., fr. ipașaki; the belt worn around the waist, outside of the dress or shirt; the girdle.

ma í pa tsa ti, $n$.; synonymous with ipatsati.

waa l ptsa, n., ? fr. iptsa; an axe. ma y ptsa da ka, n., diminutive of maiptsa ; a latchet.

ma I si, n., fr. isi ; a covering; corn-husks.

ma i iké, n.,fr. isłke; one commanded, one obeying.

ma í :pa du mi di, $n$.; a snail. ma í iu, n., ? fr. isu; the wareagle, Aquila chrysaëtus. 


\section{man}

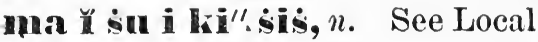
Names.

ma i su tí psa ki, n., fr. isuti and ipsakiki ; an apron.

lna i tá, $n$.; an arrow; syn. itá. ma i tá hi, $n$. See itahi.

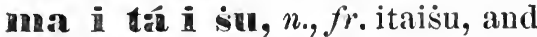
of similar meaning.

ma i ta múr a; n.,fr. tamua; a bell ; also maítamua.

ma i te í lu su ki, n., lit., material for washing the face; soap.

ma i te i ki pạ ki si, n., fr. ite, $\mathrm{i}$, and kipạkisi ; a towel. (I) 44).

ma i tir alu su ki, n., a con. tracted form of maiteidusuki com. monly used.

Ina i ti pe, n., fr. itipe; a fall. trap.

ma i tsi múi a, $n ., f r$ tsimua ; ornamental metallic pendants.

ma tski ti, n., fr. itskiti; a scissors.

ma in lii ki pki ti, fr. itulii and maikipkiti, and synonymous with the latter.

mak [wak], a prefix to verbs denoting opposition, reciprocity, etc. Sec maki and $\uparrow \mathbf{1 5 3}$.

ma ká, $n$.; my daughter (form of address).

ma ka dir sta [-ni-], $n$, fr. kadisita; a child, a young person.

ma ka drí sta i" dăk u dsi, $n$., fr. makadista and dakurlsi; a child's swing, or swinging cradle; an arrangement, for rocking chil. dren, made of ropes and blaukets and suspended from a beam. See mairlakudsi.

ma ka di sta ke, $n$.; a doll. See ke.

ma ka dì sta ma tse, $n$. (ma. tse, a man); a young bos.

\section{Imalí}

na ka dir sta mi a, $\mu$. (mia, $a$ voman); a young girl.

ma lía dir sta ti, $n$. See Local Names.

ma' kạ lipri ta ini [-wi], $n$.; hail.

Ina liại ptsi, $v$. $t$., 1st pers. of daliaptsi.

mạ Ka ta, n.; large fruit, particularly plums.

máx i, $x$. $i$., and adrerbial pre. fix, same as mạk.

mạk i a, $v$. $i$., fr. mạki; to contest, to oppose, to struggle with one another; to play a game in which opposite sides are taken.

mąk i a DÉ, adj.; checkered, cross-barred.

mạk i a pé lie, $v$. $t$.; to checker, to ornament with intersecting lines.

Inak i á ti di $\mathbf{e}^{\prime \prime}, v . i ., f r$ tidic; to run a contested race.

mak i á ti di e" ke; $v$. $t$., fr. tidieke; to cause to run in con. test, $i$. e., to race horses, to have a horse-race.

mak i dáa ksii, n., fr. kidaks̀i ; a very young child, one tied up in a bundle (as these Indians usual. ly carry children until they are about six months old); the bun. dle and child together.

ma ki dé ksa, n., fr. kideks̀a; an excessive romiting; a sickness characterized by prolonged or excessice romiting.

na ki dir ki, n., fr. kidiki; a hammer.

ma ki hil is, n.,fr. kidiši; a dance.

ma Lí ala nni $[+-w i], n ., f r$. kíllumi ; a numeral.

ma ki du tski si, n., fi. kidu. tskisi ; a lot of washed clothes. 


\section{II:}

mạli i é lie, $v$. $i$. and $t$.; to contest, or cause to contest; used in much the same sense as mạkia.

mạk i hí, $v . i . ;$ to stand mutually iil contact, as two sticks placed so as to support one another.

mạk i hi tă, negative of mạkihi; to be separated mutually.

mạk i i lé, $v$. i.,fr. maki and ille; to interchange speech, to hold a dialogue.

makk i i kín'pa, $v$. t.,fr. mạki and ikn'pa; to hate one another.

mạk i i si, n., fr. mạki and iši,so called because the covers or flaps close from opposite directions; a meat-case or parfliche case, which is an arrangement made of decorated raw-hide for holding dried meat and other articles.

mạk i ki dé si, $v$. t., fi. mạki and kidesii ; to love one another.

ma ki kú a, n., fr. kikua; a soldier; one of the Soldier Band of the tribe.

mạk i ma kă da ha, $v$.; to pass and repass one another com. ing from opposite directions.

mak i ma kă da ha ti dié, $v$. (tidie, to $r(n)$; to $\mathrm{rmu}$ or ride rapidly, passing and repassing one another, coming from opposite directions; as when tro persons, on foot or mounted, make a irar-signal.

mak i mạk i a [bakíwạkia], n.,fi. kimạkia; a battle, a figlit. ma ki pé, $n$., fr. kipa; hominy. ma ki pá hi, n., fir. kipahi; a song.-makipahi muk, gire (us) a song-a common mode of asking a person to sing.

mạk i pa tạ ki, $v$. t., fr. mạki and patạki; to shut together, to

\section{mák}

close together; to shut any thing when two sides are moved in the act, as in closing a book or a corered mirror.

na kó, pa, $n . ;$ my comrade; said by one female to another. See iko'pa.

mak sạ́ ki, $v$. t.; 1st person of dăkșạki.

mạk té ia, same as mạkises̀.

mạk sé sa dsi, arjj., fr. mạksese ; sceming to resemble one another.

makk ié ia du i, $v$. $i$.; becom. ing more and more alike.

mạts sé se [+wạk-], $v$. i., adj., fi. sese; mutually resembling one another, alike.

makl ié se le, adj.; closely but not exactly resembling one another.

mạk jé se ke, $r$. $t$.; to cause to resemble one another, to make alike.

mạk sí a, adj., fr. mạk and sia ; nearly the same as maksese.

malk $\vdots i ́$ a de, adj.; much alike.

mạk sí a ka, adj., fr. mạksia and lia; of the same size or length as one anotber; nearly synony mous with siaka and ścka.-mạksia. kats, thes are of equal size.

mạk sí a ka dsi, adj.; apparently alike in size or length.

mak ji a ka lie, v.t.; to increase or reduce in size so as to make tro things of equal length or size.

mak Isa ki, $v$. t., 1st person of dăktsạki.

mai kin, $n$; the cotton wood tree; perhays so called in allusion to its height.

má ku, $n$. ; night. The word is also used to denote the astro- 


\section{mák}

nomical day or escle of twentyfour hours, and sometimes to denote a year.

maí Lu, adj.; tall, loftr.

má ku a duı o" ki pa di, n. ; young cottonwood shrubs growing at the base of a tree. See aduokipadi.

má ka da, adv., fr. maku; during the night.

maí Ka dali, adv.; during the coming night.

nái Lu lá za, n., same as next uord, but less in use.

mí ku ka ri, n., diminutive of maku; a young cottonwood tree.

má lat ke, v. t.,fr. maku; to make tall ; made tall.

"néa hí mí di [-bidi], n., fr. maku, night, and midi; the moon.

mă ma, $v$.; a word used imperatively when trying to get an infant to drink or nurse.

má mpa da ki, n., fr. mạdaki; a picture, a painting; a book.

ma maglé - ke, n.,fr. mạkieke; a game in which opposite sides are taken.

ma múl a, n.; haw; haws.

ma nér a a, n.; haw-tree; a species of Cratcegus growing in Northern Dakota.

na o dé s̀a [-nesia], n., fr. desia, ? lit., a thing which is not; a thing of imaginary existence, a groundless storr, etc.

ma o dé sa a miś, $n$. See Local Names.

ma ba sí pi s̀a, $n$.; sunflower seeds,-used as food by these Indians.

ma páa tska ki di ti, $n$.; a wasp.

ma pé or má pe, $n$; day, daỹ.

\section{Iman:}

time; a period of twenty-four hours.-hidi-mapé, to-day.

má pe du, adv., fr. mape; during the day.

una pe ho pá, n., fr. mape and hopa; any day observed as sacred by white men, as Sunday and Christmas.

ma pé mi di [-bidi], n.,fir. mape and midi; the sun.

ma pi dăi lipa, $n ., f r$ pidalipa; ribbon.

ma pó ksaa, $n$.; any animal or animals offensive to the sight of these Indians or unfit for food, as insects, worms, snakes, etc.

ma pó ṡa, $n$.; a term applied to flies and insects less offensive to the sight than the mapoksa.

ma do sa Ki dir ti, $n$.; au ant. nna pú dsi ke, $n .$, fr. pudsike; a cord of buckskin or other material having porcupine quills or other ornamental trimming wrapped around it.

ma एоó ka, n., same as madoka.

ma pú lita, n., same as madulita.

Ina ذ่́a mi, ) $n$.; my aunt. See na śá wiś, ' išmi and dis̉ami.

ma si, $n$. ; a buffalo-robe; a blanket worn as a robe.

na sí, n.; a white man. The word was originally applied ouly to the French and Canadians, who are now sometimes designated as masika'ti, the true whites.

ma sí a de, $v$; to dream.-mamašíade, I dream. madasiíade, you dream.

ma si a lia, $v$.; to streep out dirt, to clean by sweeping with a broom.

ma si a í lia, n., $f i$. masialia ; a 
mas:

broom. The position of the particle ' $\mathrm{i}$ ' in this word is unique.

ma si dạ́ lia mi, n., fr. maṡi and daliami ; a shawl.

maa ii i lii, n., fr. masii and ilii; dry-goods of any description.

ma si i lii hía pi, $n$. (liapi, thin); light cotton goods ; muslin.

ma si i lia prí ni, n. (puzi, spotted) : c.slico prints.

ma si i lia tạ txi, n. (tạtsi, thick); cloth ; woolen goorls.

ma si i ptse, n., $f$. maşi and iptse; a wide, embroilered band in thecentre of a robe or blanket. ma $\dot{i}^{\prime \prime}$ i ta ă lipr tsi, n., lit., white man's bear; a hog.

ma si" i ta ă lipr tsi su i, 1". (śui, fat); vacon.

na si i ta inạk i e ke, n., lit., white man's gaming materials; cilruls.

ma si i ta mi te [-wite], $n$. , lit., white man's buffalo, or covo; domestic cattle.

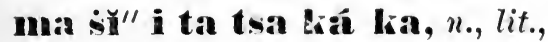
white man's bird; the domestic cock.

Ina sii ka, n.; chewing-gum.

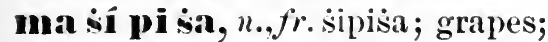
raisins.

ma ji pi sa a ku du" ti, $n$, lit., grape-eater; the cedar-bird, Ampelis cedrorum. (\$51).

na ji si pi sa, $n ., f r$. maśi and sipisia; the negro.

ma si ta, $n . ; m y$ back; from isita or tho hypothetical word sita.

ma si ta ká lisu, n., lit., white man's tuber; the potato.

ma sí ta ră liprí tsi, same as masiitadalipitsi.

IIa ذ̇์ a ka za, n., diminutive

\section{mat}

of masiuka; a puppy; willow catkins are also so called.

ma íu ka, n., fir. śkka; a dog.

ma ju ka ák su, $n ., f r$. mas̀uka and oaksue; the coral-berry or wolf-berry, Symphoricarpus.

na ju ka ák iu a ma $\dot{j i s ", ~}$

$n$. See Local Names.

na su ka íc ke, n., lit., Dog

Band; one of the orders or societies among the men of the tribe.

ma iu lia lia dî ìta, n., lit., Little Dogs; an order or society of the men.

ma su ka ma daí hi, n.; another of the bands or orders of the IIidatsa men.

ma tá, n., prob.ti. ta, to kill; altutumn.

ma tá du, adv., fi. mata; during the autumn.

ma tá duk, n., adr.,fr. mata; next autumn; luring next autumn.

ma tạ lii, $n$.; a turtle.

na tạ́ lii i sa, lit., resembling a turtle; a padlock.

ma tạ lipi, $n$.; a heary cord, a rope; a lariat.

ma tạ́ ki, $n$; a plate; a shallow dish.

ma tạ lí a du ki du ja, $n$.; a cup-board. See adukidusia.

Ina tá ki a zi, $n$. See Local Names.

ma tái lio a, adr., same as matekoa.

ma tái $\vdots$ i, $n$. ; $m y$ robe or blanket. See itasi.

na tạ tsi dá lio ke, n., frr. tạtsi and dalioke; an Indian pad. saddle.

ma tạ tsi ná lio ke, same as last word. 


\section{mat}

ma té, n., adi., fr. te or tie; long ago; a long time; the last rowel is often lengthened to indicate very distant past time.

ma té ko a, adv., fr.mate; at a distant time in the past.

má ti, n.; a boat.-Lutsi-mati (rind-boat), a sail-boat. midamati, a woolen boat.

má ti ìi sa, $n$.; a steam-boat.

ma tó ke, $n$.; a clam.

nuá tsa mi di [-bidi], $n$.; a bowl or basin.

nuá tsa mi di ka ri, n., diminutive of matsamidi ; a small bowl or basin.

ma tsé [watse, batse], $n$. ; a man.

ma tsé di di, $n ., f r$. matse and didi ; a war-party.

ma tse é tsi, n.; a chief; a person of prominence.

ma tslió ki, $n$.; eagle tail-feath. ers.

má tsi, n., contraction of maatsi. mă tsi, $n$.; my foot. See itsi.

ma tsi kó a, n.,fr. tsikoa; sugar; a sweetened drink.

ma tsi kó a a ku ti" due, $n$.; molasses.

ma tsi kó a ha" tski, $n$. (hatski, long); cands.

ma tsi kó a pu" zi, n. (puzi, striped) ; candy.

ma tsí ta hi au, $n ., f r$. tsita and hidu; the coccyx.

ma tsi tó, $n$.; a needle or awl.

má tsi to ic ti"l a, $n$. (ictia, large); an awl.

mái tsi to-u" ti po a du i, $n$. (uti and poadui); a pin.

má tsu, $n$.; small fruit, particu. larly cherries.

má tst a, $n$.; a cherry-tree.

ma tsú a, $n$.; fibrous tissue from me

the back of the buffalo, elk, deer, etc. It is dried aud split into fine threads for sewing, and is commonly called sinero by the whites.

ma tsu a pạ ki si, n., fr. matsua and pạkisii ; "sinew" twilled by rubbing, as it is fixed preparatory to being used in sew. ing.

ma tsu ạ tsa, n.; fragrant grass.

má tsu a mis̀, $n$. See Local Names.

ma tsíl ka, n.; my jounger brother. See itsuka.

má tsu o tak a, $n$.; the smaller dogwood, Cornus stolonifera.

má tsu o tạk i, $n .$, fr. matsu and taki; the berries of Cornus stolonifera.

má tsu tạ pa, $n .$, fr. matsu and tapa ; the service-berry, Amelanchier canadensis.

ma tsu tạ pá a, n.; the service-berry tree, shad-bush.

ma tí, $v$.; there are; there is ; ho has; they have, etc.; opposite of desia.

ma tíl a, $n$. ; green corn, roasting ears.

ma túl lii, $n$.; my dress or shirt. See itulii.

ma ú pa ki, n.; a mallet.

ma ú pạ ki hu" pa i șis̀. Seo Local Names.

má I tạ pi, n., ?fr. tapa; a ball of buck-skin or elk-skin stuffed with hair, and used by women in their games; a game played with such a ball.

má wa da ki, same as mamadaki.

má zi, n.; a legend, a tale.

me, $n . ;$ a louse. 


\section{mép}

mé pa ka, $n$., contraction of maepaka, but more common.

mé pi, n., contraction of maepi, muely used.

mi' [bi'], $n$. ; a rock.

mi [wi, wits], prob. auxiliary rerb, suffixed to denote 1st. person, future. ( $(107$ ).

mi, simple pers. pron., 1st pers., used independently or incorporated, nominative and objective, usually singular, but when incorporated may refer to more than one. ( $\Phi$ I 109, 110, 172, 205).

mi [wi, wrts], a suffix indicating number. See tuami and hi. dimi.

mi, a syllable or prefix of uncer. tain significance, beginning many nouns in the language; often pronounced bi, sometimes wi.

mí a [wia, bia], n.; a woman.

mi a dó lia ta [-no-], $n_{\text {. }}$; a harlot. This is the proper word; but madulita, fool, is often used.

mi a ka za, $n ., f i$. mia and kaza; a young woman.

mi á ti, n., fr. mia; a man who dresses in woman's clothes and performs the duties usually al. lotted to females in an Indian camp. Such are called by the French Canadians "berdaches"; and by most whites are incorrectly supposed to be hermaphrodites.

mi á ti he, $v$. $t$.; to become a miati; said of a man who assumes the dress and tasks of a woman.

mi á ti ke, $v . t$.; to cause to be a miati.

\section{mial}

míc ki, comp. pers. pron., 1st person ; I, myself. ( ( 117).

mi da [wi-, bi-], n.; a wildgoose.

mi dá [+bida], $n$. ; wood; a tree; a forest.

mi da a ku dú ti, n., lit., woodeaters; caterpillars which live on trees.

mi da á pa, n., fr. mida and apa; leares of any kind; tea.

mi da du é tsa, $n .$, fr. mida and luetsa; a wooden canoe, a "dug. out".

mi da ha, $n$. ; fire.

mi da há dsi, n.; willows; a name applied to all shrub willows.

mi da háa dsi hi si, $n$. ; red willow.

mí cla ha i du kạ pi, $n$. ; a friction-match.

mi da ha pó kja, $n$.; embers. mi da ha tíc ke, $v$. $i$.; to play as young children play; to play at any amusement in which opjosite sides are not taken.

mi da ho pá, $n$., $f$ rr. mida and hopa ; red cedar.

mi da ho pán-o kạ tsa du, $n$.; trailing cedar.

mi da hú pa, $n .$, fr. mida ond hupa; boots and shoes, such as are used by the whites. The Hidatsa probably originally sup. posed them to be made of rood. mi da hú pa i ki tsa" ti ke, $n . ;$ blacking.

mí da liạ, $n$. ; a pot or kettle. mi dlá lia si, $n$.; a basket.

mi dla i, $n$.; elm.

mi da i a ka ki, $n$.; a chair.

mi da i á ma lia ti, $n ., f r$. mida and amaliati; a torch; a candle. 


\section{mid}

mi ta i á ma lia ti-i o" ki, ? mi da i á ma lia ti-i o" pe, mui da i á ma lia ti-i $o^{\prime \prime}$ ptsa ti, $n . ;$ a candlestick. See oki, ope, and optsati.

mi da i á pi, $n$.; a spool.

mi da ic ke, $n ., f r$. mída and icke; the Goose Band, one of the orders among the women of the tribe.

mi da ic pa ti, $n$.; sunken tree or snag in a river.

mi da i ka ki, $n$. (kaki, roll); a wagon.

mi da i ó pë, $n ., f r$. mida and iope; a box of any kind, particularly a wooden box.

mi la I si, $n ., f r$. mida and isi ; bark.

mi da ka míc ka, $n$. (kamicka, tough); oak.

mí da ka za, n., diminutive of mida; a stick, a switch.

mi dá ki, $n$. ; a shield.

mi dạ bisi, n.; a palisade or stockade; a skillet or pan; so ealled perhaps because like a palisaded enclosure.

mi da lu é tsa, same as midaduetsa.

mi da ma 1 du tsa da, $n$. ; a wooden sled. See maidutsada.

mi da má ti, $n ., f r$. mida and mati ; a yawl or skiff.

mi dá pa, a contraction of mida. apa, often heard.

mí da pa, $n$.; bearer.

mi da tsa pi, $n$.; ashes; gunbowder ; dust.

mi da tsa pi a zis̀, $n$. See Lo. cal Names.

mi dạ́ tsa pi i si, $n$.; a powderhorn.

mi da tsí ka, $n .$, fr. mida and tsuka; boards; a floor.

\section{mid}

mi dé, n.; a door; a door-way. mi dé dii, $v$.t.; to come through a door-way, to euter a house; to pay a visit.

mi de ko a, $n$.; at or near the door; the seat around the fire nearest to the door.

mí di [bidi, mini], $n$.; water. The latter pronunciation, corresponding with the Dakota, is most commonly used in com. pound words.

mi di, $n$. ; a name given to both sun and moon ; it may be trans. lated luminary or great luminary. When there is danger of ambiguity they are distinguished as mape-midi (das luminary) and oktsi-midi or maku-midi (night luminary).

mi di [ widi] ], verbal root; turn, twist. See pamidi, dumidi, etc.

mi di a pó ka, n., lit., water head.dress; a rainbow.

mi di a té, adv., n., fr. midi and ate; when the sun (or moon) rises; sunrise.

mi di a té de, $a d v$.; near sunrise, just before sunrise.

mi di a té du, adv.; at sunrise, luring the time the sun is rising.

mi di a té duk, $a d v$.; when the sun shall next rise.

mi di a te ó dạk si pi, $a d v$.; after suurise. See dakșipi.

mi di dạ́ lii si, $n ., f r$. midi and dạhise ; a wave, a billow.

mi di dé ta, $n$., fr. midi, water, and deta; the bank of a river; the shore of a lake.

mi di dí di [-niri], $v ., f r$. midi and didi ; to swim.

mi di ho pá, $n$. See Local Names.

mi di í a pạ ti, $n$. ; a saw. 


\section{mid}

mi di í da liu pi, $n .$, fr. midi, i, and dalinpi ; a sponge.

mi di i hi' ke, $n ., f r$. midi, i, and hike; a drinking-vessel, a cup.

mi di i ki ki ski, n., fr. midi and ikikiski; a watch or clock.

mi di i mă lipi [-wă-], $n$, $a d v ., f r$. midi and imalipi ; sullset.

mi di í mă lipi de, adv.; near sunset.

mi di i mă lipi du, adv.; at sunset.

mi di í mă lipi duk, adv.; when the sun shall next set.

mi di í mă lipi se du, $a d v$.; when the sun did last set.

mi di i tá tsu, $n ., f r$. milli and itatsu ; the half-moon.

mi di lia, $a d v$., fr. midi, water; in or by the water.

mi di La líl lii, n., fr. midi, moon, and kakilii; the full-moon. mí di ka kir lii de, $n$.; the gibbous moon.

mi di ka ó ze [mini-], $n ., f r$. millika and oze, lit., They Plant by, or in, the Water; a band of the Teton Dakotas.

mi di ke, $v$. $t$., fr. mide and ke ; to liquefy, melt.

mi di ki da he, $f r$ midi, moon, and kidahe; the new moon, the crescent.

mi di ki dạk tsí e, $n$.; clear water, water allowed to settle.

mir di ó pe, contraction of mida. iope.

mi di ma pé du pa hi [bidiwapérupahi], $n ., f r$. midi, mape, and dopahe, lit., the sun divides the day in two; noon.

mi di ma pé du pa hi-dăk a-mí di, $n$.; afternoon.

\section{milh}

mii di ma pé du par hi-dlak sí pi, 1. ; synonymous with last work.

mi di ma pé du pa hi de, $n$. ; nearly noon.

mi di mí ta lia he, $n$; the Mindan medicine-ark.

mi dir pi, $r$; to enter the water, i. e., to bathe one's self.

mi ali sa, $x .$, adj.; turbid; said of witter.

mi dr sa a mis. See Local Names.

mi dil sa lie, v. t., fr. midrśa; to make turbia ; roiled.

mi dir si, $n$., contraction of midaiši.

mi di sí pi sa, n., fir. midi and sipisia; coffee, the infusion or decoction.

mi di tá di [minitari], $x_{\text {, }}$ comp. $v$., fr. midi and talli; to cross water, to go across a stream. The Hidatsa Indians; so called by the Mandans.

mi dri ti, $v$. $t$.; to cook by frying.

mi dri tsi, adj.; of a watery consistency.

mí do, pers. pron., plural; we; us.

mi do ki, pers. pron., compound, plural; we, ourselves.

mi dú e, $v$. $i$., fr. midi and ue; to bubble; to boil as water.

mi dú e he, v.t.; to boil water. mi dú e ke, v. t.; to cause to boil, to set to boil ; boiled.

mi dú lia [bi-], $u$.; a gun or bow.

mi dú lia lie, $n ., f r$. midlulia; a pop-gun.

mí c, $n$. ; woman, same as mia.

mi lia ka, $u$; a generic name for ducks. 


\section{mí'}

mi' i, n.; a stone or rock, same as mi'.

mi' i da' ta, n., lit., stone heart; a geode.

mi r ptsa, n., fr. mi' and iptsa; an axe, particularly a stone axe. See maiptsa.

mi h ptsa da' ka, n., diminutive of miiptsa; a tomahawk or hatchet, particularly a stone hatchet. See maiptsadaka.

mi ká, n.; a mare; as a suffix it indicates the female of all lower animals except buffalo.

mi ká', n. ; grass ; sedge; all grass-like plants.

mi ka' í du tsi, $n$., fr. mika' and dutsi ; a pitcbfork.

mi ka' Iri k'sa, n., lit., Grassfixers; an order or degree among women.

mi ka' tó hi saa, adj.,fr. mika' and tohisia ; green.

mi ka' tsạ ki, n.; a name sometimes applied to fragrant grass.

mi ka' íl dsi, n., lit., dry grass ; hay.

mi ka' í ta ku du ti, $n ., f r$. mika'uti and akuduti; a caterpillar that eats onions.

mi ka' í ti, n., fr. mika' and uti; onions; wild garlic.

mí' Ka za, n., diminutive of $\mathrm{mi}^{\prime}$; gravel, pebbles.

mi ktá [wim], $n$. ; the bottom, the lower part or surface of anything.

mi ktá ka [wi-], adv.,fr. mikta; at the lower part; below.

mi ktá ko a, $a d v ., f r$. mikta; near or at the bottom; under.

mi ktă ta, $a d v ., f r$. mikta; downward, in the direction of the bottom.

\section{mit}

mi' ma ná pa li i, n., fr.mi and maupạki; a stone-headed mallet, such as is ordinarily made by these Indians.

mi spá [bispa], n.; the ashtree.

mí ta pa [witapa, witapants], v. $i . ;$ to lie, to deceive.

mi ta pá dsi, $v . i ., f r$. mitapa; to equivocate.

mi ta pạ ksa, v. i., fr. mitapal; to lie frequently or habitu. ally.

mi té, n.; a buffalo.cow; the word is also used generically.

mi té a ka mi, n., diminutive of mite; a buffalo-calf.

mí té a tă di ke [biteatănike], $n . ;$ the box-elder, Negundo aceroides.

mi té a tạ ki, n.,fr. mite and atạki; an albino buffalo, whito buffalo.

mi té a tạ ki ic ke, $n$.; the White Buffalo Band, a secret degree or orler among women of the tribe.

mi te Ktsa tsa, $n$; the black currant.

mi té latsa tsa a, $n$.; the currant-busb.

mi té o dă hipi, $n$.; a buffalohide.

mi' Ii, $v$. $i$.; to creep, as a hunter approaching game.

nni tsạ ki, $v_{\text {. }}$ I alone; I unaided.

mí tsi, $n$.; a wedge for splitting. wood.

mí' tsi, verbal root; mince; comminute finely.

mí tsi a da mi. See Local Names.

mi tsí i ta mi dạ ksi. See Local Names. 


\section{mit}

mi tslia pá, $n$.; the fruit of the rose; it is eaten by Indians.

mi tska pa á, $n$. ; a rosebush.

mi tska pa ó dák a pạ ki, $n$; rose-blossom. See odakapạki.

mó tsa, n.; a coyoté (Canis latrans).

mó tsa i ta ma ka ta, n., lit., coyote's plum; the fruit of Astra. galus caryocarpus.

mú, verbal root. See mua.

mú a, $v$. or verbal root; to sound, to make a noise. See liamui, tamna, tsimua, ete.

múua [bua], $n$.; generic name for tish.

mu a dá ki, $v$. $i$.; to bark as a wolf or dog; to imitate the howl of a wolf, as Indian hunters commonly do when calling to each other in the woods.

mu a í du toku pi, $n$. ; a fishhook.

mu ă pă dé lii, n., fr. mua, ăpă, and delii ; sturgeon.

mu ă pă há tski, $f r$ mua, ăpă, and hatski ; gar-pike (?).

mu a tsú ka, $n$. (tsuka, flat); sun-fish.

mú dsi [wudsi], verbal root; roll up, fold by rolling.

mú pi [wupi], v. t.; to smell. mú ti, $v$. $t$., 1 st pers. of duti; I eat.

\section{n.}

n. Words heard to begin with the sound of $n$ may be found under $\mathrm{d} ; \mathrm{n}$ and $\mathrm{d}$ being interchangeable letters. ( $(\uparrow, 20$ and 21.) oda

o.

o, $a d v$. ; much; used in compounds; syuonymous with ahu, which may be derived from $o$.

o, a prefix to rerbs forming nouns which are names of places aucl actions; often s,ruonymous with - allu. ( ( 49,50$)$.

o, a pretix of undetermined meaning to rerbal roots. In the 1 st and 2d persons, it commonly takes $m$ and $d$ as pronouns, preceded by a. ( 1977 ).

o da $[-\mathbf{n} a], v . t$. ; to pass another person on the road either by overtaking or meeting him.

o dă lipi [-nălipi, -rălipi], $n ., f i$. dalipi ; the hide of an an. imal, the entire hide.

б dăk a pạ ki, n., fir. dalkapạki; a flower, a blossom; sometimes accented on peuultimate.

ó dăk a prr lii, $n ., f r$. dakapilii ; an ornamental flap on a garment; also odakapǔlii.

6 da lii, $v . i$; to chirp, to make a stridulous sound.

б dăk sạ ki, $n$., fr. daksạki ; a contused wound ; the act of giv. ing a contused wound.

ó dăk si pi, $n ., f r$. daks̉ipi; a subsequent time, a time after some other time mentioned.

o dá mu, $n ., f r$. damu; a deep spot in a stream; the channel of a river.

ó la pi [-ra-], v.t.; to find, to make an original discovery; not to recover something lost.

ó da sa' ti [oma-], $n$. ; a name, a designation; not a proper name. 


\section{óda}

б da sa' ti, $v . t$.; to name, to speak of or call by name. In the conjugation of this word, $o$ is not preceded by a, as in other verbs beginning with ' $o$ '. -omadaśa'ti, I name. odadaśa'ti [olanasid'ti], you name.

o dí di, $n ., f r$. didi ; gait, walk.odidi is̉ia, said of a lame person.

o dú se, $n ., f r$. duse; a place of deposit.

O du ska skạ́ pka, n.; spruce gum, such as the Indians themselves gather. That obtained from the traders is called masíka.

o dúr tsi, $n ., f r$. dutsi; a mine; a place where anything may be obtained with certainty.

o hi, $v$. t. ; to be fond of ; said of the affection of pets for their owners.

ó ha ta dui, $v$. $i$.; becoming pale.

o lia ti, adj., fr. liati; white, oright, clear, or pale; often used synonymously with ilio. tạki.

ó lia ti ke, v.t.; to make pale, to bleach or whiten.

б lia ti lasa, adj.; continually or habitually pale.

ó ka, $n ., a d v$.; yonder, over there.

б ka du, $a d v$.; in a distant place (pointerl to), youder; beyond.

б ka lao a, adv.; at a distant place, at yon place; at the other side.

o ka ta, $v . t$.; to put on an article of clothing, to dress.

o ki, v.t.; to surround the base, to surround one end of an ob. ject; to maintain in position or support by thus surrounding,-

\section{opă}

as a candle is held in a candle. stick, as the teeth are held in the gums.

o ki, $n$. ; a plume, a feather, some. thing plumose.

o Lí íc pu, n., fr. oki and icpu; a tassel.

o Li pa di, $v$. $t$., fr. oki and apa. di ; to grow up around; said of young saplings or twigs growing around a parent tree.

- Li pa pi, $v . t$.; to find, to recover something lost. See I 197.

6 ktsi, n., ? fr. katsi ; darkness; hence, one of the names for night.-hidi oktsi, this night.

- Ktsi a de, $n ., a d v$.; almost night; almost dark; after sunset.

o ktsí a du [-res], $a d v$.; during the night.

- Latsí a duk [-puk], $n ., a d v$; next vight; during the approaching night.

o ktsí se du, $n ., a d v$.; last night ; during last uight ( $\Upsilon$ I 256,257). oktsisedu itaokakoa, before last night.

o lotsí se ru, same as last word. - Lá wu, same as odamu.

б' pa, $n$.; evening, near sunset.

б' pa de, $n ., a d v$.; near evening, late in the afternoon.

- pa du, $a d v$.; during the evening.

б'pa duk, $a d v$.; during the coming evening.

б pă pe, v. t.; to bedaub slightly, to bespatter, to stick on in small quantities.

б pă sa, ? $n$.; a tucking.

O pă sáa ku, $n$., fr. opaśa and ku; to give a tucking, $i$. e., to tuck in the edges of bedding. 


\section{б́pa}

ó pa se, $v$. $t$.; to tuck berlding.

o pe, $v . t$.; to contain to hold, as a box or vessel.

б pě, $n$. ; tobaceo. This name is often applied to articles mixed with, or used in place of, tobacco, as bark of Cornus or leaves of uva ursi.

ó pě ha sa or općhaja, $n$.; the bark of Cornus stolonifera, or Cornus sericea, dried and prepared for smoking, "kinnekenick".

ó pe hi, $v$. $t$., comp. of ope and hi; to smoke tobaceo or any substitute for tobacco.

ó pe i si, $n$., frr. ope and iši ; a tobaceo-bag.

o pe pa mí tsi, $n$., fr. ope and pamitsi ; a board on which tobaceo is ent. This word is not formed according to ordinary etymological rules: it was prob. ably originally opeipamitsi.

o psia sa, $v . t$.; to stop, to jar, to arrest motion; said of an object against which a person stumbles in walking.

ó ptsa ti, $v$. $t$., to encircle or surround closely; to hold by surrounding elosely; ofteu used synonymonsly with oki.

ó ti, $v$. i., adj.; cooked ; ripened ; scialded.

ó ti he, $v . t$.; to scald or cook.

o ti ke, $v . t$.; to cause to cook or ripen; to put fruit away to ripen.

ó tslia mi [-wi], v. i., adj.; numb; paralyzed; said of the feeling in the limbs produced by pressure, and commonly called "sleepiness".-matsi otsliawits, my foot is asleep.

ó tslia mi ke, $v$. $t$.; to make numb, or "sleepy".

\section{páli}

o ze, $n_{.}, f i$, the verb; a drink, it etup of water or other fluid.

ó ze, $v$.t.; to pour into, to fill or partly till a vessel; also to plant or sow seed.

\section{p.}

pa, $v . t$; to reduce to powder by grinding or pounding.

pa, i prefix to verbs, commonly signifying that the action is performed by the hinds or is capable of being performed by the hands. ( $(151)$.

pa dó pi, adj., ? fr. padui ; short in stature, low-sized.

pa dó pi di, adj.; very short.

pa du á du i, $v$., fr. padui; shorteuing; decreasing in length. pă du i, adj.; short.

pá dn i di di, $n .$, fr. padui and didi; ceremonial processious performed by bands or secret orders of the tribe, in which the performers follow one another in a eirele, taking very short steps and singing as they move. These processions are commonly called "medicine dances" by the whites; but the Hidatsa apply a different term to a dance.

pă du i ke, $v$. $t$.; to shorten; shortened.

pă du i lísa, $v$., adj.; constantly and excessively short.

pá hi, $v$; to sing.

pá lia da i, $v$. $i$; becoming chafed or blistered.

pa lió hi, v. t., ? fr. liolii ; said of ice when it begius to break in the spring.

pá liu, $v . t$; to spill; imperative form. 


\section{páli}

pá liu e, $v$. $t$., fr. liu or liue; to spill out, to pour; to empty by pouring.

pạ ka dé, v. t.; to stick into or thrust th rough, to impale.

pa kạ pi, $v . i ., f r$. kạpi; to be torn, as in walking through rosebushes.

pạ kĭ di, $v$. $t$. ; to push, to shore away with the hand.

pạ Iai si, v. $t$.; to rub gently in one direction with the hand, as in smoothing the bair or stroking a cat.

pa ki ti, v. t., fr. kiti; to press to smoothness, to make smooth by pressure with the hands.

pa mí di, $v . t ., f r$. midi ; to twist with i he hand.

pa mǐ tsi [-witsi], v. $t .$, fr. mitsi ; to cut fine by pressing ou with a knife held in the hand, as in cutting up tobacco or other material on a board preparatory to smoking.

pa mú dsi [-wudsi], v. t.; to roll up with the hands, to roll as a long strip of cloth or carpet or bandage is rolled; to fold or pack by rolling.

pa sán ki, $v$. $t$.; to engirdle or cover, as with a belt.

Da sá ki, $v$. t. ; to love or like; possibly a figurative application of pasaki, to engirdle.

pa skú, $v$. t., $f r$. sku ; to extract by pushing with the hand, to shove a cork into a bottle, to push a bullet out of a wound.

p̆̌̀' tă, imperative of pŭ'te.

pa tán ki, v. t.; to place in contact. See ipatạki, kipatạki, and mạkipatạki.

pæ' te, v.t.; to turn over; to tumble over. pat

par ti, $v . i$. ; to fall down off of, to drop from a height.

par ti he, v. t.; to throw or knock down; to throw down from.

pa ti ke, v. $t$.; to cause to fall, to throw down, to remove a support and allow to fall.

pa tó' ti, $v . t ., f r$. to'ti ; to wave or agitate back and forth; to wave with the hand; to make a sigual by waving.

pá tsạ lii, v. t., fr. tsạke ; to cut; to cut with a knife or instrument held in the hand.-patsak, imperative.

pa tsá' ti, v. t., fr. tsati ; to puncture.

par tsa ti, $n$. ; the west, the land to the west of the Hidatsa.

pă tsa ti lia, adv.; westward.

pă tsa ti lioa, $a d v$.; a.t or in the west.

pạ tska, adj.; flattened, having one or more plane surfaces.

pa tská pi, $v$. $t$., fr. tskạpi ; to prick with a piu; to stick with an instrument held in the hand.

pạ tskạs, $n$. proper. See Local Names.

pạ tskî di a, $n ., f r$. pạtska ; cactus, particularly the different species of Opuntia or prickly pear.

pạ tskí di a ó lía, $n ., f r$. pạtskidiaoki and a the round cactus of the Upper Missouri, which bears a pleasant edible fruit.

pa tskĭ di a ó ki, $n$., fr r. pạtski. dia and oki (alluding to the way in which the fruit grows on the plant); the fruit of the round cactus or Mammillaria: The name has recently been applied to figs. 


\section{pat}

pạ tslír pi, v.t., fr. tskupi; to fold up as a blanket or robe is folded.

pa wi di, same as pamidi.

pe, $v . t$; to swallow; to take a meal in which both liquid and solid food are served.

pe, $v . t$.; to grind, as coffee in a mill.

pe da lau dú ti, $n ., f r$. pedi, aku, and duti; a vulgar name sometimes applied to dogs; offensive epithet applied to persons whom they wish to liken to dogrs.

pe da liu pă' te, $n ., f r$ pedi, aku, and păte ; a species of beetle.

pé de tska, $n$; the large crow or raven.

pé de tska i ta lii" pi sa, $n$.; Phlox aristata.

pe de tolíi sta pé di, $n ., f i$. pe. detska and istapedi; a sort of soft hail or snow falling in glob. ular flakes, "mountaiu snow".

pé di, $n$.; any offensive matter or excretion, dregs, ordure.

plié ta, $n$.; nasal mueus.

plié ta ì si, $n$.; a pocket-bandkerchief.

pliu, verbal root, or : $f \circ$ liu; squeeze out and let fall.

plin ti, $v$. or verbal root ? $f$. pliu or liu ; squeeze forward, squeeze out. See kipliuti.

pi, v. $t$.; to tattoo.

pi, verbal root; penérate. As a verb, often used synonymously with ipi.-mapi, dapi.

pí a, $v . i$. crepitate.

pi ă ti, $v$. $i$., fr. pia; denoting desire or readiness.

pi dă lipa, v., adj.; light and thin, as silken goods.

\section{púa}

pIr di e, $v ., a d j$. ; ruffled or frilled, ornamented with a ruffled border.

pi ć, v., adj.; smoky ; said of atmosphere rendered disagreeable by smoke.

pi é ksa, adj.; constantly and disagreeably smoky.

pi ta kic tí a, adj. See pitikictia.

pí ti ka, num. adj.; ten.

pi ti kic tí a, num. $a d j$., fr. pitika and ictia; one hundred.

pi ti kic tí a-á lá lao di, num. adj.; one tbousand.

plíi ti, $v$. t., fr. kiti or plakiti; to smooth out; to iron clothes.mapkiti, I smooth. dapkiti [ua], you smooth. The word pkiii alone is rarely heard ; for in the third person the intensive form, kipkiti, is used.

pó a du a alsi, $a d j . . f r$ poadui; of a hemispherical or somewhat spherical appearance.

pó al du i, adj.; globular, hemispherical, or nodular.

pó a lu i lie, $v$. $t$.; to make globuiar.

pisu, verbal root; dislocate; knock out of liue.

pśn lí, $v . i$; to belch.-mapisuki, I belchl. dapsuki, you belch.

pśu kíc ti, v. i., fr. psuki ; denoting desire or readiness.

pśá ti, $v$. t., fr.psiu; to dislocate.kipsuti is the more common form.

ptsín ti, v. $t$; to shove or thrust forward, to protrude. See kiptsuti, which is the form most commouly used.

pú a, v. $i .$, adj.; tu swell; to be swolleu, as a bruise; also to rot or become putrid. 


\section{púa}

pú a de, $v . i ., a d j . ;$ to be tainted or sour, but not decidedly rotteu.

pu á de i, $v$. i. ; becoming swollen, swelling gradually and constantly.

D面 a lse, $v . t$. ; to cause to swell, to inflict an injury which produces swelling; swollen.

pu á lisia, $v$. $i$. ; constantly swollen.

pá disi, v.t.; to mark with fine indentations closely set; to sew with fine stit shes; to wrap tine thread closely around; to wind colored horsehairs or porcupine quills closely around a buckskin string for ornament. The object of this verb is the name of the material used in wrapping or marking.

pú alsi ka e, $v$. $t$; t to cause to be finely sewed, indented, or en. wrapped. The object of this verb is the name of the article on which the marking or wrapping is done.

pu é, $n$. ; visible vapor from warm water; mist, fog.

pu $e$, v. $i_{.}$; to steam (said of water); misty.

pú liạ ki, $n$. ; sand.

pu" liạ ki a té, $n ., f r$. puliạki and ate; a sand-bar appearing above the surface of the water; a sandy island.

pú lii, $n$. ; foam or lather.

pú lii, adj.; freckled, blotched.

pú lii, $v$. $i$. ; to foam.

pú lii ke, $v . t$; to cause to foam, to agitate until a foam is produced.

prí pu, $n$.; a tall species of grass, the Dakota cedi.

púi zi, adj.; spotted, figured, or striped.

\section{sah}

pú zi ke, $v . t$. 10 mark or ornament with spots or figures; spot. ted.

pú zi ke, n.; the domestic cat, an animal not long known to this tribe. The name is said to come from puzi; but it was probably, to some exteut, suggested by the English term pussy-cat.-puzike sounds just as the Hidatsi would be most likely to corrupt or mispronounce pussy-cat.

pú zi ke da ka, $n$.; a kitten.

$\mathbf{r}$

r. Words heard to begin with the sound of $r$ may be found undep $\mathrm{d}$, these letters being interchangeable. See If I 19, 20, 22 .

s. Words heard to begin with the sound of $s$ may be found in this dictionary with ts for their first letters. See $\mathbb{1} 17$.

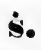

sa, n.; same as sada.

san á ka, n.; a frog.

săi da, $n$.; pudendum muliebre.

;a hë, n.; the Uree or Knistineaux Indians. Assineboine "sha-i-ye". Other tribes of this region call the Crces by names which sound much like sahe or shaige. There are various explanations of the derivations, but they are all doubtful. 


\section{sák}

sá ka, $n$., same as saaka; a frog. In the first syllable, the rowel is prolonged or pronounced as if doubled.

sa laa du súu ki, $n ., f r$. saki and adusuki; the kuuckles.

sa lián pi, adj.; tepid, lukewarm.

sa kái pi he, $v$. $t$.; to make tepid. sá lai, n.; the human hand; sometimes applied to the forepaws of brutes.-isaki, alone and in derivatives begimning with it, is commonly preceded by the pronouns. See išalii.

sa ki a du tsá mi he, $n$. ; fügers.

sa lai du má ta du, $n ., f r$. saki and dumatadu; the middle finger.

sa ki i ó ptsa ti, $n .$, fr. șaki and ioptsati; a finger-ring.

sá ki i ta ki da ka" he, $n ., f r$. saki and itakidakahe; a spau; a span measure.

sá li ka zi, $n$., diminutive of $\dot{s} \mathrm{~s}$. $\mathrm{ki}$; the little finger.

sa lói laa zi fr ti du, $n$.; the third finger. See utidu.

sa lii ó ptsar ti, a contraction of siakiioptsati.

sá ki ta, $n$.; the thumb.

sa líu pa du i, $v$. i.; becoming crooked, warping.

sa liú pi, adj.; crooked.

sa kú pi he, $v$.t.; to distort; to bend.

sa kú pi ke, $v . t$; to make crooked.

sá mi, hypothetical word; aunt. Sece iśami.

sá pu a, num. adj.; seren.

sá pu a he, $v$. $t$.; to make into seven forms or parts.

sá pu a he ke, $v$. $t$.; to cause to

\section{ṡét}

make into seven ; nearly sinonymous with sapuake.

sá pu a lie, $v$. $t$.; to separate into seven parts, to divide into serenths; divided into serenths.

sa pú a pi ti ka, num. adj.; serenty.

sá sa, $v ., a d j . ;$ to fork or divide; forked, branched.

sa sír ka du i, $v$. $i$.; becoming dull or blunt.

sa síl ki, adj.; dull, as an edgetool.

sa sún ki he, $v$.t.; to tickle.-nisasukimáwits, I will tickle you.

sa sú ki ke, $v$. t.; to cause to be dull.

se, demonst. pron.; that.one, that thing.-Dets, that is he, that is the very one.

sé du, adv., fr. se and du ; there; then; at that very time or place. As a suftix, this word is used to denote time, as the English last or ago. ( $(255)$.

sé i ske, $a d v ., f r$. se and iske; just as directed, just as ordered. sé ka, $a d j ., f r$. se and ka; of the same size as something previ. ously described.

sé lio a, adv., fr. se and koa; there, at that very place.

sé ru, adv., same as sedu.

sé sa, adj., adv., fr. se and ișa or ise; same as șeśe.

ذ̇́ se, $a d j$., $a d x$.; resembling something previously described, "just like that".

sé sets, a form of the last word used when it is desired to agree with some particular version of a story; "it is just as you say". sé tă, $a d v$. ; "not the same as that", "not just that".-_ietăts. sé tsa ki, verb or phrase used as 


\section{sía}

a pronoun; that alone; he or she unaided or unaccompanied. si a, synonymous with se. Possibly the latter is a contraction. sí a ka. See seka, sisikạts. sí di, adj.; tawny, dull yellow. sí di lie, v. t.; to make tawny, to color a dull yellow.

si dî si, $v$. $i ., f r$. disis ; to hasten, to be in a hurry.-disidisis, hurry thou.

si dIr si ke, v.t.; to cause to hurry, to make hasten.

si kár ka, $n$.; a young man.

si ki a, adj.; curly, as the hair of a buffitlo; said also of tangled underwood.

sir ki he, $v$. t.; to curl.

si pa, $n$.; the bowels.

si pe, $a d v$.; tangled, hard to penetrate ; said of bad-lands, dense woods, etc.

sir pi, adj.; black, pure black.

sir pi he, $v$. $t$. ; to blacken ; to aply powdered charcoal.

si pi sa, $a d j ., f r$. sipi and is̀a; blackish; of a very dark blue, brown, or other color scarcely distinguishable from black; often applied to pure black.

sí pi sa de, $a d j . ;$ almost black, distinguishable from black, but approaching it.

si pi sa dsá du i, $v$. $i$; becoming dark, as the face from exposure to weather.

si pi sáa Isi, adj.; resembling black, seeming to be blackish.

si pi sá dsi he, $v . t$.; to darken, to deepen or darken the color.

si pi sá dsi ke, $v$. $t$.; to dye of a darkish color.

si pi să du i, $v . i$.; darkening, becoming blackish (as iron allowed to cool); said when re-

\section{ta}

porting the progress of an operation for dyeing of a blackish color.

sí pi sa lae, $v$. $t$; ; to make very dark; to dye any thing of a black or blackish color.

si ta, hypothetical. See isita. ske, $v$.; command; direct.

sku, verbal root; force through, extract.

só ki, adj.; broad; often used for dull. See silsuki.

síu a, adj, adv.; slow ; slowly.

sín a ha, $a d v$.; slowly.

sín a ke, $v . t$.; to cause to move slowly, to retard motion.

síl e, $v$. $t$. ; to spit.

śú i, n.; unmelted fat, adipose tissue.

Sí ka, perhaps hypothetical ; a dog, a beast of burden; same as Dakota, sunka; funnd in the words itsuaśuka, itaśuka, maṡuka, etc.

sú ki, adj.; same as s̀oki.

\section{t.}

ta, adv.; only, but ; cowmonls pronounced as if suffixed.

tă or ta', an adverb and adrerbial suffix denoting negation; not. As it commonly termiuates a sentence, it is often beard pronounced tăts. Ex.-itskits, it is large enough. itskităts, it is not large enough. ( (ा 260).

ta, a suffix to nouns and pronouns denoting possession, particularly acquired or transferable possession. (П 85).

ta, prep.; toward, in the direction of, etc.; suffixed to nouns, it forms adverbs. ( $(\pi$ 261). 
ta

ta, $v$. $i$. and $t$.; to kill; to be killed.

tá da to di [-Ia-], to discharge a gुun.

ta d6, v. i.; almost killed; nearly dead.

tá $\mathbf{l i}[-\mathbf{r}], v . t . ;$ to cross over, to go from one side to the other; to row or swim across a stream.

tá du, hypothetical. See itadu.

ta hé, $v$. t., fr. ta; to kill; he kills.-tamats, I kill. tadats, you kill. tahets, he kills.

ta hú,, n., $v$.; thunder; to thuuder. Like most otber tribes of the plains the Hidatsil attribute thunder to the movements of a great bird.

ta hú i da lia, n., fr. tahu' and iclaka; low rumblings of thunder following a loud peal.

ta hí i kì siș, $n$. See Local Names.

tá ka, interrog. pron.; what; which.

ta lia tá $[-\mathbf{r a}]$, what do yon say?

tá la a ta, inter. adv., fr. talia; in what direction, whither.-tápata and tóta are synonyus more commonly employed.

tạ ki, adj.; white. See atạki and iliótạki.

ta mú a [tabua], $v$., fr. mua ; to make a loud ringing sound, to be ringing, to ring.

ta Iańi lii, adj.; very fiue, miunte.

ta mú lii di, adj.; exceedingly fine, very miunte.

tá pa, interrog. pron.; what? what is it?

tạ P๕́, adj.; soft, easily broken or yiclcling.

tạ p:í i, adj., same as tạpa.

\section{tip}

tá pa ta, $a d v$; in what direction, whither. - tapata dade, where are you going?

ta pé, interrog. pron.; who.

ta pé I Ia, interrog. poss. pron.; whose.

ta pé ta, same as tapeita.

tạ pi, verbal root; press, squeeze. See dutapi, etc.

tă ta, adv.; referring to past time not very distant; a short time ago, some time ago.

tă ta ko a, adv.; at or during a past period not rery distant.

tạ tsai dsi, alj., fir. tạtsi; thickish, appearing to be thick.

tạ txá du i, $v$.; thickening.

tạ tsi, adj.; thick, as cloth, etc.; also used to express total ob. scurity of the sky. See apalii. tạtsi.

tạ tsi ke, $v$. t.; to thicken; thickened.

ta w'́ lii, same as tamulii.

te, $v ., a d j$. ; dead.-tets, he is dead.

te dín ti [-ruti], n.; a prairio terrace; a low open plain.

té he, $v$; to die.-temats, I am diying. temamits, I will die.

ti, a suffix to verbs denoting read. iness or desire to pertiorm an action; to be about to -.

ti a, adv., same as tie.

til di a, $v . i$; to run.

tì di é lie, v.t.; to cause to run; to race a horse.

ti e, n., $a d x$.; a long time; long continuing.

tí e dak [-ruk], $a d v$.; referring to distant futurity.

tí e hi duk, $a d v$.; when a distant future time shall arrive.

ti pi a, $n$.; murl.

ti pi a da zi. See Local Names. ti pi áa tsa ki, v., adj., fr. tipia 


\section{tip}

' and tsaki; soiled with mud, bespattered with mud.

ti pi á tsa ki lae, $v$. $t$; ; to cause to be soiled with mull.

tí sa or tí se, $a d j ., a d v$. ; far, dis. tant; to a distance.

ti tsá du i, $v . i ., f r$. titsi ; thickening, increasing in diameter.

tri tsi, adj.; thick, as a fat or swollen limb or the trunk of a large tree; refers to diameters of cylindrical bodies.

tr tsi ke, v. t.; to thickell, to in crease in diameter; thickened.

til tsi lisa, adj.; thick excessively and habitually, as a permanintly swolleu limb.

to, interrog. adv. and pron.; what place? what person? what kind or color ?

tó du [-ru], adv., fr. to and du ; in what place? wherein? whereat?

to ha dsá du i, $v$. $i ., f r$. tohadsi ; assuming a bluish hue.

tó hà dsi, adj.; having a bluish or impure blue color.

tó ha dsi ke, $v$. $t$.; to dye an iu. pure blue color.

tó ha du i, v. $i$. ; assuming a blue color.

tó hi, adj.; blue; denotes pure or positive blues, sky-blue, ultra. marine.

tó hi ke, $v$. $t$.; to dye anything a pure blue.

tó hi sa, adj., fr. tohi and iša ; of a color allied to blue; green. See mika'tohisa.

tó hi sa ke, $v . t$.; to dye anything green or other color allied to blue.

tok, $a d v . ;$ it is used after sentences and verbs to denote prob-

\section{tsa}

ability or uncertainty; bence, it is often used interrogatively and is frequently followed by madiets, I suppose.

tó ka, $a d v$., fr. to and ka; whereto? where? whither?

tó ka ta or tó kta, synonymous with toka.-tókatadade [toktarade, toktalale], where are you going?

1 1 pa, num. adj.; four.

tó pa he, $v$. $i$. and $t$; ; to part in fuitr.

to pa hé lke, v. t.; to cause to part in four.

tó pa lie, $v$. $t$. ; to divide into four parts; divided into four parts.

to pái pi ti ka, $n .$, adj., fiv. topa and pitika; forty.

tó sa, interrog. adv., fr. to ; how? in what manner?

to sé, interrog. adv.; why? wherefore?

tó ta, interrog. adv., fr. to ; in what direction? toward what place? - tótadade [totarade, totalale], in what direction are you going?

to' ti, verlual root; implying sudden, repeated reversion of motion. See dato'ti, duto'ti, pato'ti, ete.

tsa, adj. ; raw, uncooked.

tsa, verbal root; separate, divide.

tsá dla, $n$. ; grease, oil.

tsá da, $v$. or verbal root; slide, move smoothly.

tsá da ke, $v . t$.; to make slide, to cause to assist to slide.

tsa dá tsa ki, $a d j ., f r$. tsada, grease, and tsaki; soiled with grease.

tsa hi du mi di, $v$. $i ., f r$. dumidi; to suffer from vertigo. 


\section{tsa}

tsa Iáá dsi, adj., fr. tsạki; mod. eratels good: rather pretty.

tsa hiá dsi kie, $v$ t.; to matie moclerately good.

tsa láa da $i, v . i$; improving, becoming good.

tsa kạk', interj.; an expression of contempt or disapprobation.

tsa láa laa, $n$.; a bird.

tsa láí ka da ka, $n$.; an egg ; egrgs.

Isa ká ka hi, $n ., f r$. tsakaka and hi ; feathers, any portion of a birel's plumage.

tsa láá ka i lĭ ši, n.; a bird's nest.

tsạ le or tsali i, modified verbal root; to cause to be divided.

tsá ki, v. $i .$, adj.; to be stained with -; to be rendered offensive; suftixed to nouns it forms adjectives; as amatsaki, tsadatsaki, et al.

Isạ ki or tsạkits or sạkits, adj.; good; pretty; often accentel on last syllable.

tsá lii, $v$; alone, by itstlf ; used only witb pronouns. See ítsạki, mítsạki, and setsạki.

tsa kic ti, adj.,fr. tsạki ; very good; very beautiful._tsakíctidi denotes a still higher degree of excellence than tsakicti.

tsạ hi há, adv.; quiet, quietls.

tsạ ki há mak, v. comp., imperative, fr. tsạkiba and amak; sit quietly, stay quiet.

tsạ lai he, v., adv.,fr. tsạki ; well, in a satisfactory manner; to act well.

tsạ ki ke, v. t., fi. tsaki ; to improve, to make good, to cure a disease; improved, cured, restored.-kitsakkike is more frequently employed.

\section{tsa}

tsa kis, $n$.; something inferior or worthless, a nuisance.

tsa málk, a form of tsame, used in the sense of a noun.- - tsamak isiats, its being hot is bad, $i$. e., the heat is oppressive.

tsa mé [-we], adj.; hot, very warm.-tsawéts, it is hot.

tsa mé a te [-we-], $v, i ., f r$. tsame and ate; to perspire.

tsa mé he, $v$. $t$.; to beat.

tsa mé lie, $v$. t., to make hot, to chinger from hot to cold; heated.

tsa nać lisis, adj.; constantly warm; very warm.

tsa mú tsa alji [-wu-], adj., $f i$. tsamutsi ; straightish, hearly straight or appearing to be straight.

tsa mú tsa du i, $v$. $i$. ; straight. 'ning.

tsa mú tsi [-wu-], adj.; straight.

tsa mú Isi ale, adj.; almost straight.

tsa mú tsi he, v. t.; to straighten.

tsa mú tsi láe, v. t.; to straight. ell; straightened.

tsá pi, adj.; puckered, wrinkled. tsá ti, $v$., arlj.; smoothed; oiled ; polished.

tsa' ti, verbal root, or fr. tsa; stick, impale.

tsá ti lie, $v . t$., $f r$. tsati ; to polish.

tsă tse or tsătsi or sătsi, $n$.; a species of goshawk or falcon. known on the Upper Missouni as the "spotted eagle".

tsa twá i ta ma pa, $n$.; the pasque tlower or pulsatilla.

tsa tsú ki, adj, fr. tsuki and ? tsa ; hard to break, not brittle. tsa tsú ki ke, v. t.; to render hard; hardeued. 


\section{tsi}

tsi, n., hypothetical word; foot ; hind paw. See itsi, ditsi, and matsi.

tsi, a prefix to verbs denoting a low or jingling sound. See tsimua and tsitside.

tsi. See tsídi.

tsi dáa dsi, adj., fr. tsidi; yellow. ish ; orange-colored.

tsi dá du i, $v$. $i$.; becoming yellow.

tsí di, adj.; yellow. In compound words, this is often represented by its first syllable 'tsi', which may be a word wherefrom tsidi.is derived.

tsi dí a, same as tsidie.

tsi di á du i, $v$. $i$.; becoming cold.

tsi dí e or tsí di ets, adj.; cold; refers chiefly to reduction of temperature in inorganic bodies.

tsi di e, $n$; cold weather; winter is sometimes so called.

tsi di e ke, $v . t$. ; to cause to be cold; chilled.

tsí di ke, v. t., fr. tsidi; to dye of a sellow color.

tsí di še pi, $a d j ., f r$. tsidi and sipi; bay; said in describing horses.

tsi kó a, $a d j$.; having a marked but not unpleasant taste, sweet, salty, savory.

tsi kó a de, adj.; almost sąty, having a slight saline taste; said of such "alkali springs" and creeks as have water not very strong or unpalatable.

tsi ko á dsi, adj.; sweetish.

tsi ko á du i, $v$. $i$.; becoming sweet; said of coffee which is being alternately sweetened and tasted.

\section{tsi}

tsi kó a ke, v. t.; to sweeten; sweetened.

tsi mú a [-bua], $v$. $i$. and $t ., f r$. mua; to jingle, as metaliic pendants, steel chains, etc.

tsi pa, $n$. ; a marmot; a prairiedog.

tsi pa liu sín ti, $n$.; the burrowing owl, which dwells along with the prairie-dog.

tsí pa tso pe, $n ., f r$. tsipa and ? tsope; the striped marmot, Spermophilus tridecem-lineatus.

tsi pi, $v . i$; to sink, to sink in water.

tsI pi de, $v$. i. ; almost sunken, sinking but rescued in time.

tsî pi ke, $v$. $t$.; to cause to sink; to scuttle, overload, or upset a boat aud make it sink.

tšr př ti, $v$. $i ., f r$. tsĭpi ; to be iu a condition to sink, or ready to sink; said if something falls on the surface of the water, and it is yet uncertain whether it will sink or not; said of a river-bank which is being gradually washed away.

tšr pr ti de, $v$., adj.; nearly in a position to fall upon water; said of portions of a river bluff' that are cracked off and ready to topple, or of anything in danger of falling on water.

tš př ti ke, $v$. $t$.; to cause to fall upon water; to place in a condition farorable to sinking.

tsi ta, $n$.; the tail of a quadruped.

tsí ta si pi sa, $n ., f r$. tsita and sipisia; the black-tailed deer, $\mathrm{Cer}$. vus macrotis.

tsí ta tạ ki, $n$. , fr. tsita and tạki ; the white-tailed deer, Cervus virginianus. 


\section{tsí}

toi tsi de, $v$. $i ., f r$ tsi and ide; to whisper.

tsí tslia, n.; the "prairie-Len" of Western Dakota-the sharptailed grouse, Pedioecetes phasianellus var. columbianus.

tsí tslía do lipa ka, $n .$, fi. tsitska and dolipaka; the Prairiehen People, one of the heredi. tary bands or totems of the $\mathrm{Hi}$. datsa tribe.

tsi tska ic ti a, n., fr. tsitska and istia; the sage-hen, Centrocercus urophasianus.

tsi tú ki, adj.; turned up, pugged. tskạ pi, verbal root; denotes pressure on a small surface; pinch, squeeze, poke.

tská ti, verbal root; pass or force through an aperture.

tski ti, verbal root; denotes pressure ou a small surface from different directions; strangle, shear, ete.

tskí pi, rerbal root; bend, fuld, double. See datskupi and patskupi.

tsó hi, adj.; pointed, tapering.

tsó hi lie, $v$. $t$.; to point, to taper.

tsó lia du i, $v$. i., fr. tsoki; be. coming hard, solidifying, con. gealing.

tsó ki, adj.; hard; resisting pressure, but not necessarily hard to break.

tsó ki he, $v$. $i$. and $t$.; to harden. tsó ki ke, $v$. $t$.; to harden by baking or otherwise; hardened by any obvious cause or process.

tsó pe, $v$. $i$.; to make a chirping or smacking sound.

tsu, n.; half; side; division; compartment.

tsu, adj. (radicle); smooth, flat.

tsí a, adj.; narrow.

\section{tsiú}

tsú a de, adj.; almost narrow enough.

tsu á dsi, adj.; narrowish, seem. ingly narrow.

tsín a he, adj., ? fr. tsua ; synonymous with tsohi, which may be a contraction of tsuahe.

tsí a ke, $v . t$.; to make narrow. tsu á ta, $n$. ; brains.

tsú he, $v$. $t ., f r$. tsu; to divide into two parts; to halve.

tsu i tá dó ta du, $n_{\text {., }} a d v$, fir. itadotadu; bottom-land on the near side of a river; in the bot. tom land, ete.

tsu i ta dó ta ko a [-Iota-], $a d v$. ; at or on the portion of bottom-land or flood-plain on the near side of the river, "on the point this side".

tsu i ta ó ka du [-ru], $n ., a d v$, $f i$ itaokadu ; the part of the bottom-land beyond a river; on the opposite side of the river in the bottom.

tsu i ta ó la lio a, $a d v$.; at or in the bottom on the opposite side of a river.

tsí kan, adj.; flat, as low ground.

tsín lia, adv.; at or in the bottom. land.

tsú ki, adj., same as tsoki.

tsí ta, $n ., a d v$. ; a half; the side of a house; an apartment; in an apartment.

tsíl ta he, v. t.; to break into balves.

tsí ta ka, $a d v$.; within a balf or portion ; in oue side.

tsú ta ta, $a d v$.; toward one side; toward one half or portion.

tsu tsú lii, $v$. $i$; to rattle or stamp loudly.

tsiu tsu te, adj.; smooth to the touch, soft; also tsutsuti. 


\section{ṫ̇é}

tise se, $n$. ; the large wolf.

tsé sa do lipa ka [-mo-], $n$, lit., Wolf People; the Pawnee Indiaus.

tșé sa ma sii, $n ., f r$ t tsesia and masis; a gray blanket.

t甶 a, interrog. adv.; nearly syn. onymous with to.

tú a ka, interrog. adj., fr. tua; how much? how many?

tí a ka duk, $a d v$., fr. tuaka and duk; how long heuce? how many days or nights hence?

tú a ka ruk, adv., same as tuakaduk.

túa a ka se du [-ru], interrog. $a d v ., f r$. tuaka and sedu; how long ago? how many days ago?

tú a lagts, when tuaka stands alone as in interrogative it takes this form.

đú a mi, interrog. $a d v ., f r$. tua and $\mathrm{mi}$; how many?

tú a wits, same as tuami, with terminal ' $t s$ '.

\section{u.}

I, $v$. ; to wound; to be wounded.

$\mathbf{u}$ á, $v . t$. ; to envy; he envies.amáts, I envy. adáts, you envy. uáts, he envies.

í a, $n$. ; a wife, a wife by actual marriage; not perfectly synonymous with itadamia.

í a he, $v$. $t$.; to marry. ( ( 203).

u a hé lae, $v$. $t$.; to cause to marry, to give or take in marriage; said usually of the female.

ii a ke, $v . t$.; to cause to be a wife; married.

u ă lipi, v. $t$.; to smash by shootiug.

\section{úlii}

í a ka, n., ? fr. ua and ika; a man's brother's wife.

í a lii, n.; anything used as bedling, except a pillow; a mattress, sheet, blanket, robe, or skin used as bedding.

́n a ki ta tsi, n., fr. uạki and lạtsi; a mattress; a tick.

u á lisa, $v$. $i$. and $t$., fr. ná; to envy habitually, to be of an envious disposition.

u á ti, v. t.; to ridicule.

u a di kisa, $v$. $t$.; to ridicule unreasonably or habitually.

ú dsa du i, $v$. $i$.; drying, becom. ing dry.

í dsi, $a d j$; dry, devoid of moisture; thirsty.

il dsi de, arlj.; nearly dry.

n dsi lie, to canse to dry, to place before a tire to ary; dried. u e, v. $i$; to boil. See millue. ú e he, $v . t$.; to boil; he boils. í e tsa, n.; metal of any kind ; coin ; recently applied to money of any description and to the unit of our money, a dollar.uetsa duetsa [luetsa], one dollar. uetsa topa, four dollars. netsa itatsuhe, half a dollar.

ú e tsa hi šr" sii, $n$. (hisisisi, red. dish); copper.

u e tsa i du ti, $n ., f r$. uetsa and iduti; a bridle-bit.

u e tsa kán' ti, $n$. (káti, true); gold.

ú e tsa ma i kta de ${ }^{\prime \prime}, n ., f r$. netsa and maiktade; a nail.

u e toa sí di, $n$. (s̈idi, tauny); brass.

u e tsa ji pi saa, $n$. (s̈ipis̉a, black); iron.

í hi, $n$. ; American antelope.

ú lii ma du ti, n., lit., antelope food; the prairie sage, Artemisia. 
úi

í i, $n$.; paint for the face, rouge, vermilion.

ú i $\mathbf{i} \mathbf{s i}, n ., f i$. ui and is̉i ; a paintbag, a smail embroidered bag for holding vermilion or other paint for the face.

ú ka ki, $v$. $i$., ? fr. kaki ; to roll, as a borse rolls himself on the ground.

ú ka tạ la ni, $n$. See Local Names.

í ka ta lii, n., fr. uki and ataki; a white earth which these Indians use in decorating their bodies.

í ki, $n$. ; indurated clas, compact earth of uniform appearance.

ú ki a tạ lí, same as ukatạki.

ii ma ta, $n$.; the south, land south of the Hidatsa buntiug. grounds.

í ma ta lia, alle; toward the south.

í Ina la ko a, adr, ; at the south.

í ma ta ta, adv.; southward, looking or moving south.

iu sa ti, $n$.; east, land east of the Hidatsa countrr.

ú sa ti lia, $a d v$.; eastward, toward the east.

ú sa ti ko a, adv.; at the east, in the east.

\section{$\mathbf{z}$}

í sa ti ta, adv.; facing the east.

í si, $n$. ; the anal region.

í ti, $n$.; base, bottom; root or larger extremits.

í ti lia, $a d v$.; toward the base or bottom; qualifies rerbs denoting motiou.

iI ti du, adv.; in the base, bottom, or root.

il ti ko a, $a d v$.; at the base. utikoa and utidu are often used in the sense of near, beside, or $a d$ joining.

í tsi tsa, $n$; ; variety of change. able weasel, or so.called " ermine".

u zi a, v.t.; to pay a visit; to meet, to encounter.

\section{w.}

w. Words heard to begin with the sound of $w$ may be found under m. ( $($ I $5,20,21)$.

\section{z.}

z. No words have been noted as beginning with $\mathrm{z}$. 


\section{LOCAL NAMES.}

The names of some localities known to the tribe are here given together for convenience of reference. The translations are in italics.

á di saa i ta pa" his, $f r$. adis̀a, ita, and pahi ; Song of the Ravens or Singing-place of the Ravens; a high butte situated between the Missouri and Little Missouri Rivers, west of Fort Berthold.

a ma dé ta ku si" lis, fr. amadeta, a k Il, and sidis ; Tawny Bluff; a prominent river bluff on the south side of the Missouri, about fifteen miles below the mouth of the Yellowstone.

a ma de ta ma pa" his, $f r$. amadeta and mapahi; Song Bluff; a prominent point on the Missouri, below the last.

a 11 ic pu sá ’à, $f r$. amaicpu and sasa; Forked Hill-top; a high butte south of the Missouri in the neighborhood of the upper Great Bend.

a ma mạk i má ka da, Lands Crossing One Another; the lower Great Bend of the Missouri, near Fort Thompson. The derisation is indicated in the word makj. makadaha, which see.

a mai ti, The Missouri River. Some of the tribe say that the name comes from ama, earth, and alludes to its muddiness; others thiuk it is from mati, a boat, and alludes to its navigability.

a ma" ti a clu sá sà, fr. amati and adusasa; Fork of the Mis. souri; Milk River is sometimes so called. a má ti ka za, fr. amati and kaza; Litile Missouri River. The English name is a literal translation of the Hidatsa.

a már ti pa" du is, $f r$ amati and padui; Short Missouri; a small stream entering the Missouri from the south, above Fort Berthold.

a ma tsí di o du toi [-tsis], fr. amatsidi and odutsi; Ochre Mine; a place southeast of the mouth of the Yellowstone, where a yellow mineral pigment is obtained.

a pá di a zis', $f r$ apadi and azi ; Porcupine River; a stream entering the Missouri in Montana Territory.

dă lipi tsa" tu a du a má lais̀ [nă-], fr. dalipitsi, atu, adu, and amaki; Place Where the Bear's Head Sits; a high bill rising from the plateau, southeast of Fort Buford and north of the Little Missouri.

dă lipř tsi a du a ma" lìis, fr. dalipitsi, adu, and amaki; Place Where the Bear Sits; the termination of a mountainous ridge, immediatels opposite the mouth of Milk Ricer, Montana.

dă lipí Isi a ziș; Bear River; Milk River, Montaua.

dún' ta a zi [-zais], fr. da'ta and azi ; Heart River; the Heart Rirer, which enters the Mis- 
souri from the west, above Fort Rice.

dé zi a zi [neziazis], $f r$ dezi and azi; Tongue River; the Tougue River, a branch of the Yellowstone.

do ki dá lii la pa his [no-], fr. dokidalii, ita, and pahi ; Singing of the Ghosts, or Where the Ghosts Sing; a high pinnacle of red rocks about mid-way between the Little Missouri and Yellowstone Ricers near the point of greatest proximity of the two streams.

hi dai tsal, formerly the principal village of this tribe when they dwelt on Knife River.

hi dá tsa ti, fr. hiclatsa and ati; Docelling of the Hidatsa Indians; the present village of the tribe at Fort Berthold.

lia lia" tu a a lu ta hés, $f i$. haliatua, alu, and tahe; Where the Chippeway was Filled; a locality near the foot of the upper Great Bend of the Missouri.

i lice ti" a a du ta liés, Where Big Forehcad uas Killed; the Tobacco Garden bottom, at the month of Tobacco Garden Creek.

i té ma tse e tsis, $f \circ$. ite and matseetsi ; Face of the Chief; the Black Hills of Dakota.

ma é tsi a nis, fir. maetsi and azi; Knife River; a name applied to two streams, one of which enters the Missouri from the north, above Fort Berthold, and the other from the south, below that place.

ma ka dí sta ti, $f$ r. makadista and ati ; House of the Infunts; a cavern near the old villages on Knife Ricer, supposed to be inhabited by mysterious infauts. ma o dé śa a zi [-me-], fr. maodesa and azi ; Nothing River or Nameless River; an affluent of the Little Missouri, entering the latter about one hundred miles above its mouth.

ma pó lisa a ti, fi. mapokșa and ati; Snake House; a cave near the Missouri Ricer, on the north or left bank, close to Snake Creek. It is said, at some seasous, to swarm with serpents.

ma pó lisa a ti a zi [-zis] Snake House River. So called by these Indians; but Lewis and Clarke have given the name as "Snake Creek", and it has been thus known to the whites erer since. It enters the Missouri five miles east of Fort Sterenson, Dakota Territory.

ma su" ka ak su a ma sís, $f r$. maśukaaksu and amas̉i; Earth. trap, or Eagle-trap, of Coral Ber. ry; a point on the left bank of the Missouri, immediately below the upper Great Bend.

má tạ ki a zis, Dish River; Platte River, Nebraska.

mai tsu a zi [-zis], $f r$ matsu and azi; Cherry River; a stream which enters the Little Missouri from the east, above the maodesaazis.

ma u" pạ ki hún pa i sis̀, $f r$. maupạki, hupa, and isiss ; Like the Handle of a Mallet; a promiuent bluff on the south side of the Missouri, nearly opposite the mouth of npper Knife River.

mi da $\mathbf{i}$ si a mis̀, fr. midaisi and azi; Bark River; a stream which enters the Missouri from the south abore the Yellowstoue.

mi dạ tsa pi a ris̀, fr. midạtsapi and azi; Powoder River or 
Dust River; the branch of the Yellowstone now known as Pow. der River.

mi di ho pá [bidi-], fr. midi and hopa; Sacred, Medicine, or Mysterious Water; the Minnewakan or Deril's Lake, in northern Dakota.

\section{mi di o dá mu a ziśs [bidio-}

nawuazi], fir. midi, odamu, and azi ; River with Deep Spot or Channel. Some say that this name signifies the River that Rises, or River that Deepens, and such may be liberal translations of the word; hence the English names of Rising-water and Tidewater Creek, and the French L'eau-qui-mont. This stream enters the Missouri from the north, about trenty-five miles west of the Grosventre village.

mi dî́ si a zis, $f r$. midi, isia, and azi; Bad Water River; the Muddy, a stream flowing from the north and entering the Missouri about twenty-five miles east of Fort Buford.

mi di tó hi a zis̀, fr. midi, tohi, and azi; Blue Water River; a creek near Fort Berthold to the west.

mi te a tă di lie a zis̀, fr. miteatadike and azi; Box Elder River; a stream entering the Missouri from the sonth, about thirty miles below the mouth of the Yellowstone. mi tsí a da zi [mitsiamazi], prob. fr. mi', tsi or tsidi, and azi ; the Yellowstone River.

mi tsí i ta mi dạ kisisis, $f r$. mitsi, ita, and midaks̉i ; Pali. sade of the Wedge; a high conical hill in the valles of the Little Missouri, some eighty miles southeast of the mouth of the Yellowstone; a prominent land. mark.

Dạ tskạs, fr. patska; the Coteau of the Missouri.

pe de tski" lii i ta a ma sís, Eagle-trap of Crow.(Crop) Breast; the bottom-land in the neighbor. hood of Dry Fork, on the road between Forts Buford and Sterenson.

ta hú i ki sis, fr. tahu and ikisii ; Nest of the Thunder; a prom. inent flat-topped bill lying south of the Missouri, near the amaic. pusiasas.

ti pí a a zisis, or tipíanazis, Mud River; the Big Muddy. River, a stream flowing from the north and entering the Missouri about twenty miles west of Fort Buford.

ú ka ta ka mis, $f r$ ukiatạki and azi; White-earth-River. The White Earth River enters the Missouri from the north in W. long. $102 \circ 30^{\prime}$ (nearly); it was formerly the extreme western boundars of Minnesota Territory. 


\section{ENGLISH-HIDATSA VOCABULARY.}





\section{ENGLISH-HIDATSA VOCABULARY.}

ABASE.

A.

ABAsE, v. t., is̈iake.

AвAsH, $v . t$, itodike, kiitodike.

AвАтікG, par., kadistadui.

ABDones, n., edi.

ABFD, adr., maaduliạpikoa.

ABJECT, adj., adiaśadsi ka'ti.

ABodro, ade., mátikoa, mati ama.

hoka.

AвODE, $n$. ati, atike.

AвоLish, v.t., kideśake.

ABove, pr., ade., aka, akoka.

ABridge, $v$. $t$., kipaduike.

Aвsons, v. t., daliupi, liupi, kida.

liupe.

accelerate, $v$. $t$, kihitale.

Accelerativg, par., hitadui.

Accept, $v$. $t$., dutśe.

Accompany, $v$. t., ikupa, ikupa de.

Accomplished, par., komi, kiko. mike.

ACETAвULum, n., idikiutioki.

ACHE, $v$. $i$., ade, kiadś.

ADD, $v$. $t$., ikupake.

ADHERE, $v$. $i$., kaditskapa.

AdJust, $v . t$., kiksa.

Admire, $v$. $t$., kideta, kidetadsi, ite.

ADUL'T, n., maictia.

Advance, $v$. $t$., kiitsikake.

AfloAt, adv., dakapilii.
ANus.

AfrAID, adv.; kie, kiets.

AFTER, udj., ipita, ipitakoa.

Afterioos, $n$., midimapedupahidaksipi.

AFTERWARDS, adv., ipitadu.

Agrtate, $v$. t., liakahe.

Ago, adr., sedu, tata, tatakoa. See

How and LoNG.

Ahend, all., itekoa, itsika.

Alrke, arlv., mạkseșe, malis̉esadsi, mạkisia. See Equal.

Alive, adj., tétats, hidakatsa.

All, alj., etsa, liakaheta.

ALOFT, ad $\bullet$., hakoka.

ALose, arli., itsạki, mitsạki, șetsạ-

ki, etc.

Also, adv., iša.

Alter, v. t., kiihake, ihake.

AMERICAN, n., maetsictia.

Amidst, prep., dumatadu [nuwataru].

AMple, arj., itski, itskits.

Axecdote, $n .$, mazi.

Axgen, $r . t$., adebeke, da'ta isiake.

ANGLE, n., adupạlii.

ANGLE, $v$. i., muakikidi, muadutsi.

ANGrr, adj., adehe, kiadehe.

Axnihilate, $v . t$., kidesake.

ANother, $n$. , iba, aduihá.

AŇl, n., mapoșakiditi.

ANTElope, n., ulii.

AN'TiQUATE, $v$. $t$., liieke, kiliieke.

ANTLER, n., aziliami.

ANUs, n., uzi.

Note.-There are some Hidatsa words in this section which are not contained in the Dictionary proper. In such words, the accent is indicated; in the others, as a rule, it is not. 


\section{APART.}

Arart, adj., ihadu, ibakoa, mạkihita.

APEX, n., icpu, aduícpu.

APPEAR, $v . i .$, ate, kiate.

Approach, v. t., kiătseke.

Apron, n., iśutipsạki, maiśutipsiaki.

AQUeous, adj., miditsi.

ARE, v., matu.

Arickaree Indians, n., adakạdabo.

ARIse, v. i., iduhi, kiduha, kiduhe. ARISEN, part., kiduhi.

ARI, n., ada, adaaduictia.

ARound, adv., ialialia.

Arouse, $v$. $t$. , itsihe.

Arrange, $v . t$., kikśa.

ARrow, $n$., ita, maita.

ARrow.CASE, $n$, maitáiši.

ARRow-HEAD, n., itahi', maitahi'.

Arrow-Qullls, n., itais̉u, maita. is̀u.

Artemrsia, n., iliokataki-akusipiṡa. See SAGE.

ARTICHOKE, n., kakśa.

AsH, n., misipa.

Ashaned, adj., itodi, itodike.

Ashes, n., midạtsapi.

AsLEeP, adj., bidami.

Assinneboine INDIANS, n., hidusidi.

A's, prep., ka, koa.

ATTEMPT, $v . t$., maihe waihe.

AUGER, $n .$, mída-ikihópike.

AUNT, n., is̉ami, ika, maśawiś.

AURICle, n., akulii, apa.

AUrora Borealis, n., apaliadalia, amasiitakoa-amaliati.

AU'rumn, n., mata. NEx'r -, mataduk.

Au'umnal, adj., matadu.

AWAKE, adj., itsi, hídamitats.

AWL, n., matsito, matsitoictia.

AxE, n., maiptsa, miiptsa.
- Bear.

B.

BАBY, n., makadista, makidaks்i.

BACK, n., isita. - adv., ipita, ipitalu. - AND FORTH, dumaliita.

Backbone, $n$., isítahidu.

BACKWARD, $a d v$., ipitakoa, ipitalia,

isitakoa, isitalia.

BAcoN, $n .$, maṡiitadahitsisiui, śui.

$\mathrm{BAD}, a d j .$, isia.

BAD-LANDS, n., amasiia, amasipe, etc.

BADGER, n., amaka.

$\mathrm{B} \Delta \mathrm{G}, n ., \mathrm{isi}$.

BAKER, $n$., madạ́liapi-akuhídi.

BALD, adj., ada deśa.

BALL, n., mautạpi.

BAND, n., icke, daki.

BANk, n., amadeta, midideta.

Banner, n., madakapilii.

BARGE, n., midamati.

BARK, n., midaisi, midis̀i [bidis̀i].

- v. i., muadaki. - v. t., dah.

api.

BARrel, ., midiope-kakilii.

BARTER, $v . t$., maihu [baihu, waihu].

BASE, n., uti, aduúti. - adj, is̉ia.

Basis, n., matsamidi.

BAsket, n., midạliasi [bidạliaṡi]. BAT, n., išuatisia.

BAтнe, v., midipi, midipike [bidipi], dipi dipike.

BATTLE, n., makimạkia.

BAY, adj., tsidisipi.

BEADs, n., akutohi, maahidulia.

BEAK, n., tsakaka apa.

BEAN, n., amazi.

BEAR, n., dalipitsi. - skIN, dahpitsiodalipi. BEAR's CLAW, dah pitsiicpu. - CUB, dahpitsidaka. - TRACK, dalipitsiti. 


\section{BEAR.}

BEar, v. $t ., \mathrm{ki}$; edede.

BEARD, n., iki.

BEAT, $v$. $t$., diki.

BEAUTIFul, adj., tsạki [sạkits], itetsạki.

BEAvER, n., midapă [bidapă, mirapa].

BED, n., aduliạpi, itaduliạpi, maaduliạpi. Bedorxg, uaki.

BEEF, n., mité.idluksiti.

BEetle, n., pedakula'te.

BEFOOL, v. t., kimadulitake, madulitake.

BEFORE, prep., adv., itekoa, itsika. BEG, v. t., kadi.

BEGGAR, n., akukádilisa.

BEHIND, adv., ipitadu, ipitakoa.

BEnOLD, v. t., ika, ikada', ikaka.

BELCH, v. i., kipśuki, pśuki.

Believe, $v$. $t$., idie.

BELL, n., maitamua.

Below, prep., adv., miktata, miktakoa, utikoa.

BEL'T, n., maipạsaki, maikipaśaki.

Bexp, v. t., dutskupi, kipatskupi, kipatskupike, patskupi, șakupike.

BExT, part., kipạtskupike.

Benumb, $v$. $t$, otsliamike.

BERDACHE, n., miati.

Beside, adv., utikoa.

BESPAT'TER, $v$. $t$., opape.

Bewitch, $v$. $t$, , lusku.

BEyoxd, prep., itaokadu, itaoka-

koa, oka, okadı, okakoa.

BID, $v . t$, iske.

BIG, adj., ictia.

BIGGER, adj., ictia itaokakoa.

BIG-HORs, $n$, azictia.

BILlow, n., mididạliisisi.

Bisd, v. t., duti.

BIRD, n., tsakaka.

Bisect, $v$. $t$., dopahe, dopaheke.

Bison, n., mite, kedapi.

BIT, n., kausta alipi, uetsa iduti.
BONE.

Bite, n., adudátsa. - $v$. t., datsa, datạpi [latạpi].

Bitter, adj., adui [elui].

BlaCk, adj., sipi, sipișa. - PAINT, amasipișa.

BLACK·BIRD, n., tsakaka sipis̀a.

BLACK-DYE-STUFF, $n$., isipisake.

Blackes, $v$. $t$., sipilue, sipisake.

Blackexisg, part., sipisadui, kisipisadui.

BLACKFEE'I INDIANS, n., itsisibisa.

BLaCkIxG, n., midahupa-ikitsatike. Blackish, adj., sipisadsi.

BLADDER, n., úsikadalii.

BLAxke'r, n., itaṡi, mas̀i, uạki.

BLfach, $r . t .$, iliotakike, kiatąike.

BLenchisg, part., atahadui, iliotakadui.

BLEED, $\imath$. $i$, idihu.

Blivo, arj.. ista desa.

BLrOD, n., idi.

Bloody, arj., iditsaki.

Blossoy, n., odakapạki. - v. i., dakapaki, kidakapạki.

Blotched, adj., pulii.

BLow, $v$. t., kadse, katsi.

BluE, adj., tohi. - DYE-STUFF, $n$., itohike, ikitohike.

Butisn, adj., tohadsi, tohisa.

BLufF, $\varkappa$., amadeta, amadetakumakn, amadetakulialii.

BLUx', adj., śasuki.

BoAr, n., massiitadalipítsi-kédapi.

BOARD, n.. midatsuka.

BoA'T, n., mati. SAIL-BOAT, hut. simati.

BoDkIN, n., matsitoka.

BoDy, m., ilio (lio, dilio, malio).

BoIL, n., adnitúrli, adupua.

Borl, v. i., midue [bidue]. - v.t., miduehe, midueke, kimidueke.

Bold, adj., kiadetsi.

BoLt, n., ikipatạki, maíkipatạki.

Bore, n., hidu. 


\section{BoNinet.}

Bonvet, $n$., apoka, mía-apoka.

Book, $n$. , mamadaki.

Boot, $n$., midahupa [bidahupa].

BORDER, $n$., deta, adudeta.

Bosom, n., imạki.

BOTTLE, $n$, midiaduiisi [bidielui-]. BoтTом, n., mikta, uti; tsuka, tsuitaokadu, tsuitadotadu, etc.

Bow, n., itadulia, midulia.

Bowels, $n$., sipa.

BowL, n., matsamidikaza.

Box, $n$., iope, maiope, midaiope, midiope [bidiope].

BOX-ÉLDER, n., miteatadike.

Boy, $n$, makadistamatse.

BraID, n., adaiduti. - v. t., dak. tsuti.

Brain, n., tsuạta.

BRANCH, n., adusiasia.

Brass, n., uetsašidi.

Brave, n., maadukiadetsi.

Brave, adj., kiadetsi.

BREAD, n., madạhapi, madạliapihopi, madạbapitsoki.

BreaK, $v$. $t$., adaliolii, daliolii, dakaliolii, liolii, duliolii, paliolii [nakaliolii, ruliolii], kiadaliolii, kidakaliolii, kiduliolii, kidulioliike, dakata [nakata], dupi.

BREAST, n., imạki, a'tsi.

BREECH.ClOTH, $n$, idiipsaki.

Brethren, $n$., itametsa.

BrIdLe, $n$., iduti.

BRIGHT, adj., itsitsi, kaditska, ataise.

BRIGHTEN, v., itsitsike, kadítskake, kiitsitsike, kikaditskake.

Bring, v. t., akhu, kiakhu, akikahe.

BRIS'TLE, n., hi.

BRITTLE, adj., tapa, tapai.

BROAD, adj., șoki, ṡas̉uki.

Brook, $n$., azikaza.

Brooy, n., mašiailia.

Brotr, n., hupa.
CANDlestick.

Brother, $n$., iaka (miaka, diaka), itadu (matadu, ditadu), itametsa (matametsa, ditametsa), itsuka (matsuka, ditsuka). -IN-LAW, ida'ti, išikisisi.

Brutse, n., odaksạai. - v. t., daksàki, kidaks̉aki.

BuCK, n., tsitataki kedapi.

BUCKET, $n$, midąia.

Buckskin, n., tsítatạki-odálipi, atisia.

Buffalo, n. See Bison.

BUfFALO-BERRY, n., mahisii. TREE, mahisia.

BuFFalo-RoBE, $n$. , dalipl, itaṡi, maśi, mite-odalipi [bite-oralipi].

BuLKY, adj., titsi.

BULL, $n$., kedapi.

BULlet, $n$., adupoadui.

BundLe, $n$., makidaksii. - v.t. kidaksii.

BuRN, $v$. $t$, adalia, adakiti, adapapi.

BuRs'T, $v$. i., kiduta.

Butcher, n., akukitahe, - v., hakạtsi, kibakạtsi.

ButTer, n., a'tsimidi.tsáda.

Butrox, n., ikatipe, imạkikatipe, maikatipe. - v. t., katipe.

Bur, v. $t$., maiku.

\section{C.}

CACHE, $n$., amaisisi, kohatiisi.

CACTUS, $n$, patskidia, patskidiaoka. CAKE, $n$, madạ́liapi.tsikóa.

CALF, n., daktsidi [naktsidi], miteidaka, mitekaza.

Calico, n., akupuzi, mašiiliipuzi.

CAMBRIC, $n$. , mas̉iililiapi.

CAMP, n., ati, adati.

CANDLE, $n$., midaiamaliati.

CANDlestrck, $n$., midaiamaliatiioki, midaimaliatiioptsati. 


\section{CANDY.}

CANDY, n., matsikoa-hatski, matsikoa.puzi.

Cannon, $n$., midúlia-aduhópi-ictia. Canoe, $n$. , midaduetsa [bidaluetsa].

CAP, n., apoka.

Captive, n., da'ki.

CAPTURE, $v$.t., akikahe, kiakikahe, dutse, kidutse.

Caress, $v$. $t$., kidạlipa.

Carry, v. a., ki.

CART, n., lialiátua-midiúkaki.

CaT, n., puzike, itupa.

Caterpillar, $n$., midakuduti.

Catkis, n., masuakaza.

Cave, n., ama-aduhópi.

Cease, $r$., haka'ta, kihaka'take.

Cedar, n., midahopa.

Ceyetery, n., dokteodusia.

Cextral, adj., dumatakoa.

Centre, n., dumata ka'ti.

Ceremony, $n$., dalipike, paduididi.

Certain, adj., ka'ti, ka'timats.

Chark, n., midaiakaki.

Chuxge, $v$. ., ihake, kiihake, katika.

Channel, $n$., odamu [onamu].

CHAP, $x$, adapapihe kiadapapike.

Chari, n., hopa, mabopa.

Cheap, adj., ímasi-kaústa.

CHeck, $r$. t., kiliaka'take.

CheCker, $v$. $t$, mạkiapeke.

Checkered, adj., mạkiape.

CheEK, n., dodopa.

Cherry, $n$., matsu. - tree, matsua.

Chew, v. t., dasia, duti [ruti].

Cheyenne Indians, $n$, itasupuzi.

Chicken, n., tsitska, masiitatsakáka-idaka.

CHIEF, $n$., matseetsi.

Child, n., daka, idaka, makadista.

ChILL, $v$. $t$, hapake, kibapake.

Chunvey, n., atisi, aduue.

ChIN, n., ika.

Chippeway Indiaxs, n., lialiatua.
Companion.

Chirp, $v$. $i$., odaki.

Сноке, v. t., dota dutskiti, dutapi.

Снор, $v$. $t$., daktsạki [naktsạki], dakamitsi, kidaktsạki.

CrrCle, $n$., adukakilii.

Circular, adj., kakilii.

Clasi, n., matoke.

Clan, n., daki.

Clarify, $x$. $t$, dehike, kideliike.

Clsw, n., tsakaka itsi.

ClaY, n., ama, uki.

Cleas, v. t., dusiuki, dutskiši, hat. sa, ilia kideșake.

Clear, adj., delii, oliati.

Cliff, n., ama daliạpes̉i.

CuIP, $x$. t., datskiti.

Clock, n., midiikikiski ictia.

Cluse, $v$. t., mạkipatạki.

Close, adj, atse.

Cloth, n., masiiiliitatsi.

Clothe, $x$. t., ukạta, itulii okạta.

Crothes, $n$, ilioisi.

Clothes pis, $n .$, mailutskạpi, maitulipi-dutskạpi.

Crovd, n., apalii, apalii-adusipisisa.

Cloved, adj., liapati, liapatikșa.

Cleb, n., mídakaza-títsi.

COAL, n., amaadalia.

Cost, n., itulii, matsé-itulii.

Cos, n., hupa, kóhati-hupa.

Cochineal, $n$, ihisike.

Cock, n., mastiitatsakaka.

CoffeE, $n$., amazisipisia, maadaha; midisipia [minisipisisa], matsikoa.

CoHere, $v$. $i$, mạkikaditskapa.

CoLv, udj., ak hapa, hapa, tsidia.

Cosn, n., ikidulioki, maadaikidulioki, maikidulioki. $-v$. t., du. lioki, kidulioki.

Conbat, $n$, makimạkia.

Cone, $r, i$., hu, ate.

C'ommaxd, $v$. t., iske, śke.

Companion, $n$. , idaķoe (madakoe, didakoe), iko'pa (mako'pa, diko'pa). 


\section{COMPLETE.}

Complete, $v$. t., kikomihe, kiko mike.

CoMple'sed, part., komi, kowits.

Comrade, $n$. See Companion.

Confine, n., adudeta, deta. $v$. t., duti.

Conical, $a d j .$, tsohi, tsuahe.

Consume, v. t., kiadaliake, kiadakiti, pe.

Consured, part., kiadalia.

Contais, $v$. t., itski, matu.

Contest, $v$., mạkia, mạkieke.

Con'rnue, v. $i$., daka, hidakatsa.

Con'rract, v. t., kikadistake, kikaustake.

Converse, $v$. $t$., ikúpa-ide, makiide.

Convex, adj., poaduadsi.

Cook, n., akumadihe, maakumadihe. - v. t., madihe, otihe, otike.

Cooked, part., oti.

Cool, v. t., kạtsihe, tsidiake, etc.

COPPER, $n$, netsahisisisi.

Copse, n., mida-šikía, mida-sípa.

Copy, v. t., kutski.

Coral-Berry, n., maśukaaks̉u.

- BUSH, maṡukaáks்ua.

CORD, n., as்n, matạlipi.

Cors, $n$., hopati, kohati, madạskihe, matua. - coB, hupa. - Husk, hopatis̄i. - STALK, kohatia. MEAL, kohatipi.

Corpse, $n$. , dokte [nokte].

Corpulent, adj., idipi.

Cos's, n., imasii.

Costux, adj., ímaši-ahú.

Cottronwood, n., maku, makukazi.

Cough, $v$. $i$, hua, huaks่a.

Couns, v. t., kidumi.

Country, n., ama, itama.

Court, $v$. $t$., akape, mia àkape.

Cover, n., iitipe, is̉i, maisis.

Cow, n., mite, mašitamite.
DAMAGE.

Cowardly, adj., kíadetsitats.

Coyo'te, n., motsa [lootsa].

CRACK, $v$. $i$, duta.

Crackers, n., madạliapitsoki.

Cradle, n., maidakudsi, maikidakudsi, makadistaidakudsi.

Crane, n., apitsa.

Craze, v. t., kimadaliạpake, madaliạpake.

Crazy, adj., madaliạpa.

Crease, $n$., aduliakupi, maaduliakupi.

CreEK, $n$. , azikaza.

Creep, v. $i$., miti.

Cree Indians, $n$. , sabe.

Crescent, n., midikidahe.

Crimson, adj., his̉adsi. - DYESTUFF, $n$., ihisadsike.

Crooked, adj., ṡzkupi.

Crooken, $v$. t., kis̉akupike, ṡakupihe, sakupike.

Crop, $n$, ilii.

Uross, adj., atska. - v. t., akạlipi, tadi.

Crow, n., pedetska.

Crowd, v. t., lialiuake, kilialinake.

Crow Indrans, $n$, kiliatsa.

Cry, v. i., imia. To cause to -, imiake, kiimiake.

CuB, $n$, idaka.

CUP, n., midiihike.

Cupboard, n., matạkiadukidusia. Curf, v. $t$, deśake, kides̉ake, kit. sạkike, tsạkike.

Curly, adj., sikia.

Currant, n., mitektsatsa.

Cut, v. t., daktsạki, datskiti, idalipi, pamitsi, patsạki, kidaktsạki, kidatskiti, etc.

\section{D.}

Daкота INDIaNs, n., itahatski. Davrage, $v$. $t$, is̉iake, kiisiake. 
DAMP.

DAMP, adj., adạtskivi.

DANce, n., makidiši, paduididi. - v. $i$., kidisi.

DARK, adj., ha'peśa, sipisiadsi.

DARKen, $v$. $t$, ba'pesंeke, kiha'peseke, aduoktsihe, sipisiadsibe.

DARKENING, part, ha'pesadui, ki. ha'peșadiui.

DARKNesS, n., aduoktsi.

DaUB, $v . t$., ipkiti, opape.

DAUGHTER, n., ika (ka, maka, dika).

DAws, n., ata, atade, kiduhakute.

DAY, n., mape. BY DAY, mape. du.

DEAD, adj., te, tets.

DEAF, adj., akulii deśa.

DEFaSE, $v$. $t$., kiisiake.

DECEITFul, adj., mitapạksia.

Decerve, $x \cdot t .$, mitapa [witapa], mitapadsi.

DECREASE, $v$. t., kadistake, kaustake, kikalistake, kikaustake.

Decreasing, part., kadistadui, kaustadui, kikadistadui, kikaustadui.

DEEP, adj., damu [nawuts].

DeEpen, $v$. $t$., damuke, kidamuke.

DEER, $n$., tsitaśipisia, ts̉itataki.

Degenerating, part., isiadui, kiisiadui.

DEITY, n., itakatetaś, itsikamahi. dis.

DElirious, adj., madaliạpa.

DeNUdE, $v$. $t$, adaliape.

Deposit, $v$. $t$., dus̉e, kidusia.

DERIDE, $v$. $t$, uati.

Descend, $v$. $i$, miktata de.

DESERT, $n$., amaisía.

Destror, $v$. t., kides̉ake, kitahe.

DETER, $v$. $t$., kihaka'take.

Devour, $v$. $t$., kiduti [kiruti].

DiE, $v$. $i$, te, ta, tebe.

Different, adj., iha.
Down.

DIRT, n., ama, ilia.

DIRTr, adj., amatsaki, iliatsaki, tsadatsaki, kiamatsaki, kiiliatsaki.

DirTy, $v$. $t$., amatsakike, iliatsakike, tsadatsakike, kiamatsakike, etc.

DISCover, $v$. $t$., odapi, kiodapi.

DISEASE, $n$., ilioade, mailioade.

Dish, n., matạki.

Dishonest, adj., ašádilișa.

DIslike, $r$. t., ikúpade, iku'padsi, kidésitats, kiiku'pade.

Dislocate, $v$. $t$., kipsiuti, pśuti.

Displease, $v, t$, da'taisiake [na'. taišiake].

DISREGARD, $v, t$, íkatats.

DISSIPATED, $v, t$., maduliạpakṡa.

DISTANT, adj., tisia.

Distend, $x \cdot t$, dakapusii, kidakajusi.

Distress, $v$. t., kida'taisiake.

DIVIDE, $v \cdot t$. - IN TWO, dopake [nopake]. - IN THREE, damike [nawike]. - IN Four, topake, kitopaheke, kitopake. -, v. i., śasa.

Diverge, $v$. $i$, liami [liawi].

DIVORCE, $v$. $t$, haheta, hahetake.

DIzz 5 , adj., tsahidumidi.

Do, $v$., ha, he.

DUE, n., tsitatạki mika.

DoG, n., maśuka, pedakuduti.

DoG BAND, n., mas̉uka icke.

DoGWOOD, $n$, matsuotạka.

JOLL, $n$., makadistake.

Dollar, n., uetsa-duetsa [luetsa].

DoMrnoes, $n$., hiduimakia.

DONE, part., komi [kowi, kowits].

Door, $n$. , mide [bide].

Double, $v . t$., patskupi.

Dough, $n$. , wadạ́liapi-tsa".

Dove, n., mádaitakupeic"ki.

Dows, adr., miktádu [wiktaru], miktakoa [wiktakoa], utikoa. 
DownwaRd.

DownwarD, adv., miktata [wikta. ta], utilia.

Doze, $v$. $i$, hamide, hidamide.

DRAG, v. $t$., duliade.

Drain, v. $t$., daliupi, kidaliupi.

Dresir, $v$. $i$. masiade.

DREDGE, v., duto'ti. .

Dregs, $n$., pedi.

Dress, n., ilioisii. - v. t., okata.

DRIED, part., kiurisike.

Drink, n., oze. - $v$.t., hi, midihi.

Drop, $v$. i., pạti, kipạti. - v. t., pạtihe, pạtike, kipạtike.

Drowned, part., tsipạk tets. See tsipi.

Drowsy, adj., hamicti, hidamicti.

DRUM, n., midạlia. - strck, midạliadiki.

DrUNK, adj., madaliạpa.

DRY, adj., udsi. - v. i., udsike, kiudsike. - ING, part., udsadui. Duck, n., miliaka.

DuLL, adj., saśuki, soki. - v. t., kisokike.

Dung, n., aduedi, pedi.

During, adv., du, sedu. - тHE AUTUMN, matadu. - THE COMING AUTUMN, mataduk. - THE DAY, mapedu. - THE NIGHT, makudu, oktsiadu. - THE SEAsoN, kadudn. - THE SUMMER, adedu. - THE WINTER, mada. du.

Dusk, $n$. , oktsiade.

Dust, $n .$, midạtsapi.

DWELL, $v$. i., amaki, amakadaki.

DYE, v. $t$. - BLACK, sipis̀ake.

BLACKISH, sipiśadsike, kisipisadsike. - BLUE, tohike, kitohike. - BLUrsH, kitohadsike, kitohișike. - RED, hisike, kihisike. YELLOW, tsidike, kitsidike.

Dye-STUFF, $n$. See names of differ. ent colors.

Dyixg, part., tade, tadets.
ENCIRCLE.

\section{E.}

EAgle, n., iplioki, unaisu, tsatsi.

EAR, n., akulii, apa. - OF CORN, hopati.

EARLY, $a d v$., itsikakoa, kiduhaku. terlu.

E $\Lambda$ RTH, n., ama.

EARTHWARD, adv., amakoa, amata.

EAsT, n., uṡati. - ERN, adv., uśatikoa. - WARD, uśatilia, uśatita.

EAT, v. t., duti, kiduti, pe.

EATER, n., akudúti.

EвB, v. i., kidamoki, kiduliemi.

EDGE, n., aduaptsa, adudeta, deta. EGG, n., tsakakadaka.

EIGHт, adj., dopapi [nopapi].

Елgнтн, adj., idopapi.

Eightнly, $a d v$. idopapidu.

Eighteen, adj., alipidopa.

Ergнту, adj., dopapitika.

ELas'ric, adj., dupupi. - GUM, n., idupupi.

Eцвоw, n., is̀pạlii, (mis̉pạlii, dis̀. palii).

Eleven, adj., alipiduetsa [alipiluetsa].

ELK, n., madoka [maroka].

ELm, n., midai.

ELSEWHERE, adv., ihadu, ihakoa.

Euactated, adj., liadaliiksंa.

EMbERs, n., midahapokśa.

Eumrace, $v$. $t$., kidạlipa.

Eurbroidery, n., adupúdsike, masiiptse.

EunkgE, v. i., ate, atehe.

EME'í, $n$. , maikadé.

Eurpty, v. t., kidaliupi, kipahue.

ExсAMP, $v$. $i$, atihe.

ENсналт, v. t., duśku.

ENCIRCLE, v. $t$., dutskiti, iahahia. 
END.

Evd, n., ạtạka, icpu. At END, ạtạkakoa.

ENEMY, $n$, maiha.

ENEMYY-WOMAN BAND, n., maihamiaicke.

Exlarge, $v$. $t$., ictiake, kiictiake. Exough, adv, ahu, komi.

ENRAGE, v. t., kiadeheke.

ENTER, $v . t$., midedi [bidedi], pi.

Extire, adj., liakaheta.

Exvy, $v$. $t$., uá, uaks̉a, kiná.

EQUAL, adj, mạksia, mạkšiaka, seka. - NEARLY, mạksiade, maksiakadsi. See Alıke.

EQUALIzE, $v$.t., kimạks̉es̉eke, mạkses̉eke, mạk siakake, etc.

Erase, $v$. $t$, adaśuki, dusuki, kiadasiuke.

Ermine, $n$., utsitza.

Evening, $n$., oktsiade, o'pa. Next -, o'paduk.

Exanive. $v$. t., kikiski.

Excavate, $v$. $t$, ho'pike, kiho'pike.

Exhaust, $v$. $t$., kidaliupi, kikomike.

Exнівіт, v.t., atehe, ateheke.

Expose, $v$.t. $\}$ kiatehe, kiateheke.

ExTEND, v. $t$., kidakahe.

Exteruinate, $v$. $t$., kidesiake, etsa kidesake.

External, adj., atasiikoa.

Extinguish, $v$. $t$, katsi.

Extract, v. t., daśku, dusika, paśku.

EYE, n., išta. - LASH, istapi. LID, istadalipi. - WASH, istaoze. 一, WHITE of, isitaduiliotạki.

\section{F.}

FACE, $n$. , ite.

FAcrivg, adv., ta. See iteakata and iteamata.

FAIR, adj, delii, oliati.
Fine.

Fall, $n$. See Autumn. - $v . i$, liue, pạti, kipạti.

FAs, n., maikidakndi. - $v$. t., dakudi, kidakudi.

FAR, adv, tis̉a, oka tis̉a.

FARM, n., adukạti. - v. t., amaoze.

Farder, n., akuamaoze.

FAs', adj, hita, tsoki.

Fasten, $v$. $t$., duti, kitsokike.

FAT, n., sui, tsada. - adj., idipi.

Father, n., ate, tatis.

Fatigue, $v$. $t$, daheka'tike, kidaheka'tike.

Fatugued, adj., daheka'ti.

Eatten, $v$. $t$., idipike, kiidipike.

FatTenisg, part., idipadui, kiidipadui.

Fuws, n., tsitatạki idaka.

Fear, $v$. $t$, kie.

Feast, n., maihadi.

Featner, n., hi, tsakakahi. See Quills.

Ffed, $x$. $t$., kidutike, madutiku.

Female, n., adumíka, mia, mika, mikạts.

Fevur, n., idlíkihidu.

Few, adj., kausta.

Fibrous tissue, n., matsua, matsuapạkis̄i.

Field, $n$., adukạti.

Fierce, adj., atska, atskaksia.

Fifteen, adj., alipikiliu.

Fifteenth, adj., ialipikiliu.

FifTH, $a d j$., ikiliu.

Fifthly, $a d v$, ikiliudu.

FIFTY, adj., kiliuapitika.

Fight, $u$. See Battle. - v. $t$, kiạmakia [kiwạkia].

Figured, adj., puzi.

Fill, $v$. $t$., kimaazike, maazihe, oze.

Find, $v$. $t$., odapi, okipapi.

Fine, adj., tamulii [tawulii], tamuhiidi. 


\section{Finger.}

Finger, $n$. , sakiadutsamihe, is̉akiadutsamihe. - NAIL, sakiicpu, ișąkiicpu. - RING, salkioptsati. LitTle -, sakikazi. MIDDLe 一, sakidumatadu. RING, sakikazi-utjdu.

FinisH, v. t., komihe [kowihe], kikomilue.

Fire, $n$., midaha. - PLACE, aduue. First, $a d j$, itsika.

Firstuy, $a d v$, itsikadu.

Fish, n., mua. - $v$. See ANGLE. - HоOK, maidutskupi, muaiduts. kupi. - LINE, muaidutsi.

FIT, $v$. $t$, itski.

Frve, num: adj., kiliu.

FIx, $v$. $t$., kiksंe. - ER., $n .$, akukiksie.

FlaG, n., madakapilii.

FlaP, n., odakapilii, etadsiodakapilii.

Flat, $n$., amatsuka. - adj, tsuka. FLAY, v. t., daliipi.

Flee, $v$. $i$., kada [kara].

Fleet, adj., hita, hítạts.

Fleetry, adv., hita, hitaha.

Flesh, $n$., iduksiiti.

FloAt, v. $t$., dakapiliike, kidakapihike. $-v$. $i$, dakapilii, kidakapilii.

Floor, $n$, midatsuka.

Flour, $n$., kohatitapa.

Flower, n. and v. $i$. See Blos. solr.

FLY, $n$., maapoks̉a, maapuzi.

Fux, $\dot{v}$. $i$, kada, kide, kideakde.

FoaM, n., pulii. To CAUSE To puliike, kipuliike.

FoG, $n$., pue.

FogGr, $a d j$, pue, puekśa.

Fold, v. t., kipamudsi, pamudsi, patskupi, kidutskupi.

Fovd, adj., ohi.

FontaNEL, $n$., ikidutata, maikidutáta.
Future.

Food, $n$. , maduti.

Fool, $n$., madulita.

FOoT, $n$., itsi. - - PRINT, itsiti.

Forenead, n., ilii.

Forenoon, $n$., midimapedupahide.

Forest, $n$. , mida.

Forget, v. $t$., kidaliise.

Fork, n., aduśaṡa, aziicpus̉aśa, maipatsati, mika'idutsi, maipạ. kade.

Forked, adj., ṡaṡa.

Formerly, $a d v$., itsikadu.

ForT, n., alkumakikua ati.

ForTy, adj, topapitika.

ForwarD, $a d j$., $a d v$., itelia, itekoa. Four, num. adj., topa.

Fourth, num. adj., itopa.

Fourteen, num. adj., alipitopa.

Fox, $n$, ilioka. - BAND, n., iliokaicke. - сUB, iliokadaka. TRAP, iliokaitipe.

Fr $\triangle$ GILE, adj., pidalipa, tapai.

Fragrant, adj., iditsitsạki. .GRASS, matsuạtsa.

Freckled, adj., pulii.

Frenchman, n., masii, masii-ka'li. Fresh, adj., tsa.

Friend, n., See Comrade.

Frill, $v$. $t$, pidieke, kipidieke.

FRILlED, adj., pidie.

FrINGED, adj., dạliami.

FroG, $n$, s̉aaka, ṡaka.

Fruit, n., makata, matsu.

FRY, $v$. $t$, miditi.

Frying-PAN, n., maimiditi, idukṡitiomiditi.

Full, adj., maazi, kimaazi.

Fur, n., aduhi, bi, i.

FurRow, n., aduliakupi. - v.t.,

liakupihe, kiliakupike.

Furrowed, adj., liakupi.

Further, $a d v$., itaokadu, okadu, okakoa.

FuTURE. See duk, itakuahiduk, tieduk. 
GAIT.

\section{G.}

GaIt, n., odidi.

Gander, n., mída-kédapi.

G $\Delta$ RLIC, n., mika'uti.

Garmen'r, $n$, itulii.

Garnish, $v$. $t$., iptsi.

GAR.PIKE, n., muapahatski.

Garrulous, adj., idekșa.

Gather, $v$. t., hake.

Garter, n., idikedikśa, maidikedikșa.

GAZE, $v$. i., ika ka'ti.

GE', $\imath$. t., dutsi.

Ghost, n., dokidalii [nokidalii], idalif.

Gidxt, n., akubatski.

Girdee, n., maipasali. - v., kipaśaki, paśaki.

Girl, n., makadistamia, miakaza.

Give, $\imath$. t., ku, muk. - BACK, kikil.

GLaD, arj., da'tatsạki. - $-t . t$., kida'tatsạkike.

GLass, n., maikika.

GLEaM, $v$. $i$, itsitsi. - TO CAUSE To, $v . t$, itsitsike, kiitsitsike.

Glister, $v$. i., kaditska.

Globular, adj., poaduadsi, poadui.

Gloomr, adj., apaliitạtsi.

Glove, n., huki.

GluE, $n$., maikaditśkapa. - $v$., kikaditskapake.

Gluttos, n., akudútikșa.

Go, v., dakoa, de, koe, kada. oUT, atadi, kiatadi.

Gortre, n., dotictia [lotictia].

Gold, n., uetsa, uetsaka'ti.

Gore, part., dets.

GooD, adj., tsạki, tsakicti, tsạkits [sạkits].

Goodish, adj., tsạkadsi.

\section{HALT.}

Goose, n., mida. - BAND, midaicke.

Gosling, mídaidaka.

GRANDCHILD, n., itamapiśa (matamapis̉a, dítamapisa).

Grandfather, $n$, adutaka.

GraNDMo'THER, n., iku.

Grape, n., maśipisa. - VINE, masipisiaa.

GrASP, n., adalielii.

Grass, n., mika' [bika'], matsuatsa.

Gratis, adv., iśatsa.

Grave, n., dokteodusa amakoa.

Gravel, n., mi'kaza.

Grar, arlj., liota. - ish, liotișa. - BLANKET, n., t'̇eśa-masi. - HorsE, aku-hotais̉e.

Grease, $u$, tsada. - v., kitsadatsakike.

Greasi, adj., tsadatsaki.

GreEs, alj., mika'tohisa.

Grisv, v. t., pa, pi, kipa.

Groove, n., aduliakupi.

Ground, n., ama.

Grouse, $n .$, tsitska [sitska].

Grow, $r$. i., apadi. - v. t., apadike, kiapadike, okipadi.

Grows, part., apadike.

GuLlY, $n$., amadaktsaki.

Gư, n., maṡika, odusłkaśkapka.

GUN, n., midulia [bidulia]. - Pow. DER, midạtsapi [bidạtsapi].

Grpsum, n., madolia.

\section{H.}

HACK, $v$. $t$., dakạptsi.

HAIL, n., ma'kạlipıtami.

HAIR, n., ada, hi, i. - orr, atuitsati.

HALF, n., adj., itatsu, itatsuhe, tsu, tsuta.

HaLT, v. i., haka'ti. - imper., liaka'ta. - v. t., kiliaka'tike. 


\section{HALVE.}

HALVE, $v$. $i$., kidopake, tsutahe.

HAMMER, $n$., makidiki.

HAND, n., ișạki, saki.

HANDKERCHIEF, $n$., plietaisii.

HANDLE, n., hupa.

HANG, v. t., ikoki, kiikoki.

HAPPY, adj., da'ta.tsạki.

HARD, adj., tsatsuki, tsoki.

HARDEN, v. $t$.; tsatsukihe, tsatsukike, tsokike, kitsokike.

BARDE NING, part., tsokadui, kitsokadui.

HARE, n., itạki, itạks̉ipisà.

$\mathrm{H}_{\mathrm{AS}}, v$., matu.

Hasten, v. i., sidisii. - v. t., sidisisike, kis̈idisisike.

HAT, n., apoka.

HATCHET, $n$., maiptsadaka.

HATE, $v$. $t$., iku'pa.

HAw, $n$., mamua [mabua]. - TREE, mamuaa.

HAY, $n$., mika'udsi.

HE, pron., i, se.

HEAD, n., atu. - ACHE, atuade. - DRESS, apoka.

HEAL, $v . t$., kitsạkike.

HEAR, v. $t$., kikua.

HeART, n., da'ta [na'ta].

HEAT, n., maade, tsamak. - v.t., tsamehe [tsawehe], kitsameke, etc.

Heavens, $n$., apalii.

Heavy, adj., daktsia [naktsiats].

HeighteN, $v$. $t$., makuke, kimakuke.

HEP, pron., i, ita. Hers, itamae.

Heron, n., apitsatohi.

HICCOUGH, $v$. $i$., hatsakeki.

HIDE, v. t., alioa, ialioe. - n., odahipi.

HiGH, adj., maku.

Hill, n., amadia, amadeta, amamaku.

Hri, pron., i. - SELF, icki.

His, pron., ita, ita-mae.
INCLOSE.

HIT, v. t., diki; aate, kiaate.

HoE, $n$, amae. - OF BONE, hidúa-

mae. - of IRoN, úetsa-amae.

HoG, n., masiitadalipitsi.

HoLd, v. t., adalielii, ạkṡi, kiạks̉ie, optsati, oki.

HoLE, n., aduhopi, maaduhopi.

Hollow, adj., hopi, ho'pits.

Hourvy, n., makipa.

HoRs, n., azi, aziliami.

HoRse, n., itsuaṡuka, itaṡuka.

Hot, adj., tsame [tsawets], tsamekśa.

House, n., ati.

How, adv., tose. - LONG AGO, tuakisedu. - LONG HENCE tuakaduk. - MANY, tuami. MUCH, tuaka.

HowL, $v . i$, muadaki.

HUM, $v . i$, hoike.

HUNDRED, adj., pitikictia.

HUNGRY, adj., adiiti.

Hunt, v. $t$., kidi, kikidi.

HURRY, v. $i$, șidiši.

HURT, $v$., datạki.

Husband, n., kida, kidas.

Husk; n., hopatiisii, maisii.

\section{I.}

I, pron., ma, mi [wa, ba, wi, bi].

ICE, $n$., madulii.

ICICLE, $n$., madulii-icpu.

IGNORANT, $a d j ., v . i$, adaliise.

IlLUMINaTE, $v$. $t$., kiamaliatike.

Inıtate, $v . t$, kutski, ikutski.

IMITATOR, n., maikutskisia.

IyPORTUNe, $v$. $t$, kadiksंa, kikadi.

IMPOVERISH, $v$. $t$., kiadiasadsike.

IMPROVE, $v$. $t$., kitsakike, tsạkike.

IN, prep., amahoka, ka.

INcISE, $v$. $t$., idalipi.

INcisios, $n$., aduidalipi.

INCLOSE, $v$. t., kiamahókake. 
INCREASE.

INCREASE, $v$. $t$., kiahake, kiictiake.

INDENT, $v$. t., datạpi [latạpi].

INDIAN, n., amakadolipaka [amakanolipaka].

INFERIOR, adj., isia itaokadu.

INFIRM, $a d j$, itsíitats.

INFLATE, $v$. $t$., dakapnsike [nakapusiike], kidakapnsilke. - ED, dakapuse.

INGENIOUs, adj., kiadetsi.

INHALE, $v . t$, hi.

Irk, $n$. amašipisia.

INSECT, $n_{\text {., }}$ mapoksia.

INSIDE, n., amaho. - alj., amahoka.

INTERSECT, $v$. $t$., dumatitski.

INTOXICATE, $v$. $t$., moduliapake.

INVITE, $v$. $t$., kikuha.

IroN, n., uetsa, uetsašipisia.

IT, pron., i, sंe.

IтсHY, adj., liaka, lidia. - тo

MAKE, $v$. $t$., liakake, kiliukake, kiliidiake.

ITSELF, pron., icki.

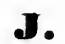

JAR, $v . t$., opsasa.

JeALOUS, adj, idikoamatu, miahtekșa [wialitekśa].

JEWEL, $n$., apoksia.

JINGLE, $v$. $i$., tsimua. - v. t., kitsimuake.

JoG, v. t., dapsiati [napsiati].

JorkT, n., adnsiuka.

JOURNEY, $n$., didi.

JUICE, n., adumidi.

\section{$\mathbf{K}$.}

KEEP, $v$. $t$., e. I WILL -, méwits.

KETTLE, $n$., midạha.
LATELY.

KEY, n., midéidnṡka, midiópeidaska.

KICK, v. t., adaliape, adape, kiadaliape.

KIDNEY, n., alioka.

KILL, v. t., ta, tahe, kitahe.

KInd, n., akn. What -? akuto?

KINDLE, $v$. $t$., kadalia.

KINDRED, n., itadolipaka.

KISS, n., ikidatsope, maikidatso-

pe. $-v$.t., ikidatsope, kidatsope.

KITCHeN., $n$, akumadiheati.

KitTen, $n$., puzikedaka.

KNEAD, $v$. $t$., dutsuki, kidutsuki.

KNEE, $n$, liualia, ilinalia.

KNIFE, $n$., maetsi [baetsi].

KNIFE-CASE, $n$., maetsiisi.

KNoCK, $v$. $t$, daktsuti.

KNow, v. t., eke. See $\uparrow 198$.

KNUCKLE, $n$., șakadusuki.

\section{L.}

LACERATE, v. t., adakạpe, dakạpi, kiadakạpe.

LADLE, $n$., azi, azidelie.

LAKE, $n$., midiictía.

LAuse, adj., odidi išia.

LAND, $n$., ama.

LAND-SLIDE, $n$., amadéta-tripíti, áma-tsipíti.

LANGUAGE, $n$., aduide, ide.

LAP, $n$., isuti.

LARDER, $n$. , madúti-adukiduṡá.

LARGE, adj., ictia,

LARIAT, n., iduti, matạlipi.

LARK, $n$., imạks̉idi [iwạks̉idi].

LAST, adj., ipita, ipitadu. - FALL, n., matáṡedu. - NIGHT, oktsisedu. - sumure, adesedu. WINTER, madasedu.

LATELY, $a d v$., tata, tatakoa. 


\section{LATHER.}

LATHer, $n$. See FoAM.

LAUGH, $v$. $i$, ka', ka'ks̉a.

$\mathrm{LAY}, v . t$, dușa, edede, liạpibe.

$\mathrm{L}_{\Delta Z \mathrm{ZY}}$, adj., da'taliepi [na'taliepi].

LEAF, $n$., midaapa, midápa [bida. pa].

LEAK, $v$. $i$, datskati [latskati].

LEAN, adj., liadalii. - $v$. i., ikalie, ipatạki.

LEFT, adj., idakiša. - SIDE, n., aduidakisia.

LEFT'HANDED PERson, n., maaduidakisia.

LEG, $n$, idiki. ForE-LEG, ada.

LEGEND, $n$., mazi.

LEGGINGS, $n$, itadsi.

Lengthen, $v$. $t$, hatskike, kihatskike, kimakule. - ING, part., hatskadui, kihatskadui.

Less, adv., itadotadu.

LEVEL, adj., tsuka.

LIAR, n., akumítapaksia.

Liberate, $v$. $t$., kabe.

LICK, $v$. $t$, datšipi [latsipi].

LID, $n$. iitipe.

Lie, $v$.. , See Decerve. - DOWN, liapi.

LIF', $x$. $t$, dubi.

LIGHT, n., amaliati. - adj, dakuliti, pidalipa.

Lighten, $v . t$., dakulitike [nakuh. tike], kidakulitike.

Lightwing, $n$., kadicka [karicka]. Ligrite, $n$., amaadalia.

LIKE, v. $t$., ite, kideta, kides̉adsi.

LIKE, adj., adv., kuișa, kuišadsi, kupi, mạks̉ese, sese. To MaKE 一, v. t., kimạks̉es̉eke, kuis̉ake, etc.

Lir, $n$., aputi, ideta.

LIQUEFY, $v . t$. , midike, kimidike. LIQUID, adj., miditsi [biditsi].

IIIQUOR AMNII, n., dakaadumidi.

LitTLE, adj., kadista [karisita], kadis̉tadi, kausta, kaustaalipi.

\section{MARry.}

LIVER, $n$., apiśa.

Lo, int, ika, ikaka.

Lock, n., matạliisìi. - v. t., kitsokike.

LODGE, n., amate', ati, atitsuahe. Lonesome, adj., liemi [liewi], liemikșa.

LoNG, adj., hatski. - $\Lambda$ Go, itsikakoa, mate, matekoa. - TIME, tia, tie.

LooK, $r$. t., ika. - BEHIND, ikipamidi. - THRougH, aktsesa, kiaktsisa.

LOOKING-GLASS, $n$., maikika.

Loosen, v. t., datsipi [latsipi], dusipi.

Lose, $v$. $t$., liạpihe, liapiheksia.

LOST, part., liạpi, liạpits.

Love, $v$. t., kidesii, kideta, ohi, ite.

Low, adj., padopi, padopidi.

LUKEWARM, adj., sakapi.

LUNGS, $n$., dalio [ualio].

Lysx, n., itupa, itupapuzi.

\section{I.}

Magic, $n$. See Mystery.

MAGPIE, $n$., icpe.

MAIDE乏, $n$, adukidadeṡa.

MaIZE, n., kohati.

MAKE, $v$. $t$, he, hidi, kiks்a.

MAKER, n., akuhidi.

MALE, $a d j$., adumatsé, adukedapi.

MALlet, n., maupạki, mi'maupạki.

Mamiary GLaND, $n$, a'tsi, antsi.

M $\Delta \mathrm{N}$, n., matse, itaka, sikaka.

MaNdan Indians, $n$, adalipakoa.

MANKIND, n., dolipaka [nolipaka].

MANY, adj., ahu.

MARE, $n$., mika, mikats.

MARRY, v. t., uahe, uaheke, kidahe. 
Marsh.

MARSH, $n$., maha.

MAssaCre, n., ditsi [nitsi].

MatCH, $n$., midahaidukąpi.

Mattress, n., uạkitạtsi.

ME, pron., mi [bi, wi].

Meal, $n$. See Feast. CornMEAL, holiatipi.

Measure, n., maikikisiki, maikutski. - $-v$. t., kikiski, kutski.

MEAT, n., iduka [iruka], iduksiiti, mahakakiski.

MEDICINE, $n$., hopadi.

MEET, $v$. $t$., itsauzie, uzia.

Melaxcholy, adj., liemiks̀a [hemi. ks่a!.

MEL'T, $v$. $t$, kimidike, midike.

Mend, $v . t$, kiksa, kitsạkike.

MENDER, n., akukikise.

Metal, n., uetsa.

METEOR, $n$., icka-pạti.

MIDDLE, $n$., dumata. - adj., adr., dumatadu. TOWARD THE - dumatakoa, dumatalia, dumatata.

MILK, n., a'tsimidi [a'tsibidi]. $v$. $t$, dutskipi.

MInIC, $n .$, maikutskiksंa.

Mrce, $x$. t., dakamitsi, kidakamitsi, kipamitsi, pamitsi.

Mrse, n., odutsi. - pron., matamae.

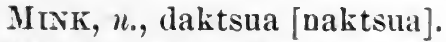

Minneconjou Indaxs, n., midikaoze.

Mint, $n$, hisua.

Minute, adj., tamulii [tawulii], ta. muliidi.

Miss, $v$. $t$., akitsa, kiakitsa.

Mitten, $n$. , liuti.

Moccasis, $n$. , hupa, itapa.

Model, n., ikutski, maikutski.

MoIsT, adj., adạtskui, adạtskuide.

Molasses, $n$., matsikóa-akutídue.

Money, n., uetsa.

Moos, n., midi [bidi], makumidi, óktsimidi. - FULL, midikakilii.

\section{NECK.}

- GibBous, midikakiliide. HALF, midiitatsu. See CRESCENT.

Moose, n., ăpătạpá (soft-nose.)

MoP, n., midatsuka idusuki.

Morvisg, n., ata, kiduhakute.

MoRRow, n., ataduk.

Mortar, n., maepe, mepi.

Mosquito, n.. apaka.

Mother, n., hidu, hu, huś, ikạ̇.

Mountain, n., amaliami.

Mours, v. i., imiạks̉a, kiimia.

Mouse, n., itahu.

Mouth, n., i. - of RIVER, azinti. Mow, $v$. t., itskiti.

MuCH, adj., ahu. So -, hidika.

Mucus, n., plieta.

MUD, n., tipia.

MUDDY, a., tipiatsaki.

MULE, $n$., apictia.

Vultiply, $r$. t., alıuke, kiahuke. MUsLIN, n., mašiiliiliapi.

Mr, pron., ma, mata.

MYSELF, pron., micki.

Mrsterious, adj., hopa.

Mrstery, n., hopadi, mahopa.

\section{N.}

NaIL, n., netsa-maictade, is̉ạkicpu, sakiicpu, itsiicpu. - v.t., daktalle.

NAye, n., dazi [uazi], odas่a'ti.

NARrow, adj., tsua, tsuadsi. $-v$. $t$., kitsuake, tsuake.

Nauseate, $v$. $t$., kikadéke.

Nauseated, adj., kade, kadeti.

NAVEL, n., itadelipa.

NEAR, ade., atsa, dota, utikoa.

NeARER, adv., dotadu [lotaru], itadotadu, itadotakoa.

NeARLY, adv. (suffix), de.

NECK, n., ampa. - LACE, maapi, maaliidulia. 


\section{NeEdLE.}

NEEDLE, $n$. matsito, adupatskadami.

Negro, $n$., maṡišipisia.

NEST, n., ikis̉i, tsakakaikisii.

NEw, adj., hida. A - THING, $n$., aduhida, maaduhida.

Next, adj. - suMmer, n., adeduk. - wiNTER, madaduk.

NIBBLE, $v . t$., datskạpi [latskạpi].

Nick, $n$. adudakaptsi. - v. $t$., dakạptsi.

NigHT, $n$. maku, oktsi.

NigHtLY, $a d v$., makudu, oktsiadu.

NINE, num. adj., duetsapi.

NinTH, num. adj., iduetsapi.

Nineteen, num. adj., alipiduetsapi [alipiluetsapi].

NinETy, num. adj., duetsapiapitika.

Nipple, $n$., a'tsiicpu.

No, adv., deša [neșạts].

NooN, n., midimapedupahi.

NorTH, n., adj., adv., amasita, amasitakoa.

NoRTHERN.LIGHT, $n$, apaliiadalia. Nose, $n$., apa. - BRIDGE OF, apaadusuka. - ROOT oF, apahedapi. - WING OF, apadaka.

NosTrIL, $n . ;$ apaaduhopi.

Not, $a d v$. , ta, tats.

Notch, $n ., v$. See NICK.

NothiNg, $n$., deṡa, maodeśa.

NumB, adj., otsliami.

Numeral, n., makidumi.

NuMERALS. See page -

NuRse, $v$. $i$. and t., a'tsihi, a'tsihike.

\section{(.)}

$\mathbf{0}$, int., $\mathrm{u}$.

OAK, n., midakamicka [bidakawicka].
OwN.

OAR, n., ilioki.

OBEse, adj., idipikṡa.

Obliquely, $a d v$., dumilia.

Obtain, v. $t$., dutse [rutse], dutsi.

OCHRE, $n$., amatsidi.

ODOR, n., aduiditsi, maaduiditsi, maiditsi.

ODORATE, $v$. $t$., iditsike, kiiditsike.

ODorous, adj., iditsi, iditsi matu.

OFFICER, n., akumakikúa-matseétsi.

OrL, n., tsada. - v. t., kiitsatike.

OLD, adj., lie, liie. - MAN, n., itakalie.

ON, prep., adv., aka.

ONCE, adv., iduétsadu.

OrE, $n .$, adj., duetsa [luetsa].

ONION, $n$., mika'uti [bika'uti].

ONLy, adv., ta, tats.

Open, $v$. t., dusisipi, duṡke, kiduṡipi.

OPPOSE, $v$. $t$, mạkia, kimạkia.

Opposite, $a d v .$, kuplieda.

ORANGE-COLORED, adj., tsidadsi.

ORDER, $v . t$., iské.

ORDURE, $n$. , adnedi, pedi.

ORION, $n$., ickadami.

OrnaMent, $v$. $t$, kipudsi, kipudsike, kipuzike, mamadaki, pudsi, pudsike.

OTHER, adj., iha, ihats.

OTTER, n., midapóka [bidapoka].

OUR, pron., mata. OURs, matamae.

OURSELVES, pron., midoki [wiroki].

Out, adv., atazikoa. To Go $v$., atadi.

OUTSIDE, n., atazi.

OUTWARD, $a d v$., atazilia.

OVER, prep., adv., akoka, hakoka.

Overturn, v. $t$., kipa'te, pa'te.

OwL, n., hute, itákupe.

Ows, adj., mae, itamae. 


\section{PADLOCK.}

\section{P.}

PADlock, $n$., matạliiisa.

PAD-SADDLE, n., matạtsidalioke.

PaIN, v. i., ade. - v. t., adeke, kiadeke.

Paint, n., ui. - v. t., madaki.

Painting, n., mamadaki.

Palate, n., akata.

Pale, adj., iliotaki, oliati.

Palisade, $n$., midạkís.

Pax, n., midạksii. See FryingPAN.

Pantaloons, n., itadsi, maśíitadsi.

Parch, v. $t$., adaliake, kiadaliake, liadapapilie.

Parched, part., aclalia.

Pare, $v$. t., datskipi [latskipi].

Parflêche, n., dalipitsoki.

Parflêche-case, $n$., mạkiisi.

Part, n., adạlipi, haustalipi, maadạlipi, tsu, tsuta, tsutaka.

Pass, v. t., itsauzie, mạkiniakada. ha, mạkimakadahatidie, oda.

Paste, n., maikaditskapa. - $v$.t., kikaditskapake.

Path, n., adi [ari].

Paunch, n., kilia.

Pawnee Indians, $n$. , tśeśadolipaka.

PEA, n., amazi.

Pebble, n., mi'kaza.

PEG, n., maictade.

Pelicax, n., apasaki.

Pelt, n., dalipi, odalipi.

PEN, n., úetsa-maíakakạsi.

PexcIL, n., maiakakași, maimadaki.

Pendant, n., maitsimua.

People, n., dolipaka.

Perforate, $v$. $t$., hopike, kihopike.

\section{PoKE.}

Perforated, adj., ho'pi, hopits.

Perfume, n., aduiditsitsạki, maaduiditsitsaki.

Perspire, v. i., tsameate (tsaweatels.)

Persuade, $v$. t., kadạtsike (karạtsike), kikadatsike.

Pestle, n., maepaka, mepaka.

Petrify, $v$. $t$., kinu'ke.

Phlox, n., pedetskaitaạipiśa.

Phrsicrax, n., masí-hopa, matsehopa.

PICK, $v$. t., kidakapi.

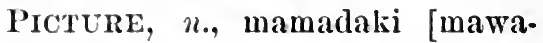
daki.]

Prece, $n$. adạlipi.

Prllow, n., dalikisii, ódaks̉isi.

PILlow·Case, $n$, dalikisisi [nalikisisi].

Prs, n., matsito-utipoadui.

Pixcers, n., maidutskapi.

Prx̃ch, v.t., datskạpi, dutskapi.

Pwe, n., maatsi, matsi.

Prxк, adj., hisi-ámabu.liota.

Pipe, n., ikipi. - sten, ikipihu-

pa.

Pitchfork, n., mika'idutsi.

Place, n., kuadu, selu (I I 47, $50)$. $-x \cdot t$., kiamabokake, kidusa, patạki.

Plais, u., teluti [terútiṡ].

Plaxt, v. t., amaoze. - n., a, maa.

Plate, n., matạki.

Plar, $v$. i., mạkia, midaliaticke.

Playing-cards, n., maimạkieke, masiitaimạkieke.

Pleiades, $n$., ickalialiua.

Pluck, $\imath$. $t$., dukiti, kidukiti.

Plum, n., makata. - TREE, ma. kataa.

Plunie, n., matslioki, oki.

Point, n., icpu.

Poison-vine, n., mailiaka.

PoKE, v. t., dutati. 


\section{Polish.}

PoḷISH, v.t., kitsatike, tsatike.

n., maikitsatike.

Pomme-Blanche, $n$., ahi'.

Poor, adj., adiaṡadsi, liadalii.

PoPGUN, 16., miduliake.

Poplar, n., midahádsi-pạkpạksisi.

Popliteal SPACE, $n$., idikalia.

Porcupine, n., apadi. - QUILLS, apadihi.

Post, n., atutikoaiptsa, aduiptsi, iptsa, iptsi.

Poт, n., midạlia [bidalia].

Potato, n., kaks̉a, maíitakakśa.

Pouch, $n$., is̉i, opeisii.

Pour, $v$. $t$, paline, katike.

PowDER, n., midạtsapi. - HORN, midạtsapiisi.

Prairie, n., amaadatsa, teduti.

Prairie-hen, $n$., tsitska [sitska].

Pregnant, adj., edi-ictía.

Presently, adv., itekoahi, itekoa. hiduk.

Press, v. t., datati, dutạpi, dutskapi.

Pretty, adj., ite, tsạki.

PrICE, n., imasii.

PrickLy, adj., liahia.

Prickly PEAR, n., patskidia.

Protrude, vo. t., kiptsuti, ptsuti.

Psoralea, n., ahi', ahi'mika.

Pull, $v$. $t$., dukidi.

Puma, n., itupaictia.

PUMPKIN, n., kakui-ictía.

Punch, $v$. $t$, patskapi.

Puncture, v. t., kipạkade, pakade.

PUPIL, $n$., ișta-adusipis̉a.

PuP, n., maśuakaza.

Purulent, adj, itudi.

PusH, $v$. $t$., adakide, pạkide, kiadakide.
REED.

QUARTER, $n$., adukitopake. - $v$.

$t$., kitopaheke, topaheke, topake.

Quench, v. t., kạtsi.

QuICK, adj., hatatạki, sidisisi.

QUICKEN, $v$. $t$., sidisike.

QUIET, $v$., tsạkihamak.

Quill, $n$., apadi, apadihi, is่u, ka-

mickisiu, matslioki, oki.

QUIVER, n., maitaisisi.

\section{R.}

RABBIT, $n$. , itạki, itạks̉ipis̉a.

RACE, $v . t$, tidieke, mạkiatidieke.

RAIN, $n ., v$, liade, liadets.

RAINBOW, $n$., midiapoka.

RAISE, $v$. $t$., duhi, kidubi.

RAISIN, $n$. , maśipis̀a.

RAKE, n., maikiduliadi. - v. t., kiduliade.

RANCID, adj., puade.

RAPID, adj., liatatạki.

RAPIDLY, $a d v$., liatatạka, liatatạkaha.

RAT, n., itahuictia.

RatTle, $v$. $i$, liamua [habua]. -

$v$. t., liamuake, kiliamuake.

RATTIESNAKE, n., adutsidiamatu.

RAVEN, $n$., adis̉a, pedetska.

RAVINE, $n$, amadaktsaki, amaaduliakupi, datipi.

RAw, adj., tsa. - HIDE, $u$. See PARFLÊCHE.

RAZE, v. t., dutsiti [rutsiti], kidutsiti.

RAzoR, $n$, maídakakiti.

ReceptaCle, $n$., ioki, iope isii, ma-

ioki, maiope, maisii.

RED, adj., hisi.

REDDISH, adj., his̉adsi, hisisisi.

REDDEN, v. $t$., hisike, kihisiike.

REDDENING, part., kihisisiadui.

REED, $n$., pupu.

Quadrangle, n., adupạhi-topa. 


\section{REFLECTION.}

REFleCtron, $n$., idaliihi.

REFUSE, $v$. $t$, itsa.

RELATION, $n$., itadolipaka.

Release, $v$. $t$, duṡa, dusie, kahe.

REMEYBER, $v$. $i$, kạdami, kikạdami.

REMiNd, v. $t$., kạdamike, kikạda. mike.

REPTILE, $n$. , mapoks๋a.

Reseyble, $v$. $t$., kike. See Alike.

REsolute, adj., da'tatsoki (na'tatsoki).

RETURN, v. t., kiku.

RIB, $n$. , duta.

RibBoN, $n$., mapidalipa.

RIDdLE, $v, t$, kiho'pike.

RIDE, v. t., kidie, kidumahitatidie.

Ridicule, $v$. $t$., nati, uatiksa.

Right, n., idapa. - adv., idapalia, idapakoa.

Rivd, $n$, aduaka, aduisi.

RiNG, $n$. See FINGER.RING. $v$. $i$., tamua.

RIPE, adj., oti. - v.t., kiotike, otihe, otike.

RISE, $v$. $i$, ate, iduhi.

River, n., azi. See Mouth and Source.

RoAD, n., adi.

ROAST, $v$. $t$., hatsite.

RoBE, n., dalipi, itaṡi, mas̉i, miteodalipi.

Rоск, $n$. , mi'.

Rock, v. t., dakudsi, liakahe, kidakudsi.

RoIL, $v$. $t$., midisake.

RoLL, v. t., dumudsi, pamudsi ; ka. ki ; ukaki.

Roof, $n$. , atidutidu.

Root, $n$., uti.

Rops, $n$., as்u, matạlipi.

Rose, n., mitskapa. - BUSH, mitskapaa. - FLOWER, mitska. paodakapaki.

RotTen, adj,, pua, puats.
ScORCH.

ROUGE, $n$., iteui.

ROUND, adj., kakilii. - NEARLY,

kakihide. - TO MAKE, v., ka-

kiliike, kikakihike.

Rouse, $v$. $t$., itsihe.

Row, $v$. i., lioki (malioki, dalioki).

Row, n. Is A -, daktsike, kidaktsike.

RuB, v. t., kipạkisi, kipalitue.

Ruffle, $n$. , adupidie. - $a d j .$, pi-

die. - v. t., pidieke, kipidieke.

RUMes, n., kiliaadupidalipa.

Ruv, $v$. $i$, tidie, mạkiatidie.

SACRED, adj., hopa, hopáts.

SAD, adj., liemiksa.

SADDLE, n., dalioke.

SAGE, n., iliokataki, uliimaduti.

SAGE-HEx, $n$., tsitskaictia.

Saleratus's, $n$., madạliapiikida kapusi.

SALT, n., amaliota.

SAND, n., puliaki. - BAR, puliạki-

ate.

SAPLING, $n$. aduokipadi.

Satiate, $v$. $t .$, , liạpatike, kiliạpa-

SATISFY, $v, t .$,$\} tike.$

Satiated, liapati, liapatiksa.

Saturate, $x . t$., kiadạtskuike.

SAW, n., midiíapati.

SAl, $x$. t., ide, heduts, heidekime.

Scabbard, n., midiisisisi.

SCALD, $v$. $t$., otihe.

SCALDED, part., oti, otits.

SCAR, n., adueta [erueta].

SCARED, adj., liopạsi.

Scarlet, adj., hisi, hisi-ká'ti.

Scent, $n$., aduiditsi, aduiditsitsạki,

akuiditsitsạki. - v. t., iditsike,

iditsitsạkike, kiiditsitsạkike.

ScIssors, $n$, maitskiti.

ScORCH, $v$. t., adapapi, adapapike. 


\section{SCRAPE.}

ScRAPE, $v$. t., hatsa, kidakakiti. Scratch, v. $t$., kae, ke, kike ; adakạpi.

SEAM, $n$., adukikaki.

SEason, $n_{.}$, kadu. In A -, adv., kadudu.

SEAT, $v$. $t$, amakike, kiamakike.

SECOND, adj., idopa.

SECondly, adv., idopadu.

SEE, v. t., ika (I 201), ąktsisa-.

SEED, $n$. , adutsua.

SEEK, v. t., kidi, kikidi.

SEIzE, $v . t$., adaliehi.

SERVICE-BERRY, $n$., matsutapa.

SET, v. i., imalipi.

SEver, adj., s̉apua. - TH, is̉apua. Seventeen, adj., alipisiapua.

Seventy, adj., sapuapitika.

SEver, v. t., adatsạki, dutsạki.

SEW, v. t., kikaki.

ShabBY, adj., kuti.

SHAD-BUSH, n., matsutạpaa.

SHAdE, $n$. , dalii, daliilii. - $v$., aduoktsihe.

SHADOW, n., aduoktsi.

SHAKE, v. $t$., liakahe; adato'ti, dakato'ti, 'kiadato'ti, kipato'ti, etc.

Shallow, adj., liepi, liepiks̉a.

Shajie, $v$. $t$, itạdike, kiitodike.

SHarp, adj., sptse.

Shave, $v . t$., dakakiti, kidakakiti. SHAWL, $n$., mas̉idạliami.

SHe, pron., i, sंe.

Shear, $v$. $t$., datskiti.

Shell, $v$. $t$., daṡie, daliade.

SheEP, $n$. See BIGHORN.

SHIELD, $n$. , midaki.

SHINe, $v$. $i$, amaliati, kaditska.

SHIRT, $n$. , matsé-itulii.

Shiver, $v$. $i$, dada.

ShodL, n., aduliepi, maaduliepi.

ShoE, $n$. , hupa, itapa.

Sноот, v., di, tadatodi, ualipi.

SHORE, $n$., midideta.
SLOW.

SHort, adj., padui, padopi, pado. pidi.

Shorten, $v$. $t$., paduike, kipaduike. SHortenivg, part., paduadui, kipadopadui.

SHot, $n$., adupóadui-kadísta.

SHOULDER, n., idạspa.

SHOULDER, $v$. $i$, idas̉pakipe.

SHove, v. $t$. , kipkidi, kiptsuti, pakidi.

SHOVEL, $n$, amaidạiisie.

SHow, v. t., atehe, ateheke.

SHUT, $v$. $t$., kipatạki, mạkipatạki. SICK, adj., ilioade.

SidE, $n$., adupatska, tsu, tsuta.

SigH, $v$. $i$, idialii, kiidialii.

Silver, n., uetsailiótaki.

SINEW, n., matsua, matsuapạkisi. Sing, $v$. $i$., pahi, kipahi.

SrvK, v. i., tsipi. - v. t., tsipike, kitsipike.

StRIUS, n., ickadehi.

Sister, ., idu, iku, itakisa, itaku, itamia. - IN.LAW, naka.

SIT, $v . i$, amaki, kiamaki.

SIx, num: adj., akama.

Srxth, iakama.

SIXTEEN, adj., alipiakama.

SIXTY, adj, akamaapitika.

SKate, n., maidaktsadake. $-v$.

$i$. , daktsadake.

SKEWER, $n$., maipatsa'ti.

SKIFF, n., midamati.

Skin, n. See Pelt and Robe.

SkUll, n., atúhidu.

SKUNK, n., lioka.

SKY, n., apalii.

SLED, n., maidutsada, midamaidutsada.

SleeP, v. t., hami, hamiksia, hidami.

SleEPy, adj., hamicti, hidamicti, hiolioi.

SLIDE, $v$. $i$, dutsada, kidutsada.

SLow, adj., ṡua. 


\section{SLOWLY.}

Slowly, adv., hopa, sua, suaha.

SMaCK, $v$., datsope.

Small. See Litrle. - Pox, maliaka.

SyarT, $v$. $i$, has̉isii, kihasisisi.

Syash, $v . t$., dakata [nakata], ualipi.

Syell, $n$. , maaduiditsi, maiditsi. - v. t., mupi. - v. i., iditsi.

Suroke, $n ., v . i .$, pie, pieksia. - $v$. $t$., opehi.

Smooth, adj., tsutsute. - v. t., kipkite, kitsutsutike, pakiti.

Suootming-IRoN, n., maikipkiti, maituliiikipkiti.

SxaG, n., midaicpati.

SNAIL, n., maišpadumidi.

SxaKe, n., mapokșa.

Sxap, $v$. $i$., adatạlipe.

Sxeeze, $v$. i., halipi, kihalipi.

SNow, $n$. , ma'podetskistapedi.

$v$. $i$, ma'pi, ma'pits.

Sxow.BIRD, n., madadaka.

Sxuff, $n$., maihalipi.

SoAP, n., maitidusuki [maitirusuli.]

Sockét, n., ioki, maióki.

SoFT, adj., tapd.

Softex, $v$. $t$., tapake.

SoIL, $v$. $t$., kiawatsakike, kiiliatsa-

kike, kitsadatsakike, etc.

Solled, adj. See Dir'Ty.

Soldme, n., akumakikua, masi". akumakikúa.

Soṿ, $n$., idisii.

Soxg, n., makipahi.

Soon, adr., itelsoahiduk.

SorE. See Scar. $-v$. i., ade, hasisisi.

Soup, n., hupa.

Sour, adj., adui. - $-v$.t., aduike.

SOURCE, n., aziicpu.

SouTH, n., adv., umata, umatalia, umatakoa, umatata.

Sow, v. t., amaoze.
Stomach.

Spavi, n., itakidakahe, sakiitakidakahe.

SpaN, $v$. $t$., kidakahe.

SPILL, $v$. $t$., adaliu, liu, paliue.

SPIRIT, $n$., dalii, idalii, dokidalii.

SPIT, $v$., aksंue, kiakśe, sue.

SPoILIYG, part., isiadui, kiisiadui.

SPoNGE, n., midiidaliupi, maimidi-

pike.

Spool, u., midaiapi.

Spoox, n., azi, azidelii, azis̉ipis̉a, azinetsa.

SPOTTED, adj., puzi.

Spre $4 \mathrm{D}, v$. t., dakahe, kidulia.

SPRING, n., maha.

SPrixg, $v$. $i$, dutsisii, kidutsisi.

Sprivile, $v$. $t$., duto'ti, kiduto'ti.

Sprout, n., aduisamike. $-v$. $i$., apadi, ișamike.

Square, $u$., adupaliitopa.

SQUAw, n., mia, amakadolipáka-

mia.

Squeal, $r$. $i$., dạki [nạki].

SqueEze, $v$. t., datati, datạpi, dutskapi, dutskati, kidatati, kilatạpi, kidutsati.

SQUINT-EIED, adj., istaduta.

SquinT, $x$. $t$., datskati.

Stuis, $v$. t. See Soll.

StaR, n., icka.

Starve, $v$. t., kiadiitike, kiliada-

like, kiliadaliiksake.

Steal, $v$. $t$., aśadi.

Steayr, $v$. $i$, pue. - BoAT, matisișal.

STEEP, adj., daliạpeṡi.

STEN, $n$., aduhúpa, hupa.

S'́feNCH, $n$., aduiditsiisia.

Sternuj, $n$., imạkidu.

STICK, $n$. , midakaza. $-v$. $t$., datsa'ti, kidatsa'ti, kipạkade, pạka. de, patsa'ti. See ADHERE.

Stixg, v. t., hasisisike, kihas̉išike.

S'muN, $v$. $i$, iditsiisia.

STOMraCH, n., kilia. 


\section{STONE.}

Stone, n., mi', mi'kaza.

SToP, v., haka'ta, liaka'tibe, kiliaka'tike, opsiaśa.

Stopple, $n$., iapạti, maiapạti.

STove, $n$., úetsa-aduua.

STORE, v. $t$., kidusa.

STore-Roou, n., adukidusa, maadukidusia.

Straight, adj., tsamutsi [tsawutsi].

Straighten, $v$. t., tsamutsike, tsamutsihe, kitsamutsike. - ING, part., tsamutsadui.

STRANGLE, $v$. $t$., dutskiti.

S'TRAWBERRY, n., amaalioka.

Strengthen, $v$. $t$., itsiike, kiitsiike.

STRIKE, v. $t$., diki.

STRIPE, $v$. $t$., lialiike, kilialiike, kipuzike, puzike.

STRIPED, adj., puzi.

Strong, $a d j$., itsii, itsiits.

Strouding, n., akuhisisi.

STURGEON, n., muapadelii.

SUBordinate, $n$. , maiske.

Suck, v. $t$., a'tsibi, datsuki.

SuCKLE, $v$. $t$., a'tsihike.

SUGar, n., matsikoa ( $f r$. tsikoa).

Sultry, adj., adekṡa.

Summer, $n$., ade, maade.

Sun, n., midi [bidi], mapemidi.

— RISE, midiate. - SET, midiimalipi.

SundaY, $n_{\text {, }}$ mapehopa.

SuNFISH, $n$., muatsuka.

SupPort, $v . t$., ạksie, kiạks̉ie, oki.

SurfeIT, $v$. $t$., kiliapạtike, kiliapatiksake.

Surround, v. $t$, ialialia, oki, optsati.

SURVEY, v. $t$., ama kikiški.

SWALLOW, n., amaśodisia.

SWALLOW, $v . t .$, , kipe, pe.

SwEeP, $v$. $t$., masialia.

SwEET, adj., tsikoa.
'Ten.

SWEETEx, v. t., ketsikoake, tsiko. ake.

SWELL, $v$. i., kipuake, puadui.

Swell, to CaUSE To, $v$. $t$., kipuake, puake.

Swelling, n., adupua. - part., kipuadui, puadui.

Swru, $v$. $i$, midididi [bidiniri].

SwING, n., maikidakudsi. - $v . t$., dakudsi, kidakudsi.

Swollev, adj., pua, puạts, katsuka. SWORD, $n$, midiisi.

SYRINGE, $n_{.}$, maidatskati.

\section{T.}

TAlL, n., icpe, tsita.

TAINTED, adj., puade.

TAKE, $v$. t., dutse, kidutse, kuts.

- BACK, kudsi. - Dows, du. lipi, kidulipi.

TALE, n., mazi.

TALK, $n$., aduide, ide. $-v$. $i$. , ide. TALL, adj., hatski, maku.

TALLY, $v . i$, dakaptsihe [nakaptside].

TANGLED, adj., sikia, sipe.

TAPERING, adj., tsohi, tshuahe.

TASsel, n., okiicpu.

TASTE, $v$. $t$, kikiški.

TaTTOO, $v . t$, pi, kipi.

Tatrooris, n., pi, adupi.

TAWNY, adj, sidi. - TO MAKE, $v$. $t$., sidike, kisidike.

TEA, n., midapa [bidapa].

TEar, v. t., adaliese, daliese [la-], duliese, dukạpi, kiadaliese, kidu. liese, etc.

Tears, n., istamida.

Tediously, $a d v$., hopa.

TELL, $v$. $t$, kime.

TEMPLE, $n$., atihopá.

Ten, num.adj., pitika. Tenth,ipitika. 
Tenthly.

Tenthly, $a d v$., ipitikadu.

'Tendos, n., akazi.

TENT, n., atitsuathe, maśiliii ati.

TEPID, adj., sakapi. - TO MaKE, sakapike.

TERrIFIED, part., hopạsi, kihopạsi.

Terrify, $v$. $t$., hopạsike, kihopạsi. ke.

That, pron., hido, kin, kua, kutsạ. ki, se, ṡetsạki.

THEe, pron., di [ni].

THEFT, $n$, maasadi.

Theirs, pron., itamae. See $\uparrow 122$.

Themselves, pron., hidoki.

Thes, adr., sedu [seru].

There, adr., hiduka, kuadu, sedu, sekoa. - ARE, $v$., matu.

THICK, adj., tạtsi, titsi, titsikśa.

Thickes, $v$. ., tạtsike, titsike, ki. tạtsike, kititsike.

Thichening, part., tạtsadui, titsadui, kitạtsadui, kititsadui.

Thickish, adj., tạtsadsi.

Thrs, adj., liapi ; liadalii.

Thisk, $v$. $i$ and $t$., idie.

Trind, num. adj., idami [inawi].

Thinstry, arjj., udsi.

ThirTY, num. adj., damiapitika.

Thirtees, num. adj., alipidami.

THIs, pron., hidi. - ycCH, adv., hidika, hidikats. - PLACE, hidikoa.

Thou, pron., da, di.

Thousaxd, mum. adj., pitikictiaakakodi.

THREAD, $n$, maikikaki.

Three, mum. adj., dami [nawi].

Throat, n., doti [loti].

Through, prep., adv., dumatadu.

Throw, $v$. $t$., ise, kipạtike, pạtihe.

Thuмв, $n$, sakita.

Thunder, n., tahu, tahuidaka.

Thus, adv., hidise, kua.

TICK, n., uạkitạtsi.

TICKLE, $v . t$, șasukibe.
Twenty.

TIE, $v . t$, dutskiti.

TIRE, $v$. t., dabika'tike, kidahika'tike.

Trked, adj., daheha'ti.

To, prep., lia, ka.

Tobacco, n., ope. - BaG, opeisi.

TO-DAY, n., adv., hídi-mape.

TOE, n., itsiadutsamihe.

Together, adv., apika, ikupa.

To.Mornow, $n ., a d v$., ataduk [ataruk].

Toxgue, $n$, dezi.

To-NigHT, n., hidi.oktsi, makuduk, oktsiadnk.

Tooth, n., i, is̀a, hi.

Tor, n., icpu.

Toks, part., daheṡi, duliése, pakạpé.

Toss, $v$. t., liamike, kiliamike.

To'TEy, n., daki.

TotGH, adj., kamicka.

Toward, mep., lia, ta, dotalia.

Towel, n., maikipakisisi. See $\uparrow 44$.

Trade, $r$. $i$. See Bur.

Trader, n., akumaíhu.

Trail, $n$., adi.

TraMr, $x$. $i$, dakatạlii.

Trample, $v$. $t$., adatapi, adatehe.

Transparent, adj., delii.

Trap, n., itipe, maitipe, maikiku.

Travelling-Party, $n$, dadi.

Trejible, $v$. $i$. See Shiver.

Triasgle, $n$., adupạliidami.

Truly, adv., ka'ti.

TRY, $v . t$., maihe [waihe].

TUBER, n., kaksia.

Tuck, $v$. $t$., opaṡa, opas่aku.

Tuyror, n., adupua.

TURBID, adj., midisia.

Turs, v. t., dumidi, dumilia, kạtake.

TurNip, n., ahi'.

TUR'TLE, $n$. , matạlii.

TWELve, num. adj., alipidopa.

TwEstr, num. adj., dopapitika. 
Twice.

Twree, adv., dopa, dopatsakoa.

Twilight, $n$., ha'pesede.

TwinkeE, $v$. i., kaditska.

TwIN, $n$., dakadutska [nakalu-].

TwIST, $v$. t., adamidi, dumidi, kidumidi, pamidi.

Two, num. adj., dopa [nópạts].

\section{U.}

UDDER, n., a'tsi.

UGLY, adj., išia, iteišia.

UNCLE, n., ate, itadu.

UNDER, prep., miktakoa [wikta-].

UNDERSTAND, $v . t$., eke.

UNFOLD, v. $t$. , dakatihe.

UNI'TE, $v$. $t$., kiikupake, kiduétsake.

UnTıE, v. t., dasiipi, dusipi, dutṡipi, kidutsipi.

UPLAND, $n$., amaadatsa.

UpoN, prep. adv., akoka.

UPRIGHT, $n$., aduiptsi.

UPSET, $v$. $t$., adaline, line.

URSA MaJor, n., ickaśapua.

Us, pron., mido [miro, wido].

\section{$\mathbf{V}$.}

VALLEY, $n .$, amaliakupi.

VALUE, $n$., imasii.

VAPOR, $n$. , pue.

VARNISH, $n$., maikitsatike.

VENison, $n$., tsitatạki iduksiti.

Vexus, $n$., ickaictia.

Vermilion, $n$. , ui, iteui.

VERY, adv., ka'ti.

VEST, n., mapatópe.

Village, $n$., ati, ati ahu.

VINE, n., masiipisaa.

VIoLIN, $n$., maśíitamakipahi.

VIRGINIA CREePER, n., mahopamiaitamatsua.

VISIT, $v$. $t$., uzie, kiuzie, midedi.
WHISKEY.

Vonit, v. $i$. , kade.

Voracious, adj., adiítikśa.

\section{W.}

WAGON, n., midaikaki.

WAIST, $n$., hedapi.

WAIT, $v$. $i$, haka'ta.

WAKEN, $v$. $t$., itsihe.

WaLK, $v$. $i$, dide. See GaIT.

WAR, $n$, makimạkia.

WiRIr, $a d j$. ade, tsame.

WAR-PARTY, n., matsedidi.

WARPING, part., kis̉akupadui, śakupadui.

WARRIOR, n., akumakikua.

W $\Delta$ SH, $v$. $t$., dus̉uki, dutskisii, kidusuke, kidutskisi.

WASHING, $n$. , makidutskisii.

WASP, $n$., mapatskakiditi.

WАTCH, n., midiikikiski [bidi-].

WATER, n., midi. - v.t., midihike.

WATERY, adj., millitsi.

WAVE, n., mididạ́hisisi [bididạliisii].

WaVE, $v$. $t$., pato'ti.

WE, pron., ma, mi, mido, midoki.

WEARILY, adv., hopa.

WEASEL, $n$., utsitsa.

WED, v. $t$., uahe.

WEDGE, n., mitsi.

WEEP, $v$. $i$., imia, is̀tamidi pạti.

WEIGH, $v$. $t$, kikiski.

WEIGHT, $n$. , maikikis̉ki.

WELL, adv., tsakihe.

WEST, $n ., a d j ., a d v$. , patsati, patsatikoa. - WARD, patsatilia.

WET, adj., adạtskui. - v. t., adạ. tskuike, kiadatskuike.

WHAT, pron., tapa, taka, takada, to.

When, adv., tuakaduk, tuakasedu.

WHERE, adv., to, todu [toru], toka.

WHICH, pron., tapa, tape.

WHIP, n., iki. - v., diki.

WHISKEY, n., midiadui [bidialui]. 


\section{WIIISPER.}

WHISPER, $v$. i., tsitside.

Whistle, $n$, ikozi. - $-v$. kozi.

WHITE, adj., ataki, ihotaki, oliati.

- MaN, $n$., masii.

Whiten, $v$. $t$., iliotạkike, kiatạkike, etc.

WHITE-WASH, $n$., atiipkiti.

WhiтHER, adv., tapata, toka, tokta, tota.

Wно, pron., tape.

WhоLе, adj., liakaheta.

Whose, pron., tapeta, tupeita, tapéitamae.

WHY, adv., tosie.

WIDE, adj., soki.

WIFE, n., itadamia, ua.

WILD, adj., idapudi.

WiLlow, n., maliuliisa, midahadsi.

WIND, n., hutsi.

WINDOW, $n$, maikika.

Wing, n., icpa.

WINk, $v$. $i$., istaliulii.

Winter, n., mada, tsidie. see LAST and NEXT.

Wırh, prep., api, apika, ikupa.

WoLF, $n$., motsa [botsa], tśeșa.

WoLf-BERRY, $n$., mas̉ukaakśu.

WoMran, $n$., mia, miakaza.

WooD, $n$., midla [bida].

WORK, $v$, dahe, kiksia.

WoRM, n., hupaakuikutski, mapoks̉a.

WoRMWOOD, n., iliokatạki-akusipis̉a.
Yourselves.

WorSE, adj., isiia-itaókakoa.

Wound, $n$., aduu, aduakṡąki, oda.

ks̉ake. - $-v . t$., u, dakșaki, duka-

pi, idahipi, kidakṡaki, kidukạpi.

WraP, v. $t$., pudsike.

WRINKLE, v. t., liipike, kiliipike.

WRINKLED, adj., hipi, hipits.

WRIST, n., ikuti.

WRITE, v. i., ạkakạsi.

WRITING, n., maạkakạsii.

\section{$\mathbf{Y}$}

YARDSTICK, $n$., maikutski.

YAWL, n., mirlamati.

$\mathrm{Y} A \mathrm{WN}, v$, $i$, ida.

$\mathrm{YE}$, pron., dido [niro].

YeAR, n., mada. See WINTER.

YEAST, n., maahapiikidakapusii.

YELLOW, adj., tsi, tsidi. - ISH, tsidadsi. - DYE, n., itsidike. - TO MaKE, v., kitsidike, tsidi. ke. - TURNING To, tsidadui.

YEs, adv., e, hao.

YesterdaY, n., húdisiedu.

YONDER, adv, oka.

You, pron., da, di [na, ni].

YouxG, $n$., daka, idaka. MAN,

sikaka. - Woyan, miakaza.

Your, pron., di, dita.

Yours, pron., ditamae [nitawaets].

YouRSELF, pron., dicki.

YouRSELVES, pron., didoki. 






